INSTITUTO DE PESQUISAS ENERGÉTICAS E NUCLEARES AUTARQUIA ASSOCIADA À UNIVERSIDADE DE SÃO PAULO

SÍNTESE, PROCESSAMENTO E CARACTERIZAÇÃO DE CÁTODO PARA APLICAÇÃO EM CÉLULAS A COMBUSTÍVEL DE ÓXIDO SÓLIDO DE TEMPERATURA INTERMEDIÁRIA

REINALDO AZEVEDO VARGAS

Tese apresentada como parte dos requisitos para obtenção do Grau de Doutor em Ciências na Área de Tecnologia Nuclear - Materiais

Orientadora:

Dra. Emília Satoshi Miyamaru Seo

SÃO PAULO 
Dedico este trabalho ao meu pai Francisco Vargas Maldonado Filho, à minha mãe Lizete Azevedo e ao meu irmão Renato Azevedo Vargas, por tudo que significam e por todos os valores que me ensinaram. Dedico também à minha noiva Giovanna Toschi Bambicini, pelo seu amor, carinho e compreensão. 


\section{AGRADECIMENTOS}

Primeiramente agradeço ao Instituto de Pesquisas Energéticas e Nucleares (IPEN-CNEN/SP), ao Centro de Ciência e Tecnologia de Materiais (CCTM) e à Universidade de São Paulo (USP), pela oportunidade de realização deste estudo de Doutoramento.

Agradeço ao Conselho Nacional de Desenvolvimento Científico e Tecnológico (CNPq) pela concessão da bolsa durante o período de Doutorado.

À comissão de pós-graduação do IPEN-CNEN/SP, por todo o apoio oferecido durante o período de doutoramento.

À Dra. Emília Satoshi Miyamaru Seo pela orientação, apoio, dedicação, paciência, experiência e amizade, durante todos esses anos como aluno de iniciação científica, mestrado e doutorado.

Ao Marco Andreoli pela experiência, discussão e amizade durante os anos convividos com o grupo de pesquisas.

Ao Dr. Rubens Chiba pelo apoio, discussão, colaboração e amizade.

Ao Dr. Antonio Carlos da Silva e ao Dr. Luiz Fernando Grespan Setz por todo apoio, incentivo e amizade.

À Dra. Sonia R. H. M. Castanho, Dra Dolores R. R. Lazar e Dr. Valter Ussui, pelas colaborações na infraestrutura dos laboratórios.

Ao Dr. Walter Kenji Yoshito e a Dra. Chieko Yamagata pelas discussões, incentivo e amizade.

Ao Dr. Marcelo Linardi pelo apoio e colaboração ao grupo de Células a Combustível de Óxido Sólido do CCTM. 
Ao Dr. Fabio Coral Fonseca, Dra. Eliana Arico, além das colegas Shayenne, Natália e do colega Franscisco, pelas colaborações nas medidas de caracterizações térmicas e elétricas.

Ao Dr. Thomaz Augusto Guisard Restivo pelo entendimento teórico, colaboração na realização das análises de expansão térmica e amizade.

Ao Dr. Jose Roberto Martinelli pelo entendimento teórico e realização das análises de distribuição granulométrica.

Ao M.Sc. Edson Pereira Soares colaboração, prontidão nos momentos de auxílio e amizade.

À M.Sc. Liz Zanchetta D'Agostino pela realização das análises microestruturais e toda discussão para sua compreensão.

Aos funcionários da biblioteca Terezine Arantes Ferraz localizada no IPEN-CNEN/SP e da biblioteca da Poli-USP, pela total atenção e eficiência.

A todos os doutores, funcionários e alunos do IPEN-CNEN/SP, da Escola Politécnica (Poli-USP), do Instituto de Química (IQ-USP); entre outros, que direta ou indiretamente cooperaram de alguma forma para este trabalho. 
"Além da mente humana e como um impulso livre, cria-se a Ciência. Esta se renova, assim como as gerações, frente a uma atividade que constitui o melhor jogo do homo ludens: a ciência é no mais estrito e melhor dos sentidos, uma gloriosa diversão" (Jacques Barzun). 


\title{
SÍNTESE, PROCESSAMENTO E CARACTERIZAÇÃO DE CÁTODO \\ PARA APLICAÇÃO EM CÉLULAS A COMBUSTÍVEL DE ÓXIDO SÓLIDO DE TEMPERATURA INTERMEDIÁRIA
}

\author{
REINALDO AZEVEDO VARGAS
}

\section{RESUMO}

Os filmes micrométricos contendo óxido misto de lantânio, estrôncio, cobalto e ferro $\left(\mathrm{La}_{0,60} \mathrm{Sr}_{0,40}\right)\left(\mathrm{Co}_{0,20} \mathrm{Fe}_{0,80}\right) \mathrm{O}_{3-\delta}$ - LSCF, misturado com $\left(\mathrm{Ce}_{0,90} \mathrm{Gd}_{0,10}\right) \mathrm{O}_{1,95}$ - $\mathrm{CGO}$, são relevantes para a utilização como camada funcional para o cátodo da Célula a Combustível de Óxido Sólido de Temperaturas Intermediárias. Estes filmes foram depositados no um substrato cerâmico e denso de CGO ou CGO sobre $\left(\mathrm{ZrO}_{2}\right)_{0.92}\left(\mathrm{Y}_{2} \mathrm{O}_{3}\right)_{0.08}$ - YSZ. O estudo deste cátodo é fundamental, pois é nele que ocorre a reação de redução do gás oxigênio, e o seu desempenho eletroquímico depende da interface destes dois materiais. Neste sentido, o presente trabalho contribui para a síntese dos particulados de LSCF para o processamento de filmes, utilizando a técnica de deposição com uso de aerógrafo e para sua conformação em camadas contendo porosidade com espessuras entre 30 e $50 \mu \mathrm{m}$. Inicialmente, os particulados de LSCF foram sintetizados pela técnica do citratos e de LSCFCGO obtidos por mistura mecânica, sendo caracterizados por DRX para a confirmação da formação da estrutura cristalina ortorrômbica para o LSCF e cúbica para CGO. Em seguida, foram preparadas suspensões orgânicas de LSCF, LSCFCGO e CGO que foram alimentadas por gravidade em um aerógrafo manual para deposição sobre substrato do eletrólito. Para a conformação dos substratos de CGO ou YSZ, utilizou-se prensa uniaxial e isostática, sinterização e retificação. Verificaram-se, pelas micrografias, que os substratos CGO e YSZ apresentaram densidades (> 92\%) suficientes para serem utilizados como eletrólitos. Os filmes de LSCF e LSCFCGO apresentaram-se com porosidades adequadas (> 30\%) e espessura total de aproximadamente $40 \mu \mathrm{m}$, com boa aderência ao eletrólito. A presença do cátodo compósito contendo eletrólito de CGO sobre YSZ possibilitou aumento de $25 \%$ no desempenho eletroquímico $\left(2,50 \Omega . \mathrm{cm}^{2}\right.$ para $\left.650^{\circ} \mathrm{C}\right)$ em decorrência da melhora na reação de redução do oxigênio na interface cátodo/eletrólito. 


\title{
SYNTHESIS, PROCESSING AND CHARACTERIZATION OF CATHODE FOR APPLICATION IN INTERMEDIATE TEMPERATURE SOLID OXIDE FUEL CELLS
}

\author{
REINALDO AZEVEDO VARGAS
}

\begin{abstract}
The study of micrometrics films of $\left(\mathrm{La}_{0.60} \mathrm{Sr}_{0.40}\right)\left(\mathrm{Co}_{0.20} \mathrm{Fe}_{0.80}\right) \mathrm{O}_{3-\delta}-\mathrm{LSCF}$ mixture with $\left(\mathrm{Ce}_{0.90} \mathrm{Gd}_{0.10}\right) \mathrm{O}_{1.95}$ - $\mathrm{CGO}$ is relevant for use as functional cathode of Intermediate Temperature Solid Oxide Fuel Cells (ITSOFC). These films were deposited on the CGO or CGO and YSZ dense ceramic substrate, used as electrolyte, structural component of the module. The study of this cathode is fundamental, because is there that occurs oxygen reduction reaction, and the electrochemical performance depends on the interface of these two materials. In this sense, this work contributes for the synthesis of LSCF particulates, for processing films using the wet powder spraying technique, adopted for the conformation of the ceramic films for allowing the attainment porous layers with thicknesses between 30 and $50 \mu \mathrm{m}$. Initially, the LSCF particulates were synthesized by the citrate technique and the LSCFCGO produced by solid mixture were characterized by XRD to confirm the formation of LSCF orthorhombic structure and CGO cubic structure. In the stage of formation were prepared organic suspensions of LSCF, LSCFCGO and CGO fed by gravity in a manual airbrush for electrolyte substrate deposition, sintering and grinding for thickness reduction. The micrographs showed that the CGO and YSZ substrates were dense (> 92\%) enough to be used as solid electrolyte. The LSCF and LSCFCGO films presented with adequate porosity (> 30\%) and total thickness of approximately 40 $\mu \mathrm{m}$, with good adhesion to electrolyte. The presence of the composite cathode containing CGO or YSZ electrolyte allowed the increase of $25 \%$ in the electrochemical performance $\left(2.50 \Omega . \mathrm{cm}^{2}\right.$ to $\left.650^{\circ} \mathrm{C}\right)$ due to improvement in the oxygen reduction reaction at the interface cathode/electrolyte.
\end{abstract}




\section{SUMÁRIO}

LISTA DE TABELAS

LISTA DE ILUSTRAÇÕES ..................................................................................

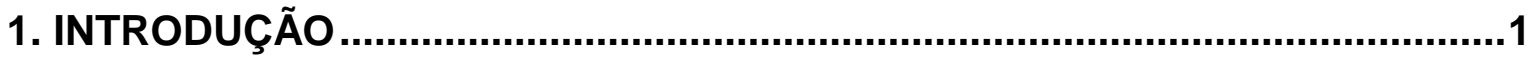

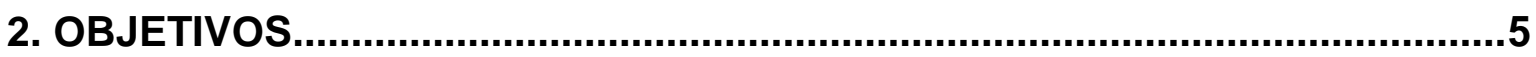

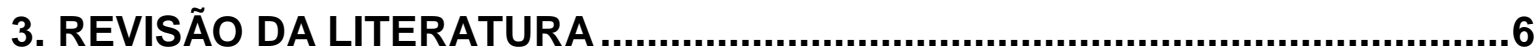

3.1. Panorama geral sobre as Células a Combustível......................................6

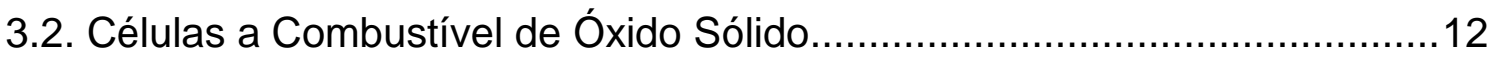

3.3. Vantagens e desvantagens da ITSOFC ………................................... 18

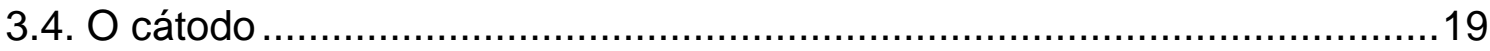

3.5. Meia-células de óxido sólido: cátodo/compósito/eletrólito .........................21

3.6. Síntese do cátodo e obtenção do cátodo compósito ....................................26

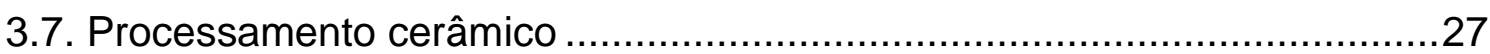

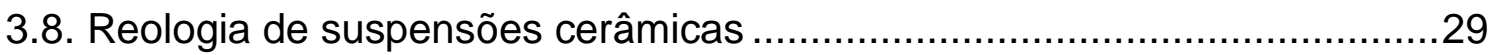

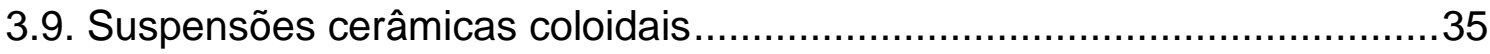

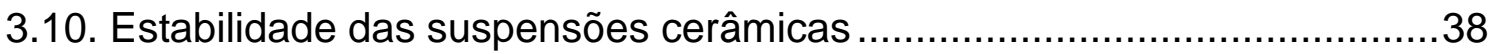

3.11. Conformação a partir de suspensões cerâmicas......................................39

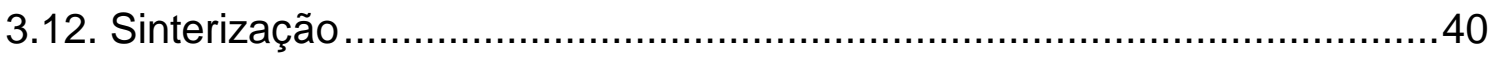

3.13. Técnicas de processamento cerâmico …................................................. 42

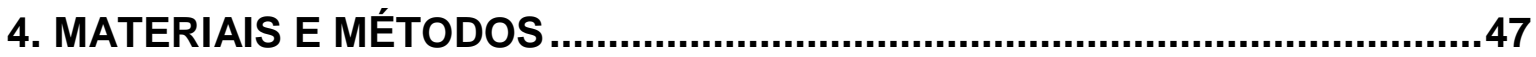

4.1. Matérias-primas e reagentes utilizados ................................................4

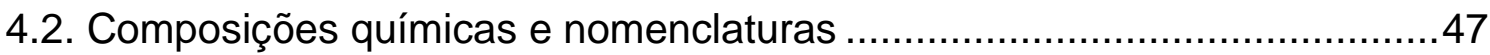

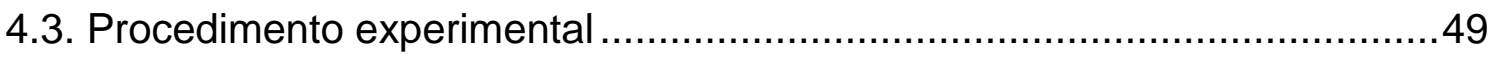

4.3.1. Preparação dos eletrólitos (substratos) de CGO ou YSZ.....................49

4.3.2. Preparação do cátodo LSCF e cátodos compósitos LSCFCGO ...........51

4.3.3. Preparação das suspensões LSCF, LSCFCGO e CGO ......................55

4.3.4. Conformação por wet powder spraying...........................................56

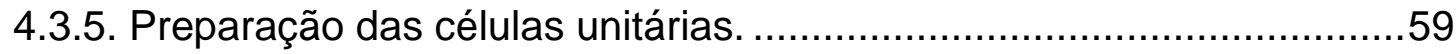

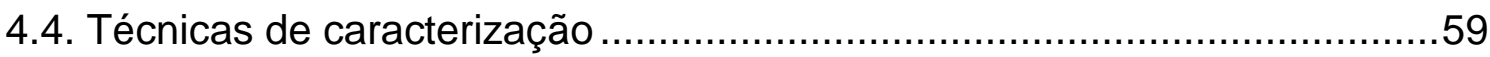




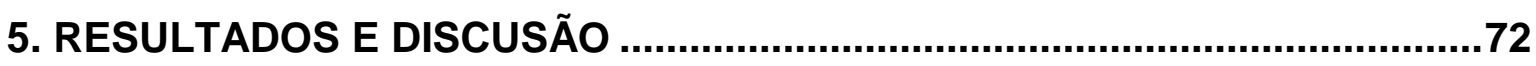

5.1. Caracterização dos materiais particulados .............................................72

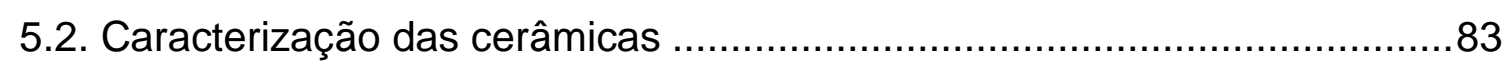

5.3. Caracterização das suspensões cerâmicas .........................................114

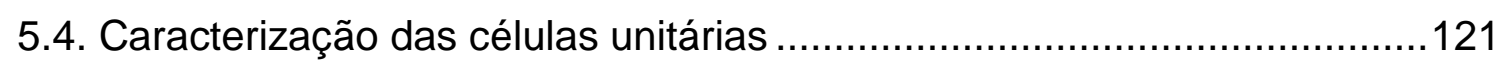

5.5. Caracterização eletroquímica das meia-células ....................................128

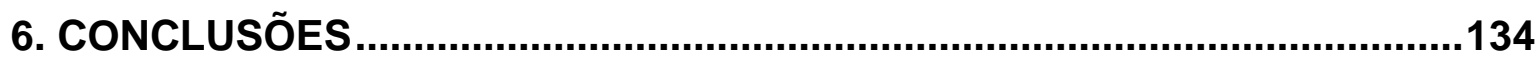

7. SUGESTÕES PARA TRABALHOS FUTUROS .........................................136

REFERÊNCIAS BIBLIOGRÁFICAS.....................................................137 


\section{LISTA DE TABELAS}

Tabela 3.1 - Principais grupos e variações de células a combustível e suas características.

Tabela 3.2 - Velocidades de cisalhamento típicas dos principais .28

Tabela 3.3 - Viscosidades de materiais empregados em diferentes setores .30

Tabela 3.4 - Modelos reológicos mais frequentes. .34

Tabela 3.5 - Parâmetros indicados para a técnica por wet poder spraying. .46

Tabela 4.1 - Composição química e nomenclatura adotadas neste trabalho. 48

Tabela 4.2 - Informações das suspensões utilizadas para as deposições. .55

Tabela 5.1 - Perda de massa durante a ATG para as amostras de LSCF. .75

Tabela 5.2 - Composições químicas das amostras sintetizadas. .79

Tabela 5.3- Caracterização física dos materiais particulados. .80

Tabela 5.4 - Carbono residual presente nos compostos LSCF. .81

Tabela 5.5- Valores das densidades geométricas a "verde" e teórica. .85

Tabela 5.6- Valores das densidades geométricas $\left(\mathrm{g} / \mathrm{cm}^{3}\right)$ dos sinterizados. .86

Tabela 5.7- Valores das densidades aparentes $\left(\mathrm{g} / \mathrm{cm}^{3}\right)$ dos sinterizados .87

Tabela 5.8 - Porosidades (\%) das cerâmicas sinterizadas. .87

Tabela 5.9 - Variações de composição, médias e desvios padrões das amostras de LSCF sinterizadas a $1100,1200,1300$ e $1400^{\circ} \mathrm{C}$ por 1 hora. 


\section{LISTA DE ILUSTRAÇÕES}

Figura 3.1 - Eficiência da célula a combustível: comparação com..........................7

Figura 3.2- Principais grupos de células a combustível ${ }^{(35)}$................................... 10

Figura 3.3 - Representação ilustrativa da região da tripla fase reacional..............15

Figura 3.4 - Representação da operação de uma célula unitária da SOFC...........16

Figura 3.5 - TBP do LSCF (a) e do compósito LSCFCGO (b)...........................22

Figura 3.6 - Ilustração representativa da estrutura pseudo-perovskita. ................24

Figura 3.7 - Representação da estrutura tipo fluorita para o eletrólito YSZ. ….....24

Figura 3.8 - Ilustração das reações envolvidas na técnica dos citratos. ...............26

Figura 3.9 - Fluxograma do processamento de materiais cerâmicos....................27

Figura 3.10 - Gráfico representativo dos fluidos independentes do tempo. ..........32

Figura 3.11 - Gráfico representativo dos fluidos dependentes do tempo...............33

Figura 3.12 - Ilustração representativa da dupla camada elétrica.........................36

Figura 3.13 - Representação ilustrativa dos principais estágios da sinterização. . 41

Figura 3.14 - Principais configurações da célula unitária...................................42

Figura 3.15 - Aerógrafo automático (a) e manual (b), para deposições. ................44

Figura 3.16 - llustração dos aerógrafos de ação simples (A) e dupla ação (B).....46

Figura 4.1 - Superfícies sinterizadas a $1500^{\circ} \mathrm{C}$ por $1 \mathrm{~h}$ antes e após lixamento. ...50

Figura 4.2 - Sequência ilustrativa da síntese de LSCF pela técnica dos citratos. . 51

Figura 4.3 - Sequência ilustrativa para a formação dos particulados do LSCF.....52

Figura 4.4 - Particulados do LSCFCGO11 (a), LSCF (b) e CGO (c)...................52

Figura 4.5 - Fluxograma da síntese de LSCF pela técnica dos citratos. ................53

Figura 4.6 - Fluxograma da fabricação de LSCFCGO por mistura de sólidos. .....54

Figura 4.7 - Ilustração do aerógrafo e diagrama da seção transversal. .................57

Figura 4.8 - Ilustração da distância entre o bocal e o substrato com ......................57

Figura 4.9 - Etapas envolvidas no processamento cerâmico................................58

Figura 4.10 - Célula unitária no lado do cátodo sobre eletrólito de CGO (a) e YSZ

(b) e ânodo (platina) sobre eletrólito de CGO (c) e YSZ (d)................................59

Figura 4.11 - Ilustração de um circuito elétrico com diagrama de Nyquist. ............70

Figura 4.12 - Esquema de caracterização eletroquímica das células unitárias.....71 
Figura 5.1 - Análise termogravimétrica da resina preliminar constituída de LSCF.

Figura 5.2 - Análise termogravimétrica das resinas variando o teor de cobalto.....74 Figura 5.3 - Difratogramas de raios X do LSCF (A) e LSCF10 ou LSCF20 (B). ....75 Figura 5.4 - Refinamento pelo método de Rietveld para o LSCF..............................76 Figura 5.5 - Difratogramas de raios $X$ dos particulados de LSCFCGO. ……….........77 Figura 5.6- Difratogramas de raios $X$ dos particulados de CGO e YSZ. ..................78

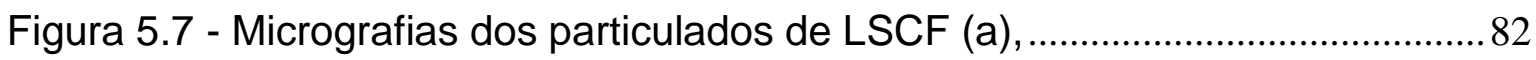
Figura 5.8 - Micrografias dos particulados de CGO (a) e YSZ (b) comerciais. .......83 Figura 5.9 - Retração linear das cerâmicas de LSCF e CGO. ...................................... 84

Figura 5.10 - Taxa de retração linear das cerâmicas de LSCF e CGO. …………..... 85

Figura 5.11 - DRX das amostras sinterizadas de LSCF........................................... 88

Figura 5.12 - DRX do LSCFCGO31(a), LSCFCGO11(b) e LSCFCGO13(c)...........89

Figura 5.13 - DRX das amostras sinterizadas de CGO............................................90

Figura 5.14 - Micrografia da cerâmica de LSCF11 com identificação quantitativa dos elementos químicos e composições atômicas por EDS.

Figura 5.15 - Micrografia da cerâmica de LSCF12 com identificação quantitativa dos elementos químicos e composições atômicas por EDS.

Figura 5.16 - Micrografia da cerâmica de LSCF13 com identificação quantitativa dos elementos químicos e composições atômicas por EDS. 93

Figura 5.17 - Micrografia da cerâmica de LSCF14 com identificação quantitativa dos elementos químicos e composições atômicas por EDS.

Figura 5.18 - Micrografia da cerâmica de LSCFCGO3111 com identificação quantitativa dos elementos químicos e composições atômicas por EDS.

Figura 5.19- Micrografia da cerâmica de LSCFCGO3112 com identificação quantitativa dos elementos químicos e composições atômicas por EDS. .98

Figura 5.20 - Micrografia da cerâmica de LSCFCGO1111 com identificação quantitativa dos elementos químicos e composições atômicas por EDS.

Figura 5.21 - Micrografia da cerâmica de LSCFCGO1112 com identificação quantitativa dos elementos químicos e composições atômicas por EDS.

Figura 5.22 - Micrografia da cerâmica de LSCFCGO1311 com identificação quantitativa dos elementos químicos e composições atômicas por EDS. 101

Figura 5.23 - Micrografia da cerâmica de LSCFCGO1312 com identificação quantitativa dos elementos químicos e composições atômicas por EDS. 
Figura 5.24 - Micrografia de CGO13 com identificação por EDS. 103

Figura 5.25 - Micrografia de CGO14 com identificação por EDS. 104

Figura 5.26 - Micrografia de YSZ com identificação por EDS. 105

Figura 5.27 - Micrografias das superfícies fraturadas, polidas e atacadas termicamente para as amostras de LSCF sinterizadas a $900^{\circ} \mathrm{C}$ por 1 hora $(A)$,

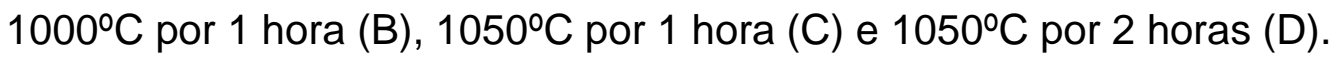
107

Figura 5.28 - Micrografias das superfícies fraturadas, polidas e atacadas termicamente para as amostras de LSCF sinterizadas a $1100^{\circ} \mathrm{C}$ por 1 hora $(\mathrm{E})$, $1200^{\circ} \mathrm{C}$ por 1 hora $(F), 1300^{\circ} \mathrm{C}$ por 1 hora $(G)$ e $1400^{\circ} \mathrm{C}$ por 1 hora $(H)$.

Figura 5.29 - Micrografias das superfícies fraturadas, polidas e atacadas termicamente para as amostras de CGO sinterizadas a $1000^{\circ} \mathrm{C}$ por 1 hora $(\mathrm{A})$, $1100^{\circ} \mathrm{C}$ por 1 hora (B), $1200^{\circ} \mathrm{C}$ por 1 hora (C) e $1250^{\circ} \mathrm{C}$ por 1 hora (D).

Figura 5.30 - Micrografias das superfícies fraturadas, polidas e atacadas termicamente para as amostras de CGO sinterizadas a $1250^{\circ} \mathrm{C}$ por 2 horas (E), $1300^{\circ} \mathrm{C}$ por 1 hora $(\mathbf{F}), 1400^{\circ} \mathrm{C}$ por 1 hora $(\mathbf{G})$ e $1500^{\circ} \mathrm{C}$ por 1 hora $(\mathbf{H})$. 110

Figura 5.31 - Micrografias das superfícies fraturadas, polidas e atacadas termicamente para as amostras de LSCFCGO31 (A e B), LSCFCGO11 (C e D) e LSCFCGO13 (E e F), sinterizadas a $1100^{\circ} \mathrm{C}$ por 1 hora (A, C e E) e a $1200^{\circ} \mathrm{C}$ por 1 hora (B, D e F). 111

Figura 5.32 - Micrografias das superfícies fraturadas, polidas e atacadas termicamente para as amostras de YSZ sinterizadas a $1200^{\circ} \mathrm{C}$ por 1 hora $(A)$, $1300^{\circ} \mathrm{C}$ por 1 hora (B), $1400^{\circ} \mathrm{C}$ por 1 hora (C e D) e $1500^{\circ} \mathrm{C}$ por 1 hora (E e F). 113 Figura 5.33 - Mobilidade eletroforética das dispersões de LSCF e CGO. .............115 Figura 5.34 - Estabilidades das suspensões de LSCF sem e ...................................116 Figura 5.35 - Estabilidades das suspensões de CGO sem (A) e com ......................117 Figura 5.36 - Micrografias dos filmes de LSCF preparados com ..............................119 Figura 5.37 - Curvas de viscosidades das suspensões de LSCF e LSCFCGO11.

Figura 5.38 - Curvas de fluxo para as suspensões de LSCF e LSCFCGO. 120

Figura 5.39- Superfícies dos filmes: LSCF (A), LSCFCGO (B), LSCF-LSCFCGO (C), substrato de CGO (D), LSCF-LSCFCGO-CGO (E), substrato de YSZ (F) e seção transversal da meia-célula LSCF-LSCFCGO-CGO-YSZ (G) . .....................122 Figura 5.40 -Micrografias dos filmes micrométricos sobre substrato de CGO. ....123 Figura 5.41 - Micrografias das seções transversais dos filmes sobre 
Figura 5.42 - Micrografia da seção transversal da meia célula 125

Figura 5.43 - Micrografia da seção transversal da meia célula 125

Figura 5.44 - Micrografia da seção transversal da meia célula 127

Figura 5.45 - Micrografia da seção transversal da meia célula constituída 127

Figura 5.46 - Circuito equivalente para a caracterização elétrica por impedância.

Figura 5.47 - Curvas de polarização do sistema $A$ 130

Figura 5.48 - Curvas de polarização do sistema B. 130

Figura 5.49 - Impedância eletroquímica do sistema A. 131

Figura 5.50 - Impedância eletroquímica do sistema B. 132 


\section{INTRODUÇÃO}

O progresso da humanidade requer cada vez mais a geração de energia elétrica de uma forma sustentável, confiável e eficiente, devido principalmente, ao crescimento da população, ao excessivo consumo e aos impactos ambientais e sociais causados pela enorme dependência de fontes não renováveis de energia, gerando, cada vez mais, altos níveis de compostos poluentes na atmosfera e em todo ecossistema ${ }^{(1,2)}$.

Para uma geração de energia elétrica sustentável e eficiente, o termo "Célula a Combustível" (do inglês Fuel Cell), também conhecido no Brasil como "Pilha a Combustível", conquista destaque, embora esta tecnologia ainda não esteja bem estabelecida comercialmente ${ }^{(2)}$.

Com a crescente preocupação em relação ao aquecimento global e em obter fontes de energias ambientalmente limpas, os biocombustíveis e o hidrogênio serão os sucessores dos combustíveis fósseis. As pesquisas sobre o hidrogênio estão sendo concentradas para a geração de energia elétrica, térmica e de água por meio das Células a Combustível. O hidrogênio é o composto mais básico e sua combustão é totalmente limpa, sendo o grande concorrente a se tornar o vetor energético do futuro e transformando a atual economia, concentrada no petróleo, em uma economia baseada no hidrogênio ${ }^{(1,3)}$.

Dentro deste contexto, o presente trabalho que faz parte das pesquisas científicas e tecnológicas do grupo de pesquisas que trabalha com a tecnologia de Células a Combustível de Óxidos Sólidos (Solid Oxide Fuel Cell - SOFC) pertencentes ao Centro de Células a Combustível e Hidrogênio $(\mathrm{CCCH})$ e ao Centro de Ciência e Tecnologia de Materiais (CCTM) do Instituto de Pesquisas Energéticas e Nucleares (IPEN-CNEN/SP), localizado dentro da Universidade de São Paulo (USP), na cidade de São Paulo, é de grande importância.

O projeto atual do grupo tem como objetivo preliminar a fabricação e caracterização de estruturas compostas de camadas de materiais cerâmicos laminadas do tipo positivo-eletrólito-negativo, conhecidas como células unitárias e constituídas de camadas conjugadas de: cátodo (positivo), eletrólito e ânodo (negativo) $^{(2,4)}$. 
As células unitárias são conectadas eletricamente em série e/ou em paralelo para gerar potência (quantidade de energia concedida por uma fonte a cada unidade de tempo) por meio de um componente conhecido como placa bipolar ${ }^{(5)}$, sendo que para a célula de óxido sólido, tais placas são conhecidas como interconectores ${ }^{(6)}$.

As camadas laminadas são fabricadas por técnicas de conformação e posterior deposição a partir de suspensões cerâmicas. Estas técnicas são muito utilizadas para a fabricação de materiais com espessuras micrométricas com boa reprodutibilidade e custos moderados ${ }^{(7,8)}$.

Os estudos realizados pelo grupo de pesquisas do IPEN-CNEN/SP visam colaborar com o desenvolvimento da tecnologia de fabricação de células unitárias cerâmicas de SOFCs, primeiramente na forma planar, obtendo estruturas adequadas para serem testadas em diversas condições de operação. Entre as barreiras tecnológicas para a produção em larga escala, estão sua reprodutibilidade da alta temperatura de operação e elevado custo de processamento dos distintos componentes, além que acarretam reações que ocorrem nas interfaces entre os componentes, durante a operação. A utilização comercial destes dispositivos tem como desafio a redução no valor do quilowatthora (kWh) gerado, que é relativamente elevado se comparado com formas tradicionais e convencionais de geração de energia elétrica ${ }^{(3,4)}$.

As Células a Combustível de Óxidos Sólidos de Temperaturas Intermediarias (Intemediate Temperature Solid Oxide Fuel Cells - ITSOFCs) operam atualmente entre 500 e $700^{\circ} \mathrm{C}{ }^{(9)}$. Este intervalo de temperatura de operação é interessante em decorrência das perdas nas propriedades químicas (reação entre os componentes), térmicas (favorecimento de tensões térmicas) e mecânicas (fadiga); resultando em perdas nas propriedades que comprometem o desempenho deste dispositivo quando operado por longos períodos de tempo em temperaturas superiores a $750^{\circ} \mathrm{C}^{(4,10)}$.

A diminuição da temperatura de operação interfere na densidade de corrente, em decorrência da redução da cinética dos processos envolvidos (condutividade elétrica dos componentes, reações nas interfaces, cinética dos eletrodos, entre outros), sendo um dos principais fatores causadores do aumento no sobrepotencial do eletrodo positivo (cátodo) ${ }^{(811)}$. 
Por estes motivos, é necessário o desenvolvimento de materiais alternativos que apresentem maior condutividade elétrica, mais atividade catalítica para reação de redução do oxigênio (RRO), alta extensão da região da tripla fase reacional (Triple Phase Boundary - TPB) e coeficiente de expansão térmica (Thermal Expansion Coefficient - TEC) compatível com o eletrólito sólido para evitar tensões nas interfaces ${ }^{(10,12)}$. Além disso, o material deve possuir baixa reatividade química com os componentes adjacentes, manter boa aderência na interface com o eletrólito e apresenta porosidade para boa difusão de fases durante a operação da célula ${ }^{(6,12)}$.

O óxido misto constituído de lantânio (La), estrôncio (Sr), cobalto (Co) e Ferro (Fe), identificado pela nomenclatura $\left(\mathrm{La}_{1-x} \mathrm{Sr}_{x}\right)\left(\mathrm{Co}_{1-y} \mathrm{Fe}_{\mathrm{y}}\right) \mathrm{O}_{3-\delta}-\mathrm{LSCF}$, é um material de estrutura cristalina do tipo pseudo-perovskita que apresenta praticamente todos estes requisitos e seu grande interesse deve-se, principalmente, à importante propriedade de condutividade mista (iônica e eletrônica) ${ }^{(13)}$. Este material é um condutor adequado para operar em temperaturas de até $750^{\circ} \mathrm{C}$, necessitando prepará-lo com uma microestrutura contendo porosidade para permeação do gás oxidante (ar ou oxigênio puro), homogênea distribuição granulométrica de suas partículas e aumentar as compatibilidades química e térmica com os componentes da ITSOFC ${ }^{(12,14)}$.

Em uma ITSOFC utiliza-se, normalmente, o $\left(\mathrm{Ce}_{0,90} \mathrm{Gd}_{0,10}\right) \mathrm{O}_{1,95}$ - CGO ou $\left(\mathrm{Ce}_{0,85} \mathrm{Sm}_{0,15}\right) \mathrm{O}_{1,925}$ - CSO como eletrólito. A substituição parcial do cério (Ce) por gadolínio (Gd) ou samário ( $\mathrm{Sm}$ ), de valência inferior, produz vacâncias de íons oxigênio $\left(\mathrm{O}^{2-}\right)$ ao redor do cério substituído que, ao ser ocupado pelo $\mathrm{O}^{2-}$ adjacente, adquire a propriedade de condução iônica ${ }^{(15,16)}$.

O grande desafio para melhorar o desenvolvimento das SOFCs é diminuir as resistências de polarização ôhmica e de concentração, sobretudo no cátodo. Uma alternativa efetiva é a introdução de uma camada intermediária composta por um material compósito, constituído normalmente pelos materiais do eletrólito e do cátodo que no caso de uma ITSOFC são CGO e LSCF, respectivamente. Esta camada melhora o contato entre o cátodo e o eletrólito, diminuindo a resistência ôhmica devido ao aumento na extensão da região da TPB, onde ocorre a RRO, além de melhorar também a aderência com o LSCF. Este material compósito é conhecido atualmente como cátodo compósito, cátodo funcional ou camada funcional ${ }^{(17,18,19)}$. 
Dentre as diferentes rotas de síntese encontradas na literatura para a fabricação do LSCF, destaca-se a técnica dos citratos, derivada do método PECHINI ${ }^{(20)}$, que é adotada na obtenção de precursores poliméricos para obtenção de materiais particulados com características adequadas para preparação de suspensões aquosas ou orgânicas, com condições boas para as etapas de processamento e conformação cerâmica ${ }^{(13,21)}$.

O cátodo compósito é preparado por meio de uma mistura mecânica de óxidos, também conhecida como mistura de sólidos, utilizando geralmente um moinho para conseguir misturas homogêneas ${ }^{(8 ; 22)}$.

Dentro deste propósito, e da necessidade de se estudar melhor a ciência dos materiais destes dispositivos, este trabalho de doutorado compreende: a síntese ou obtenção de LSCF com composição nominal $\left(\mathrm{La}_{0,60} \mathrm{Sr}_{0,40}\right)\left(\mathrm{Co}_{0,20} \mathrm{Fe}_{0,80}\right) \mathrm{O}_{3-\delta}$ pela técnica dos citratos, preparação de cátodos compósitos constituídos de LSCF e CGO (LSCFCGO) por mistura de óxidos (mistura de sólidos); a caracterização física, química e microestrutural dos materiais particulados, com a finalidade de preparar suspensões cerâmicas estáveis e deposição por wet powder spraying primeiramente no substrato de eletrólito constituído de CGO; além da caracterização destes materiais, a montagem como cátodo, contribui para a confecção de uma célula unitária da ITSOFC. A composição nominal foi definida de acordo com resultados de trabalhos anteriores do grupo e da literatura técnica ${ }^{(23,24,25)}$.

Para a obtenção de uma TPB maior e distribuída homogeneamente, a técnica de conformação por aerografia foi adotada neste trabalho. Cabe salientar que são poucos os trabalhos relativos ao estudo de conformação por esta técnica de suspensões de LSCF e LSCFCGO, propósito da presente Tese. Outras técnicas utilizadas para a conformação em filmes nas SOFCs são: impressão sobre tela, deposição eletroforética, recobrimento por rotação, recobrimento por imersão, colagem de fita, spray pirólise, entre outros ${ }^{(7,8)}$.

A originalidade deste trabalho está na: preparação de suspensões cerâmicas de LSCF e LSCFCGO e a utilização da técnica de conformação por aerografia (wet powder spraying) para a formação das camadas micrométricas de LSCF; preparação de compósitos LSCF/CGO sobre o substrato de CGO e obtenção das células unitárias de óxidos sólidos cátodo/compósito/eletrólito com características adequadas para aplicação em ITSOFCs. 


\section{OBJETIVOS}

Considerando a importância das células a combustível, principalmente das células constituídas de óxidos sólidos (SOFCs), e visando uma contribuição à inovação tecnológica, o presente trabalho de doutoramento tem como objetivo geral a obtenção de células de óxidos sólidos com características adequadas para a utilização em ITSOFCs. Neste contexto, inserem-se como objetivos específicos:

- Caracterização dos materiais particulados de $\left(\mathrm{Ce}_{0,90} \mathrm{Gd}_{0,10}\right) \mathrm{O}_{1,95}$ - $\mathrm{CGO}$ e $\left(\mathrm{ZrO}_{2}\right)_{0.92}\left(\mathrm{Y}_{2} \mathrm{O}_{3}\right)_{0.08}$ - YSZ comerciais, processamento por prensagem uniaxial e isostática e caracterização das cerâmicas sinterizadas;

- Síntese e caracterização dos materiais particulados de óxido misto constituído de lantânio, estrôncio, cobalto e ferro $\left(\mathrm{La}_{0,60} \mathrm{Sr}_{0,40}\right)\left(\mathrm{Co}_{0,20} \mathrm{Fe}_{0,80}\right) \mathrm{O}_{3-\delta}$ - LSCF e de três diferentes compósitos de LSCF com CGO (LSCFCGO) formando um gradiente funcional;

- Processamento cerâmico via wet powder spraying (aerografia) das suspensões cerâmicas de LSCF, LSCFCGO e CGO;

- Caracterização eletroquímica das células unitárias cátodo/compósito/eletrólito/ânodo visando o desempenho eletródico dos filmes micrométricos de LSCF e LSCFCGO para a reação de redução do oxigênio.

Algumas considerações importantes para o ineditismo da presente Tese são descritos a seguir. $O$ efeito da adição de nitrato de cobalto, como elemento dopante, é um objetivo complementar deste trabalho, pois o estudo foi definido com 0 trabalho em andamento. $O$ objetivo relevante para o propósito deste trabalho é o de caracterizar, eletroquimicamente, eletrodos de $\left(\mathrm{La}_{0,60} \mathrm{Sr}_{0,40}\right)\left(\mathrm{Co}_{0,20} \mathrm{Fe}_{0,80}\right) \mathrm{O}_{3-\delta}$ depositados sobre eletrólitos (substratos densos) de CGO ou YSZ. Essa caracterização visa contribuir para o entendimento das etapas limitantes nas reações envolvidas no cátodo de uma ITSOFC. 


\section{REVISÃO DA LITERATURA}

Antes de abordar os temas ligados com o propósito deste trabalho, é importante informar que o termo em inglês "Fuel Cells" possui atualmente três principais traduções dentro da língua portuguesa: "Células a Combustível", "Células de Combustível" e "Pilhas a Combustível". Entretanto, considerou-se que o termo "Células a Combustível" é o mais coerente, visto que representa a tradução mais adequada do inglês, além de possuir a correta semântica das palavras; pois são células que funcionam com a presença de um combustível.

\subsection{Panorama geral sobre as Células a Combustível}

O panorama das células a combustível é bastante difundido, devido principalmente à geração de energia de uma forma mais distribuída e a utilização do gás hidrogênio como um elemento combustível. As células e o hidrogênio estão fortemente ligados, pois além das pesquisas e desenvolvimentos das células, deve-se também um grande estudo ao vetor energético hidrogênio, que pode ser produzido a partir de recursos fósseis (carvão, petróleo e gás natural), renováveis (biomassa), da eletrólise da água utilizando energia produzida por fontes como a solar, eólica, hidráulica, entre outros ${ }^{(1-4)}$.

Por definição, as células a combustível são dispositivos eletroquímicos que convertem diretamente a energia química em energia elétrica e térmica (calor), pela combinação eletroquímica de um gás combustível com um oxidante. O princípio de operação foi demostrado por William Robert Grove em $1839{ }^{(2)}$. Em 1899, com a descoberta dos eletrólitos sólidos por Walther Nernst, surgiu a célula a combustível de óxidos sólidos (ou células a combustível cerâmicas) que operavam inicialmente em temperaturas superiores a $850^{\circ} \mathrm{C}^{(2,3)}$.

Esses dispositivos estão sendo considerados como uma opção real para a geração de energia elétrica conhecida como distributiva em diversos países, devido à sua baixa emissão de poluentes, possibilidade de construção modular, baixo nível de ruídos, produção simultânea de energia elétrica e térmica, pouca restrição quanto à localização e alta eficiência de conversão (45 a 65\%) dependendo do tipo de tecnologia empregada ${ }^{(3)}$. 
A característica mais importante de uma célula a combustível é a sua alta eficiência para a geração de energia, pois, como converte diretamente a energia química entre combustível e oxidante em energia elétrica e não necessita de nenhum processo de combustão interna, sua eficiência de conversão não está relacionada com os limites termodinâmicos do ciclo de Carnot (Figura 3.1a), possuindo uma eficiência de sistema maior que os motores a combustão atuais até a uma temperatura de operação de aproximadamente $1200^{\circ} \mathrm{C}{ }^{(3,4)}$.

As células a combustível também possuem eficiência superior aos motores elétricos movidos a álcool, gasolina ou óleo diesel, e as turbinas movidas a gás ou a vapor (Figura 3.1b). Entretanto, a eficiência eletroquímica máxima teórica das células a combustível é de aproximadamente $65 \%{ }^{(3,4)}$.

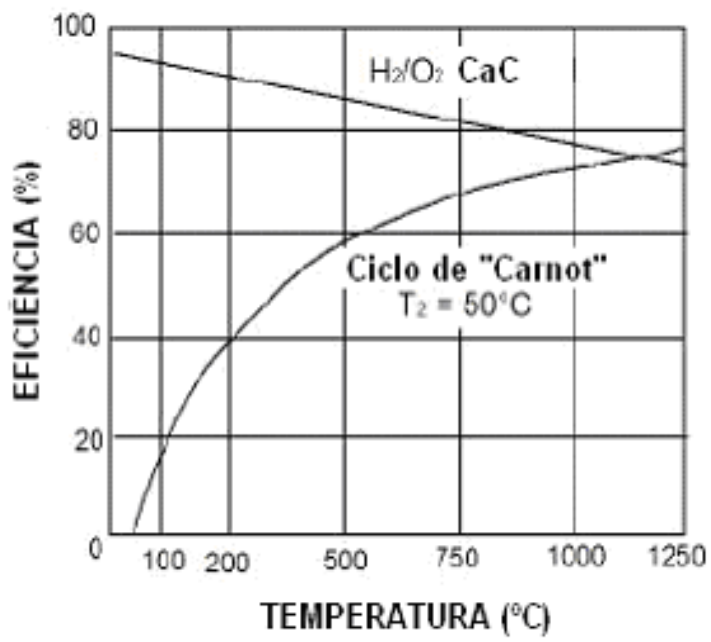

(a)

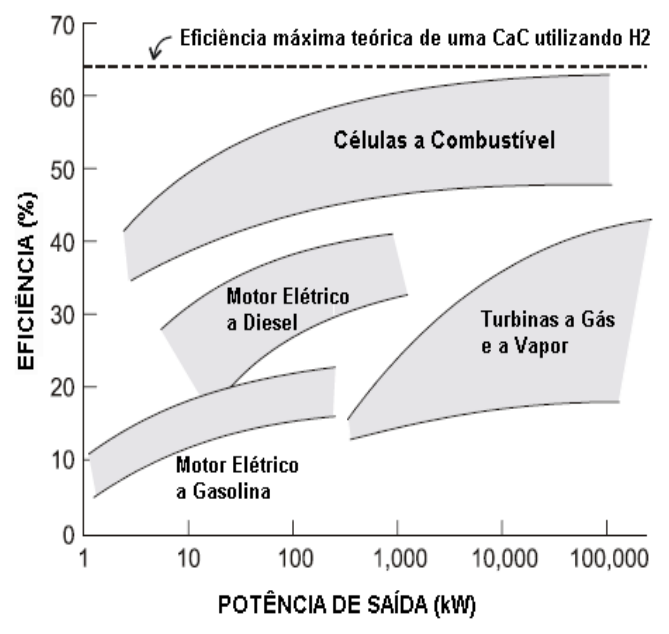

(b)

Figura 3.1 - Eficiência da célula a combustível: comparação com o ciclo de Carnot (a) e com motores elétricos e turbinas (b) ${ }^{(3,4)}$.

Para conseguir maiores eficiências, é necessário utilizar a cogeração, cuja eficiência teórica de sistema pode chegar a até $85 \%$ para algumas tecnologias de células a combustível que operam em temperaturas elevadas ${ }^{(2)}$.

Além disso, quando comparada com métodos convencionais de geração de energia elétrica, às células a combustível oferecem vantagens como: emissão reduzida de poluentes, construção modular, potencial para cogeração (geração de energia elétrica e térmica simultaneamente), ausência de componentes no estado líquido (eliminando principalmente os problemas de 
corrosão), possibilidade da reforma interna de combustíveis, pois em altas temperaturas de operação, geralmente superiores a $600^{\circ} \mathrm{C}$, podem resultar em altas cinéticas das reações químicas envolvidas ${ }^{(2-4)}$.

A tensão de operação $E$ de uma célula a combustível é sempre inferior à máxima tensão $E_{0}$ (Equação 1) que a mesma pode produzir (lei de Nernst), devido às resistências internas e perdas de corrente por polarizações ${ }^{(2 ; 4)}$.

$$
E_{0}=\frac{R T}{4 F} \int_{p O_{2}}^{p " O_{2}} d\left(\ln p O_{2}\right)=\frac{R T}{4 F} \ln \left(\frac{p^{\prime \prime} O_{2}}{p^{\prime} O_{2}}\right)
$$

onde $\mathbf{R}=8,314 \mathrm{~J}^{*} \mathrm{~mol}^{-1}{ }^{-1} \mathrm{~K}, \mathbf{T}$ é a temperatura absoluta, $\mathbf{F}=9,649^{*} 10^{4}$ $\mathrm{C}^{*} \mathrm{~mol}^{-1}$ e $\boldsymbol{p}^{\prime} \mathrm{O}_{2}$ e $\boldsymbol{p}^{\prime \prime} \mathrm{O}_{2}$ são as pressões parciais de oxigênio. Entretanto, a tensão de operação de uma célula pode ser determinada por:

$$
E=E_{0}-I R_{i}-\left(\eta_{\mathrm{a}}+\eta_{c}\right)
$$

Onde: I é a corrente elétrica que atravessa a célula, $\mathbf{R}_{\mathbf{i}}$ é a resistência interna da célula (também chamada de perda ôhmica e relacionada principalmente à resistência do próprio eletrólito) e $\eta_{\mathrm{a}}$ e $\eta_{\mathrm{c}}$ são as polarizações anódicas e catódicas, respectivamente ${ }^{(2,4)}$.

As perdas por polarizações estão associadas às reações eletroquímicas que ocorrem nas interfaces eletrodo/eletrólito (cátodo/eletrólito ou ânodo/eletrólito), fundamental no desempenho de uma célula a combustível.

Uma SOFC típica consiste de dois eletrodos porosos (ânodo e cátodo) separados por um eletrólito sólido e denso. O combustível em contato com o ânodo é oxidado, liberando elétrons através de um circuito externo. O oxidante em contato com o cátodo é reduzido, capturando elétrons. O fluxo de elétrons (do ânodo para o cátodo) pelo circuito externo é chamado de corrente elétrica (2).

Os eletrólitos mais utilizados nas ITSOFCs são cerâmicas avançadas que apresentam boa condutividade iónica (íons $\mathrm{O}^{2-}$ ) e estabilidade em atmosferas oxidantes e redutoras ${ }^{(26,27,28)}$. Os eletrodos mais utilizados são condutores mistos (iônicos e eletrônicos) que possuem estrutura cristalina similar a perovskita e que apresentam alta atividade catalítica. 
No caso do eletrodo negativo (ânodo) é comum o uso de cermets com níquel e no caso do eletrodo positivo (cátodo) os óxidos mistos baseados principalmente em lantânio e estrôncio ${ }^{(26,29,30)}$.

A estequiometria da estrutura perovskita $\left(\mathrm{ABO}_{3}\right)$ tem normalmente cátions de terras raras ocupando os sítios $A$ e cátions de metais de transição ocupando os sítios $B$. Os cátions dos sítios $A$ apresentam número de coordenação 12 com os ânions da rede e os cátions dos sítios B apresentam número de coordenação 6 com os ânions da rede, formando um octaedro ${ }^{(31)}$.

As reações catódicas ocorrem na superfície e no volume do cátodo bem como na interface cátodo/eletrólito, sendo que ocorre na região da tripla fase reacional, que é a interface entre os poros, preenchida pelo gás (ar ou oxigênio) e os materiais do eletrodo e eletrólito ${ }^{(6)}$. Estes processos normalmente são limitantes para as reações no cátodo e podem ser atribuídas à: difusão gasosa (externa ao eletrodo ou em seus poros); adsorção do oxigênio na superfície do eletrodo ou eletrólito; difusão do oxigênio adsorvido sobre o eletrodo, sobre o eletrólito até a tripla fase reacional, ou na interface eletrodo/eletrólito, além de transferência de carga através da interface eletrodo/eletrólito ${ }^{(6,32)}$.

Entretanto, para compreender conceitualmente a polarização catódica é necessária a identificação de cada um dos possíveis processos, além da determinação das etapas limitantes de cada um. Apesar de existir uma concordância a respeito das possíveis reações citadas acima, restam incertezas com relação às etapas limitantes ${ }^{(33)}$. O parâmetro utilizado na determinação desses processos limitantes é a resistência elétrica dos eletrodos como função da temperatura e/ou da pressão parcial de oxigênio ${ }^{(5,33)}$.

A maneira mais usual de se analisar o transporte de carga elétrica em uma célula a combustível ou em seus componentes é por meio de medidas de espectroscopia de impedância eletroquímica ${ }^{(33,34)}$. Essas medidas são fundamentais no estudo das SOFCs e de seus componentes, permitindo a análise tanto de mecanismos básicos, quanto a avaliação do desempenho elétrico da própria célula unitária (cátodo/eletrólito/ânodo).

As células a combustível são classificadas de acordo com o tipo de eletrólito empregado e consequentemente, com a sua temperatura de operação. A Figura $3.2^{\left({ }^{(35)}\right.}$ diferencia os cinco principais grupos de células a combustível. 


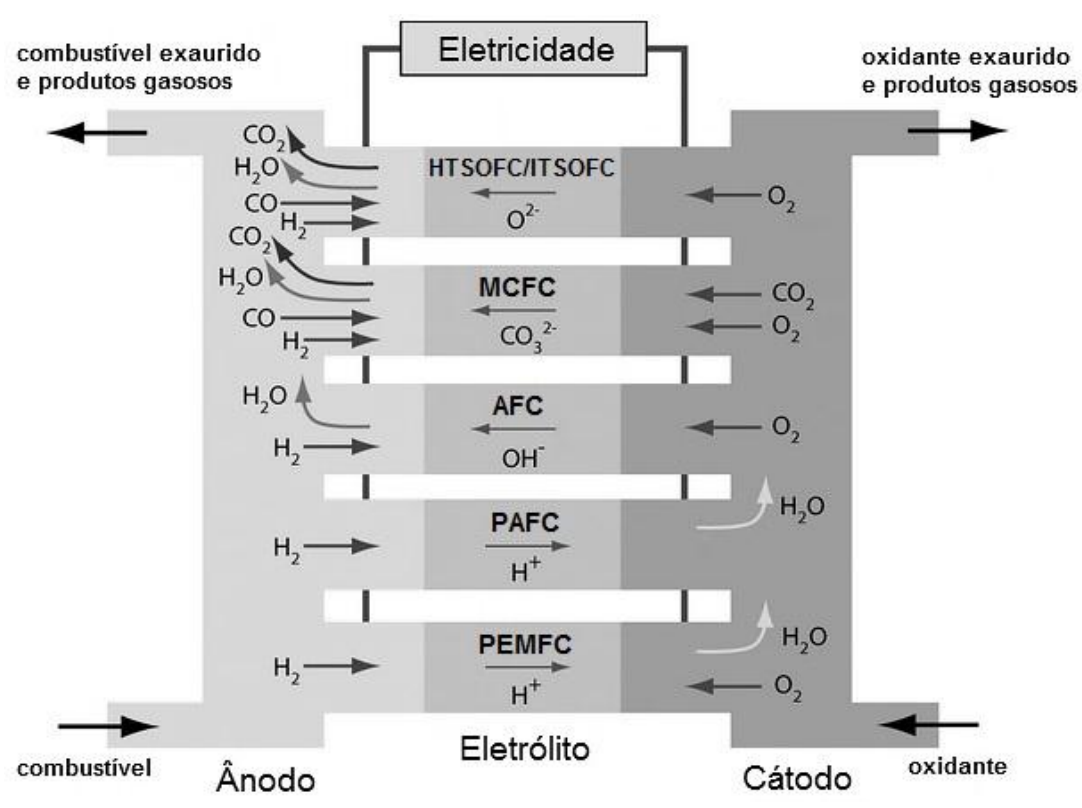

Figura 3.2- Principais grupos de células a combustível ${ }^{(35)}$.

Os principais grupos de células a combustível que operam em baixa temperatura (entre 60 e aproximadamente $250^{\circ}$ C) são: a AFC (Alkaline Fuel Cell Célula a Combustível Alcalina), PEMFC (Proton Exchange Membrane Fuel Cell Célula a Combustível de Membrana Polimérica Trocadora de Prótons) e PAFC (Phosphoric Acid Fuel Cell - Célula a Combustível de Ácido Fosfórico); e as que operam em temperaturas mais elevadas (entre 400 e $1000^{\circ} \mathrm{C}$ ) são: MCFC (Molten Carbonate Fuel Cell - Célula a Combustível de Carbonato Fundido) e SOFC (Solid Oxide Fuel Cell - Célula a Combustível de Óxidos Sólidos) ${ }^{(2,4)}$.

As células a combustível de baixa temperatura possuem um potencial de aplicação para propulsão de automóveis (tração elétrica) e podem ser utilizadas para aplicações estacionárias que demande unidades de alguns quilowatts $(\mathrm{kW})$ de energia gerada, visando residências, pequenos comércios, hospitais, escolas, entre outros. As células que operam em temperaturas mais elevadas são apropriadas para contínua produção simultânea de energia/calor, onde a temperatura da célula pode ser mantida ${ }^{(3,4)}$.

A Tabela 3.1 apresenta as características sobre esses grupos de células a combustível contendo também suas principais variações ${ }^{(5,36,37)}$. 
Tabela 3.1 - Principais grupos e variações de células a combustível e suas características.

\begin{tabular}{|c|c|c|c|c|c|c|c|}
\hline $\begin{array}{l}\text { Grupo ou } \\
\text { Variação }\end{array}$ & Eletrólito & $\begin{array}{c}\text { İon } \\
\text { Transportado }\end{array}$ & $\begin{array}{c}\text { Temperatura de } \\
\text { Operação }\left({ }^{\circ} \mathrm{C}\right)\end{array}$ & Vantagens & Desvantagens & Principais Aplicações & $\begin{array}{c}\text { Eficiência } \\
\text { Teórica (\%) }\end{array}$ \\
\hline $\begin{array}{l}\text { Membrana } \\
\text { polimérica } \\
\text { (PEMFC) }\end{array}$ & $\begin{array}{c}\text { Polímero } \\
\text { condutor de } \\
\text { prótons (nafion }{ }^{\circledR} \text { ) }\end{array}$ & $\mathrm{H}^{+}$ & $\begin{array}{c}80-120 \\
160-220\end{array}$ & $\begin{array}{l}\text { Elevada densidade de } \\
\text { potência, flexibilidade de } \\
\text { operação e mobilidade }\end{array}$ & $\begin{array}{c}\text { Custo elevado da } \\
\text { membrana e } \\
\text { contaminação do } \\
\text { catalisador pelo CO }\end{array}$ & $\begin{array}{l}\text { Veículos terrestre, } \\
\text { aéreo ou espacial e } \\
\text { unidades portáteis }\end{array}$ & $45-50$ \\
\hline $\begin{array}{l}\text { Membrana } \\
\text { polimérica } \\
\text { (DMFC) }\end{array}$ & $\begin{array}{c}\text { Polímero } \\
\text { condutor de } \\
\text { prótons (nafion }{ }^{\circledR} \text { ) }\end{array}$ & $\mathrm{H}^{+}$ & $\begin{array}{c}80-120 \\
160-220\end{array}$ & $\begin{array}{l}\text { Oxidação direta do } \\
\text { álcool (metanol) }\end{array}$ & $\begin{array}{l}\text { Permeabilidade da } \\
\text { membrana e baixos } \\
\text { valores de corrente e } \\
\text { potência }\end{array}$ & $\begin{array}{l}\text { Veículos terrestre, } \\
\text { aéreo ou espacial e } \\
\text { unidades portáteis }\end{array}$ & 40 \\
\hline $\begin{array}{l}\text { Líquido } \\
\text { iônico } \\
\text { (PAFC) }\end{array}$ & $\begin{array}{c}\text { Ácido fosfórico } \\
\text { 90-100\% } \\
\left(\mathrm{H}_{3} \mathrm{PO}_{4}\right)\end{array}$ & $\mathrm{H}_{3} \mathrm{O}^{+}$ & $160-220$ & $\begin{array}{c}\text { Maior desenvolvimento } \\
\text { tecnológico }\end{array}$ & $\begin{array}{c}\text { Vida útil limitada pela } \\
\text { corrosão, difícil controle } \\
\text { da porosidade do } \\
\text { eletrodo e sensibilidade } \\
\text { a CO }(<2 \%)\end{array}$ & $\begin{array}{l}\text { Unidades estacionária } \\
\text { (100kW a alguns MW) e } \\
\text { cogeração (energia } \\
\text { elétrica e térmica) }\end{array}$ & $40-50$ \\
\hline $\begin{array}{l}\text { Líquido } \\
\text { iônico } \\
\text { (AFC) }\end{array}$ & $\begin{array}{l}\text { Hidróxido de } \\
\text { potássio } \\
\text { concentrado } \\
(\mathrm{KOH})\end{array}$ & $\mathrm{OH}^{-}$ & $60-120$ & Alta eficiência (83\%) & $\begin{array}{c}\text { Sensível a } \mathrm{CO}_{2}, \\
\text { necessita de gases com } \\
\text { alta pureza e difícil } \\
\text { remoção de água }\end{array}$ & $\begin{array}{l}\text { Veículos espaciais e } \\
\text { aplicações militares }\end{array}$ & $>80$ \\
\hline $\begin{array}{l}\text { Carbonato } \\
\text { fundido } \\
\text { (MCFC) }\end{array}$ & $\begin{array}{l}\text { Misturas de } \\
\text { carbonatos } \\
\text { fundidos }\end{array}$ & $\mathrm{CO}_{3}{ }^{2-}$ & $600-700$ & $\begin{array}{c}\text { Tolerância a } \mathrm{CO} \text { e } \mathrm{CO}_{2} \\
\text { eletrodos a base de } \\
\text { níquel, reforma interna } \\
\text { do combustível e alta } \\
\text { eficiência teórica }\end{array}$ & $\begin{array}{l}\text { Corrosão do cátodo, } \\
\text { necessidade de } \\
\text { reciclagem de } \mathrm{CO}_{2} \text { e } \\
\text { interface de difícil } \\
\text { controle }\end{array}$ & $\begin{array}{l}\text { Unidades estacionária } \\
\text { (100kW a 1MW) e } \\
\text { cogeração (energia } \\
\text { elétrica e térmica) }\end{array}$ & $>60$ \\
\hline $\begin{array}{l}\text { Óxido } \\
\text { sólido } \\
\text { (HTSOFC) }\end{array}$ & $\begin{array}{l}\text { Óxido de zircônio } \\
\text { estabilizado com } \\
\text { óxido de ítrio } \\
\left(\mathrm{ZrO}_{2} / \mathrm{Y}_{2} \mathrm{O}_{3}\right)\end{array}$ & $\mathrm{O}^{2-}$ & $\begin{array}{c}800-1000 \\
700-900\end{array}$ & $\begin{array}{l}\text { Reforma interna do } \\
\text { combustível e alta } \\
\text { eficiência teórica }\end{array}$ & $\begin{array}{l}\text { Problemas de materiais } \\
\text { e alta expansão térmica }\end{array}$ & $\begin{array}{l}\text { Unidades estacionária } \\
\text { (10kW a 1MW) e } \\
\text { cogeração (energia } \\
\text { elétrica e térmica) }\end{array}$ & $>60$ \\
\hline $\begin{array}{l}\text { Óxido } \\
\text { sólido } \\
\text { (ITSOFC) }\end{array}$ & $\begin{array}{l}\text { Óxido de cério } \\
\text { dopado com } \\
\text { gadolínio ou } \\
\text { samário } \\
\left(\mathrm{Ce}_{1-\mathrm{x}} \mathrm{Gd}_{\mathrm{x}} \mathrm{O}_{1,95} \text { ou }\right. \\
\left.\mathrm{Ce}_{1-\mathrm{x}} \mathrm{Sm}_{\mathrm{x}} \mathrm{O}_{1,95}\right)\end{array}$ & $\mathrm{O}^{2-}$ & $\begin{array}{l}600-800 \\
500-700\end{array}$ & Alta eficiência teórica & $\begin{array}{l}\text { Problemas de materiais, } \\
\text { expansão térmica e } \\
\text { necessidade de pré- } \\
\text { reforma do combustível }\end{array}$ & $\begin{array}{l}\text { Unidades estacionária } \\
\text { (10kW a 1MW) e } \\
\text { cogeração (energia } \\
\text { elétrica e térmica) }\end{array}$ & $>60$ \\
\hline
\end{tabular}




\subsection{Células a Combustível de Óxido Sólido}

As SOFCs vieram 60 anos depois dos princípios reportados por William Robert Grove e se iniciaram com a descoberta do eletrólito de óxido sólido por Walther Hermann Nerst, em $1899^{(5)}$. A primeira suposta SOFC operando a, aproximadamente, $1000^{\circ} \mathrm{C}$ foi construída por Baur e Preis em $1937^{(4,38)}$.

Este tipo de célula somente começou a despertar interesse como fonte na produção de energia elétrica após a crise energética da década de 1970. Porém, com a atual preocupação ambiental e a busca por fontes alternativas de geração de energia, as SOFCs despontam como candidatas promissoras, por possibilitarem a geração de energia elétrica de alta potência de uma maneira eficiente, econômica, segura, silenciosa e ecologicamente limpa ${ }^{(38)}$.

Em particular, as SOFCs possuem como vantagens a alta eficiência e a possibilidade de reforma interna do combustível (para obtenção de gás hidrogênio) dentro da própria célula; sendo assim, de grande aplicação para unidades estacionárias e em cogeração envolvendo eletricidade e calor ${ }^{(11,38)}$.

As aplicações das SOFCs estão sendo direcionadas para unidades estacionárias na faixa de dezenas de kW a alguns megawatts (MW) de potência elétrica, principalmente para hospitais, condomínios residenciais, construções comerciais, entre outros ${ }^{(2,4)}$. Devido a sua temperatura de operação, o processo gera energia térmica e vapor d'água condensado. $O$ calor liberado com o vapor pode ser reaproveitado no processo de geração de energia em turbina a gás (cogeração), aumentando o rendimento acima de $80 \%{ }^{(4,38)}$.

Atualmente, o grupo das SOFCs possui duas principais variações, de acordo com sua temperatura de operação. A primeira classe é conhecida como Célula a Combustível de Óxido Sólido de Temperatura Alta (High Temperature Solid Oxide Fuel Cell - HTSOFC), que opera entre 700 e $900^{\circ} \mathrm{C}{ }^{(9,38)}$. Entretanto, não tendo sido superados todos os problemas que ocorrem em seus componentes, devido à alta temperatura de operação, diversos estudos em busca de novos materiais que sejam compatíveis para operacionalizar estes dispositivos em temperaturas inferiores a $700^{\circ} \mathrm{C}$ continuam ${ }^{(9 ; 27)}$.

Em virtude dos motivos discutidos, a atenção está direcionada para a seleção e obtenção de materiais cerâmicos que possam ser utilizados como componentes na Célula a Combustível de Óxido Sólido de Temperatura 
Intermediária (Intermediate Temperature Solid Oxide Fuel Cell - ITSOFC), que opera atualmente entre 500 e $700^{\circ} \mathrm{C}^{(27,39)}$.

As SOFCs, assim como os demais tipos de células a combustível, possuem componentes extremamente importantes para 0 seu correto funcionamento e para o seu desempenho durante o período de operação ${ }^{(38)}$. As ITSOFCs, por operarem atualmente em uma faixa de temperaturas inferiores a $800^{\circ} \mathrm{C}$ requerem materiais particulares para todos os seus componentes e possuem vantagens e desvantagens quando comparadas às HTSOFCs ${ }^{(38,40)}$.

Os principais componentes de uma ITSOFC são: eletrólito, cátodo, ânodo e interconector. Todos devem atender a requisitos para utilização nos stacks (empilhamento de células unitárias), como possuir propriedades químicas, morfológicas e dimensionais bem estabilizadas em ambientes redutores e oxidantes, adequada compatibilidade química entre os seus componentes e necessidade de propriedade condutora envolvendo íons e elétrons ${ }^{(38)}$.

Os componentes dessas células devem possuir coeficientes de expansão térmica próximos para evitar a ocorrência de trincas e separação durante a fabricação e período de operação. O eletrólito e o interconector devem ser densos prevenindo a mistura de gases, enquanto o ânodo e o cátodo, além da condução mista, devem apresentar uma porosidade adequada (entre 30 e 40\%) para permitir a passagem dos gases até as regiões de reação ${ }^{(40-41)}$.

Para a ITSOFC, ainda existe uma grande quantidade de componentes que estão sendo pesquisados. Dentre estes componentes, temos principalmente o óxido misto a base de cério (Ce) com gadolínio $(\mathrm{Gd})$ ou samário $(\mathrm{Sm})$ como eletrólito; óxidos mistos baseados em lantânio e estrôncio (Sr) como cátodo; os cermets de óxido de cério com níquel (Ni) ou Ferro (Fe) como ânodo; alguns compósitos ou ligas metálicas de ferro com cromo (Cr) como interconector e materiais vitrocerâmicos como selante ${ }^{(28,32,40,42,43,)}$.

Todos estes componentes apresentam funções diferentes, apresentando para cada qual, propriedades particulares e específicas, sendo importante estudá-las individualmente, principalmente na região das interfaces entre os componentes, influenciadas pelo tipo de técnicas de processamento. Além disso, existem desafios quanto à compatibilidade de materiais e estabilidade química entre os componentes que constituem a célula unitária ${ }^{(11 ; 32 ; 44)}$. 
Descrevendo mais especificamente sobre a família dos manganitos como cátodos das $\mathrm{HTSOFCs}$, a dopagem do $\mathrm{LnMnO}_{3}(\mathrm{Ln}=\mathrm{La}, \mathrm{Nd}$, $\mathrm{Pr}, \mathrm{Ce}, \mathrm{Sm}$ e Gd) com Sr, aumenta a condutividade elétrica do material, pois ocorre o aumento de cátions $\mathrm{Mn}^{4+}$, através da substituição de cátions $\mathrm{Ln}^{3+}$ por cátions $\mathrm{Sr}^{2+}$. Isso torna esse material um dos preferencialmente utilizados como cátodo ${ }^{(6,37)}$.

Tradicionalmente, o material $\left(\mathrm{La}_{1-x} \mathrm{Sr}_{\mathrm{x}}\right) \mathrm{MnO}_{3-\delta}$ - $\mathrm{LSM}$, é o mais estudado para utilização em HTSOFCs e também o mais consolidado, devido a sua propriedade de condução mista e desempenho eletroquímico, estabilidades química e térmica e compatibilidades química e mecânica com o eletrólito sólido de $\left(\mathrm{ZrO}_{2}\right)_{0,92}\left(\mathrm{Y}_{2} \mathrm{O}_{3}\right)_{0,08}$ - YSZ ${ }^{(37)}$. Entretanto, o material catódico tradicional, LSM, apresenta alta resistência de condução iônica em temperaturas inferiores a $750^{\circ} \mathrm{C}$, devido à sua pobre condução dos íons oxigênio e o desempenho como eletrodo das células é melhorado se existirem duas fases no cátodo; uma formada pela interface do compósito LSM/YSZ e a outra, de LSM ${ }^{(37,45)}$.

Em virtude, principalmente, destes problemas existentes, e aos relacionados diretamente com o custo de manufatura, da escolha limitada de materiais e da degradação dos componentes que operam em altas temperaturas, vários esforços estão concentrados na utilização de materiais para aplicação em temperaturas intermediárias, tais como sistemas que contém lantânio (La), neodímio $(\mathrm{Nd})$, praseodímio $(\mathrm{Pr})$, cério $(\mathrm{Ce})$, gadolínio $(\mathrm{Gd})$, samário $(\mathrm{Sm})$, entre outros, estudados e pesquisados como cátodos para as ITSOFC ${ }^{(23 ; 46)}$.

A aplicação em temperaturas intermediárias (atualmente entre $500 \mathrm{e}$ $800^{\circ} \mathrm{C}$ ) reduziria extremamente os problemas associados com a fabricação e com os materiais envolvidos, melhorando a confiabilidade da própria célula durante operações em períodos mais prolongados ${ }^{(47 ; 48)}$.

Com base nestas considerações, o IPEN-CNEN/SP desenvolve processos de síntese, processamento e técnicas de caracterização desses componentes (eletrodos, eletrólitos, interconectores e selantes) visando o domínio desses materiais e processos, para que contribua na implantação de unidades geradoras de energia do tipo SOFC no Brasil. Neste sentido, o grupo técnico envolvido tem conquistado inúmeros avanços no que tange a síntese e a caracterização dos particulados cerâmicos com propriedades adequadas para a fabricação de componentes para HTOFCs e ITSOFCs ${ }^{(23,49)}$. 
Os desafios atuais estão concentrados no desenvolvimento e seleção de processos de conformação de suspensões cerâmicas economicamente viáveis para a confecção de laminados para aplicação em HTSOFC de configuração planar. Neste contexto, pretende-se também agregar os conhecimentos voltados aos processos de conformação de suspensões cerâmicas para confecção de células unitárias para aplicação em ITSOFC.

Com relação ao grande interesse pela estrutura pseudo-perovskita do material $\left(\mathrm{La}_{1-\mathrm{x}} \mathrm{Sr}_{\mathrm{x}}\right)\left(\mathrm{Co}_{1-\mathrm{y}} \mathrm{Fe}_{\mathrm{y}}\right) \mathrm{O}_{3-\delta}$, deve-se, principalmente, à sua propriedade mista de condutividade, iônica e eletrônica. Dentre as aplicações, destaca-se como: material catódico das ITSOFCs, membrana de separação de moléculas de oxigênio ${ }^{(50 ; 51)}$, como catalisador para reações de combustão de hidrocarbonetos e de redução de peróxido de hidrogênio em soluções alcalinas ${ }^{(52,53)}$.

Para um bom funcionamento da célula a combustível é importante avaliar a compatibilidade química, estabilidade térmica e porosidade entre 0 cátodo e o eletrólito. É ideal que nenhum produto da reação se forme na interface cátodo/eletrólito, pois prejudicaria o seu desempenho ${ }^{(6 ; 17)}$.

Dentre as propriedades do material do cátodo, a porosidade, o coeficiente de expansão térmica e a composição são parâmetros mais relevantes na região da tripla fase reacional (Triple Phase Boundary - TPB) estabelecida entre os gases reagentes e os materiais do eletrólito e do cátodo (Figura 3.3).

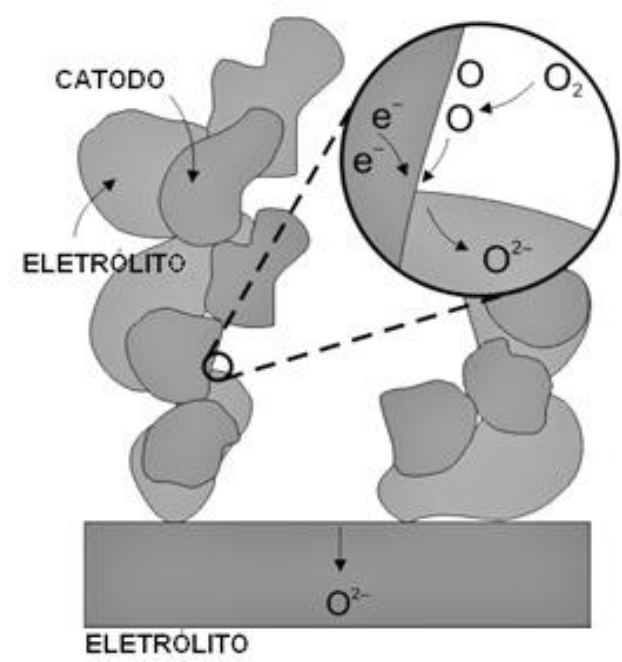

Figura 3.3 - Representação ilustrativa da região da tripla fase reacional ${ }^{(17)}$. 
Esta interface tem uma função crítica para um bom desempenho das SOFCs, pois, através das porosidades faz-se a alimentação do gás oxigênio para a região da $T P B$, sendo que quanto maior o contato entre os grãos na superfície do cátodo e do eletrólito, ou seja, maior TPB, maior será o favorecimento da reação de redução do oxigênio (RRO) ${ }^{(6 ; 38)}$.

Nos estudos realizados por Qiu et. al. ${ }^{(14)}$ verifica-se que na interface cátodo/eletrólito, o LSCF, com valores baixos de concentrações do dopante estrôncio $(x \leq 0,3)$ reage com $Y S Z$, formando zirconatos de lantânio $\left(\operatorname{La}_{2} \mathrm{Zr}_{2} \mathrm{O}_{7}=\right.$ LZO) e estrôncio $\left(\mathrm{Sr}_{2} \mathrm{Zr}_{2} \mathrm{O}_{7}=\mathrm{SZO}\right)$, que são compostos resistivos, na faixa de temperatura de sinterização até $1000^{\circ} \mathrm{C}$, que são compostos altamente resistivos.

Segundo Gupta et. al. ${ }^{(54)}$, o LSCF, com concentrações relevantes de $\mathrm{Sr}$ e Co, é excelente candidato para permeabilidade do oxigênio no cátodo devido à presença do $\mathrm{Sr}$ em sua estrutura como receptor, permitindo a formação de vacâncias de oxigênio. A presença de íons do cobalto acarreta em uma formação de energia de ligação mais baixa do que os íons do ferro. Com isso, a dopagem com ferro nos sítios do cobalto diminui o coeficiente de expansão térmica e aumenta a estabilidade termodinâmica deste material, que possui condutividade eletrônica e iônica ${ }^{(32)}$. Conforme Qiu et. al. ${ }^{(14)}$, a condutividade iônica aumenta com teores elevados de estrôncio e diminuiu com a presença do ferro.

A Figura 3.4 ilustra o funcionamento de uma SOFC, onde no eletrodo positivo (cátodo) ocorre a redução do oxigênio $\left(\mathrm{O}_{2}\right)$ para íons $\mathrm{O}^{2-}$, os quais, através do eletrólito, são conduzidos ao eletrodo negativo (ânodo).

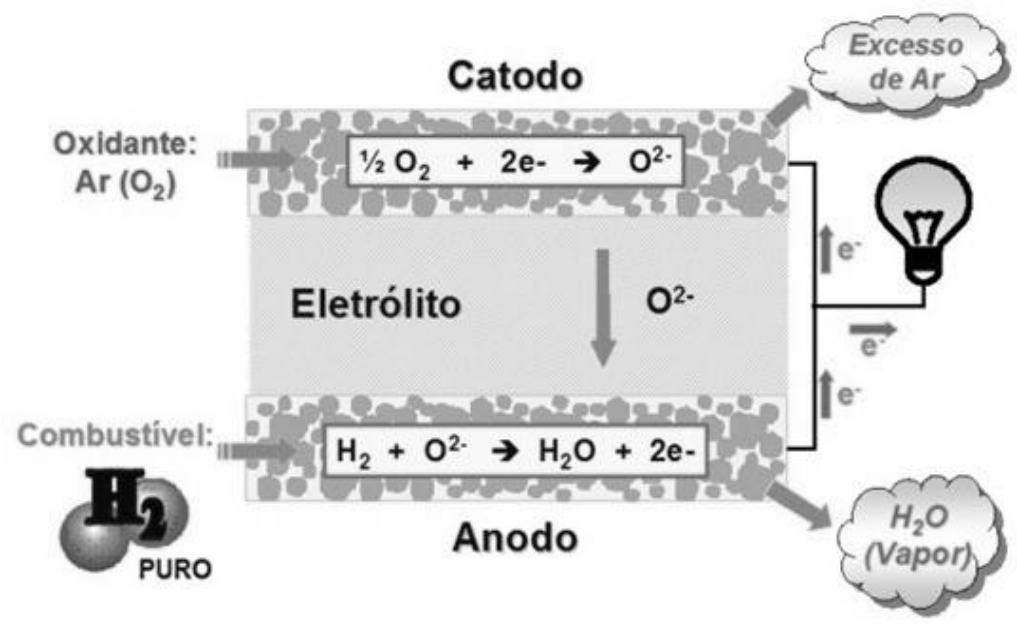

Figura 3.4 - Representação da operação de uma célula unitária da SOFC ${ }^{(23)}$. 
No ânodo ocorre a reação destes íons com o gás hidrogênio para produzir água, liberando elétrons para um circuito externo. O fluxo de elétrons do ânodo para o cátodo é responsável pela produção de eletricidade na forma de corrente elétrica contínua ${ }^{(2,4)}$.

As reações químicas envolvidas são:

$$
\begin{gathered}
\text { Cátodo: } \frac{1}{2} \mathrm{O}_{2(\mathrm{~g})}+2 \mathrm{e}^{-} \Rightarrow \mathrm{O}^{2-} \\
\text { Ânodo: } \mathrm{H}_{2(\mathrm{~g})}+\mathrm{O}^{2-} \Rightarrow \mathrm{H}_{2} \mathrm{O}_{(\mathrm{g})}+2 \mathrm{e}^{-} \\
\text {Reação global: } \frac{1}{2} \mathrm{O}_{2(\mathrm{~g})}+\mathrm{H}_{2(\mathrm{~g})} \Rightarrow \mathrm{H}_{2} \mathrm{O}_{(\mathrm{g})}
\end{gathered}
$$

A voltagem desenvolvida entre os dois eletrodos é estabelecida pela termodinâmica das reações envolvidas atingindo um valor de 1,08 volt (V) a $1000^{\circ} \mathrm{C}$ quando o combustível utilizado é o gás hidrogênio umidificado ${ }^{(4)}$.

Nas ITSOFCs existem resistências internas, que são classificadas em três tipos e denominadas de polarizações por ativação, queda ôhmica e concentração. A eficiência prática em que considera estas resistências internas é de $60 \%$. A magnitude destas resistências depende da densidade de corrente ${ }^{(4,5)}$.

A polarização por ativação se deve a velocidade finita das reações eletroquímicas envolvidas e é minimizada incorporando um eletrocatalisador à estrutura do eletrodo, de modo a aumentar a velocidade das reações. As perdas por esta polarização predominam em baixas densidades de corrente ${ }^{(5,33)}$.

A polarização por queda ôhmica é reduzida quando componentes resistivos internos seriais, como dos eletrodos, eletrólito, interfaces e contatos elétricos, são minimizados. Os eletrodos devem apresentar condutividade eletrônica e iônica adequadas e o eletrólito deve apresentar condutividade iônica alta, e possuir espessura micrométrica. Esta polarização normalmente ocorre em toda faixa de corrente elétrica ${ }^{(2 ; 33)}$.

A polarização por concentração ocorre na interface eletrodo/eletrólito, de modo que ocorra difusão lenta da fase gasosa nos poros e esgotamento das espécies reativas na TPB, a qual é reduzida, aumentando a área interfacial e porosidade dos eletrodos. Esta polarização ocorre mais significativamente em altas densidades de corrente ${ }^{(2 ; 38)}$. O desempenho de uma célula a combustível depende da minimização das polarizações citadas. 


\subsection{Vantagens e desvantagens da ITSOFC}

A ITSOFC combina as vantagens da tecnologia desenvolvida com a HTSOFC para a operação em temperaturas consideradas intermediárias (atualmente entre 500 e $700^{\circ} \mathrm{C}$ ). Atualmente, muitos componentes cerâmicos são utilizados como eletrodo (cátodo e ânodo) e eletrólito, sendo vantajoso, pois o combustível da célula pode conter hidrocarbonetos, além de $\mathrm{CO}{ }^{(55,56)}$.

O uso de um eletrólito cerâmico também evita problemas de corrosão inerente ao eletrólito líquido. Entretanto, o processo interno de reforma do combustível é prático em temperaturas superiores a $650^{\circ} \mathrm{C}$, sendo que, para a ITSOFC, será necessária uma etapa adicional de pré-reforma externa. As principais vantagens na utilização de temperaturas intermediárias são ${ }^{(2,9,27)}$ :

- menor degradação de materiais no interior da célula: auxilia a manter a área de superfície da reação;

- menor tensão térmica: a temperatura de operação mais baixa permite a utilização de menos material, facilitando a selagem da estrutura;

- maior flexibilidade de materiais: a disponibilidade de diferentes tipos de materiais que podem ser usados em temperaturas intermediárias;

- menor tempo para atingir a temperatura de operação.

A temperatura de operação mais baixa permite a construção dos componentes estruturais da ITSOFC em aço inoxidável, o que representa menor custo de fabricação em relação aos metais de custos mais elevados ${ }^{(2,4 ; 27)}$.

As desvantagens estão na condutividade do eletrólito (encontrar materiais condutores iônicos adequados para temperaturas inferiores a $750^{\circ} \mathrm{C}$ ) e na dinâmica dos eletrodos (possuir regiões de TBP suficientes para ocorrerem reações químicas no ânodo e no cátodo), que diminuem significativamente em temperaturas inferiores a aproximadamente $700^{\circ} \mathrm{C}^{(6,27)}$.

Para tentar superar esses problemas, alguns materiais alternativos estão sendo pesquisados e testados, dentre eles o LSCF e o CGO ${ }^{(32 ; 57,58,)}$. 


\section{4. $O$ cátodo}

O cátodo opera em meio oxidante, geralmente ar ou oxigênio puro em temperaturas entre 550 e $750^{\circ} \mathrm{C}$, mais efetivamente em torno de $650^{\circ} \mathrm{C}$ e participando diretamente na reação de redução do $\mathrm{O}_{2}{ }^{(4)}$ :

$$
\frac{1}{2} \mathrm{O}_{2(\mathrm{~g})}+2 \mathrm{e}^{-} \Rightarrow \mathrm{O}^{2-}
$$

Nesta situação, $0 \mathrm{O}_{2}$ gasoso é reduzido para íons oxigênio $\left(\mathrm{O}^{2-}\right)$, consumindo 2 moles de elétrons ( $\left.\mathrm{e}^{-}\right)$durante o processo. $\mathrm{O}$ cátodo presente nas ITSOFCs necessita possuir os seguintes requisitos $(27 ; 38 ; 59)$ :

- alta condutividade eletrônica;

- estabilidade dimensional e química durante a operação da célula;

- expansão térmica próxima dos outros componentes da célula;

- compatibilidade térmica e reatividade química adequadas com o eletrólito e interconector em que o cátodo está em contato;

- porosidade suficiente para facilitar o transporte do $\mathrm{O}_{2}$ para a interface cátodo/eletrólito.

Para satisfazer estes requisitos, o material deve ser convenientemente dopado com elementos alcalinos. O cátodo pode ter excesso ou deficiência de íons $\mathrm{O}_{2}$ dependendo da sua pressão parcial de $\mathrm{O}_{2}$ e da temperatura de operação em que a célula a combustível será solicitada ${ }^{(38)}$.

Várias pesquisas têm sido conduzidas para se verificar qual o melhor método de obtenção do material catódico das ITSOFCs, sendo que o mais importante é conseguir controlar de forma efetiva as seguintes variáveis, que influenciam o processo de fabricação ${ }^{(7,8)}$ :

- composição química;

- preparação e obtenção dos precursores;

- temperaturas de calcinação e sinterização;

- processos de conformação. 
O controle das variáveis acima tem como objetivo a obtenção de uma microestrutura controlada com tamanho médio de partículas homogêneas, aumentando, consequentemente, a região da $T P B^{(8,38)}$.

A literatura técnica referente aos materiais pesquisados como cátodo em ITSOFCs é formada por trabalhos realizados envolvendo a síntese de óxidos mistos baseados em neodímio ou praseodímio dopados com estrôncio ${ }^{(60,61)}$.

Segundo Zawadzki et al. ${ }^{(62)}$, o LSCF apresenta excelentes propriedades de condutividades eletrônica e iônica, assim mais adequado para ser utilizado como cátodo em ITSOFCs.

Entretanto, este material apresenta o coeficiente de expansão térmica elevado e reage com o eletrólito de YSZ. Neste sentido, a dopagem com $\mathrm{Fe}^{3+}$, $\mathrm{Ni}^{2+}$ ou $\mathrm{Mn}^{3+}$, nos sítios do cobalto, reduz significativamente o coeficiente termodinâmico deste condutor misto.

Conforme Liu et al. ${ }^{(63)}$, para a preparação dos particulados de LSCF, tem-se preferencialmente utilizado três métodos de síntese, tais como coprecipitação, mistura de sólidos e técnica dos citratos.

Para Dutta et al. ${ }^{(64)}$ é possível a obtenção de particulados do cátodo LSCF e também de eletrólitos CGO ou CSO com partículas da ordem de nanômetros pela técnica de combustão.

Conforme Wang et al. ${ }^{(48)}$, o LSCF obtido pela técnica de coprecipitação apresenta oxigênio não estequiométrico em sua composição para pressão de $\mathrm{O}_{2}$ da ordem de 1 a $10^{5} \mathrm{~Pa}$ devido a redução dos íons do cobalto e causando, consequentemente, um decréscimo da condutividade elétrica.

Pela técnica dos citratos, Lee et al. (18) sintetizaram o compósito LSCF/CGO e obtiveram após conformação cerâmica, densidade de corrente de 0,265 W. $\mathrm{cm}^{-2}$ em aproximadamente $650^{\circ} \mathrm{C}$.

Embora tenham sido realizados vários estudos sobre os eletrodos positivos, diversas pesquisas continuam evoluindo para compreender o entendimento do mecanismo de reação, bastante complexo devido à composição, microestrutura, morfologia e formação de vacâncias de íon $\mathrm{O}_{2}^{-}$no cátodo.

Além disso, o cátodo deve ser estável em atmosfera oxidante, ter condutividade eletrônica de pelo menos $50 \Omega^{-1} \mathrm{~cm}^{-1}$, porosidade entre 30 e $40 \%$ e exibir boa atividade para a RRO em condições normais de operação ${ }^{(37)}$. 
Pelo controle cuidadoso da estequiometria e das características do material particulado, outras propriedades, tais como o perfil de redução no aquecimento, o coeficiente de expansão térmica e a porosidade, podem ser adaptadas para se conseguir uma adequada compatibilidade com os outros componentes da célula unitária ${ }^{(8 ; 49,65)}$.

\subsection{Meia-células de óxido sólido: cátodo/compósito/eletrólito}

Os eletrodos e o eletrólito devem possuir características específicas a fim de obter excelência no seu desempenho e eficiência de conversão. Em uma ITSOFC, o cátodo deve apresentar as seguintes características ${ }^{(40,66)}$ :

- condutividade mista (eletrônica e iônica);

- estabilidade dimensional e química durante a operação da célula;

- expansão térmica próxima dos outros componentes da célula;

- compatibilidade térmica máxima e reatividade química mínima com o eletrólito e o interconector;

- porosidade suficiente para facilitar o transporte do oxigênio molecular da fase gasosa para a interface cátodo/eletrólito;

- $\quad$ alta atividade do eletrodo para a reação de redução do oxigênio.

Com relação ao eletrólito, são importantes as características ${ }^{(40,66)}$ :

- condutividade iônica;

- estabilidade em atmosferas oxidantes e redutoras;

- expansão térmica próxima dos outros componentes da célula;

- compatibilidade térmica e reatividade química mínima com os eletrodos;

- denso suficiente para facilitar o transporte dos íons do oxigênio;

- resistência mecânica adequada.

O LSCF satisfaz os requisitos para material catódico e é usado na forma porosa para facilitar a difusão do gás oxigênio; tem boa estabilidade 
química na TPB e também possui boa condutividade eletrônica para a condução dos elétrons que vêm do circuito externo até a região do sítio ativo ${ }^{(54)}$.

Além disso, este material deve ser estável em atmosfera oxidante, apresentar condutividade eletrônica de pelo menos de $50 \Omega^{-1 *} \mathrm{~cm}^{-1}$, condutividade elétrica de $80 \Omega^{-1 *} \mathrm{~cm}^{-1}$ a $650^{\circ} \mathrm{C}$, porosidade em torno de $35 \%$ e exibir uma boa atividade para a redução do oxigênio em condições normais de operação ${ }^{(37,54)}$.

Os óxidos de CGO e de YSZ satisfazem os requisitos para material eletrólito, sendo o YSZ utilizado na fase cúbica, com 8 a 9\% em mol de ítria. A espessura do eletrólito deve ser a mais fina possível, para reduzir a polarização por queda ôhmica e consequentemente aumentar a condutividade iônica ${ }^{(37,65)}$. A YSZ entre 8 a 8,5\% em mol de ítria apresenta um valor máximo de condutividade iônica de $0,18 \mathrm{~S}^{*} \mathrm{~cm}^{-1}$ a $1000^{\circ} \mathrm{C}$ e $0,052 \mathrm{~S}^{*} \mathrm{~cm}^{-1}$ a $800^{\circ} \mathrm{C}(3937)$.

Vários estudos têm demonstrado que para aumentar as condutividades eletrônica e iônica, principalmente a condutividade iônica, bem como elevar a atividade catalítica da reação de redução do $\mathrm{O}_{2}$, é adequado melhorar 0 desempenho das SOFCs utilizando como camada intermediária ou principal, um cátodo compósito de LSCF misturado com CGO (no caso de uma ITSOFC), para possibilitar o aumento da $T P B^{(67,68)}$. Para uma melhor compreensão dessa região ativa eletroquimicamente e conhecida como TPB, a Figura $3.5^{(37)}$ ilustra 0 mecanismo envolvido, no cátodo LSCF (a) e no cátodo compósito LSCFCGO (b).

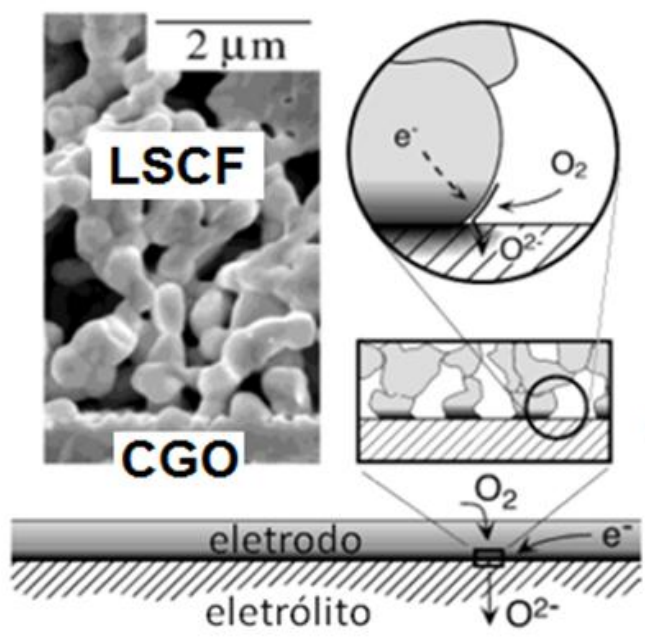

(a)

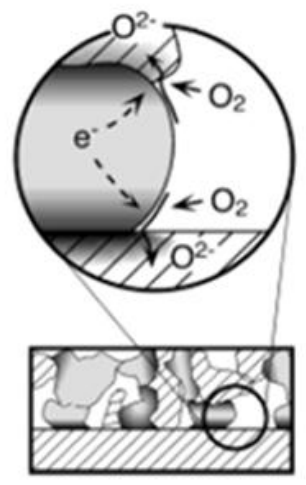

(b)

Figura 3.5 - TBP do LSCF (a) e do compósito LSCFCGO (b) ${ }^{(37)}$. 
Na TPB, a reação de troca do oxigênio entre o eletrodo e o eletrólito é composta de uma série de etapas com reações paralelas e consecutivas, aos quais incluem a adsorção do oxigênio sobre a superfície, dissociação, difusão na superfície, transferência de carga do elétron, incorporação do oxigênio para dentro do eletrólito e expulsão de vacâncias ${ }^{(4,38)}$.

De acordo com Lu et al. ${ }^{(25)}$ o desempenho eletroquímico é esperado nas camadas de eletrodos com maior TPB, mantendo-se homogênea a porosidade. O desempenho do cátodo depende da microestrutura de sua TBP, que está relacionada com as características dos particulados, como o tamanho e forma das partículas. Para um melhor desempenho, a adição de CGO, para aumentar a extensão da região ao longo do cátodo, tem sido proposta ${ }^{(67,69,70)}$.

Segundo o trabalho de Simrick et al. ${ }^{(71)}$, para maximizar o número de sítios da TPB, é preciso que o tamanho médio de grão e o tamanho dos poros estejam em uma faixa de 1 a $2 \mu \mathrm{m}$, além de possuir porosidade adequada. $\mathrm{Na}$ prática, existe dificuldade para controlar o crescimento de grão e a difusão do gás por meio dos poros, e mantidos inalterados durante a operação da célula.

Os materiais utilizados como cátodos em SOFCs são baseados na estrutura perovskita, que se apresenta em muitos compostos ternários de fórmula $\mathrm{ABO}_{3}$. Esta estrutura é derivada da cúbica de face centrada (CFC), onde os cátions $A$, juntamente com o oxigênio, formam um reticulado CFC e o cátion $B$ se encontra em posição octaédrica com átomos de oxigênio como vizinhos ${ }^{(31,72)}$.

As estruturas perovskitas podem ser dopadas, em ambos os sítios $\mathrm{A} e$ $\mathrm{B}$, com outros cátions. Os cátions com grande raio iônico ( $\mathrm{Sr}$ ou $\mathrm{Ca}$ ) substituem preferencialmente os sítios $\mathrm{A}$ e cátions com pequeno raio iônico ( $\mathrm{Co}, \mathrm{Fe}, \mathrm{Ni}, \mathrm{Mn}$ ou Cr) ocupam os sítios B dentro da estrutura ${ }^{(8 ; 31,72)}$. O LSCF possui estrutura pseudo-perovskita (Figura 3.6) ou perovskita distorcida, pois ocorre uma transição da cúbica para romboédrica, devido à influência de temperatura e dopantes ${ }^{(29,62)}$.

As alterações na estrutura poderão ser tanto substitucional, quanto intersticial, causando modificações na transformação de fase, condutividade elétrica, estequiometria do oxigênio, expansão térmica, resistência mecânica e influenciando no processo de sinterização ${ }^{(31)}$. 


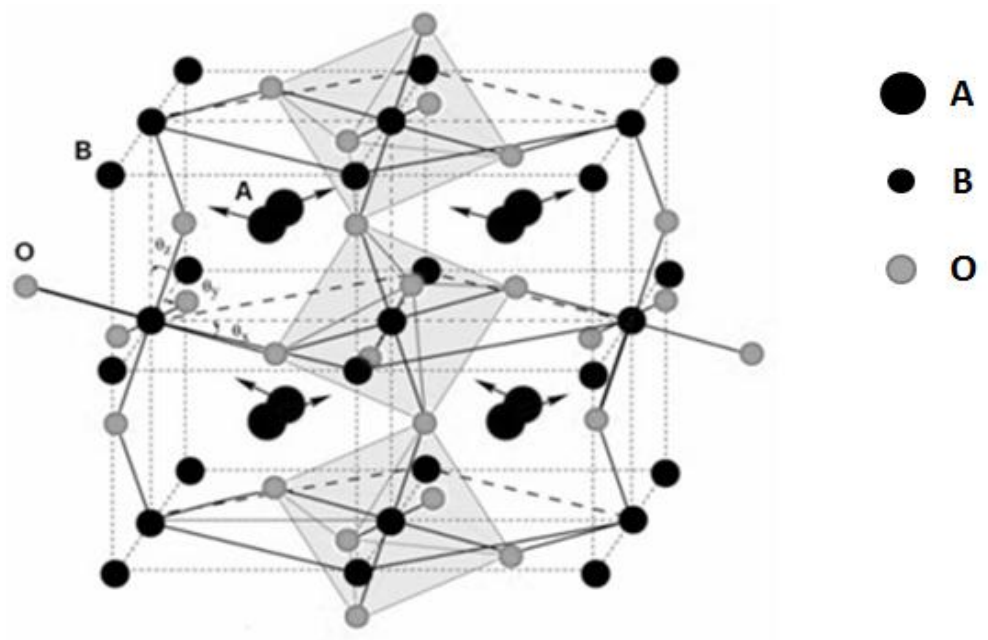

Figura 3.6 - Ilustração representativa da estrutura pseudo-perovskita ${ }^{(31,37)}$.

As alterações na estrutura poderão ser tanto substitucional, quanto intersticial, causando modificações na transformação de fase, condutividade elétrica, estequiometria do oxigênio, expansão térmica, resistência mecânica e influenciando no processo de sinterização ${ }^{(31)}$.

Os materiais usados como eletrólitos, CGO e YSZ, apresentam uma estrutura cristalina do tipo fluorita (Figura 3.7), com fórmula padrão $A B_{2}$. Nesta estrutura, os cátions formam um retículo cristalino cúbico de face centrada (CFC) e os ânions oxigênio, um retículo cristalino cúbico em posição tetraédrica ${ }^{(65,73)}$.
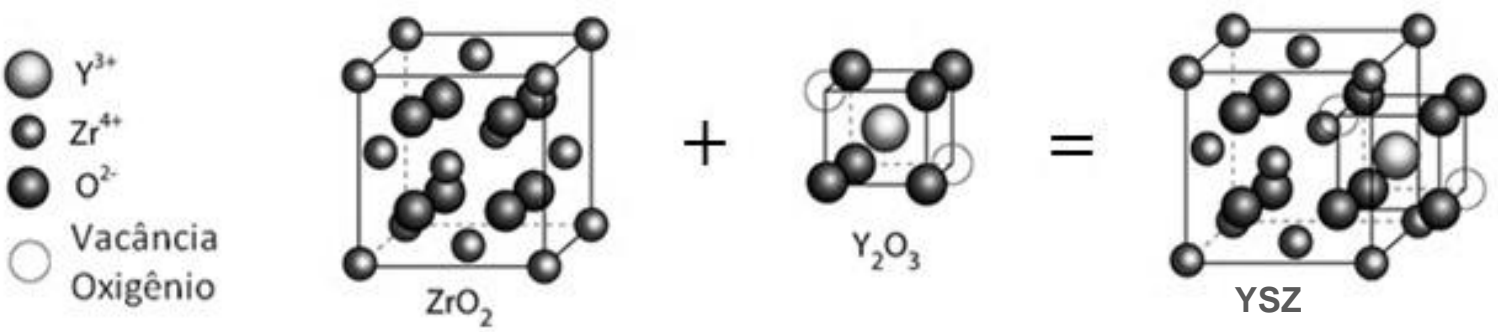

Figura 3.7 - Representação da estrutura tipo fluorita para o eletrólito YSZ ${ }^{(37)}$.

O óxido de ítrio $\left(\mathrm{Y}_{2} \mathrm{O}_{3}\right)$ é o dopante mais comum usado para estabilizar a fase cúbica do óxido de zircônio $\left(\mathrm{ZrO}_{2}\right)$ à temperatura ambiente. $\mathrm{O} \quad \mathrm{Y}_{2} \mathrm{O}_{3}$ apresenta estrutura cristalina cúbica, onde o cátion ítrio está localizado no meio desta estrutura cúbica, com seis vértices ocupados por ânions oxigênio e dois vértices não ocupados ${ }^{(37,65,74)}$. 
Para a formação da estrutura cristalina da YSZ, os cátions de zircônio são substituídos parcialmente pelos cátions de ítrio, formando uma solução sólida substitucional. Esta estabilização é acompanhada pela formação de vacâncias, responsáveis pela mobilidade dos íons oxigênio, aumentando assim a propriedade de condutividade iônica da zircônia ${ }^{(75,76)}$.

A compatibilidade química entre LSCF e CGO é descrita no trabalho de Nesaraj et al. ${ }^{(77)}$ e de Leng et al. ${ }^{(78)}$. Os particulados do cátodo compósito de LSCF/CGO foram preparados realizando uma mistura entre LSCF e CGO com razão mássica de 1:1 (um para um), em moinho do tipo atritor e posteriormente conformado em pastilhas cilíndricas com prensagem uniaxial.

No trabalho de Leng et al. ${ }^{(78)}$, os compósitos foram sinterizados a uma faixa de temperatura de 1000 a $1400^{\circ} \mathrm{C}$ e tempo de 3 a 24 horas, apresentando estrutura cristalina romboédrica para a fase LSCF e cúbica para CGO, não apresentando a formação de fases secundárias e confirmando boa compatibilidade química entre os dois materiais.

Em outro trabalho, Nielsen et al. (69) utilizaram a análise por espectroscopia de impedância eletroquímica para investigar a cinética da reação e analisaram a microestrutura para um melhor entendimento da influência da composição sobre o desempenho eletroquímico e durabilidade dos cátodos compósitos. Os cátodos estudados são constituídos de nanopartículas de LSCF e também de CGO. Os resultados indicam uma variação da quantidade de nanopartículas de CGO influenciando a microestrutura em termos de formação de TPB, com durabilidade térmica e porosidade de aproximadamente $35 \%$.

Segundo Singh et al. ${ }^{(27)}$ e Gil et al. ${ }^{(60)}$ pelo controle cuidadoso da estequiometria e características dos materiais particulados, outras propriedades como temperatura de sinterização, coeficiente de expansão térmica e porosidade, podem ser otimizadas para aumentar a compatibilidade entre os componentes.

Diversas pesquisas continuam para um melhor entendimento dos cátodos e eletrólitos relacionados ao mecanismo de reação do oxigênio e a estabilidade física, química e microestrutural na interface cátodo/eletrólito das meia-células de uma HTSOFC ou ITSOFC ${ }^{(25,79,80)}$. 


\subsection{Síntese do cátodo e obtenção do cátodo compósito}

Diferentes técnicas de síntese são encontradas na literatura, como a mistura de sólidos (ou mistura de óxidos), combustão, sol-gel, colagem por gel, coprecipitação, citratos (precursores poliméricos), entre outras ${ }^{(8 ; 27 ; 37 ; 59,49 ; 65)}$.

A técnica dos citratos foi adotada para a síntese do LSCF, devido à homogeneidade química e boa distribuição granulométrica entre as partículas. Esta técnica consiste em preparar complexos entre íons metálicos, com ácido orgânico polifuncional com no mínimo uma função hidroxila e uma carboxila, em um meio de poliálcool, seguida de polimerização, eliminação da água e da parte orgânica por aquecimento e formação dos óxidos por meio de calcinação ${ }^{(37,56)}$.

A Figura $3.8^{(37,81)}$ ilustra a representação das reações químicas envolvidas na técnica dos citratos modificada, desenvolvida originalmente por Pechini em $1967^{(20)}$.

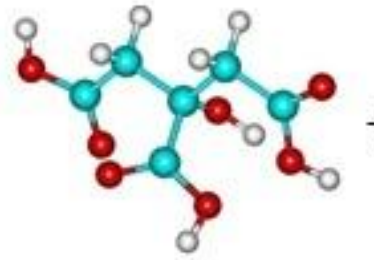

Ácido Cítrico

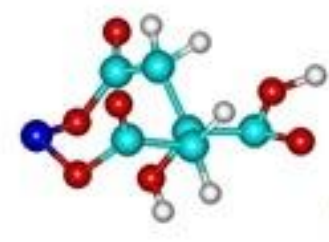

(l)

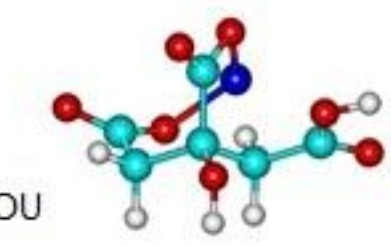

(II)

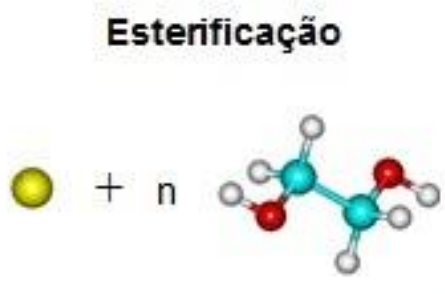

Etileno Glicol

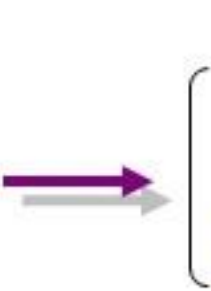

\section{Polimerização}

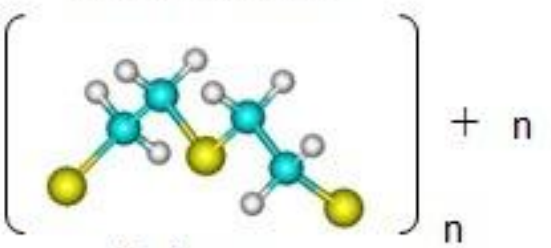

Polímero

Água
O Carbono
- Oxigênio
O Hidrogênio
- Metal
(I) ou (II)

Figura 3.8 - Ilustração das reações envolvidas na técnica dos citratos $(20,37,81)$. 
A técnica dos citratos é uma técnica química que envolve fase líquida, e mantém a homogeneidade da solução aquosa dos sais no gel e no produto óxido sólido final, podendo oferecer vantagens significativas na produção de óxidos dopados com alta homogeneidade ${ }^{(37,81,)}$.

O cátodo compósito constituído de LSCF e CGO pode ser obtido por diferentes rotas de síntese, como mistura de sólidos, precursor polimérico com suspensão coloidal, entre outras ${ }^{(56)}$. A técnica de mistura de sólidos foi adotada por apresentar baixo custo de fabricação, fácil manipulação e boa reprodutibilidade, sendo uma técnica convencional de mistura de materiais cerâmicos particulados ${ }^{(8,82)}$.

\subsection{Processamento cerâmico}

Os materiais cerâmicos têm proporcionado avanços importantes em diversos setores, abrangendo áreas desde as mais tradicionais, como a de revestimentos cerâmicos, até indústrias de alta tecnologia nas áreas de comunicação e informática ${ }^{(82)}$.

O processamento cerâmico é de fundamental importância, tendo como objetivo desenvolver um produto adequado, que possibilite conferir utilidade às propriedades intrínsecas do material de interesse ${ }^{(82)}$. A Figura 3.9 ilustra as principais etapas envolvidas no processamento de materiais cerâmicos.

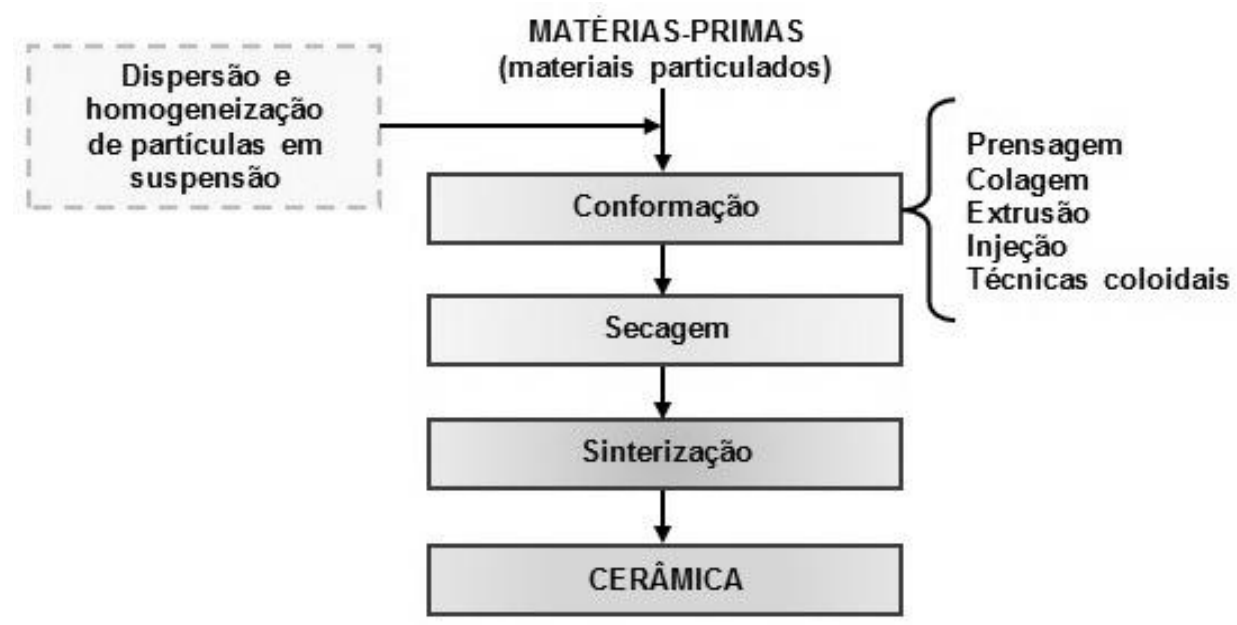

Figura 3.9 - Fluxograma do processamento de materiais cerâmicos ${ }^{(82)}$. 
A conformação é realizada a partir de sistemas envolvendo materiais particulados, na qual o produto final é obtido por meio da movimentação e organização espacial dessas partículas ${ }^{(8,82)}$.

O processamento de sistemas particulados é influenciado por vários fatores que dificultam a etapa de conformação, como por exemplo, forças de capilaridade, rugosidade, formato das partículas, forças superficiais, entre outros. A dificuldade maior é a formação de aglomerados entre as partículas, geradas por forças atrativas de van der Waals, em decorrência da elevada área superficial por unidade de volume. Os aglomerados são minimizados, adicionando às partículas em um meio líquido, formando suspensões que possibilitem sua dispersão e homogeneização, atenuando os efeitos prejudiciais das forças atrativas ${ }^{(82,83)}$.

As suspensões contendo materiais particulados são utilizadas em muitos processos de conformação, como em processos como atomização, impressão, extrusão, moldagem por injeção, entre outros. Estes processos apresentam velocidades de cisalhamentos diferenciados quando aplicados para se obter produtos cerâmicos com dimensões e formas geométricas das mais variadas, devido às características físicas destes materiais, bem como outros parâmetros como estabilidade das suspensões e temperatura de aplicação no processo e secagem. Na Tabela 3.2, são especificadas as diferentes velocidades de cisalhamento típicas para diferentes processos de conformação cerâmica de acordo com a literatura técnica ${ }^{(36,37,84)}$.

Tabela 3.2 - Velocidades de cisalhamento típicas dos principais processos de conformações dos materiais cerâmicos ${ }^{(84)}$.

\begin{tabular}{lc}
\hline \multicolumn{1}{c}{ Processo de conformação } & Velocidade de cisalhamento $\left(\mathrm{s}^{-1}\right)$ \\
\hline \hline Atomização, impressão ou pintura & $10^{3}-10^{4}$ \\
Moldagem por injeção & $10^{2}-10^{4}$ \\
Extrusão & $10^{2}-10^{3}$ \\
Agitação, bombeamento ou mistura & $10^{1}-10^{3}$ \\
Colagem em fita ou imersão & $10^{1}-10^{2}$ \\
Moldagem por injeção a baixa pressão & $10^{1}-10^{2}$ \\
Colagem por filtração & inferior a $10^{1}$ \\
\hline
\end{tabular}

Os estudos envolvendo suspensões cerâmicas são necessários para compreender as propriedades reológicas, fazendo com que as etapas do processo tenham um controle adequado ${ }^{(83,84)}$. 


\subsection{Reologia de suspensões cerâmicas}

Uma das etapas de importância na área de materiais cerâmicos é o seu processamento, envolvendo desde a preparação das matérias primas até a conformação nos mais diversos métodos e geometrias. O resultado de um processamento cerâmico adequado poderá ser observado após o processo de sinterização, com produtos bem acabados, propriedades uniformes, dimensões adequadas e desempenho significativo na aplicação a que se destina ${ }^{(8,82)}$.

O estudo da reologia insere-se no processamento cerâmico na medida em que influencia nas propriedades finais e que são resultados de um tratamento adequado dos materiais durante todas as etapas; ou seja, dependentes do controle nas dimensões das partículas, da adequada adição de aditivos, da estabilidade das suspensões, do método de conformação para a geometria de interesse, da resistência dos produtos a verde, da secagem, entre outros. 0 conhecimento destes fatores são decisivos para obter o produto planejado ${ }^{(84)}$.

A reologia é o ramo da mecânica dos fluidos que investiga as propriedades e o comportamento mecânico de corpos que sofrem uma deformação (sólidos elásticos) ou um escoamento (fluidos) devido à ação de uma tensão de cisalhamento. A viscosidade é a propriedade mais conhecida e a única que caracteriza os fluidos conhecidos como newtonianos. A palavra reologia originou do grego rheo (fluxo) e logos (estudo), sugerida pela primeira vez por Bingham e Crawford, para descrever o fluxo, no caso de materiais líquidos e deformação, no caso de materiais sólidos ${ }^{(36 ; 83,84)}$.

Partindo-se do princípio de que todas as substâncias escoam ou deformam se houver forças capazes de produzir este fenômeno, a reologia tem por finalidade predizer a força necessária para causar uma dada deformação ou escoamento num "corpo", ou reciprocamente, predizer a deformação ou o escoamento resultante da aplicação de um dado sistema de forças ${ }^{(84)}$.

Cada cerâmica estudada na reologia possui sua maneira característica de responder às solicitações de deformação. $O$ conhecimento desse comportamento é importante também para os materiais processados em indústrias cerâmicas, onde através da extrusão, prensagem ou colagem de barbotinas, são requeridas condições específicas altamente dependentes do comportamento reológico ${ }^{(83,84)}$. 
No momento em que um sólido ou líquido é disperso como pequenas partículas (sólido) ou gotículas (líquido), numa fase líquida contínua, ocorrem fenômenos de química de superfície ocasionando a dispersão das partículas ou gotículas na fase líquida. Quando as partículas são sólidas e a concentração de sólidos é relativamente alta, denomina-se suspensão ou pasta. Quando as partículas são líquidas, denomina-se emulsão ${ }^{(83)}$.

No estudo reológico, os parâmetros importantes são: viscosidade, taxa de cisalhamento, concentração de sólidos presentes, e meios utilizados. A variação destes fatores é necessária na medida em que as condições exigidas para cada processo de conformação também variam ${ }^{(83,84)}$.

Todos os fluidos cujo comportamento segue a Lei de Newton, ou seja, a relação entre a tensão de cisalhamento (força cisalhante por área) e gradiente local de velocidade, definido através de uma relação linear, onde a constante de proporcionalidade é chamada de viscosidade do fluido, são chamados "fluidos newtonianos". Todos os gases e a maior parte dos líquidos não poliméricos e homogêneos seguem essa teoria ${ }^{(84)}$.

A viscosidade é uma propriedade apenas do tipo de fluido, dependente da temperatura, pressão e composição do mesmo, não variando com a taxa de cisalhamento e sendo constante com o tempo de cisalhamento. A Tabela 3.3 informa as viscosidades típicas de alguns materiais e substâncias comumente empregadas em diferentes setores de atividade ${ }^{(84)}$.

Tabela 3.3 - Viscosidades de materiais empregados em diferentes setores ${ }^{\left({ }^{84}\right)}$.

\begin{tabular}{lc}
\hline \multicolumn{1}{c}{ Material } & Viscosidade típica $\left(\mathrm{Pa}^{*} \mathrm{~S}\right)$ \\
\hline \hline Vidro soda-cal & superior a $10^{20}$ \\
Vidro fundido $\left(500^{\circ} \mathrm{C}\right)$ & $10^{12}$ \\
Asfalto & $10^{8}$ \\
Polímeros fundidos & $10^{3}$ \\
Mel & $10^{2}$ \\
Caramelo & $10^{1}$ \\
Glicerol & $10^{0}$ \\
Azeite de oliva & $10^{-1}$ \\
Água & $10^{-3}$ \\
Ar & $10^{-5}$ \\
\hline
\end{tabular}


Com relação aos fluidos newtonianos, a tensão no líquido cai para zero imediatamente após o fim da força atuante e, em qualquer cisalhamento subsequente, qualquer que seja o período entre as medidas, a viscosidade sempre será a mesma daquela medida anteriormente. Alguns exemplos de fluido newtonianos são: gases, água, leite, soluções de sacarose e óleos vegetais ${ }^{(83,84)}$.

Entretanto, existem comportamentos diferentes do apresentado acima e que são normalmente denominados de "fluidos não newtonianos". Estes comportamentos são divididos em três tipos: independentes do tempo; dependentes do tempo; e viscoelásticos ${ }^{(83)}$. Os fluidos independentes do tempo são queles que não necessitam de uma tensão de cisalhamento inicial para começar a escoar e, os dependentes do tempo, necessitam dessa tensão de cisalhamento inicial para escoarem. Os fluidos viscoelásticos são um caso em particular e que será discutido no decorrer deste texto ${ }^{(84)}$.

Alguns fluidos (nem todo fluído é uma suspensão), quando em repouso, apresentam um estado desordenado e, quando submetidos a uma tensão de cisalhamento, suas moléculas tendem a se orientar na direção dessa tensão. Quanto maior a tensão aplicada, maior será a ordenação. Com o aumento da taxa de cisalhamento a viscosidade decresce de um valor máximo, constante, chamado de viscosidade de cisalhamento zero para depois voltar a ser constante com a taxa de cisalhamento; ou seja, quanto maior a agitação, ou tensão aplicada, menor a viscosidade. Esses tipos de fluidos não necessitam de uma tensão de cisalhamento inicial para iniciar o escoamento e são denominados de pseudoplásticos ou fluidificantes ${ }^{(84,85)}$. A característica de pseudoplasticidade pode ocorrer em decorrência de três fatores principais:

- Partículas assimétricas no meio líquido que, estando em repouso e de forma aleatória, assumem a orientação na direção do escoamento;

- Sistemas líquidos constituídos de moléculas longas que passam de uma configuração aleatoriamente enrolada para uma orientação na direção do escoamento, assumindo uma forma quase linear (polímeros);

- Presença de moléculas que, em repouso, se encontram altamente solvatadas e possuem camadas destruídas pela ação do cisalhamento.

Para compreender melhor na prática este tipo de comportamento reológico, polpas de frutas e caldos de fermentação são alguns exemplos de produtos que apresentam a característica de fluidos pseudoplásticos ${ }^{(84,85)}$. 
Os fluidos que aumentam sua viscosidade com o aumento da taxa de cisalhamento são denominados de dilatantes ou espessantes. O termo dilatância foi conferido por Reynold durante observação de uma suspensão de areia em água ${ }^{(84)}$. É um fenômeno relativamente comum em materiais que contenham mais de uma fase, sendo bastante rara a ocorrência em polímeros.

Quando em repouso ou submetida a movimentos lentos, a mistura comporta-se como um líquido, mas se torna bastante viscosa, quase sólida, quando pressionada ou batida abruptamente. Um tradicional exemplo de fluido dilatante é a interessante mistura de amido de milho e água ${ }^{(84)}$.

Alguns fluidos necessitam da aplicação de uma tensão de cisalhamento inicial para que haja deformação escoamento. Esse comportamento é consequência de uma estrutura interna que impede a movimentação. Após a aplicação da tensão, a estrutura colapsa se deformação. Dentre estes estão ${ }^{(84,85)}$ :

- Plásticos de Bingham: possuem uma relação linear entre a tensão de cisalhamento e a taxa de deformação, a partir de uma tensão inicial;

- Herschel-Burkley: Este caso é semelhante ao modelo anterior, mas a relação entre a tensão e a taxa de deformação não é linear e é dependente de um índice adimensional característico de cada substância.

A Figura. $3.10^{(36)}$ ilustra graficamente, relacionando a tensão de cisalhamento em função da taxa de deformação, o comportamento característico típico dos principais tipos de fluidos que são independentes da variável tempo.

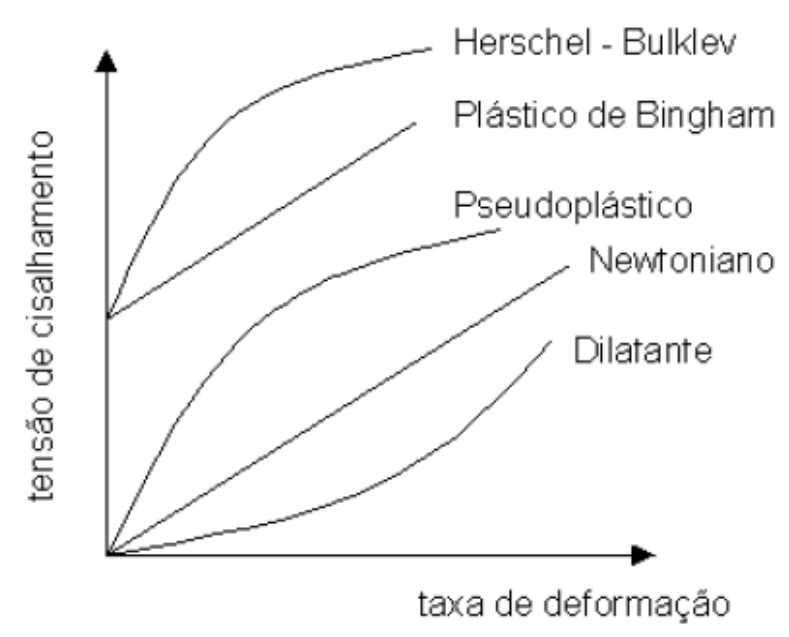

Figura 3.10 - Gráfico representativo dos fluidos independentes do tempo ${ }^{(36)}$. 
Existe outro grupo de fluidos onde a propriedade viscosidade diminui com o tempo de aplicação da tensão, voltando a ficar mais viscoso quando a aplicação da força termina. Esses fluidos são denominados de tixotrópicos. Como principais exemplos de fluidos tixotrópicos têm-se suspensões concentradas, emulsões, soluções proteicas, petróleo cru e tintas ${ }^{(36,84 ; 85)}$.

Um comportamento particular, mas inverso ao caso anterior (tixotropia) também pode ocorrer. Nestes fluidos a viscosidade é aumentada com o tempo de aplicação da tensão, voltando a ficar menos viscoso quando a aplicação da força termina. Esses fluidos são denominados anti-tixotrópicos ou reopéxicos. Um bom exemplo é a argila bentonita ${ }^{(36,84 ; 85)}$.

A Figura. $3.11^{(36)}$ ilustra graficamente, o comportamento característico típico dos principais tipos de fluidos que são dependentes do tempo.

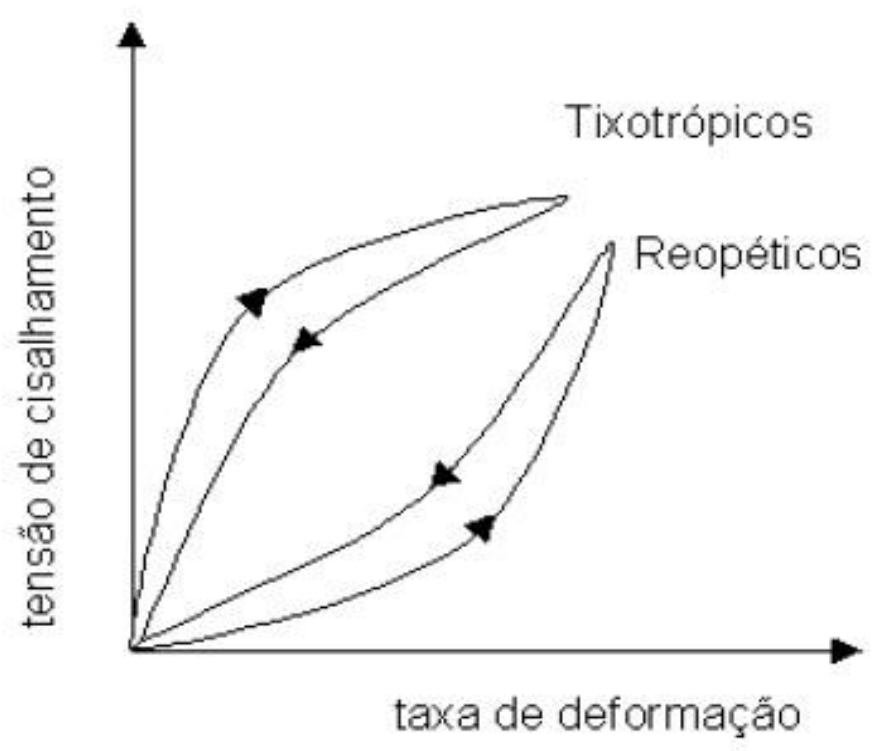

Figura 3.11 - Gráfico representativo dos fluidos dependentes do tempo ${ }^{(36)}$.

Um último grupo são os fluidos viscoelásticos, que apresentam um comportamento intermediário entre o comportamento "Hookeano" (elástico ideal) e o comportamento "Newtoniano" (fluido ideal). Esses fluidos são substâncias que apresentam propriedades viscosas e elásticas acopladas. Quando cessa a tensão de cisalhamento ocorre certa recuperação da deformação ${ }^{(36,84)}$. 
Para simplificar o comportamento reológico particular de cada grupo ou tipo de fluido conhecido, com suas características reológicas mais comuns, a Tabela $3.4^{(84)}$ contém as principais equações referentes aos modelos reológicos considerados mais frequentes em Reologia ${ }^{(36 ; 84 ; 85)}$.

Tabela 3.4 - Modelos reológicos mais frequentes ${ }^{(84)}$.

\begin{tabular}{cc}
\hline Modelo reológico & Equação principal \\
Bingham & $\sigma=\eta \dot{\gamma}$ \\
Ostwald-de Waele & $\sigma=\sigma_{0}+\eta_{p} \dot{\gamma}$ \\
Herschel-Bulkley & $\sigma=K(\dot{\gamma})^{n}$ \\
Herschel-Bulkley modificado & $\sigma=\sigma_{0}+K_{1}(\dot{\gamma})^{n}$ \\
Casson & $\sigma^{n_{1}}=\left(\sigma_{0}\right)^{n_{1}}+K_{1}(\dot{\gamma})^{n_{2}}$ \\
Casson modificado & $\sigma^{1 / 2}=\sigma_{0}{ }^{1 / 2}+K_{1}(\dot{\gamma})^{1 / 2}$ \\
Ellis & $\sigma^{1 / 2}=\sigma_{0}{ }^{1 / 2}+K_{1}(\dot{\gamma})^{n_{1}}$ \\
Cross & $\dot{\gamma}=K_{1} \sigma+K_{2}(\sigma)^{n_{1}}$ \\
Carreau & $\frac{\eta_{0}-\eta}{\eta-\eta_{\infty}}=(K \dot{\gamma})^{m}$ \\
Séries de potência & $\frac{\eta-\eta_{\infty}}{\eta_{0}-\eta_{\infty}}=\frac{1}{\left(1+\left(K_{1} \dot{\gamma}\right)^{2}\right)^{m_{1 / 2}}}$ \\
& $\sigma=K_{1} \sigma+K_{2} \sigma^{3}+K_{3} \sigma^{5} \ldots$ \\
\hline
\end{tabular}

Nota: $\boldsymbol{\sigma}$ é a tensão de cisalhamento, $\boldsymbol{\sigma}_{\mathbf{0}}$ é a tensão de escoamento, $\boldsymbol{\eta}$ é a viscosidade, $\boldsymbol{\eta}_{\boldsymbol{p}}$ é a viscosidade plástica, $\boldsymbol{\eta}_{\mathbf{0}}$ é a viscosidade limite extrapolada para uma velocidade de cisalhamento igual a zero, $\boldsymbol{\eta}_{\infty}$ é a viscosidade limite extrapolada para uma velocidade de cisalhamento infinita, $\dot{\gamma}$ é a taxa de cisalhamento e $\boldsymbol{m}_{\boldsymbol{i}}$ é um parâmetro adimensional (neste caso $\boldsymbol{i}=\frac{\mathbf{1}}{\mathbf{2}}$ ).

$K_{1}, K_{2}, K_{3}, n_{1}$ e $n_{2}$ são constantes arbitrárias e índices de potências, respectivamente, determinados mediante resultados experimentais. 


\subsection{Suspensões cerâmicas coloidais}

Suspensões coloidais são misturas de pelo menos duas fases, com a matéria de uma fase na forma finamente dividida (sólido, líquido ou gás), denominada fase dispersa e misturada com a contínua (sólido, líquido ou gás), denominada meio de dispersão ${ }^{\left({ }^{83}\right)}$. Essa ciência se ocupa com sistemas nos quais um ou mais componentes possuem pelo menos uma de suas dimensões entre $1 \mathrm{~nm}$ (nanômetro) a $1 \mu \mathrm{m}$ (micrometro) e interagem com o meio ${ }^{(83 ; 86)}$.

Atualmente existe nomenclatura para separar em grupos, diferentes tipos de sistemas contendo partículas coloidais. Os sistemas denominados de "nano coloidais" possuem seus componentes com menos de 0,1 $\mu \mathrm{m}$. Quando possuem um ou mais componentes com tamanhos médios de partículas entre 0,1 e $5 \mu \mathrm{m}$, são chamados de "micro coloidais". Por fim, quando possuem um ou mais componentes com mais de $5 \mu \mathrm{m}$, são conhecidos como "macro coloidais" (86).

Os sistemas coloidais podem ser tão concentrados como uma pasta ou mesmo um cimento ou tão diluídos como os que turvam semelhantes a águas de lagos. A água natural ou tratada, o leite, o vinho, as argilas, as tintas, o papel e alguns grupos de produtos farmacêuticos são bons exemplos de sistemas coloidais. As suspensões coloidais geralmente são aquosas, ainda que, também possam ser utilizados meios não aquosos (geralmente em álcool) ${ }^{(83,84)}$.

Em cada caso, as propriedades físico-químicas e qualidades das suspensões são fortemente afetadas pelas propriedades dos colóides. Podemos mudar as características de uma suspensão ao compreender as interações de um colóide individual com outro. Para produzir suspensões estáveis, as forças repulsivas entre os colóides devem ser maximizadas para que as repulsões mútuas entre as partículas adjacentes impeçam a união dos colóides e evitem a sedimentação devido à formação de aglomerados ${ }^{(83 ; 84)}$.

Um dos maiores efeitos das superfícies são os fenômenos eletrocinéticos, pois cada colóide contém uma carga elétrica que geralmente é negativa, ainda que também possa ser positiva. Estas cargas produzem forças de repulsão eletrostática entre os colóides vizinhos. Se a carga é suficientemente elevada os colóides permanecem discretos, dispersos e em suspensão Quando se reduzem ou eliminam estas cargas, obtém-se o efeito oposto e se aglomeram, ocorrendo sedimentação ${ }^{(83 ; 84)}$. 
O modelo da dupla camada elétrica (Figura 3.12) ilustra uma representação visual da atmosfera iônica na proximidade da partícula carregada e como atuam as forças de repulsão. É possível entender este modelo como uma sequência de etapas que ocorrem ao seu redor ${ }^{\left({ }^{(8)}\right)}$.

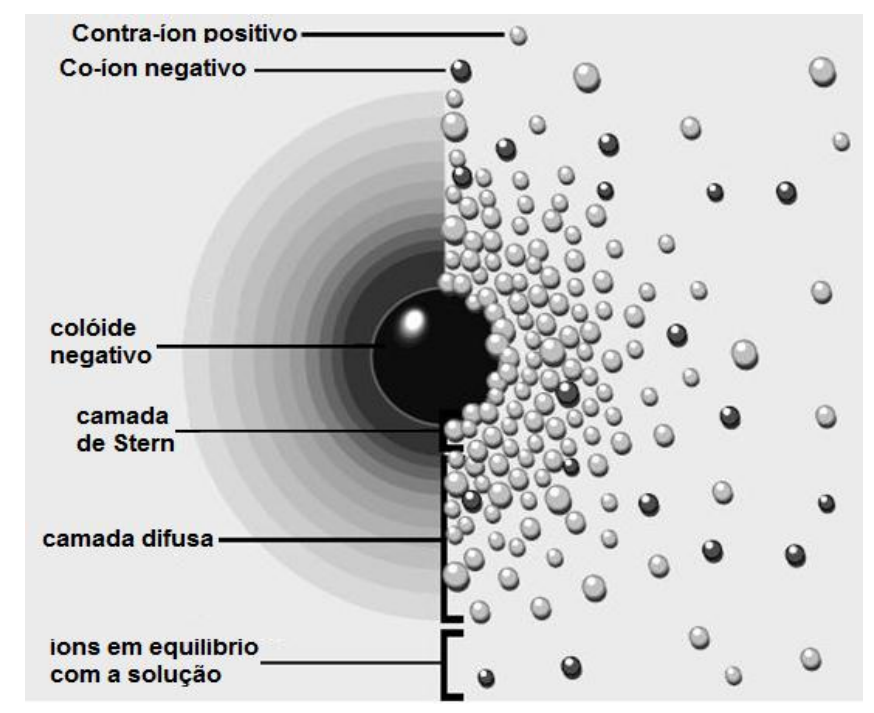

Figura 3.12 - Ilustração representativa da dupla camada elétrica ${ }^{(83)}$.

Inicialmente ocorre o efeito do colóide sobre o íon positivo (chamado de contra íon) na solução. A atração do colóide com carga negativa faz com que alguns íons positivos formem uma "capa" rígida adjacente ao redor da superfície do colóide. Esta capa de contra íons é conhecida como camada de Stern ${ }^{(83 ; 84)}$.

Após a formação da Camada de Stern, os íons positivos adicionais são atraídos pelo colóide negativo, mas repelidos pela Camada de Stern, como também por outros íons positivos que se aproximam. Este equilíbrio resulta na formação da camada difusa, contendo contra íons ${ }^{(83 ; 84)}$.

Em decorrência desse fenômeno, existe uma alta concentração de contra-íons perto da superfície, a qual diminui gradualmente com a distância, até que atinja o equilíbrio no meio da solução ${ }^{(83 ; 84)}$.

De forma similar, ainda que oposta, na dupla camada difusa existe uma limitação de íons negativos, chamados co-íons, pois possuem a mesma carga que o colóide. Sua concentração aumenta gradualmente ao afastar-se do colóide, enquanto que as forças repulsivas do próprio colóide são compensadas pelos íons positivos, até alcançar novamente o seu estado de equilíbrio ${ }^{(83 ; 84)}$. 
A camada difusa pode ser visualizada como uma atmosfera carregada rodeando o colóide. A qualquer distância da superfície, a densidade de carga é igual à diferença de concentração entre íons positivos e negativos. A densidade de carga é muito maior perto do colóide e gradualmente diminui a zero quando as concentrações de íons positivos e negativos se assemelham. Os contra-íons da camada de Stern e da camada difusa são o que juntos conhecemos como "dupla camada elétrica". A espessura desta dupla camada depende do tipo e concentração dos íons na solução ${ }^{(83 ; 84)}$.

O colóide negativo e sua atmosfera carregada positivamente produzem um potencial elétrico relativo à solução. Este potencial possui um valor máximo na superfície e diminui gradualmente com a distância, aproximando-se de zero fora da camada difusa. A queda do potencial e a distância até o colóide é um indicador da força repulsiva entre os colóides ${ }^{(83 ; 84)}$.

Um ponto de particular interesse é o potencial onde se unem a camada difusa e a de Stern. Este potencial é conhecido como "potencial zeta"; o qual é importante porque pode ser medido de uma maneira muito simples, enquanto que a carga da superfície e seu potencial não podem ser medidos ${ }^{(84)}$.

O potencial zeta é determinado a partir da relação HelmholtzSmoluchowski, entre a velocidade da partícula e o campo elétrico aplicado e é conhecida como "mobilidade eletroforética". O potencial zeta pode ser uma maneira efetiva de controlar o comportamento do colóide, pois indica mudanças no potencial da superfície e nas forças de repulsão envolvidas. Quanto maior o potencial zeta mais provável que a suspensão seja estável, pois as partículas carregadas se repelem umas às outras, superando a tendência natural à agregação. A medida do potencial zeta é com frequência a chave para compreender processos de dispersão e agregação em aplicações tão diversas quanto à purificação de água, tintas, fármacos e suspensões cerâmicas ${ }^{(83 ; 84)}$.

A teoria DLVO (chamada assim por Derjaguin, Landau, Verwey e Overbeek) é a clássica explicação das partículas em suspensão. Essa teoria se sustenta no equilíbrio entre as forças opostas de repulsão eletrostática e as forças de atração do tipo van der Waals, além de explicar que algumas partículas se aglomeram em decorrência da atuação dessas forças envolvidas ${ }^{(83 ; 84)}$. 
A repulsão eletrostática é importante quando os colóides se aproximam, pois as duplas camadas começam a interferir uma sobre a outra no sistema. Em decorrência disso, é necessária uma energia para sobrepor a repulsão e forçar a união entre as partículas. Esta energia aumenta fortemente quando as partículas se aproximam. Por este motivo utiliza-se uma curva de repulsão eletrostática para indicar a quantidade de energia que há de ser vencida para que as partículas possam ser forçadas a aglomeração. A energia alcança um valor máximo quando as partículas estão muito próximas e chega a zero quando estão fora das duplas camadas elétricas, sendo que seu valor máximo está relacionado com o potencial elétrico da sua superfície ${ }^{(83 ; 86)}$.

A atração de van der Waals entre os colóides é o resultado das forças entre as moléculas individuais. O efeito é aditivo; ou seja, uma molécula do primeiro colóide experimenta a atração de van der Waals de cada molécula do segundo colóide. Isto se repete para cada molécula do primeiro colóide e a força total corresponde à soma de todas as forças parciais ${ }^{(83 ; 84)}$.

Dependendo dos objetivos, é possível alterar a superfície do colóide para aumentar ou diminuir a barreira energética. Vários métodos podem ser usados, tais como mudanças na atmosfera iônica, no $\mathrm{pH}$ ou agregando compostos ativos para afetar diretamente a carga do colóide. Em cada caso, a medida de potencial zeta indicará o efeito da alteração em sua estabilidade ${ }^{(83 ; 84)}$.

\subsection{Estabilidade das suspensões cerâmicas}

Os fenômenos pelos quais ocorre a estabilização das suspensões em geral são: a estabilização eletrostática, a estérica e a eletroestérica ${ }^{(83 ; 84)}$.

O objetivo do método de estabilização eletrostática é aumentar as forças repulsivas entre as partículas para evitar a ocorrência do fenômeno de aglomeração. A estabilização eletrostática está baseada no desenvolvimento de cargas superficiais. As superfícies das partículas sólidas tem grande número de ligações atômicas insaturadas, podendo criar novas ligações com espécies presentes na suspensão. Estas espécies podem ser íons hidroxônio $\left(\mathrm{H}_{3} \mathrm{O}^{+}\right)$, hidroxila $\left(\mathrm{OH}^{-}\right)$ou qualquer outro presente na suspensão ${ }^{(83 ; 84)}$. 
No caso de íons hidroxônio, ocorre hidratação e no caso de hidroxila ocorre hidroxilação. Quem determina qual processo irá ocorrer é o valor do $\mathrm{pH}$ do meio liquido, sendo que a hidroxilação acontece quando o meio liquido é básico e a hidratação quando o mesmo é acido ${ }^{(83)}$.

Em seguida, o processo envolvido gera potencial elétrico na superfície das partículas, positivo no caso de reações com íons hidroxônio e negativo no caso de reações com hidroxila. Esse potencial atrai grande quantidade de íons de carga contrária (contra-íons). Em função do tamanho dos contra-íons, apenas um número limitado poderá ser adsorvido na superfície das partículas sólidas ${ }^{\left({ }^{(8)} \text {. }\right.}$

Nas partículas com dupla camada elétrica, atuam forças eletrostáticas repulsivas que são responsáveis pela obtenção de suspensões cerâmicas dispersas. É desejável obter duplas camadas elétricas de maior espessura para evitar a aproximação de partículas que possam causar a predominância de forças atrativas de van der Waals e, consequentemente, gerar aglomeração. $O$ aumento da valência e da concentração de contra-íons (ou seja, o aumento das forças iônicas) causam a redução da espessura da dupla camada elétrica ${ }^{(83 ; 84)}$.

A estabilização estérica se baseia na adsorção de polímeros na superfície das partículas. Essa adsorção ocorre quando há alguma afinidade entre a estrutura do polímero e a superfície da partícula, por atração de forças de van der Waals ou ligações de hidrogênio. A estabilização ocorre porque as cadeias poliméricas impedem que as partículas se aproximem entre si por impedimento estérico, barrando o efeito de atração das partículas por essas forças ${ }^{\left({ }^{(83} ; 84\right)}$.

A estabilização eletroestérica é semelhante aos dois fenômenos citados anteriormente, porém são utilizados polímeros iônicos que apresentam uma longa "cauda" polimérica e uma extremidade com carga iônica, que são adsorvidas na superfície da partícula. Esta extensão com carga causa o efeito de impedimento estérico e eletrolítico que estabiliza a suspensão ${ }^{(83 ; 84)}$.

\subsection{Conformação a partir de suspensões cerâmicas}

Muitos processos são usados para conformar peças cerâmicas a partir de suspensões com baixa, média ou elevada concentração de sólidos, como a colagem a partir de barbotinas, em fita ou com ação de pressão, extrusão, injeção em moldes, eletroforese, deposição por spray, entre outros ${ }^{(8 ; 36 ; 37)}$. 
Cada um destes processos de conformação sofre influência distinta de fatores que envolvem tanto as características dos materiais (tamanho de partículas, distribuição de tamanho de partículas, estado de agregação, tipo de ligação, densidade) como dos parâmetros específicos de cada processamento, como estabilidade e reologia das suspensões, temperatura, aspectos cinéticos de conformação, dimensões e forma da peça a ser conformada ${ }^{(7 ; 8)}$.

\subsection{Sinterização}

A sinterização pode ser descrita como um processo nos quais particulados cristalinos ou não, na forma de compactados, são tratados termicamente em uma temperatura usualmente acima da metade da temperatura de fusão, envolvendo alteração da microestrutura, por meio de um ou mais mecanismos de transporte de massa, produzindo único sólido homogêneo ${ }^{(8 ; 87)}$.

Durante todo o processo de sinterização no estado sólido (na sinterização pode haver também fase líquida), as reações são termicamente ativadas, onde ocorrem espontaneamente quando uma determinada temperatura é atingida. As reações ocorrem em amplo intervalo de temperatura e entre as partículas em contato. Neste último caso, não só a temperatura, mas também o tamanho de partícula, além da área de contato, são variáveis a considerar ${ }^{(7 ; 8 ; 87)}$.

$\mathrm{Na}$ produção de cerâmicas à base de terras raras, um fenômeno importante é a sinterização no estado sólido. Este evento é preferível na produção de cerâmicas com adequadas propriedades mecânicas e/ou elétricas. Neste caso, os constituintes do material em forma de particulados, posteriormente compactado, permanecem sólidos durante todo o processo ${ }^{(7 ; 8)}$.

A densificação máxima do material é atingida pela mudança na forma das partículas constituintes, pois cada partícula pode possuir vários gráos. A variável mais importante da sinterização é a redução da energia livre de superfície do sistema, ou seja, a tendência do sistema em atingir o estado de menor energia livre, onde ocorre uma redução nas áreas das superfícies dos compactados e na transformação de partículas pequenas em maiores, ocasionando o crescimento de grão e a substituição das interfaces gás-sólido, por sólido-sólido de maior energia, no caso de materiais cerâmicos ${ }^{(8 ; 87)}$. 
O estudo da sinterização é geralmente simplificado, assumindo que o processo ocorre em três estágios: inicial, intermediário e final (Figura $3.13^{(88)}$ ).

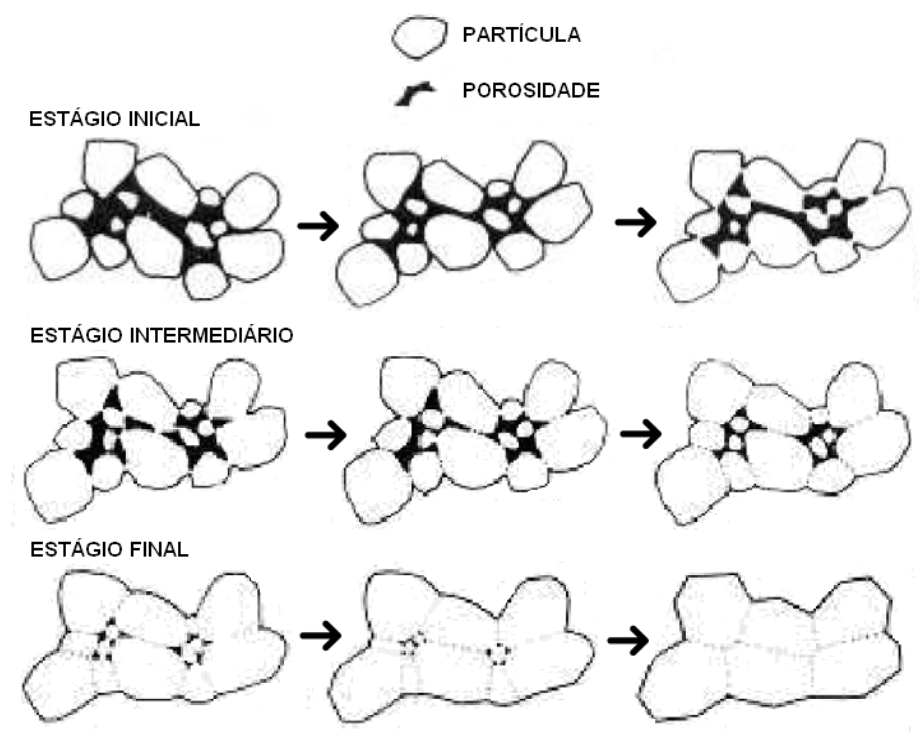

Figura 3.13 - Representação ilustrativa dos principais estágios da sinterização ${ }^{(88)}$.

Não existe diferenciação clara entre os três estágios e alguns autores chegam a omitir o estágio intermediário. Vários modelos têm sido propostos com a finalidade de determinar os mecanismos, responsáveis pela sinterização ${ }^{(88)}$.

Todavia, a teoria mais aceita afirma que, no estágio inicial, ocorre o rearranjo das partículas e início da formação de "pescoços" entre os pontos de contato. Este rearranjo consiste em leves movimentos ou rotações das partículas adjacentes, causando um aumento no número de pontos de contato. No primeiro estágio a porosidade é relativamente grande. No segundo estágio há uma redução na porosidade e a sinterização faz com que os centros de massa das partículas iniciais se aproximem. No terceiro estágio ocorre à remoção da porosidade em função do sinterização. Durante todo o processo, ocorre por difusão, o mecanismo de transporte de massa ao longo dos contornos de grão. Entretanto, como o cátodo necessita possuir porosidade, a sinterização deve ser controlada para que não ocorra a eliminação dessa porosidade requerida ${ }^{(87 ; 89)}$.

O crescimento de grão ocorre em todos os estágios do processo de sinterização. O modelo mais simples e mais aceito de crescimento de grão considera o movimento dos contornos de grão, que é inversamente proporcional ao tamanho médio do grão ${ }^{(87)}$. 
Dessa forma, a segregação de impurezas nos contornos de grão pode reduzir a energia livre do sistema e, consequentemente, diminuir a taxa de crescimento do grão, influenciando diretamente na sinterização ${ }^{(87)}$.

O óxido misto constituído de lantânio, estrôncio, cobalto e ferro não possui estudos suficientes em termos de de sua cinética de sinterização e, raramente se encontram trabalhos onde os modelos são aplicados ou propostos especificadamente para a sinterização deste óxido misto, sendo a ênfase dada no estudo da otimização dos processos de sinterização ${ }^{(89)}$.

\subsection{Técnicas de processamento cerâmico}

No processamento de materiais cerâmicos tradicionais ou avançados, mais especificamente para componentes das SOFCs, é necessário conhecer quais técnicas são adequadas para aplicação nas diferentes configurações da célula unitária para preparação de substratos e deposição das camadas na forma de filmes com espessuras micrométricas ${ }^{(90 ; 91 ; 92)}$.

As configurações da célula unitária são muitas vezes classificadas como "auto-suporte", nas quais o cátodo, o eletrólito, ou ânodo é um componente estrutural do módulo; ou configuração suporte externo, cujas camadas da ordem de micrômetros de cátodo, eletrólito e/ou ânodo são suportadas sobre 0 interconector ou em um substrato poroso ${ }^{(2,12)}$, como ilustra a Figura $3.14^{(37)}$.
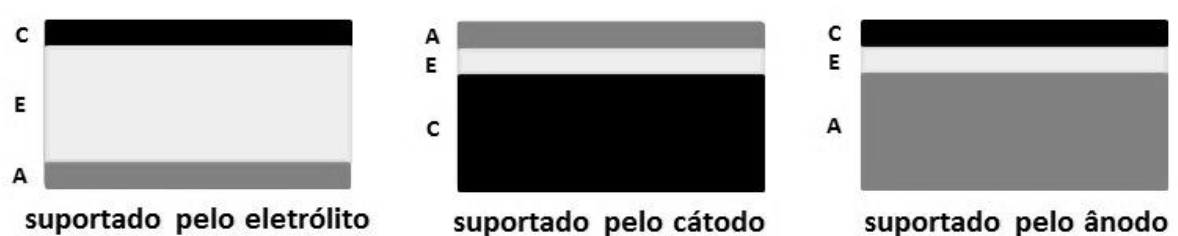

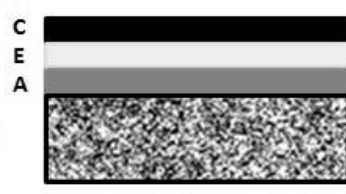

suportado por um substrato poroso

Cátodo

Substrato poroso suportado pelo cátodo suportado pelo ânodo

Figura 3.14 - Principais configurações da célula unitária ${ }^{(37)}$. 
As técnicas de processamento para preparação de substratos e deposição de camadas micrométricas dos componentes cerâmicos dependem do projeto da SOFC, com espessuras usualmente na faixa de 50 a $1000 \mu \mathrm{m}$, sendo entre 50 a $200 \mu \mathrm{m}$ para camadas e substratos, respectivamente ${ }^{(12)}$.

Cada técnica de processamento possui suas vantagens e desvantagens, geralmente associadas com custo e disponibilidade. As diversas técnicas utilizadas para a formação dessas camadas são: recobrimento por imersão (dip coating), moldagem a seco (dry pressing), deposição eletroquímica a vapor (electrochemical vapor deposition - EVD), eletroforese (electrophoresis), impressão em tela (screen printing), recobrimento por rotação (spin coating), recobrimento por nebulização (spray coating), spray pirólise (spray pyrolysis), plasma (sputtering), moldagem por extrusão (extrusion molding), calandragem de fita (tape calandering), colagem de fita (tape casting), deposição por spray (wet powder spraying), entre outras menos utilizadas $(7 ; 8 ; 36 ; 37 ; 38)$.

Alguns autores, como Darbandi et al. (91) utilizaram a técnica de recobrimento por rotação (spin coating) para a deposição de camadas micrométricas dos óxidos mistos de $\left(\mathrm{La}_{0,60} \mathrm{Sr}_{0,40}\right)\left(\mathrm{Co}_{0,20} \mathrm{Fe}_{0,80}\right) \mathrm{O}_{3-\delta}$ - LSCF, $\left(\mathrm{La}_{0,25} \mathrm{Ba}_{0,25} \mathrm{Sr}_{0,5}\right)\left(\mathrm{Co}_{0,2} \mathrm{Fe}_{0,8}\right) \mathrm{O}_{3-\delta}$ - LBSCF e compósito contendo CGO sobre substrato de CGO com espessura de aproximadamente $200 \mu \mathrm{m}$.

Os pesquisadores Liang et al. ${ }^{(93)}$ estudaram o cátodo compósito LSM/YSZ, cuja técnica de deposição foi impressão sobre tela (screen printing) no eletrólito suporte de $\mathrm{YSZ}$ e sinterização a $1200^{\circ} \mathrm{C}$ em ar durante 2 horas.

Segundo Song et al. ${ }^{(76)}$, o filme de cátodo compósito LSM/YSZ possui uma área de $1,4 \mathrm{~cm}^{2}$ com espessura de 25 a $30 \mu \mathrm{m}$. O filme de LSM/YSZ sinterizado a $1100^{\circ} \mathrm{C}$ por 4 horas foi depositado no disco de $\mathrm{YSZ}$ de diâmetro de $20 \mathrm{~mm}$ e espessura de $0,50 \mathrm{~mm}$ e sinterizado a $1400^{\circ} \mathrm{C}$ por 4 horas. A técnica de conformação utilizada neste trabalho também foi impressão sobre tela.

O trabalho de pesquisa dos autores Holtappels e Bagger ${ }^{(94)}$ está relacionado com multicamadas de cátodos. Estas multicamadas são fabricadas com composição gradual de $\left(\mathrm{La}_{0,85} \mathrm{Sr}_{0,15}\right) \mathrm{MnO}_{3-\delta},\left(\mathrm{La}_{0,84} \mathrm{Sr}_{0,16}\right) \mathrm{CoO}_{3-\delta}$ e $3 \%$ em mol de YSZ, estabelecendo uma variação nas camadas entre os distintos materiais. As multicamadas foram depositadas por wet powder spraying sobre substratos de YSZ com $8 \%$ em mol de $\mathrm{YSZ}$ e sinterizada a $1100^{\circ} \mathrm{C}$ por 2 horas. 
Os autores Lee et al. ${ }^{(95)}$ utilizaram a técnica de impressão sobre tela (screen printing) para a deposição de camadas micrométricas dos óxidos mistos de $\left(\mathrm{La}_{0,58} \mathrm{Sr}_{0,42}\right)\left(\mathrm{Co}_{0,20} \mathrm{Fe}_{0,80}\right) \mathrm{O}_{3-\delta}$, além de uma camada intermediária de zircônia estabilizada com escandia - ScSZ sobre substrato de YSZ conseguindo uma resistência a polarização de $0,048 \Omega^{*} \mathrm{~cm}^{2}$ a $750^{\circ} \mathrm{C}$.

Os eletrólitos de CGO ou YSZ têm sido estudados em diferentes condições de processamento cerâmicos, como técnicas de conformação de camadas micrométricas ou por métodos de sinterização para serem utilizados como suporte para as camadas de cátodo e ânodo (45; 46; 96; 97; 98; 99).

Alguns autores ${ }^{(10 ; 11 ; 38)}$ concluíram que para utilizar o eletrólito CGO ou YSZ sobre eletrodo suporte é necessário que este apresente tamanho de grãos submicrométricos, alta condutividade iônica e baixa temperatura de sinterização.

As técnicas mais utilizadas segundo a literatura são calandragem de fita para substratos e impressão sobre tela para camadas em SOFCs com configuração planar. A fabricação e processamento de materiais e componentes têm alcançado um avanço, nos quais as tecnologias estão sendo ajustadas preferencialmente para produção em série e reduções de custos ${ }^{(38 ; 40 ; 100)}$.

A técnica de conformação por wet powder spraying ou deposição por spray úmido ${ }^{(37 ; 101)}$ é uma técnica mais simples e de baixo custo para a fabricação de camadas em superfícies planas e tridimensionais. Consiste no uso de uma suspensão composta de particulados, solventes e aditivos, que é pulverizado pelo bocal de um aerógrafo automático ou manual (Figura 3.15) ${ }^{(37)}$.

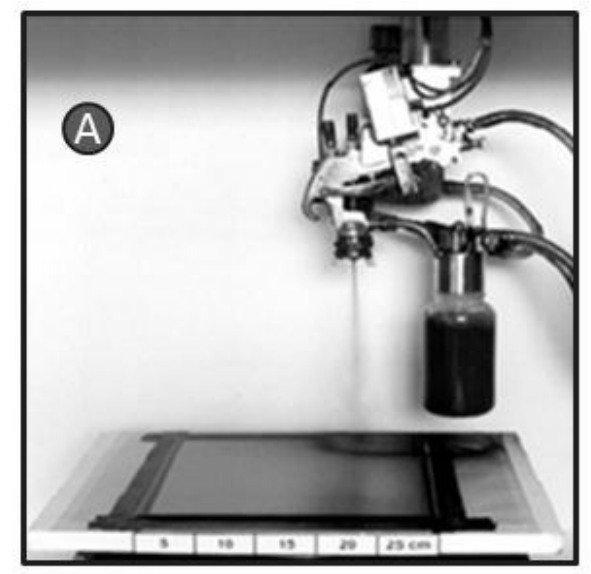

Fonte: http://www.fz-juelich.de/

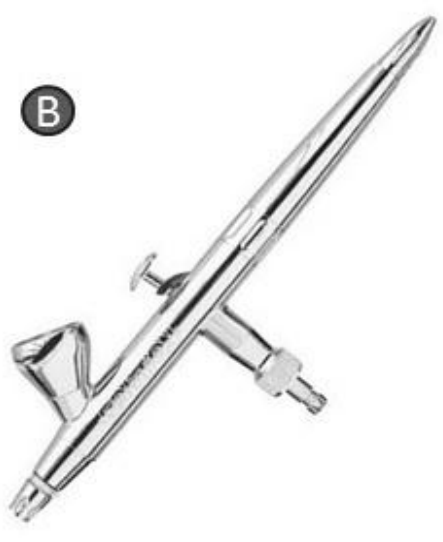

Fonte: http://www.harder-airbrush.de/

Figura 3.15 - Aerógrafo automático (a) e manual (b), para deposições. 
A espessura da camada é controlada pela quantidade de material pulverizado, com posterior etapa de secagem. A espessura obtida pode variar entre 5 e $100 \mu \mathrm{m}$. Os parâmetros do aerógrafo que afetam a formação da camada sobre o substrato são: pressão, distância, tipo do bico, viscosidade, fração de sólidos na suspensão e distribuição granulométrica dos particulados ${ }^{(37 ; 101)}$.

Os passos de secagem intermediários para obter camadas mais espessas são necessários para evitar trincas. As vantagens são o baixo custo de fabricação e a flexibilidade de se obter camadas homogêneas e com espessuras variadas. As limitações desta técnica são o overspray, que é a quantidade de suspensão que é pulverizada para fora do substrato, podendo ser reciclada; e a formação da névoa de suspensão, que necessita ser extraída por sucção ${ }^{(37 ; 101)}$.

O aerógrafo é alimentado com ar comprimido e com a suspensão de interesse. A suspensão é colocada no recipiente (copo) acoplado. Este recipiente varia em diversos modelos de aerógrafos, podendo ser removível ou fixo, lateral ou acoplado na parte superior ou inferior do aerógrafo. A posição dos copos determina se o aerógrafo é alimentado pela suspensão através de sucção (copo abaixo do bico) ou por gravidade (copo acima do bico) ${ }^{(101)}$.

Quando o ar se mistura à suspensão é formado um jato único e homogêneo expelido pelo bico do aerógrafo como uma névoa que deve ser direcionada ao substrato a ser pulverizado. A Figura 3.15 ilustra um aerógrafo automatizado (a) alimentado pela suspensão por sucção e um aerógrafo manual (b) alimentado pela suspensão por gravidade ${ }^{(37 ; 101)}$.

O aerógrafo manual pode ser constituído de ação simples ou também de dupla ação. No aerógrafo de ação simples, o movimento existente no gatilho está limitado ao seu acionamento para baixo, liberando um jato contendo partículas da suspensão e com dimensões pré-determinada, não sendo possível o controle da espessura depositada. No aerógrafo de dupla ação, o gatilho possui duas funções distintas: quando pressionado para baixo, abre a válvula que libera a entrada de ar comprimido e, à medida que se puxa o gatilho para trás (mantendo sempre pressionado), é acionado o mecanismo que libera a saída da suspensão (neste caso, quanto mais para trás se posiciona o gatilho, maior é a liberação de jato) ${ }^{(37 ; 101)}$. A Figura $3.16^{(37)}$ ilustra os aerógrafos de ação simples (Figura 3.16 A) e de dupla ação (Figura 3.16 B1, B2 e B3), para melhor compreensão de seus funcionamentos. 

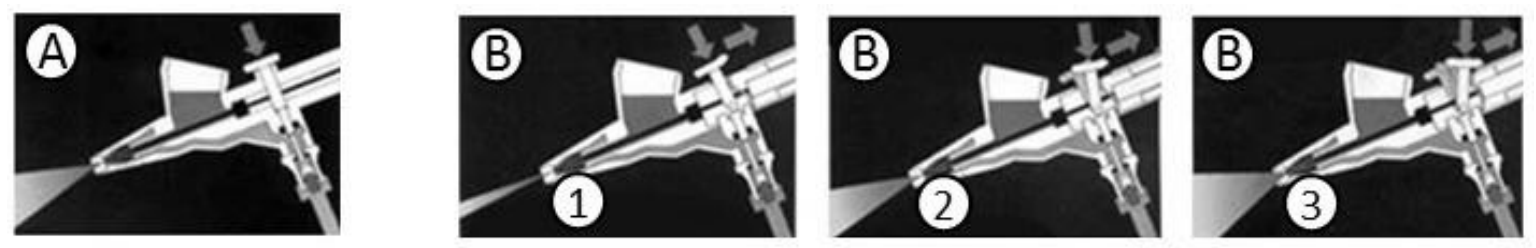

Figura 3.16 - Ilustração dos aerógrafos de ação simples $(A)$ e dupla ação $(B){ }^{(37)}$.

A técnica de wet powder spraying é bastante interessante, pois permite elevado fluxo de deposição de material na forma de particulados, baixo custo de investimento para a fabricação de camadas micrométricas, além de uma fácil alteração da escala com dimensão laboratorial para industrial ${ }^{(37 ; 101)}$.

$\mathrm{Na}$ aplicação com o aerógrafo, parâmetros como velocidade, pressão, distância do substrato e abertura do bocal são importantes, além da utilização de uma suspensão estável durante a aplicação. $\mathrm{Na}$ Tabela 3.5, são fornecidos parâmetros típicos utilizados por esta técnica quando se trabalha com suspensões cerâmicas para deposição de camadas micrométricas ${ }^{(37 ; 101)}$.

Tabela 3.5 - Parâmetros indicados para a técnica por wet poder spraying ${ }^{(37,101)}$.

\begin{tabular}{ll}
\hline \multicolumn{2}{c}{ Parâmetros indicados para o preparo da suspensão cerâmicas } \\
\hline Teor de sólidos & entre 10 e $70 \%$ \\
Viscosidade & $\leq 10 \mathrm{mPas}$ (cerâmica) \\
Tamanho médio de partículas & entre 0,50 e $50 \mu \mathrm{m}$ \\
\hline \multicolumn{1}{c}{ Parâmetros indicados para a utilização do aerógrafo } \\
\hline Distância do substrato & entre 150 e $250 \mathrm{~mm}$ \\
Pressão & entre 0,50 e 2,50 Bar \\
Velocidade & entre 2500 e $9000 \mathrm{~mm} / \mathrm{min}$ \\
Diâmetro do bocal & aproximadamente $2 \mathrm{~mm}$ \\
\hline
\end{tabular}

A técnica de conformação utilizada neste trabalho é wet poder spraying utilizando um aerógrafo de dupla ação, alimentado com suspensão por gravidade. Os cátodos de LSCF e compósitos constituídos da mistura de LSCF com CGO, foram depositados sobre substratos de CGO comercial, além de eletrólito CGO depositado sobre substrato de YSZ comercial, apresentando uma configuração eletrólito-suporte das meia-células cátodo/eletrólito. 


\section{MATERIAIS E MÉTODOS}

Este capítulo apresenta as informações pertinentes a preparação e caracterização dos materiais estudados neste trabalho.

\subsection{Matérias-primas e reagentes utilizados}

As matérias primas de partida, assim como todos os reagentes utilizados na síntese e processamento dos materiais cerâmicos para a confecção do cátodo e cátodo, foram os seguintes:

- Nitratos de lantânio hexahidratado, estrôncio, cobalto hexahidratado e ferro nonahidratado $\left(\right.$ Aldrich $\left.^{\circledR}\right)$;

- Óxido de cério dopado com gadolínio: $\left(\mathrm{Ce}_{0,90} \mathrm{Gd}_{0,10}\right) \mathrm{O}_{1,95}$ - $\mathrm{CGO}$ (NexTech Materials, Ltd.);

- Óxido de zircônio estabilizado com 8\% em mol de óxido de ítrio: $\left(\mathrm{ZrO}_{2}\right)_{0,92}\left(\mathrm{Y}_{2} \mathrm{O}_{3}\right)_{0,08}$ - YSZ (Tosoh Corporation $\left.{ }^{\circledR}\right)$;

- Ácido cítrico e etileno glicol $\left(\operatorname{Merck}^{\circledR}\right)$;

- Álcool etílico e isopropílico (Casa Americana $\left.{ }^{\circledR}\right)$;

- Polietilenoimina e etilcelulose $\left(\right.$ Aldrich $\left.^{\circledR}\right)$.

\subsection{Composições químicas e nomenclaturas}

A fórmula química representativa da composição de cada material utilizado, assim como a nomenclatura adotada nas discussões deste trabalho referentes às etapas de síntese, misturas mecânicas ou durante e após o processamento cerâmico, são detalhadas na Tabela 4.1. 
Tabela 4.1 - Composição química e nomenclatura adotadas neste trabalho.

\begin{tabular}{|c|c|c|c|c|}
\hline Composição Química & Variação Mássica & $\begin{array}{c}\text { Nomenclatura } \\
\text { (materiais particulados) }\end{array}$ & $\begin{array}{l}\text { Temperatura de } \\
\text { Sinterização (ํ) }\end{array}$ & $\begin{array}{c}\text { Nomenclatura } \\
\text { (cerâmicas) }\end{array}$ \\
\hline \multirow{6}{*}{$\left(\mathrm{La}_{0,60} \mathrm{Sr}_{0,40}\right)\left(\mathrm{Co}_{0,20} \mathrm{Fe}_{0,80}\right) \mathrm{O}_{3-\delta}$} & \multirow{6}{*}{ - } & \multirow{6}{*}{ LSCF } & 900 & LSCF09 \\
\hline & & & 1000 & LSCF10 \\
\hline & & & 1100 & LSCF11 \\
\hline & & & 1200 & LSCF12 \\
\hline & & & 1300 & LSCF13 \\
\hline & & & 1400 & LSCF14 \\
\hline \multirow{4}{*}{-} & \multirow{4}{*}{$\begin{array}{l}75 \%\left(\mathrm{La}_{0,60} \mathrm{Sr}_{0,40}\right)\left(\mathrm{Co}_{0,20} \mathrm{Fe}_{0,80}\right) \mathrm{O}_{3-\delta} \\
25 \%\left(\mathrm{Ce}_{0,90} \mathrm{Gd}_{0,10}\right) \mathrm{O}_{1,95}\end{array}$} & \multirow{4}{*}{ LSCFCG031 } & 900 & LSCFCGO3109 \\
\hline & & & 1000 & LSCFCGO3110 \\
\hline & & & 1100 & LSCFCGO3111 \\
\hline & & & 1200 & LSCFCGO3112 \\
\hline \multirow{4}{*}{-} & \multirow{4}{*}{$\begin{array}{l}50 \%\left(\mathrm{La}_{0,60} \mathrm{Sr}_{0,40}\right)\left(\mathrm{Co}_{0,20} \mathrm{Fe}_{0,80}\right) \mathrm{O}_{3-\delta} \\
50 \%\left(\mathrm{Ce}_{0,90} \mathrm{Gd}_{0,10}\right) \mathrm{O}_{1,95}\end{array}$} & \multirow{4}{*}{ LSCFCG011 } & 900 & LSCFCG01109 \\
\hline & & & 1000 & LSCFCG01110 \\
\hline & & & 1100 & LSCFCGO1111 \\
\hline & & & 1200 & LSCFCG01112 \\
\hline \multirow{4}{*}{ - } & \multirow{4}{*}{$\begin{array}{l}25 \%\left(\mathrm{La}_{0,60} \mathrm{Sr}_{0,40}\right)\left(\mathrm{Co}_{0,20} \mathrm{Fe}_{0,80}\right) \mathrm{O}_{3-\delta} \\
75 \%\left(\mathrm{Ce}_{0,90} \mathrm{Gd}_{0,10}\right) \mathrm{O}_{1,95}\end{array}$} & \multirow{4}{*}{ LSCFCG013 } & 900 & LSCFCGO1309 \\
\hline & & & 1000 & LSCFCG01310 \\
\hline & & & 1100 & LSCFCG01311 \\
\hline & & & 1200 & LSCFCG01312 \\
\hline \multirow{4}{*}{$\left(\mathrm{Ce}_{0,90} \mathrm{Gd}_{0,10}\right) \mathrm{O}_{1,95}$} & \multirow{4}{*}{-} & \multirow{4}{*}{ CGO } & 1200 & CG012 \\
\hline & & & 1300 & CG013 \\
\hline & & & 1400 & CGO14 \\
\hline & & & 1500 & CGO15 \\
\hline \multirow{4}{*}{$\left(\mathrm{ZrO}_{2}\right)_{0,92}\left(\mathrm{Y}_{2} \mathrm{O}_{3}\right)_{0,08}$} & \multirow{4}{*}{ - } & \multirow{4}{*}{ YSZ } & 1200 & YSZ12 \\
\hline & & & 1300 & YSZ13 \\
\hline & & & 1400 & YSZ14 \\
\hline & & & 1500 & YSZ15 \\
\hline
\end{tabular}


Para as nomenclaturas das amostras em forma de materiais particulados, foram adotadas as letras LSCF representando 0 material $\left(\mathrm{La}_{0,60} \mathrm{Sr}_{0,40}\right)\left(\mathrm{Co}_{0,20} \mathrm{Fe}_{0,80}\right) \mathrm{O}_{3-\delta}$, CGO representando o $\left(\mathrm{Ce}_{0,90} \mathrm{Gd}_{0,10}\right) \mathrm{O}_{1,95}$ e YSZ representando $0\left(\mathrm{ZrO}_{2}\right)_{0,92}\left(\mathrm{Y}_{2} \mathrm{O}_{3}\right)_{0,08}$. Para a nomenclatura dessas amostras cerâmicas em forma de pastilhas, adotou-se as letras mencionadas, seguidas dos dois primeiros algarismos referentes a temperatura de sinterização realizada (por exemplo: o LSCF12 representa o LSCF sinterizado a $1200^{\circ} \mathrm{C}$ ).

Para as nomenclaturas dos compósitos em forma de materiais particulados, foram adotadas as letras LSCFCGO31 representando o material contendo $75 \%$ de LSCF e 25\% de CGO (em massa), LSCFCGO11 representando o material contendo $50 \%$ em massa de cada e LSCFCGO13 representando o material contendo 25\% de LSCF e $75 \%$ de CGO (em massa). Quando se tratar dos três compósitos, será utilizada somente a sigla LSCFCGO. Para a nomenclatura dessas amostras cerâmicas em forma de pastilhas, adotou-se o mesmo procedimento anterior, sendo os dois números finais das siglas representando os dois primeiros números da temperatura de sinterização utilizada no processamento do material.

\subsection{Procedimento experimental}

\subsubsection{Preparação dos eletrólitos (substratos) de CGO ou YSZ}

Para a preparação do eletrólito sólido (substrato), foram utilizados particulados de óxido de cério dopado com gadolínio: $\left(\mathrm{Ce}_{0,90} \mathrm{Gd}_{0,10}\right) \mathrm{O}_{1,95}$ - CGO (NexTech Materials, Ltd.) ou óxido de zircônio estabilizado com $8 \% \mathrm{em}$ mol de óxido de ítrio: $\left(\mathrm{ZrO}_{2}\right)_{0,92}\left(\mathrm{Y}_{2} \mathrm{O}_{3}\right)_{0,08}$ - YSZ (Tosoh Corporation $\left.{ }^{\circledR}\right)$. Os particulados foram conformados em pastilhas cilíndricas com $15 \mathrm{~mm}$ de diâmetro e 0,8 mm de espessura, por prensa hidráulica (30 Mpa) e prensa isostática (250 Mpa).

As pastilhas foram submetidas ao tratamento térmico sob uma taxa de aquecimento de $10^{\circ} \mathrm{C} / \mathrm{min}$ até $800^{\circ} \mathrm{C}$ e $5^{\circ} \mathrm{C} / \mathrm{min}$ até a temperatura de sinterização (1200, 1300, 1400 ou $1500^{\circ} \mathrm{C}$ por 1 ou 2 horas) em forno elétrico tipo caixa de marca LINDBERG, modelo BLUE $M$, obtendo-se pastilhas densas e mecanicamente resistentes, com dimensões de aproximadamente $14 \mathrm{~mm}$ de diâmetro e 0,6 $\mathrm{mm}$ de espessura. 
As condições de sinterização foram adotadas de acordo com os resultados da dilatometria e de trabalhos publicados ${ }^{(102 ; 103 ; 104)}$.

Após a sinterização, determinaram-se as densidades aparentes (densidade hidrostática) pelo princípio de Arquimedes, utilizando como instrumento de medida, uma balança hidrostática marca METTLER TOLEDO, modelo AG204 com precisão de $10^{-4} \mathrm{~g}$.

No preparo da superfície para receber a deposição das três camadas do cátodo compósito (LSCFCGO) seguida da deposição do cátodo (LSCF), as faces das pastilhas cilíndricas de CGO ou YSZ sinterizadas foram lixadas, utilizando lixa 320 de carbeto de silício e posterior lavagem com álcool etílico em ultrassom e secagem em estufa. Na Figura 4.1 podem ser verificadas as micrografias das superfícies de CGO sinterizada a $1400^{\circ} \mathrm{C}$ por 1 hora ou $\mathrm{YSZ}$ sinterizada a $1500^{\circ} \mathrm{C}$ por 1 hora, antes e depois de lixadas.

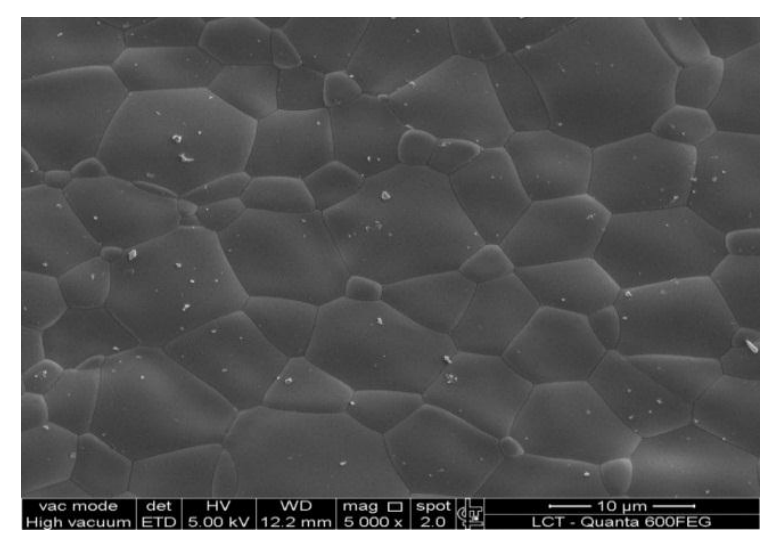

CGO sinterizada

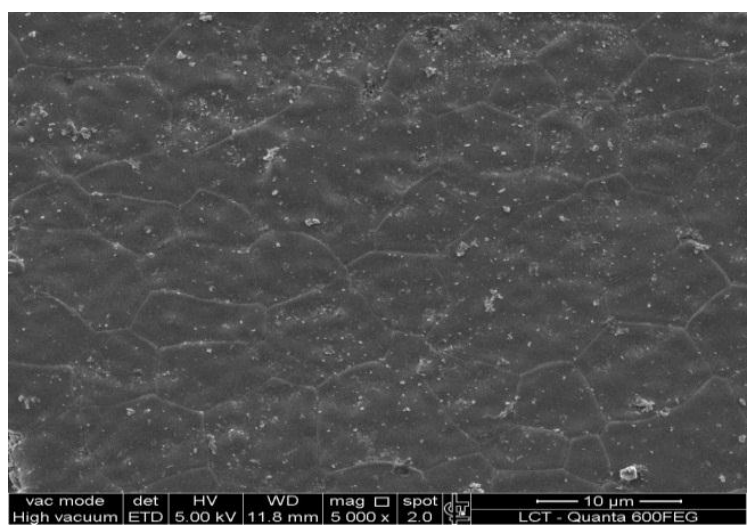

YSZ sinterizada

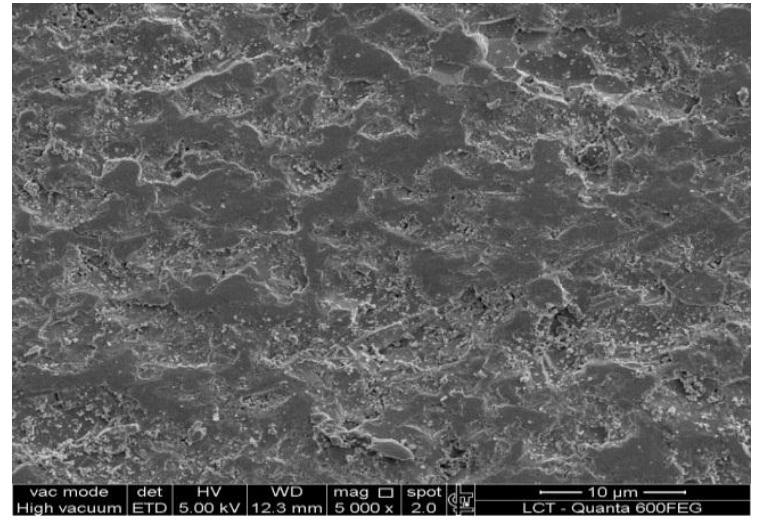

CGO sinterizada e lixada

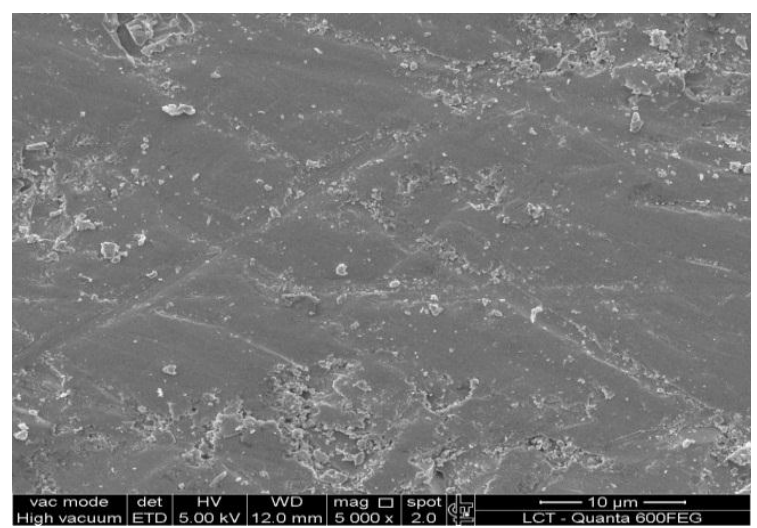

YSZ sinterizada e lixada

Figura 4.1 - Superfícies sinterizadas a 1500ํㅡ por 1 h antes e após lixamento. 
Antes desta etapa, as amostras de CGO e YSZ foram atacadas termicamente a 1350 e $1450^{\circ} \mathrm{C}$ por 30 minutos, respectivamente. O objetivo foi revelar superfícies contendo que foram alteradas após lixamento.

Este tratamento superficial no substrato produz uma superfície com a presença de ranhuras, auxiliando a aderência das camadas micrométricas na superfície dos substratos e na etapa de sinterização destas camadas.

\subsubsection{Preparação do cátodo LSCF e cátodos compósitos LSCFCGO}

Os particulados de LSCF foram sintetizados pela técnica dos citratos, que consiste na formação de quelatos em uma rede polimérica ${ }^{(37)}$.

Os nitratos de lantânio, estrôncio, cobalto e ferro, nas proporções requeridas, foram dissolvidos individualmente em água destilada. Estas soluções são misturadas e mantidas em agitação e aquecimento a $60^{\circ} \mathrm{C}$. Uma segunda solução contendo $\mathrm{HOC}_{3} \mathrm{H}_{4}(\mathrm{COOH})_{3}$ (ácido cítrico) e $\mathrm{HOCH}_{2} \mathrm{CH}_{2} \mathrm{OH}$ (etilenoglicol), na proporção 60:40, em massa, foi adicionada à solução dos nitratos, homogeneizada por agitação e aquecida entre 80 e $110^{\circ} \mathrm{C}$. O nitrato $(\mathrm{NO})$ foi liberado quando ocorreu a poliesterificação, formando uma resina de coloração marrom escuro, como verificada na Figura 4.2.
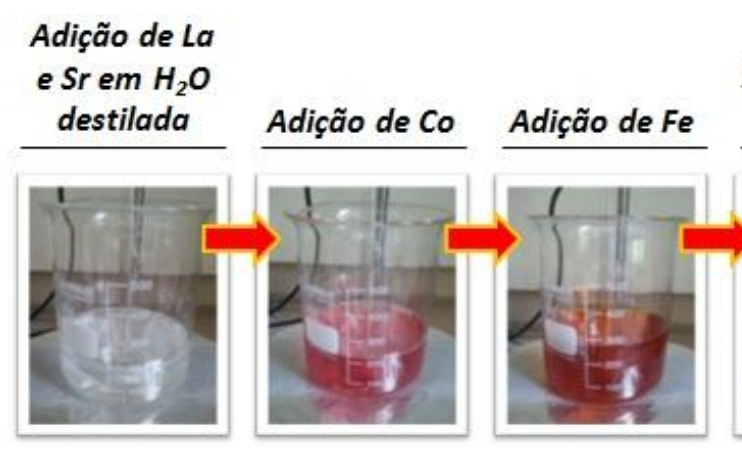

\section{Adição de} Ácido cítrico e etilenoglicol
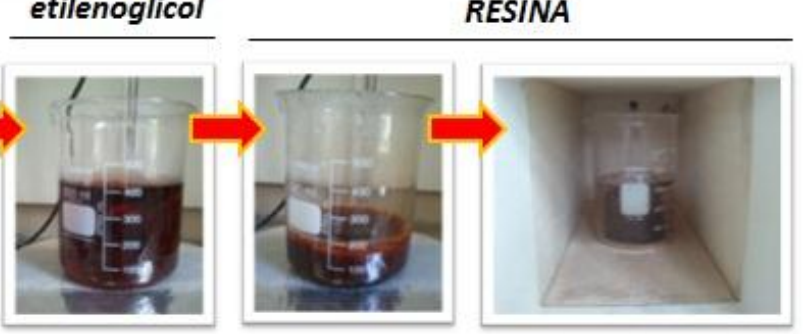

Figura 4.2 - Sequência ilustrativa da síntese de LSCF pela técnica dos citratos.

A etapa seguinte envolveu a evaporação do residual e tratamento térmico do material resinoso à temperatura de $300^{\circ} \mathrm{C}$ por 4 horas em forno mufla. Posteriormente, o material foi desaglomerado em um almofariz de ágata e calcinado em diferentes temperaturas $\left(700,800,9001000\right.$ e $1100^{\circ} \mathrm{C}$ ao ar por 4 horas) para a eliminação do carbono residual. 
A Figura 4.3 ilustra os produtos obtidos após as etapas de tratamento térmico da resina, desaglomeração, homogeneização e calcinação do material particulado para a formação do LSCF.

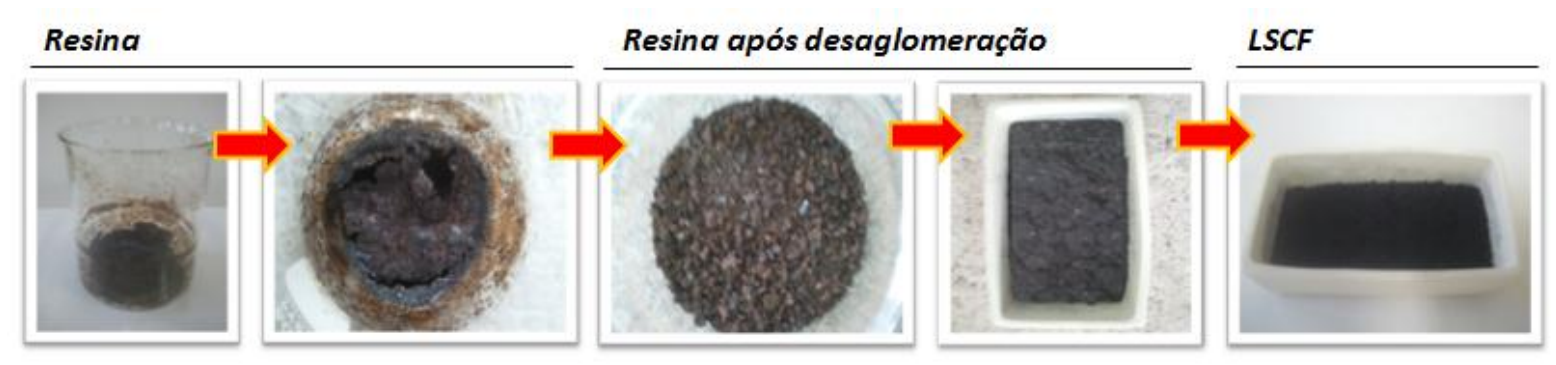

Figura 4.3 - Sequência ilustrativa para a formação dos particulados do LSCF.

Os particulados do cátodo compósito, cuja nomenclatura utilizada neste trabalho foi LSCFCGO, foram preparados pelo processo mecânico de mistura de sólidos ${ }^{(8 ; 105)}$. A mistura ocorreu em moinho atritor por 3 horas em meio orgânico (álcool isopropílico) na proporção constituída com $75 \%$ de LSCF para $25 \%$ de CGO (em massa) e denominado de LSCFCGO31 e posterior secagem em estufa a $70^{\circ} \mathrm{C}$, com homogeneização constante dos particulados durante todo processo. Em seguida, foram preparadas amostras com mais duas variações, em massa, destes materiais: $25 \%$ de LSCF com 75\% de CGO (LSCFCGO13) e 50\% de cada (LSCFCGO11). Todas as amostras foram peneiradas em peneira 200 Mesh Tyler.

Os particulados de LSCFCGO obtidos pela técnica de mistura de sólidos são revelados na Figura 4.4, onde apresentam partículas finas e de cor acinzentada escura, devido às colorações de LSCF (preto) e CGO (bege).
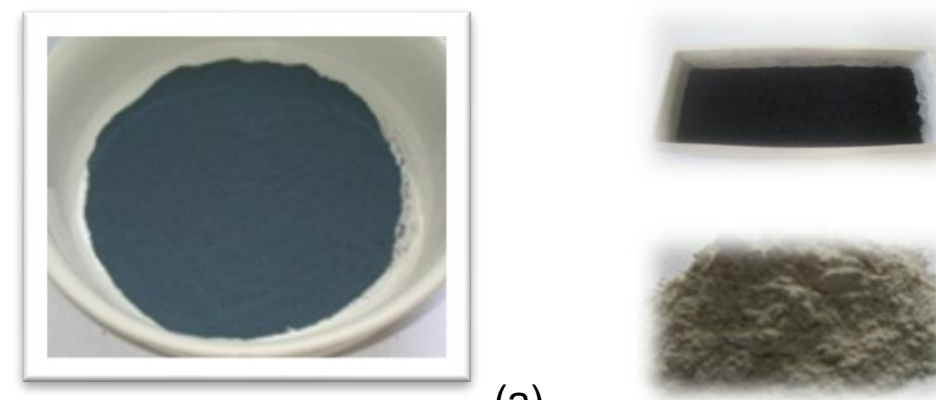

(b)

(a)

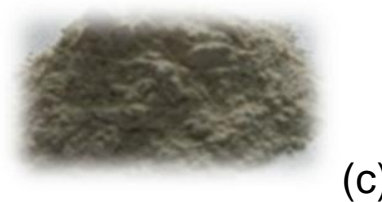

(c)

Figura 4.4 - Particulados do LSCFCGO11 (a), LSCF (b) e CGO (c). 
A Figura 4.5 apresenta o fluxograma da metodologia seguida para a síntese dos particulados de LSCF pela técnica dos citratos.

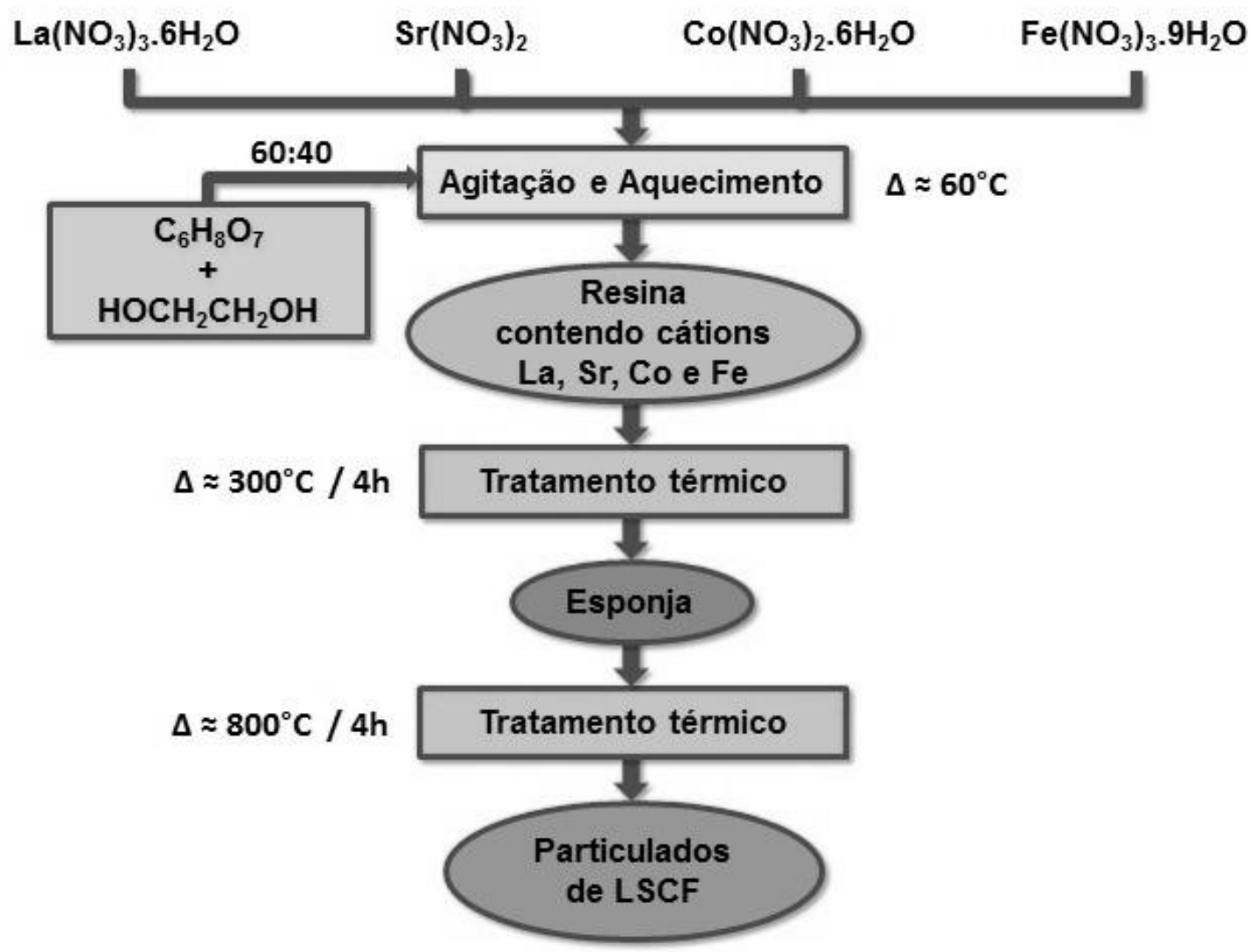

Figura 4.5 - Fluxograma da síntese de LSCF pela técnica dos citratos.

Após a etapa de síntese, os particulados de LSCF foram calcinados a $800^{\circ} \mathrm{C}$ (temperatura que resultou nos melhores resultados preliminares) durante 4 horas. O objetivo da calcinação a esta temperatura e durante este tempo foi sintetizar o material de interesse, além de auxiliar na diminuição do teor de carbono residual ${ }^{(23 ; 62 ; 64)}$. Um forno elétrico do tipo caixa e de marca LINDBERG, modelo BLUE M foi utilizado para o processo de calcinação dos particulados.

A mistura dos particulados de LSCFCGO foi realizada em moinho do tipo atritor de marca $V A R I R E D$, modelo $M 30 B F$ por 3 horas com a presença de álcool isopropílico. Esse processo foi adotado com a finalidade de alcançar maior homogeneização dos materiais misturados, ao mesmo tempo que reduziu o tamanho médio de partícula, tendo sido mais eficiente se comparado ao moinho de bolas ou mesmo a mistura manual em almofariz. 
É importante relatar que foram confeccionados acessórios exclusivos (copo, haste e haletas) para a moagem destes materiais, evitando assim, a contaminação com outros materiais processados no mesmo moinho. $O$ copo e a haste foram confeccionados em teflon e as haletas em nylon. A contaminação ocasionada pelo desgaste dos acessórios durante as operações do moinho não foram levadas em consideração, pois os materiais poliméricos são eliminados das amostras no processo de sinterização.

Entretanto, um maior cuidado foi tomado em relação aos corpos de moagem (esferas de moagem) utilizados, pois os mesmos foram feitos de zircônia. Neste caso, para evitar ao máximo qualquer tipo de contaminação, as esferas foram lavadas com acetona no ultrassom marca UNIQUE, modelo USC2850, antes de cada moagem.

A Figura 4.6 apresenta o fluxograma referente a preparação dos compósitos LSCFCGO por mistura mecânica de sólidos (mistura de óxidos).

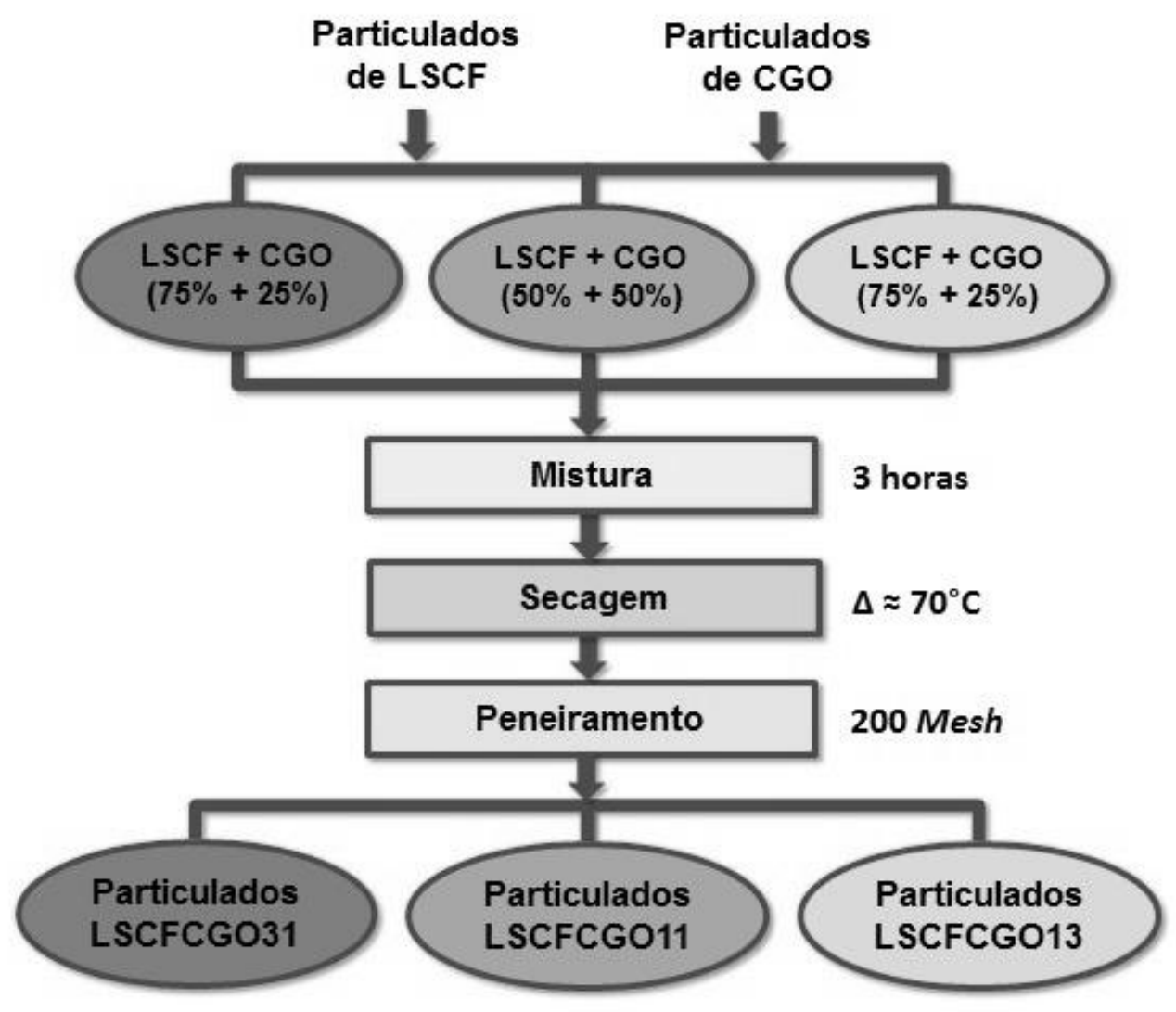

Figura 4.6 - Fluxograma da fabricação de LSCFCGO por mistura de sólidos. 


\subsubsection{Preparação das suspensões LSCF, LSCFCGO e CGO}

As suspensões para deposição nos substratos de CGO ou YSZ sinterizados e lixados foram preparadas após peneiramento dos particulados e mistura com um solvente, que neste caso foi álcool etílico. A Tabela 4.2 contém as informações pertinentes ao preparo das suspensões e sobre qual substrato cada uma foi depositada.

Tabela 4.2 - Informações das suspensões utilizadas para as deposições.

\begin{tabular}{ccc}
\hline Suspensão & $\begin{array}{c}\text { Porcentagem de } \\
\text { Particulados }\end{array}$ & $\begin{array}{c}\text { Substrato a } \\
\text { ser depositada }\end{array}$ \\
\hline LSCF & 100\% de LSCF & no filme de LSCFCGO \\
LSCFCG031 & $\begin{array}{c}\text { 75\% de LSCF } \\
\text { e } 25 \% \text { de CGO }\end{array}$ & no filme de LSCFCGO11 \\
LSCFCG011 & $\begin{array}{c}50 \% \text { de LSCF } \\
\text { e 50\% de CGO }\end{array}$ & no filme de LSCFCGO13 \\
LSCFCG013 & $\begin{array}{c}\text { e 75\% de LSCF } \\
\text { L de CGO }\end{array}$ & na pastilha ou filme de CGO \\
CGO & $100 \%$ de CGO & na pastilha de YSZ \\
\hline
\end{tabular}

Para o preparo das suspensões, adotou-se o álcool etílico como solvente, devido à rápida secagem durante as aplicações das muitas camadas para formação de filmes com espessura de interesse e principalmente em função de seu custo inferior quando comparado ao álcool isopropílico.

Os estudos iniciais de preparação de cada suspensão e das deposições das camadas resultaram em particulados de LSCF com ótima dispersão quando suspensas em álcool etílico por um período de tempo mais do que suficiente para deposição por wet poder spraying, não necessitando de um dispersante adicional na solução. Entretanto, para a confirmação da necessidade ou não de utilização de dispersante para os particulados de LSCF, LSCFCGO e CGO, foram realizados testes experimentais com polietilenoimina (PEI) como dispersante, que manteve o material particulado em suspensão e garantiu uma deposição homogênea por toda a superfície. 
A utilização de um ligante (etilcelulose) é geralmente adotado para auxiliar na aderência das camadas na superfície do substrato, dificultando a formação de trincas durante os processos de secagem e sinterização. A concentração de etilcelulose (EC) foi estabelecida com base nos dados da literatura técnica $^{(37 ; 101)}$, pois verificou-se que a concentração de $10 \%$ em massa de EC foi suficiente para evitar trincas durante a secagem e sinterização. Com tudo, foram avaliadas também suspensões sem EC e com $20 \%$ em massa.

A determinação da quantidade adequada de particulados (quantidade de sólidos) foi definida com o preparo de suspensões variando a concentração de LSCF a 5, 10 e 20\% em massa de particulados, além das quantidades de PEI e etilcelulose definidas de acordo com resultados experimentais preliminares.

Para a preparação das suspensões, os valores (em porcentagem) da concentração de sólidos foram determinados em relação ao solvente álcool etílico e a concentração de PEI e etilcelulose em relação à concentração de sólidos.

Resumidamente, os particulados foram adicionados ao solvente, para em seguida, o dispersante e o ligante serem adicionados. A homogeneização da dispersão foi realizada inicialmente em um ultrassom com agitação constante por meio de uma baqueta de vidro. Para a obtenção efetiva de uma suspensão homogênea, foi utilizado um homogeneizador (IKA) e agitação vigorosa por 30 segundos a velocidade de 7000 rpm, antes da utilização no aerógrafo.

\subsubsection{Conformação por wet powder spraying}

Para a conformação de suspensões orgânicas por wet powder spraying, foi utilizado um aerógrafo (Figura 4.7) manual de dupla ação (Harder \& Steenbeck Airbrush, modelo Evolution Silverline), cuja pulverização é realizada com alimentação da suspensão por ação da gravidade e com uso de compressor de ar (Schulz, modelo Twister). As suspensões foram pulverizadas com um bocal contendo abertura de $2 \mathrm{~mm}$ de diâmetro e pressão de ar comprimido de $100 \mathrm{MPa}$.

Durante a aplicação da suspensão sobre o substrato, o aerógrafo foi posicionado verticalmente com o bocal voltado para baixo e com uma distância até o substrato de aproximadamente $200 \mathrm{~mm}$, visto que é importante a obtenção de camadas com espessura desejada, com perda mínima de material para fora do substrato e boa distribuição da névoa (suspensão pulverizada). 

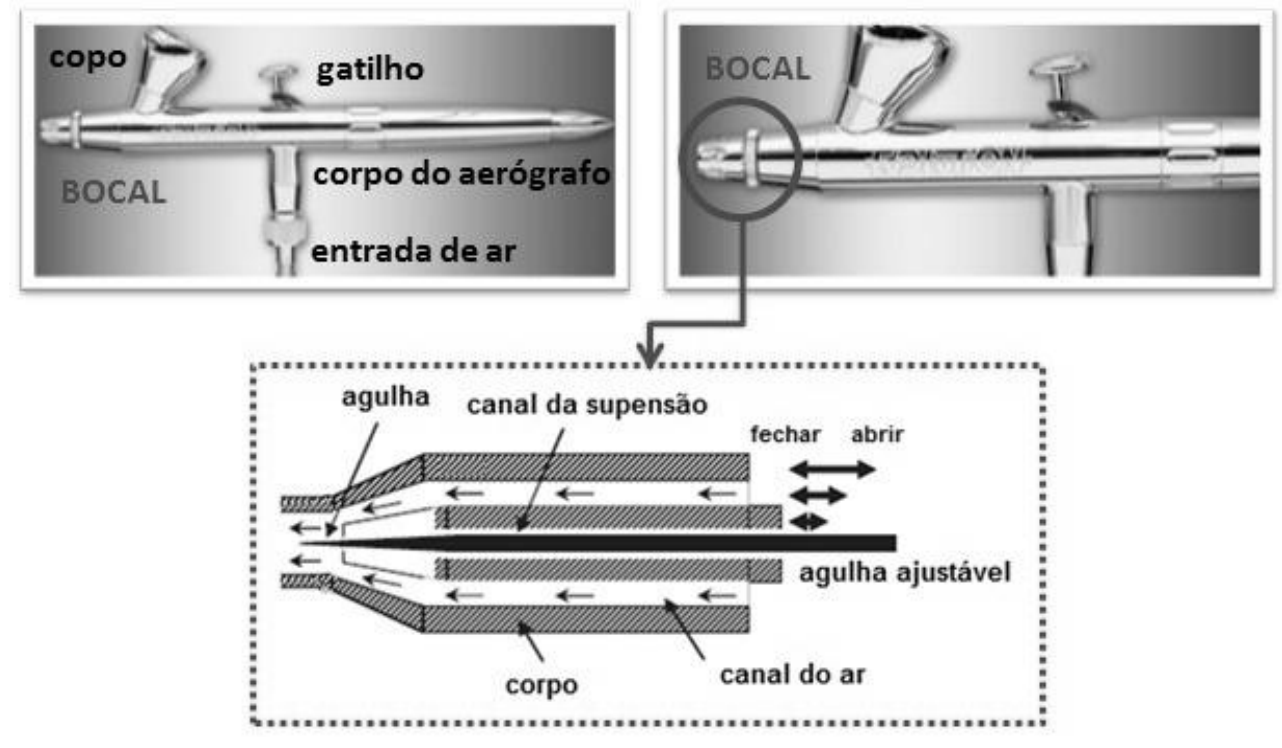

Figura 4.7 - Ilustração do aerógrafo e diagrama da seção transversal ${ }^{(37)}$.

Para a formação da camada do cátodo, foram estabelecidas deposições de 4 camadas para cada compósito e 16 para o LSCF. As camadas foram depositadas em quatro direções diferentes em relação ao plano de deposição ( $\mathrm{X}, \mathrm{Y}, \mathrm{W}$ e Z) com etapas intermediárias de secagem, com o objetivo de se obter uma espessura homogênea na faixa de micrômetros. A Figura $4.8^{\left({ }^{(37)}\right.}$ ilustra a distância entre o bocal do aerógrafo e o substrato, além das direções para as deposições de cada uma das camadas.

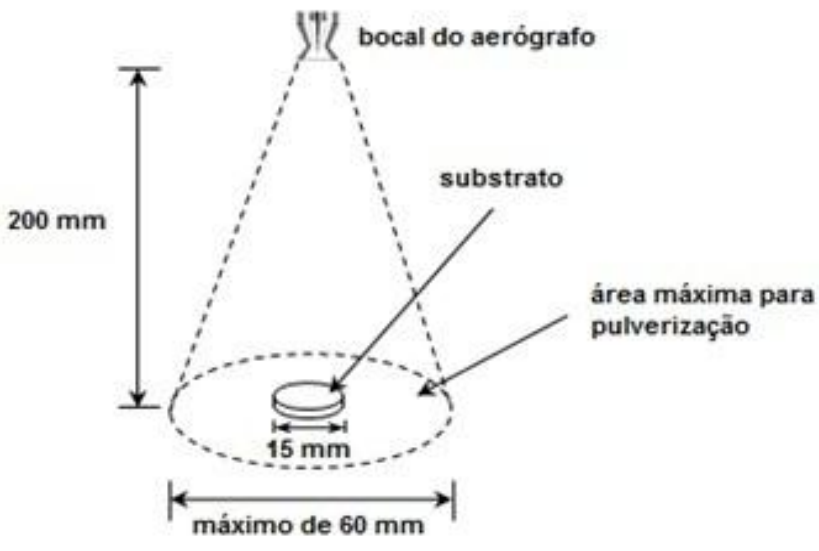

VISTA SUPERIOR

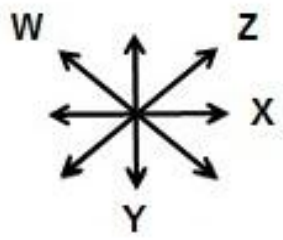

4 DIREÇOES:

$X, Y, W$ e Z

Fonte: Adaptado de Chiba, R., 2010.

Figura 4.8 - llustração da distância entre o bocal e o substrato com as direções estabelecidas para a formação de cada camada. 
Após a otimização das deposições, três tipos de corpos de prova foram preparados (Figura 4.9), sendo dois de LSCF sobre o substrato CGO com e sem camada intermediária de cátodo compósito LSCFCGO; a outra de YSZ, com camada de CGO, cátodo compósito LSCFCGO e cátodo LSCF. As camadas formadas com espessuras micrométricas foram submetidas à secagem e à sinterização com taxa de aquecimento de $3^{\circ} \mathrm{C} / \mathrm{min}$ até $500^{\circ} \mathrm{C}$ e de $5^{\circ} \mathrm{C} / \mathrm{min}$ até a temperatura de sinterização $\left(1400^{\circ} \mathrm{C}\right.$ para $\mathrm{CGO}, 1100^{\circ} \mathrm{C}$ para os compósitos LSCFCGO e para o LSCF) por 1 hora.

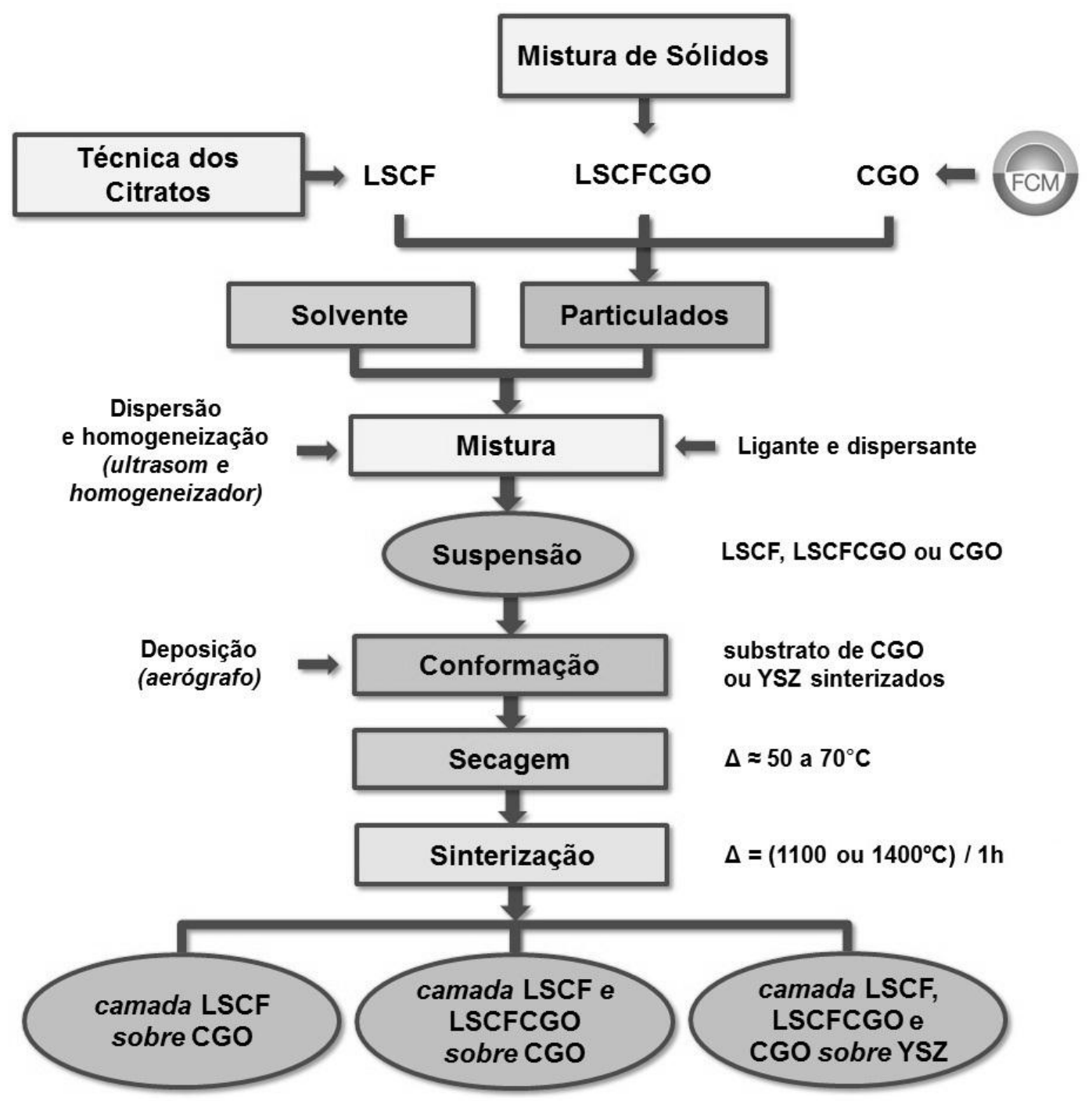

Figura 4.9 - Etapas envolvidas no processamento cerâmico. 
4.3.5. Preparação das células unitárias.

As células unitárias confeccionadas para a caracterização eletroquímica pela técnica de espectroscopia de impedância eletroquímica tem área geométrica de aproximadamente $0,30 \mathrm{~cm}^{2}$ de cátodo e de ânodo, tendo como substratos os eletrólitos de CGO ou YSZ que foram retificados para a redução da espessura $(0,40 \mathrm{~mm})$ e tratados termicamente para alívio de tensões.

O procedimento para a deposição dos cátodo encontra-se no subcapítulo 4.3.4. A deposição do ânodo de platina (eletrodo de referência) foi realizadas manualmente. Para a deposição do ânodo foram utilizados pasta e fios de platina. As células unitárias contendo o ânodo de referência (de platina) são ilustradas na Figura 4.10.
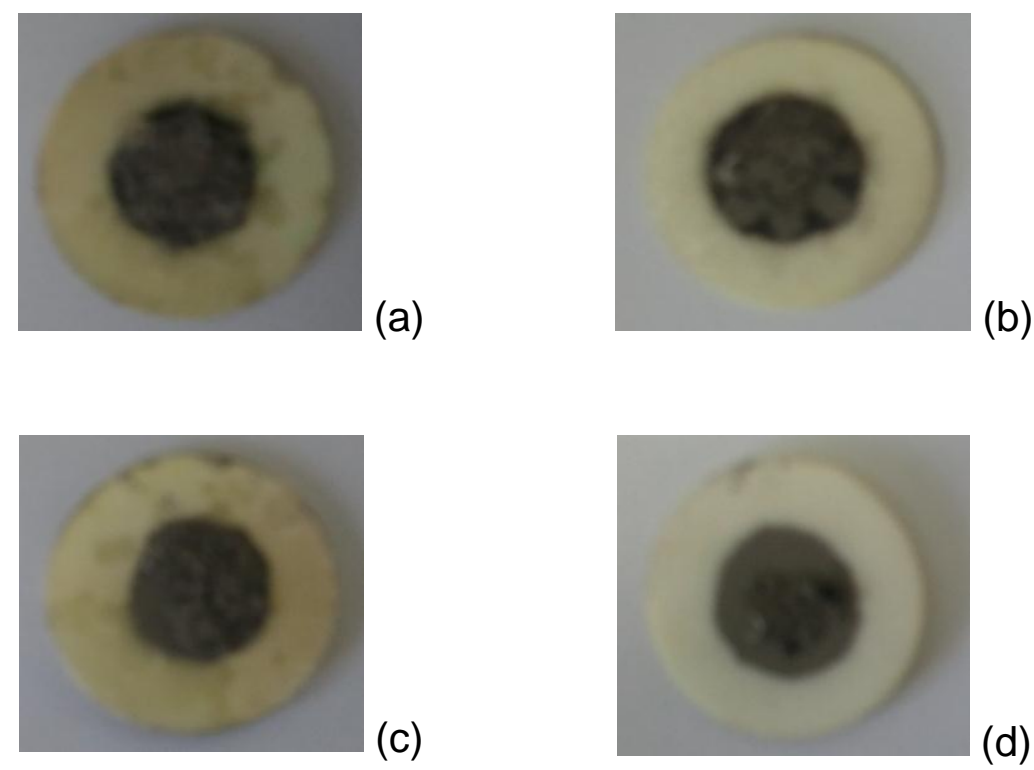

Figura 4.10 - Célula unitária no lado do cátodo sobre eletrólito de CGO (a) e YSZ (b) e ânodo (platina) sobre eletrólito de CGO (c) e YSZ (d).

\subsection{Técnicas de caracterização}

A caracterização dos materiais particulados ou cerâmicas, das suspensões e das meia-células foram realizadas por diversas técnicas de análise, que são apresentadas a seguir, com as condições utilizadas para cada técnica. 
Os materiais particulados foram caracterizados empregando-se as seguintes técnicas: análises termogravimétrica (ATG) e térmica diferencial (ATD), cromatografia de absorção gasosa ou B.E.T, fluorescência de raios $\mathrm{X}$ por energia dispersiva (FRX-EDS), análise granulométrica por espalhamento de feixes laser utilizando o software ZetaPlus Particle Sizing, picnometria por gás hélio, dilatometria, difratometria de raios $X(D R X)$ com refinamento pelo método de Rietveld e microscopia eletrônica de varredura (MEV).

As cerâmicas foram caracterizadas por determinação de densidade aparente, porosidade, DRX e microscopia eletrônica de varredura com espectroscopia com energia dispersiva (MEV-EDS).

As suspensões foram caracterizadas por medida de potencial zeta (mobilidade eletroforética), reometria e as camadas "a verde" por ATG e DRX.

As células foram caracterizadas por difratometria de raios $X$, microscopia eletrônica de varredura com micro análise por energia dispersiva (MEV-EDS) e espectroscopia de impedância eletroquímica.

\section{Análise térmica diferencial (ATD) e análise térmica gravimétrica (ATG)}

As análises térmicas diferenciais (ATD) são utilizadas para acompanhar as transformações químicas e físicas que ocorrem na amostra em função da temperatura. Por esta técnica, é possível verificar a temperatura em que ocorrem fenômenos como: transformações de estrutura, reações que envolvem liberação ou absorção de energia, transformações de fase, mudanças de estado, desprendimento de gases e aparecimento de fases líquidas ${ }^{(105 ; 106)}$.

A técnica consiste em aquecer um material juntamente com um padrão, a uma taxa constante, registrando-se pequenas variações de energia medidas por termopares, entre este e a amostra analisada, em função do aumento gradual da temperatura ${ }^{(105 ; 106)}$. Na ATD é observada uma diferença de temperatura entre a amostra e o material de referência, ocasionadas por reações endotérmicas e exotérmicas consequentes da variação de temperatura ${ }^{(106 ; 107)}$.

$\mathrm{Na}$ análise térmica gravimétrica (ATG), também conhecida como termogravimétrica, é verificada a variação de perda ou ganho de massa de uma substância em função da temperatura, decorrentes de processos de oxidação, redução, entre outros ${ }^{(106 ; 107)}$. 
As análises podem ser realizadas simultaneamente no mesmo equipamento, com ou sem controle de atmosfera. O gráfico obtido registra as variações de energia (para a ATD) e de massa (para a ATG) com a temperatura. As transformações endotérmicas ou exotérmicas são registradas como deflexões em sentidos opostos na curva, sendo, por exemplo; caracterizadas como endotérmicas, as reações de decomposição, evaporação, liquefação, fusão, dissociação gasosa, entre outras; e exotérmicas, as oxidações, cristalizações, algumas transformações cristalinas, entre outras ${ }^{(106 ; 107)}$.

As análises de ATD e ATG da resina base para a síntese de LSCF foram realizadas em um equipamento marca Setaram Instrumentation, modelo Labsys S60/51935. O material de referência foi alumina, a velocidade de aquecimento foi de $10^{\circ} \mathrm{C} / \mathrm{min}$, a temperatura de $1200^{\circ} \mathrm{C}$ sob fluxo de ar sintético.

\section{Absorção gasosa}

$\mathrm{Na}$ análise por absorção gasosa, o teor de carbono residual presente nos materiais é determinado utilizando-se o princípio analítico de absorção da radiação infravermelha. Este princípio ocorre em duas etapas, sendo a primeira envolvendo a extração dos gases do material sob atmosfera de oxigênio, na forma de $\mathrm{CO}$ e $\mathrm{CO}_{2}$ em forno de radiofrequência, e a segunda envolvendo a identificação analítica dos gases em uma célula de infravermelho (detector) ${ }^{(106)}$.

Normalmente, nos materiais analisados são utilizados aceleradores para auxiliar a combustão no forno de indução, diminuindo o ponto de fusão. $O$ teor de carbono é analisado na faixa de ppm, tendo um limite mínimo de detecção de 0,50 ppm e desvio padrão de aproximadamente $10 \%{ }^{(106)}$.

Os teores de carbono residuais dos particulados de LSCF calcinados a $700,800,900,1000$ e $1100^{\circ} \mathrm{C}$ foram obtidos em um cromatógrafo marca LECO, modelo CS400. O cadinho utilizado para queima do material foi alumina e o acelerador fundente foi uma mistura de tungstênio/estanho.

\section{Espectrometria de fluorescência de raios $\mathrm{X}$ por energia dispersiva}

O espectrômetro de fluorescência de raios $X$ (FRX) utiliza feixes de raios $X$ para excitar o material a ser analisado. Os elementos químicos presentes 
na constituição do material, após a incidência do feixe, emitem seus raios $X$ característicos, que são detectados pelo equipamento e podendo ser mensurados qualitativamente e quantitativamente.

A fluorescência de raios $X$ por energia dispersiva, conhecida como FRX-EDS, emite raios $X$, que são detectados através de um detector (semicondutor), o qual permite análises simultâneas multi-elementar, possibilitando uma análise extremamente rápida na faixa de ppm. As análises ao ar são possíveis, devido à pequena distância entre o material e o detector, e desta forma, a grande maioria dos materiais pode ser medida sem a necessidade da existência de vácuo ${ }^{(105 ; 107)}$.

As composições químicas dos particulados foram obtidas em um espectrômetro marca Shimadzu, modelo EDX 900HS. As amostras foram condicionadas em porta amostra de teflon e polipropileno em vácuo.

\section{Análise granulométrica por espalhamento de feixes de laser}

A análise granulométrica por espalhamento de laser permite determinar a distribuição dos diâmetros médios de partículas utilizando os fenômenos de difração e difusão de um feixe laser ao atravessar o meio onde se encontram as partículas em suspensão ${ }^{(108)}$. O laser apresenta uma potência de $15 \mathrm{~mW}$, possibilitando tempo de medidas tipicamente de 1 a 2 minutos ${ }^{(109)}$.

A distribuição dos diâmetros médios das partículas dos materiais estudados foram obtidos em um analisador de potencial zeta (conhecido como zetâmetro) de marca Brookhaven, modelo ZetaPALS (Phase Analysis Light Scattering). As suspensões orgânicas diluídas na faixa de 0,0001 a 1\% em volume a temperatura ambiente foram dispersas em ultrassom e analisadas utilizando o software ZetaPlus Particle Sizing.

\section{Área de superfície específica}

A medida da área de superfície ou área superficial específica de um sólido, teoria proposta por BRUNAUER, EMMETT e TELLER ${ }^{(110)}$, conhecida como B.E.T., descreve a adsorção física dos gases em superfícies sólidas. 
A ação de forças ativas na condensação das moléculas de gases em uma camada são as responsáveis pela energia de ligação entre as múltiplas camadas adsorvidas. $\mathrm{O}$ aumento da adsorção física dos gases nos sólidos ocorre com a diminuição da temperatura e aumento da pressão. As amostras são aquecidas para eliminação da umidade, posteriormente resfriadas e alimentadas pelo gás a ser adsorvido a uma temperatura fixa e pressão parcial variável. Os dados das curvas de adsorção são tratados e analisados adequadamente para a determinação da área de superfície específica ${ }^{(111 ; 112)}$.

A partir do valor da área de superfície específica obtido foi possível a determinação do tamanho médio das partículas do material utilizando a equação $7^{(111 ; 113)}$ que considera a morfologia das partículas esféricas.

$$
D=\frac{6}{\rho * S}
$$

Onde:

$$
\begin{aligned}
& D=\text { diâmetro médio da partícula }(\mu \mathrm{m}) ; \\
& \rho=\text { densidade teórica do material }\left(\mathrm{g} / \mathrm{cm}^{3}\right) ; \\
& \mathrm{S}=\text { área específica da partícula }\left(\mathrm{m}^{2} / \mathrm{g}\right) .
\end{aligned}
$$

As áreas de superfície específica para os particulados foram obtidas em um equipamento marca Micromeritics, modelo ASAP 2010. As amostras de aproximadamente 1,00 grama foram aquecidas à temperatura de $300^{\circ} \mathrm{C}$ para eliminação da umidade e impurezas adsorvidas na presença de nitrogênio.

\section{Picnometria por gás hélio}

A análise por picnometria por gás hélio consiste na obtenção do volume de um sólido pela redução do fluxo de gás em uma câmara de medida, causada pela presença do sólido. O gás hélio penetra nas superfícies irregulares e nos poros, onde o volume obtido e a massa determinada, permitem o cálculo da densidade real ou massa específica desse sólido ${ }^{(113)}$. 
As densidades determinadas por picnometria por gás hélio, para os particulados foram obtidas em um picnômetro marca Micromeritics, modelo 1330.

\section{Método de determinação da densidade geométrica (verde e sinterizados)}

Após a etapa de conformação e antes a após a sinterização, as amostras em forma de pastilhas cilíndricas foram submetidas a medidas de massa, diâmetro e espessura para o cálculo da densidade geométrica a verde e da densidade geométrica dos sinterizados (equação 8) ${ }^{(82)}$ :

$$
\rho_{g}=\frac{M}{V_{C}}=\frac{M}{\left(\pi * r^{2} * h\right)}
$$

Onde:

$$
\begin{aligned}
& \rho_{\mathrm{g}}=\text { densidade geométrica }\left(\mathrm{g} / \mathrm{cm}^{3}\right) \\
& \mathrm{M}=\text { massa }(\mathrm{g}) \\
& \mathrm{Vc}=\text { volume da pastilha cilíndrica }\left(\mathrm{cm}^{3}\right) \\
& \mathrm{r}=\text { raio do cilindro }(\mathrm{cm}) \text { e } \mathrm{h}=\text { altura do cilindro }(\mathrm{cm})
\end{aligned}
$$

\section{Método de determinação da densidade aparente (princípio de Arquimedes)}

O princípio de Arquimedes afirma que um corpo imerso em um fluido sofre a ação de duas forças, peso e empuxo, sendo a intensidade do empuxo igual e contrária ao peso do fluido deslocado pelo corpo ${ }^{(82)}$.

Por este método, o material sinterizado é imerso em um líquido fervendo durante um tempo suficiente para que o mesmo penetre nas superfícies irregulares e regiões contendo espaços, como poros abertos e conectados. $O$ cálculo da densidade aparente (hidrostática) é obtida pela equação 9.

$$
\rho_{H}=\frac{M_{s}}{M_{u}-M_{i}} * \rho_{l}
$$


Onde:

$$
\begin{aligned}
& \rho_{H}=\text { densidade do material }\left(\mathrm{g} / \mathrm{cm}^{3}\right) ; \\
& M_{\mathrm{S}}=\text { massa seca }(\mathrm{g}) ; \\
& \rho_{\mathrm{L}}=\text { densidade do líquido na temperatura medida }\left(\mathrm{g} / \mathrm{cm}^{3}\right) ; \\
& M_{\mathrm{u}}=\text { massa úmida }(\mathrm{g}) ; \\
& M_{\mathrm{i}}=\text { massa imersa }(\mathrm{g}) .
\end{aligned}
$$

As densidades aparentes das cerâmicas de LSCF, LSCFCGO, CGO e YSZ foram obtidas em uma balança marca Mettler Toledo, modelo AG 204 com precisão de $10^{-4} \mathrm{~g}$. As amostras foram colocadas em água destilada em ebulição durante 3 horas; e resfriadas a temperatura ambiente. Na sequência, foram efetuadas medidas das massas úmidas e imersas em temperatura ambiente. Todas as medidas das massas secas foram realizadas após a secagem em estufa a aproximadamente $100^{\circ} \mathrm{C}$ e resfriadas em um dessecador.

\section{Método de determinação da densidade teórica e porosidade}

A densidade teórica foi obtida no banco de dados JCPDS de DRX e a porosidade de todas as amostras foi calculada através da equação 10:

$$
P=\frac{\left(\rho_{t}-\rho_{A}\right)}{\rho_{t}} * 100
$$

Onde:

$$
\begin{aligned}
& \mathrm{P}=\text { porosidade }(\%) \\
& \rho_{t}=\text { densidade teórica }\left(\mathrm{g} / \mathrm{cm}^{3}\right) \\
& \rho_{A}=\text { densidade aparente }\left(\mathrm{g} / \mathrm{cm}^{3}\right)
\end{aligned}
$$




\section{Microscopia eletrônica de varredura (MEV) e espectroscopia de energia dispersiva de raios $X$ (EDS)}

O princípio de funcionamento do microscópio eletrônico de varredura (MEV) consiste na emissão de um feixe de elétrons entre os eletrodos, provocando uma diferença de potencial $(0,50$ a $30 \mathrm{kV})$, que permite a aceleração dos elétrons e, consequentemente, aquecimento do filamento. $O$ eletrodo positivo do microscópio atrai os elétrons gerados, resultando em sua aceleração. A correção do percurso dos feixes de elétrons é realizada pelas lentes condensadoras que "varrem" a superfície da amostra contida em uma câmara com vácuo. A interação dos feixes de elétrons com a superfície do material promovem a emissão de elétrons secundários, retroespalhados, Auger, raios $\mathrm{X}$ característicos de cada elemento químico e fótons. Os elétrons secundários e os retroespalhados são os sinais mais utilizados para a formação de imagem no microscópio eletrônico de varredura ${ }^{(114-116)}$. O MEV é um equipamento capaz de produzir imagens de alta resolução, da ordem de até 300.000 vezes, permitindo a obtenção de resultados microestruturais tanto físicos como químicos.

A espectroscopia de energia dispersiva de raios $X$ (EDS) consiste na emissão de feixe de elétrons incidente sobre uma amostra, sendo que os elétrons mais externos dos átomos e os íons constituintes são excitados, mudando de níveis energéticos. Quando retornam para seu estado fundamental, liberam a energia adquirida, a qual é emitida na forma de raios $X$. Um detector instalado no interior da câmara de vácuo mede a energia associada a esse elétron ${ }^{(115 ; 116)}$.

Como os elétrons de um determinado átomo possuem energias distintas, é possível, no ponto de incidência do feixe, determinar e identificar quais os elementos químicos estão presentes. O diâmetro reduzido do feixe permite a determinação da composição em amostras de tamanhos muito reduzidos (inferiores a $5 \mu \mathrm{m}$ ), permitindo uma análise mais precisa.

A vantagem de se utilizar a energia dispersiva, além da imediata identificação dos elementos químicos presentes, é permitir o mapeamento da distribuição de elementos químicos na amostra, gerando mapas composicionais dos elementos de interesse ${ }^{(115 ; 116)}$. 
As imagens obtidas dos particulados foram realizadas em microscópio marca Philips, modelo XL 30. Para a preparação, os particulados e as meiacélulas foram colocados sobre portas amostras de alumínio.

Inicialmente, foi realizada uma dispersão do material em acetona utilizando um ultrassom. Uma pequena alíquota foi retirada da suspensão e depositada sobre o porta amostra. Após a secagem da suspensão, foi aplicado um recobrimento contendo platina por sputtering e levado ao MEV para observação do tamanho e a forma das partículas e/ou aglomerados.

Para a avaliação das superfícies e das seções transversais fraturadas, utilizou-se o microscópio eletrônico de varredura, marca FEl, modelo Quanta 600 FEG (Field Emission Gun), sendo esse equipamento munido de um detector Bruker SDD Quantax400 para microondas.

As células foram fixadas com fita adesiva e com cola de prata e levadas ao MEV/EDS para observação quanto à porosidade, espessura e identificação dos elementos químicos presentes.

O recobrimento com platina pela técnica de sputtering em plasma de argônio foi também utilizado para todas as amostras analisadas no MEV e recobrimento contendo carbono para as amostras analisadas por EDS, evitando interferência durante a identificação dos elementos químicos.

\section{Difratometria de raios X (DRX) e refinamento pelo método de Rietveld}

$\mathrm{Na}$ análise por difratometria de raios $X(D R X)$ são possíveis as identificações e as quantificações das fases cristalinas presentes na constituição do material, verificações das estruturas cristalinas, parâmetros de rede e determinação do tamanho médio de cristalito do material.

Esta técnica detecta 0 feixe de raios $X$ difratado após a incidência sobre o material de interesse. No reticulado cristalino, onde os átomos estão regularmente espaçados e a radiação incidente possui comprimento de onda da ordem destes espaços, ocorre a difração desta radiação. Os feixes difratados pelos átomos no reticulado cristalino, nos planos cristalográficos sofrem interferência construtiva quando a diferença entre os caminhos é um múltiplo inteiro de $\lambda$. Isto é representando na forma da Lei de Bragg, e que segue a equação $11^{(117)}$. 


$$
n * \lambda=2 * d * \operatorname{sen} \theta
$$

Onde: $\mathrm{n}$ (número do comprimento de onda); $\lambda$ (comprimento de onda da radiação incidente); d (distância entre dois planos adjacentes) e $\theta$ (ângulo de incidência).

Os difratogramas dos particulados foram obtidos num difratômetro marca Rigaku, modelo Multiflex e DMAX2000. Os particulados ou as cerâmicas sinterizadas foram analisadas utilizando radiação CuKa, na faixa angular de $2 \theta$ de 10 a $90^{\circ}$ ou 20 a $80^{\circ}$ e passo de varredura de $0,02^{\circ}$ por minuto.

O método de Rietveld é uma técnica de refinamento que consiste em realizar ajuste de um padrão de difração teórico da amostra a ser obtida em um processo de varredura passo a passo em um padrão experimental. O refinamento com os fatores instrumentais são levados em consederação e os parâmetros estruturais característicos como parâmetros de rede, posições atômicas, tamanho de cristalito, entre outros, são determinados ${ }^{(117 ; 118)}$.

O software utilizado para o refinamento foi o GSAS (General Structure Analysis System) e para a identificação das fases presentes e suas respectivas estruturas foram utilizados os bancos de dados ICSD-2005 (Inorganic Crystal Structure Database) e o PDF2-2003 (Powder Diffraction File).

\section{Dilatometria}

$\mathrm{Na}$ dilatometria são medidas as variações das dimensões (expansão e retração) de uma amostra em função da temperatura. $O$ aumento da amplitude vibracional entre os átomos da amostra na temperatura medida faz com que ocorram estas variações das dimensões, no qual é determinado pela força de ligação e pelo arranjo atômico do material ${ }^{(119)}$.

As análises dilatométricas foram realizadas em um dilatômetro marca

Setaram Instrumentation, modelo Labsys S60/51935. As amostras foram confeccionadas na forma de cilindros por prensagem uniaxial, com dimensões de $5 \mathrm{~mm}$ de diâmetro por aproximadamente $6 \mathrm{~mm}$ de comprimento, e analisadas com velocidade de aquecimento de $5^{\circ} \mathrm{C} / \mathrm{min}$, até a temperatura de $1400^{\circ} \mathrm{C}$, com fluxo de ar sintético e velocidade de resfriamento de $20^{\circ} \mathrm{C} / \mathrm{min}$. 


\section{Determinação do potencial zeta}

A estabilidade dos particulados de LSCF e CGO em meio aquoso foi determinada a partir das medidas de mobilidade eletroforética no intervalo de $\mathrm{pH}$ entre 2 e 12, realizadas em um analisador de espalhamento de feixes luz (ZetaPALS, Brookhaven Instruments Corporation, EUA).

\section{Reometria}

$\mathrm{Na}$ análise por reometria foi possível estudar o comportamento reológico das suspensões em reômetros rotativos, que podem operar nos modos de velocidade e tensão controlada. As medidas são analisadas em um sensor duplo cone, que abrange uma grande variação na taxa de cisalhamento $(0,006$ a $9000 \mathrm{~s}^{-1}$ ) e valores de viscosidade entre 1 a $50000 \mathrm{~m} \mathrm{~Pa}^{*}{ }^{(85)}$.

As curvas de viscosidade e de fluxo das suspensões de LSCF e de CGO foram obtidas no reômetro marca HAAKE, modelo RS600. As suspensões foram caracterizadas no modo de velocidade controlada (CR), com velocidade de cisalhamento de 0 a $1000 \mathrm{~s}^{-1}$, mantendo a uma temperatura constante de $26^{\circ} \mathrm{C}$.

\section{Espectroscopia de impedância eletroquímica}

A análise por espectroscopia de impedância eletroquímica (EIE) consiste em uma aplicação de um potencial alternado de baixa amplitude (geralmente entre 2 e $10 \mathrm{mV}$ ) entre dois polos presentes no material a ser analisado. A magnitude da corrente resultante e a variação no ângulo de fase $\Phi$ (ângulo dos vetores de impedância) são medidas em função da frequência, que pode variar de $10^{-2}$ a $10^{6} \mathrm{~Hz}$, dependendo do material ${ }^{(120)}$.

A impedância é expressa em termos de magnitude $\left(Z_{0}\right)$ e um ângulo de fase $(\Phi)$, a qual em função da frequência angular $\left(Z_{w}\right)$ pode ser representada em termos de coordenada cartesiana conforme a equação 12:

$$
Z_{W}=R_{e} Z+j l m Z
$$


Onde: $\operatorname{ReZ}\left(Z^{\prime \prime}\right)$ que representa a parte real e $\operatorname{ImZ}\left(Z^{\prime}\right)$ que representa a parte imaginária da impedância.

Na EIE, um diagrama de impedância consiste na representação da parte imaginária Z" em função da parte real Z', conhecido como Diagrama de Nyquist. Neste diagrama, o eixo y é negativo e cada ponto no gráfico é a impedância a uma dada frequência. Os valores de frequências de baixa para as mais altas vão da direita para a esquerda. Na Figura $4.11^{(37 ; 120)}$ é ilustrado um exemplo de um circuito elétrico com seu diagrama de Nyquist, de um resitor $\mathrm{R}_{1}$ em série com um capacitor $C$ em paralelo com um resistor $R_{2}$.

representação do circuito elétrico

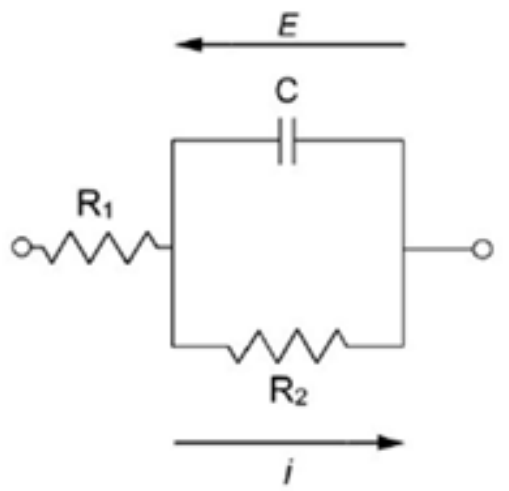

\section{Diagrama de Nyquist}

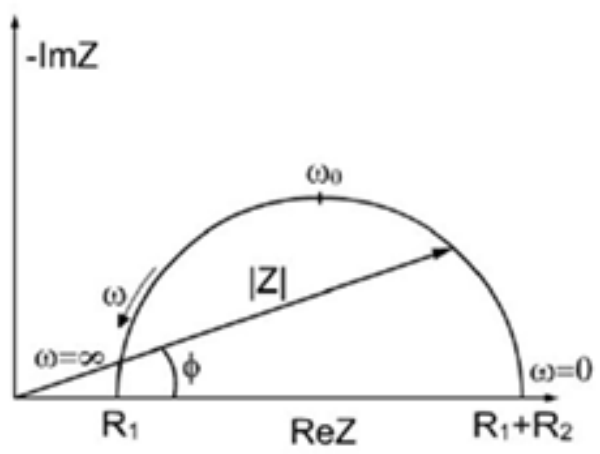

Figura 4.11 - llustração de um circuito elétrico com diagrama de Nyquist.

As medidas eletroquímicas das células unitárias foram realizadas em um sistema (Figura 4.12) construído no Laboratório de Caracterização Elétrica do $\mathrm{CCCH}$ no IPEN-CNEN/SP. Para a vedação na célula unitária nos compartimentos do cátodo e do ânodo, foi utilizada uma massa constituída de material vítreo (selante) para selar a célula unitária com o tubo de alumina. A célula unitária com o selante foi colocada entre os tubos de alumina de igual diâmetro, onde existe 0 fluxo dos gases hidrogênio e ar, além dos contatos elétricos. $O$ eletrodo de referência de platina ficou em contato com o ar, sendo todos os potenciais expressos em relação ao eletrodo de referência. 
A caracterização eletroquímica da RRO foi realizada mediante levantamento de curvas de polarização e impedância eletroquímica na temperatura entre 500 e $650^{\circ} \mathrm{C}$.

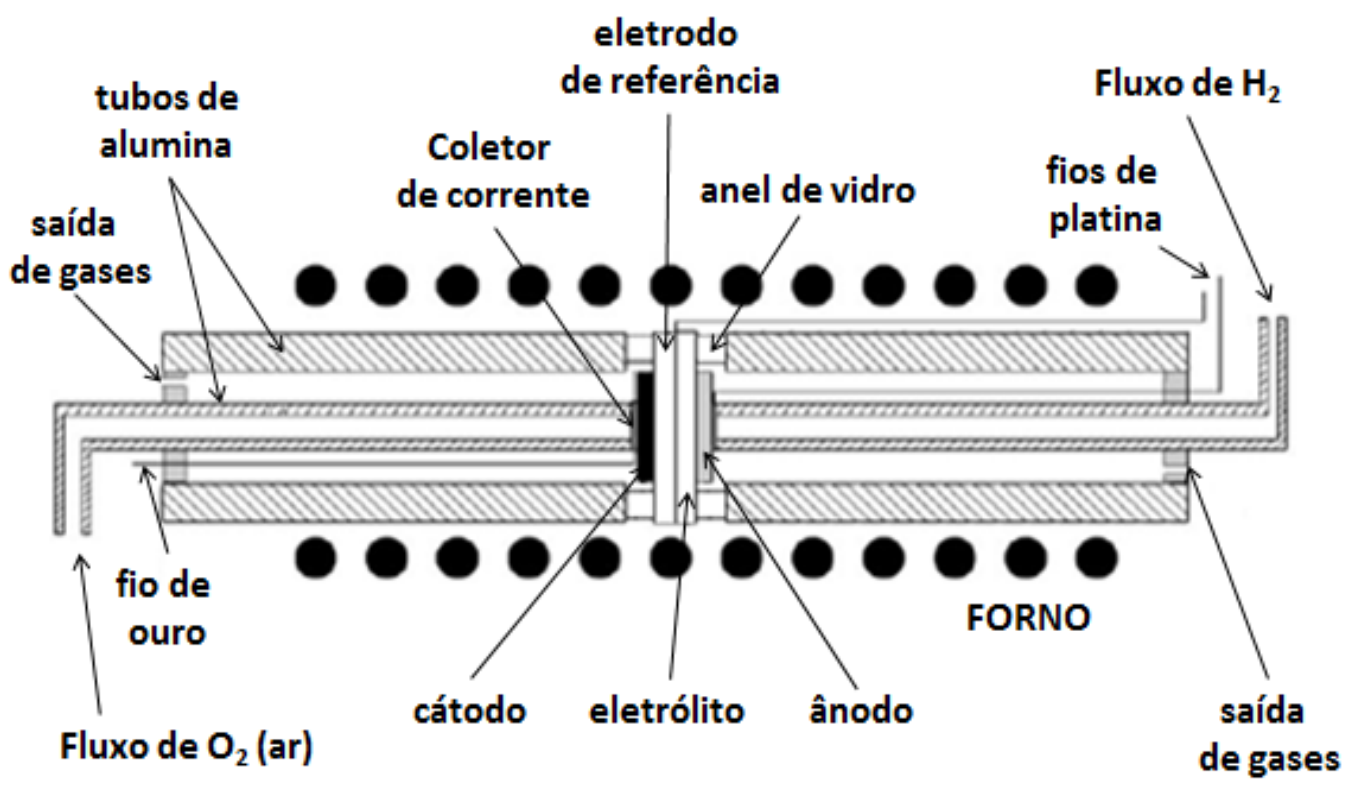

Figura 4.12 - Esquema de caracterização eletroquímica das células unitárias.

Os dados da espectroscopia de impedância foram utilizados tanto para fazer a correção de queda ôhmica dos dados de polarização, como para investigar os parâmetros que contribuem para a resistência interna da célula no lado do cátodo correspondente aos materiais LSCF e LSCFCGO. 


\section{RESULTADOS E DISCUSÃO}

Neste capítulo, dividido em quatro partes, são discutidos os resultados obtidos para o estudo proposto. A primeira parte apresenta um estudo de síntese e caracterização dos materiais particulados constituídos de LSCF, preparação e caracterização dos compósitos LSCFCGO e caracterização dos particulados comerciais de CGO e YSZ. A segunda parte apresenta as caracterizações químicas, físicas e microestruturais das cerâmicas de cada um dos materiais envolvidos no estudo. A terceira parte trata-se de resultados e discussão do estudo de processo para preparação das suspensões e deposição por aerografia. A quarta e última parte, apresenta os resultados das caracterizações físicas, microestruturais e elétricas das células unitárias.

\subsection{Caracterização dos materiais particulados}

Inicialmente, foi realizado um estudo de decomposição dos precursores para a síntese do LSCF utilizando análise termogravimétrica (ATG), e um estudo em paralelo de difração de raios $X(D R X)$ para a verificação da formação do material de interesse sem a presença de fases secundárias.

A temperatura de $300^{\circ} \mathrm{C}$ por 4 horas para a transformação da resina, contendo os precursores de nitratos, no material com aspecto esponjoso, foi definida de acordo com trabalhos anteriores do grupo ${ }^{(23)}$ e literatura técnica ${ }^{(29 ; 37)}$. Nestes estudos, concluiu-se que a liberação da água residual ocorreu à temperatura de aproximadamente $127^{\circ} \mathrm{C}$ e que a maior perda de massa ocorreu em temperaturas de até $600^{\circ} \mathrm{C}$ devido à reação de combustão entre 280 e $530^{\circ} \mathrm{C}$, relacionada à queima do excesso de polietileno glicol e de outros precursores orgânicos presentes durante a síntese.

Por ATG, analisou-se a 'esponja' (material recolhido antes da etapa de calcinação) obtida após a síntese pela técnica dos citratos. As curvas termogravimétricas obtidas são apresentadas na Figura 5.1 e permitem diferenciar cinco etapas de decomposição e transformações dos compostos até a temperaturas de $1000^{\circ} \mathrm{C}$ e atmosfera de ar sintético: 
- Entre a temperatura ambiente e aproximadamente $275^{\circ} \mathrm{C}$, ocorre uma relativa perda de massa (expressa em miligramas), que corresponde à perda da água de hidratação e inicio da decomposição dos nitratos;

- Entre 275 e $400^{\circ} \mathrm{C}$ ocorre à decomposição dos nitratos formando $\mathrm{NO}_{2}$ e início da liberação de gases $\mathrm{CO}$ e $\mathrm{CO}_{2}$;

- Entre 400 e $600^{\circ} \mathrm{C}$ segue-se a decomposição dos nitratos formando $\mathrm{NO}_{2}, \mathrm{NO}_{x}$ e nitratos intermediários, ocorrendo maior liberação de $\mathrm{CO}$ e $\mathrm{CO}_{2}$ provenientes da decomposição do ácido cítrico e etilenoglicol;

- Entre 600 e $750^{\circ} \mathrm{C}$ inicia-se a formação do produto final estável de LSCF. Nesta etapa ainda ocorre liberação de $\mathrm{CO}$ e $\mathrm{CO}_{2}$ residuais;

- A $750^{\circ} \mathrm{C}$ ocorre à formação do material de interesse e, a partir de $800^{\circ} \mathrm{C}$, o produto formado mostra-se bastante estável.

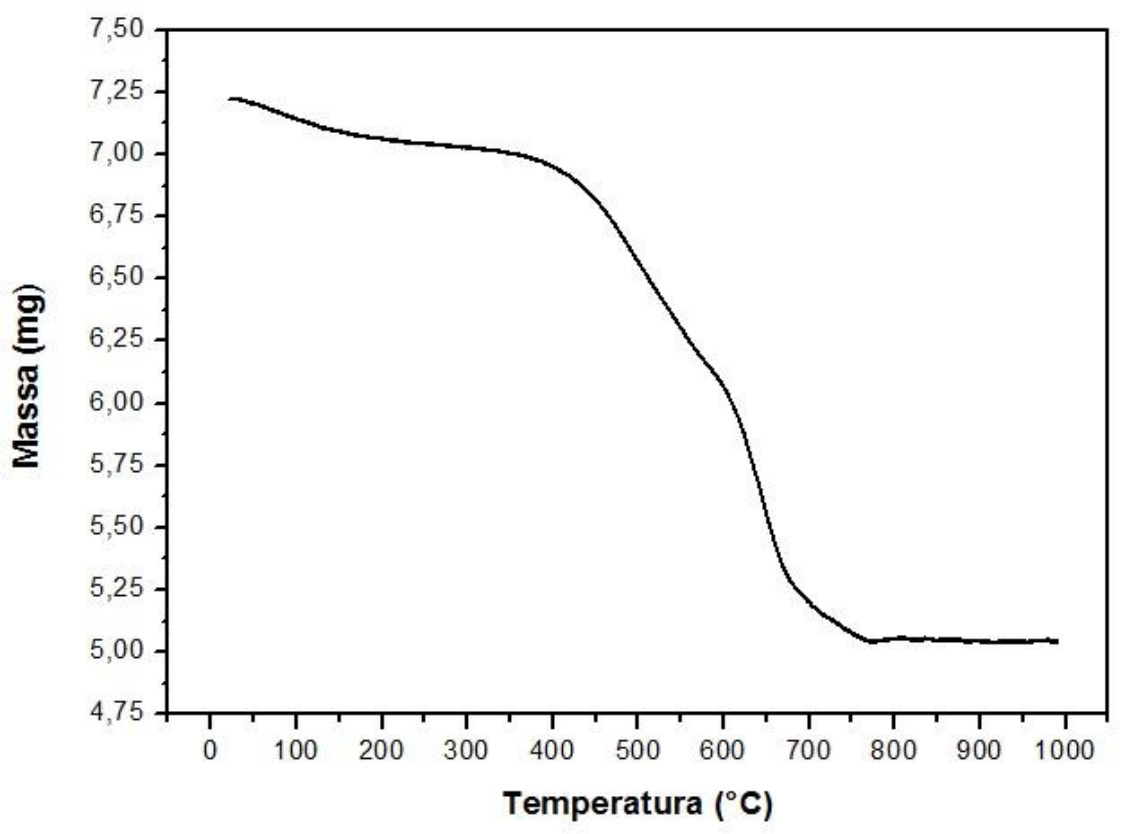

Figura 5.1 - Análise termogravimétrica da resina preliminar constituída de LSCF.

A perda de massa é mais intensa no intervalo de 400 a $700^{\circ} \mathrm{C}$ para a amostra de LSCF analisada. Com relação às transformações dos nitratos precursores para o óxido misto correspondente ao LSCF, ocorreu perda de massa total em torno de $2,18 \mathrm{mg}(16,77 \%$ do material analisado) no intervalo entre aproximadamente 25 e $750^{\circ} \mathrm{C}$ para a curva LSCF, que representa o material com sua estequiometria nominal. 
Entretanto, nesse estudo preliminar da síntese de LSCF, observou-se que houve perda de nitrato de cobalto durante a reação de síntese, fazendo com que ocorresse a formação de fase secundária composta de $\mathrm{Sr}_{2} \mathrm{FeO}_{4}$ (Figura 5.3A). Por este motivo, foi realizado um novo estudo de ATG (Figura 5.2) e DRX (Figura 5.3B) variando o teor de nitrato de cobalto adicionado a mais (em 10 e $20 \%$ ) com relação a composição nominal para compensar a perda ocorrida.

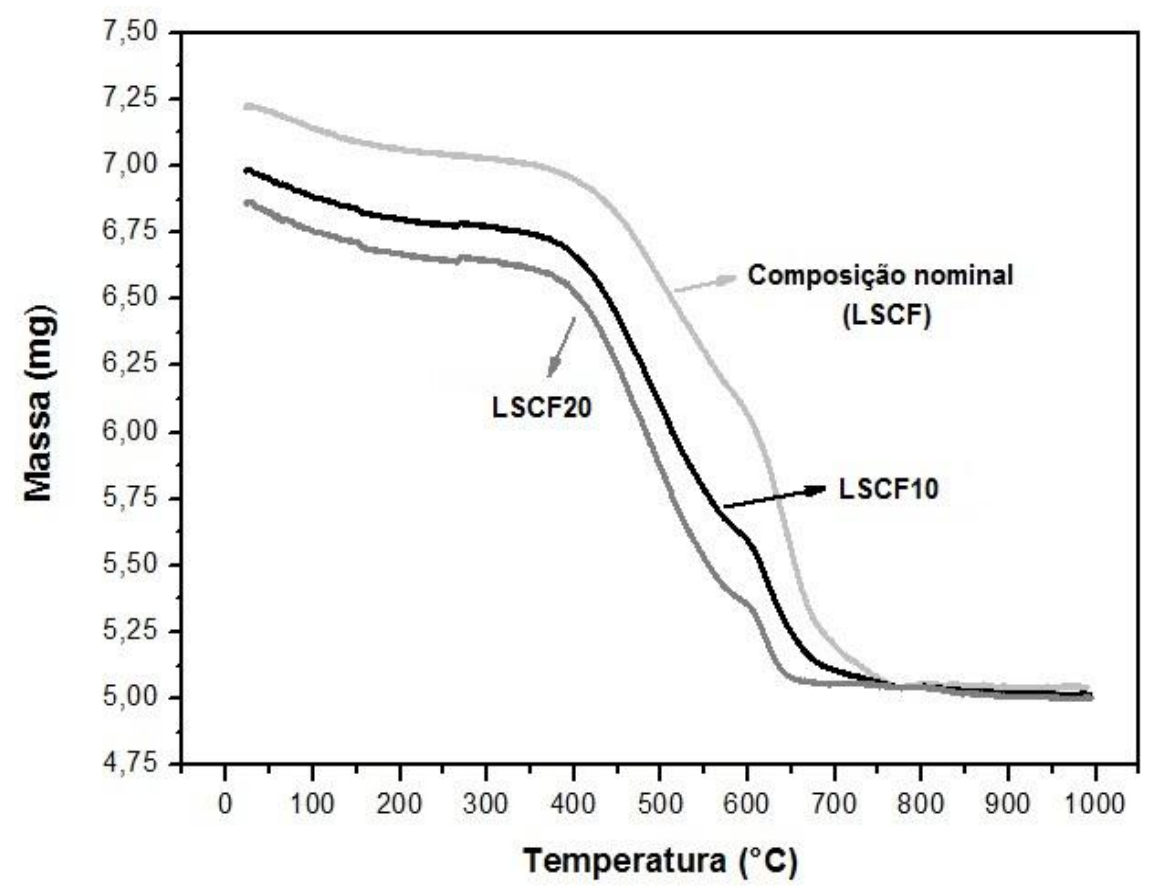

Figura 5.2 - Análise termogravimétrica das resinas variando o teor de cobalto.

A curva nomeada de LSCF10 representa o material sintetizado (LSCF) com adicional de $10 \%$ (em massa) de nitrato de cobalto sobre a composição nominal e a curva LSCF20 com adicional de $20 \%$ (em massa). Esta variação do teor do nitrato de cobalto será discutida na análise do difratograma da Figura 5.3.

Com base na Figura 5.2, a perda de massa é mais significativa no intervalo de 350 a $650^{\circ} \mathrm{C}$ para as composições contendo maior quantidade mássica de nitrato de cobalto. Com relação às transformações dos nitratos precursores para o óxido misto correspondente ao LSCF, ocorreu perda de massa total (Tabela 5.1) em torno de $1,92 \mathrm{mg}(14,77 \%$ do material analisado) no intervalo entre aproximadamente 25 e $750^{\circ} \mathrm{C}$. 
Tabela 5.1 - Perda de massa durante a ATG para as amostras de LSCF.

\begin{tabular}{|c|c|c|c|c|c|}
\hline \multirow{3}{*}{ Amostra } & \multirow{3}{*}{$\begin{array}{c}\text { Intervalo de } \\
\text { Temperatura } \\
\left({ }^{\circ} \mathrm{C}\right)\end{array}$} & \multicolumn{4}{|c|}{ Perda de Massa } \\
\hline & & \multicolumn{2}{|c|}{$(\mathrm{mg})$} & \multicolumn{2}{|c|}{ (\% em massa) } \\
\hline & & Intervalo & Total & Intervalo & Total \\
\hline \multirow{3}{*}{ LSCF } & 25 a 400 & 0,27 & \multirow{3}{*}{2,18} & 2,08 & \multirow{3}{*}{16,77} \\
\hline & 400 a 600 & 0,89 & & 6,85 & \\
\hline & 600 a 750 & 1,02 & & 7,84 & \\
\hline \multirow{3}{*}{ LSCF10 } & 25 a 400 & 0,31 & \multirow{3}{*}{1,92} & 2,38 & \multirow{3}{*}{14,77} \\
\hline & 400 a 600 & 1,08 & & 8,31 & \\
\hline & 600 a 750 & 0,53 & & 4,08 & \\
\hline \multirow{3}{*}{ LSCF20 } & 25 a 400 & 0,33 & \multirow{3}{*}{1,81} & 2,54 & \multirow{3}{*}{13,92} \\
\hline & 400 a 600 & 1,18 & & 9,08 & \\
\hline & 600 a 750 & 0,30 & & 2,30 & \\
\hline
\end{tabular}

De acordo com a Tabela 5.1, confirma-se que com o aumento da quantidade de nitrato de cobalto, ocorreu diminuição na quantidade de massa perdida e uma diminuição de aproximadamente $100^{\circ} \mathrm{C}$ para o término de perda de massa e formação do material de interesse. Com base neste estudo, definiu-se a temperatura de $800^{\circ} \mathrm{C}$ por 4 horas para a síntese dos particulados de interesse.

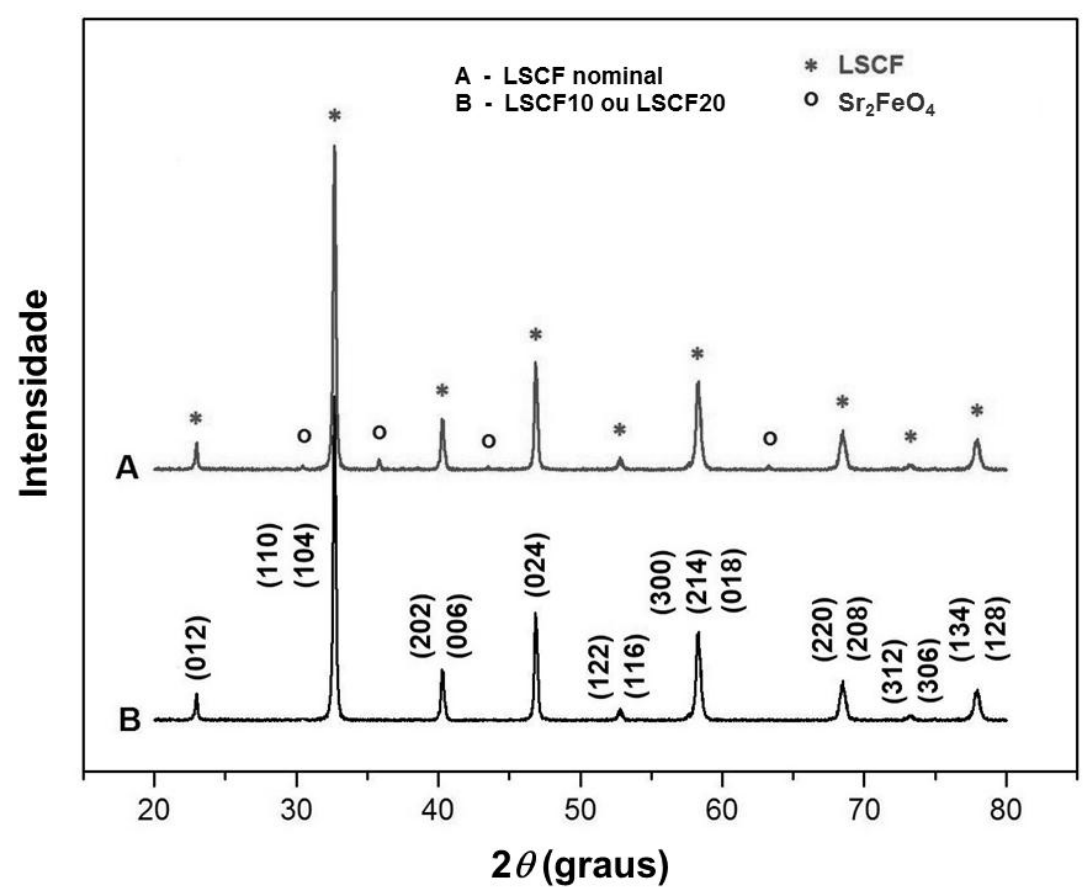

Figura 5.3 - Difratogramas de raios X do LSCF (A) e LSCF10 ou LSCF20 (B). 
Para a amostra calcinada com a composição nominal (Figura 5.3A), identificou-se a existência de duas fases; sendo a principal constituída do óxido misto LSCF e a secundária, de pequena intensidade, constituída de $\mathrm{Sr}_{2} \mathrm{FeO}_{4}$.

Para a amostra calcinada com adicional de $10 \%$ ou $20 \%$ (em massa) de nitrato de cobalto sobre a composição nominal (Figura 5.3B), verificou-se somente a formação da fase LSCF de estrutura cristalina ortorrômbica do tipo pseudo-perovskita após calcinação a $800^{\circ} \mathrm{C}$ por 4 horas.

Os resultados de DRX (Figura 5.3) confirmaram que para evitar a formação da fase $\mathrm{Sr}_{2} \mathrm{FeO}_{4}$ é necessário o adicional de 10\% (em massa) de nitrato de estrôncio sobre a composição nominal. Com isso, a partir deste parágrafo, todas as siglas LSCF se referem a composição com esse adicional de 10\%.

Para a identificação dos índices responsáveis pelos picos (índices de Miller presentes na Figura 5.3B e confirmação da estrutura cristalina, utilizou-se o refinamento por Rietveld (Figura 5.4) em comparação com o arquivo Powder Diffraction File (PDF) de número 48-0124, além de estudos de DRX da literatura técnica para este material ${ }^{(13 ; 14)}$.

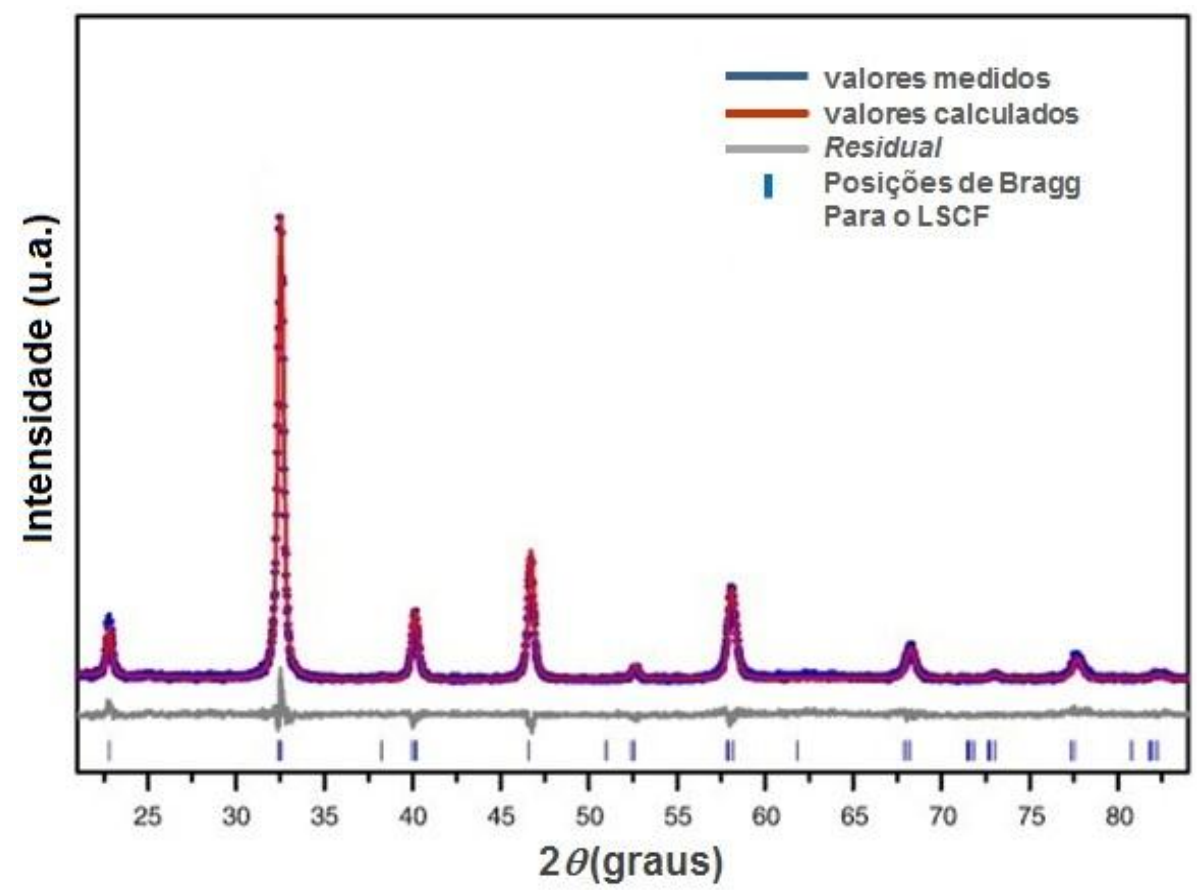

Figura 5.4 - Refinamento pelo método de Rietveld para o LSCF. 
Pelo refinamento Rietveld, confirmou-se que a estrutura cristalina é do tipo ortorrômbica e calculou-se que a composição química obtida para o LSCF é $\left(\mathrm{La}_{0,59} \mathrm{Sr}_{0,41}\right)\left(\mathrm{Co}_{0,21} \mathrm{Fe}_{0,79}\right) \mathrm{O}_{3}$. Esta composição está mais próxima da composição nominal que a obtida por FRX (Tabela 5.2). Por este método confirmou-se também que os desvios padrões referentes à qualidade dos dados obtidos estão entre 1,1 e 1,3; portanto, dentro do máximo aceitável (igual a 3,0) para que o resultado seja considerado confiável ${ }^{(121)}$.

Após a otimização das condições de síntese dos particulados de LSCF pela técnica dos citratos, foram fabricados particulados das três mistura de LSCF e CGO propostas neste trabalho (LSCFCGO13, LSCFCG011 e LSCFCGO31) por mistura de sólidos ou óxidos.

$\mathrm{Na}$ Figura 5.5 são apresentados os difratogramas dos três materiais compósitos obtidos por mistura de óxidos sem a realização de tratamento térmico e, na Figura 5.6, dos particulados de CGO e YSZ comerciais.

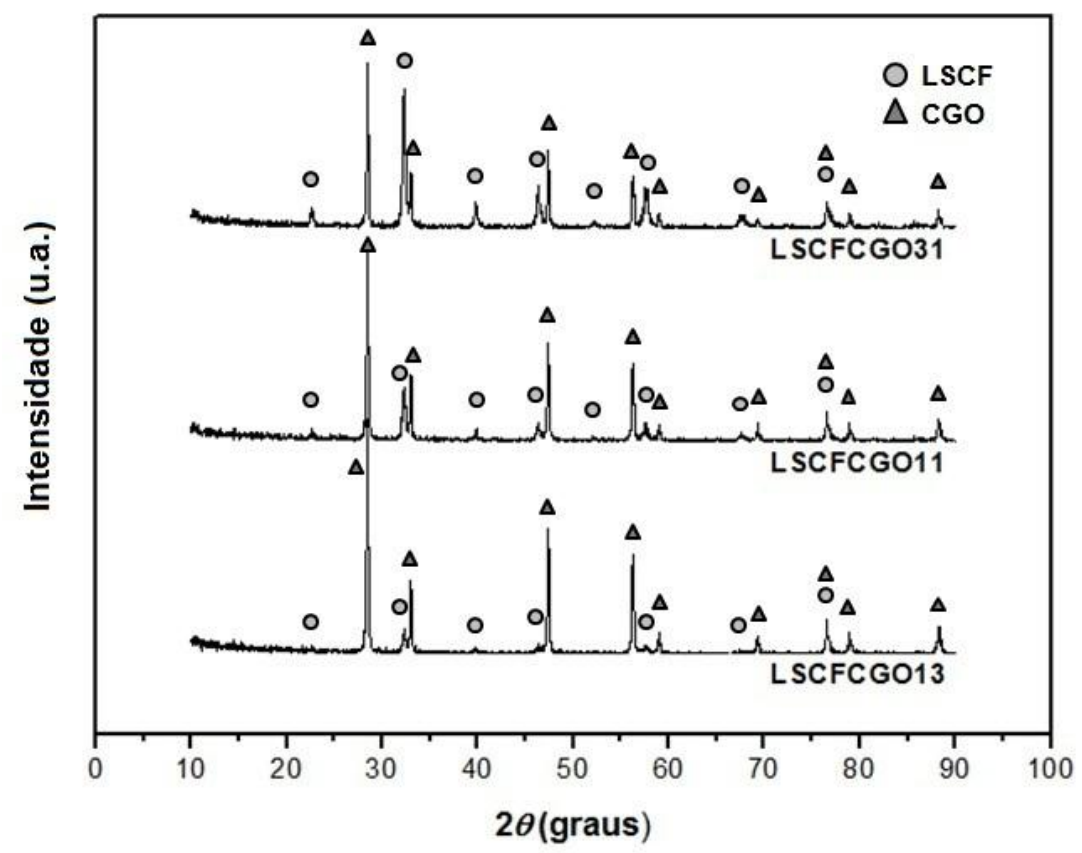

Figura 5.5 - Difratogramas de raios X dos particulados de LSCFCGO.

O difratograma correspondente à amostra LSCFCGO31 confirmou a presença somente das duas fases constituintes da mistura contendo $75 \%$ (em massa) de LSCF e 25\% (em massa) de CGO. 
Os difratogramas das amostras LSCFCGO11 e LSCFCGO13 também confirmaram as fases constituintes de cada mistura.

Com base nestes resultados, à medida que se aumenta a quantidade em massa de CGO no compósito, aumentou a intensidade dos picos correspondentes a este óxido até $2 \theta$ de aproximadamente $60^{\circ}$, diminuindo consequentemente a intensidade dos picos referentes ao LSCF.

$\mathrm{Na}$ Figura 5.6 são apresentados os difratogramas referentes aos particulados de CGO e YSZ comerciais. De acordo com os resultados e com dados da literatura, ambos possuem estrutura do tipo fluorita ${ }^{(67 ; 75)}$.

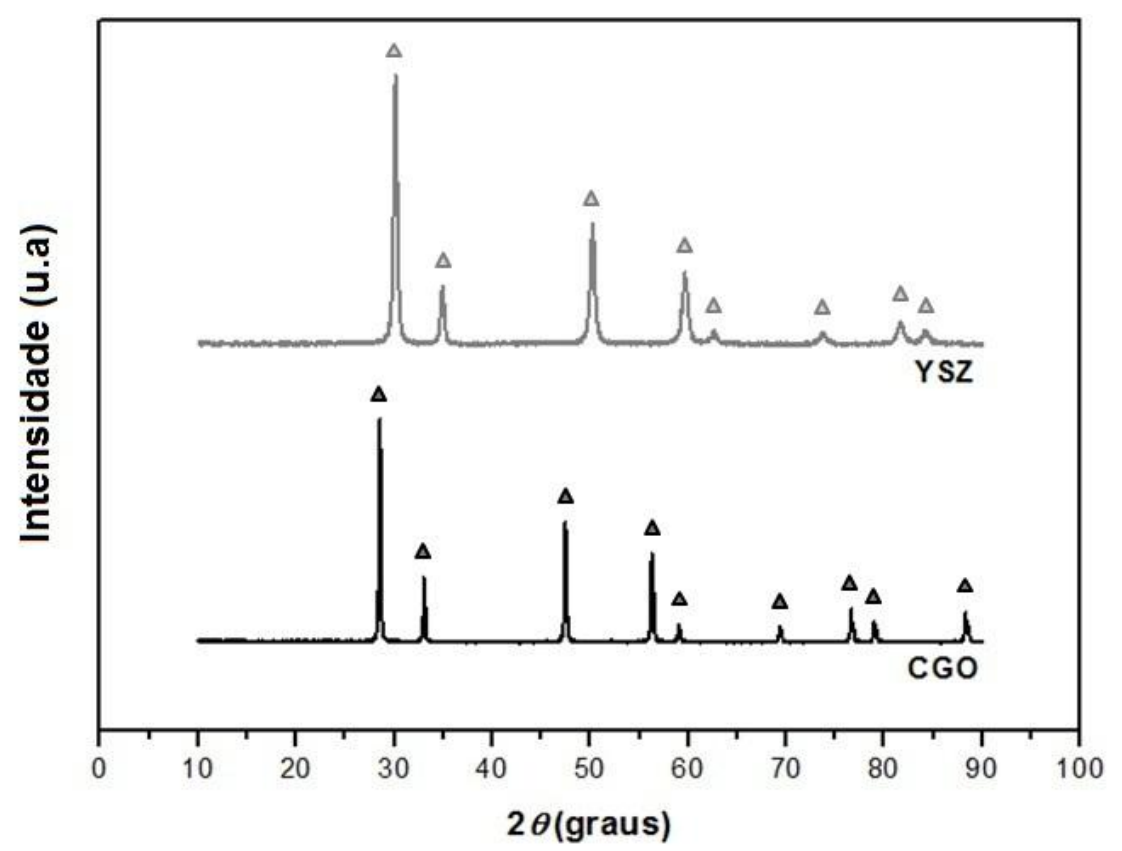

Figura 5.6- Difratogramas de raios X dos particulados de CGO e YSZ.

Após a confirmação da obtenção da fase de interesse para o LSCF, das estruturas dos eletrólitos (CGO e YSZ) e dos difratogramas referentes aos compósitos LSCFCGO, determinou-se a composição química das amostras utilizando a técnica de FRX-EDS. Analisando os resultados da Tabela 5.2, podese concluir que as composições reais estão relativamente próximas às nominais, confirmando particulados sem a presença de fases indesejáveis. 
Tabela 5.2 - Composições químicas das amostras sintetizadas.

\begin{tabular}{ccc}
\hline Amostra & Composição nominal & Composição real \\
\hline LSCF & $\left(\mathrm{La}_{0,60} \mathrm{Sr}_{0,40}\right)\left(\mathrm{Co}_{0,20} \mathrm{Fe}_{0,80}\right) \mathrm{O}_{3}$ & $\left(\mathrm{La}_{0,58} \mathrm{Sr}_{0,42}\right)\left(\mathrm{Co}_{0,21} \mathrm{Fe}_{0,79}\right) \mathrm{O}_{3}$ \\
\hline \multirow{4}{*}{ LSCFCGO31 } & $75 \%$ em massa de & $77 \%$ em massa de \\
& $\left(\mathrm{La}_{0,60} \mathrm{Sr}_{0,40}\right)\left(\mathrm{Co}_{0,20} \mathrm{Fe}_{0,80}\right) \mathrm{O}_{3}$ & $\left(\mathrm{La}_{0,58} \mathrm{Sr}_{0,42}\right)\left(\mathrm{Co}_{0,21} \mathrm{Fe}_{0,79}\right) \mathrm{O}_{3}$ \\
& $25 \%$ em massa de & $23 \%$ massa de \\
& $\left(\mathrm{Ce}_{0,90} \mathrm{Gd}_{0,10}\right) \mathrm{O}_{1,95}$ & $\left(\mathrm{Ce}_{0,90} \mathrm{Gd}_{0,10}\right) \mathrm{O}_{1,95}$ \\
\hline \multirow{3}{*}{ LSCFCGO11 } & $50 \%$ em massa de & $49 \%$ em massa de \\
& $\left(\mathrm{La}_{0,606} \mathrm{Sr}_{0,40}\right)\left(\mathrm{Co}_{0,20} \mathrm{Fe}_{0,80}\right) \mathrm{O}_{3}$ & $\left(\mathrm{La}_{0,58} \mathrm{Sr}_{0,42}\right)\left(\mathrm{Co}_{0,21} \mathrm{Fe}_{0,79}\right) \mathrm{O}_{3}$ \\
& $50 \%$ em massa de & $51 \%$ massa de \\
& $\left(\mathrm{Ce}_{0,90} \mathrm{Gd}_{0,10}\right) \mathrm{O}_{1,95}$ & $\left(\mathrm{Ce}_{0,90} \mathrm{Gd}_{0,10}\right) \mathrm{O}_{1,95}$ \\
\hline & $25 \%$ em massa de & $22 \%$ em massa de \\
LSCFCGO13 & $\left(\mathrm{La}_{0,60} \mathrm{Sr}_{0,40}\right)\left(\mathrm{Co}_{0,20} \mathrm{Fe}_{0,80}\right) \mathrm{O}_{3}$ & $\left(\mathrm{La}_{0,55} \mathrm{Sr}_{0,42}\right)\left(\mathrm{Co}_{0,21} \mathrm{Fe}_{0,79}\right) \mathrm{O}_{3}$ \\
& $75 \% \%$ em massa de & $78 \%$ massa de \\
& $\left(\mathrm{Ce}_{0,90} \mathrm{Gd}_{0,10}\right) \mathrm{O}_{1,95}$ & $\left(\mathrm{Ce}_{0,90} \mathrm{Gd}_{0,10}\right) \mathrm{O}_{1,95}$ \\
\hline
\end{tabular}

A composição real dos particulados de LSCF apresentou uma quantidade percentual (em massa) ligeiramente desviado da composição nominal, em decorrência das etapas calcinação ou mistura em moinho atritor, pois uma fração do material particulado reage com o cadinho no fundo do recipiente e/ou fica aderida aos corpos de moagem (esferas de moagem), ocasionando consequentemente uma perda de massa de LSCF e/ou CGO.

Por granulometria utilizando espalhamento de feixes laser, foi determinado o diâmetro médio equivalente $\left(D_{\text {médio }}\right)$ em função da massa acumulada. Os resultados são apresentados na Tabela 5.3 juntamente com os resultados referentes à área superficial específica $\left(S_{\text {esp }}\right)$ e densidade real ou massa específica ( $\rho$ ) para os particulados de LSCF e LSCFCGO. Os resultados para o óxido misto LSCF e para os compósitos foram comparados com os valores dos particulados de CGO e YSZ comerciais, exceto para densidade real.

A partir dos resultados da Tabela 5.3, se observa que para um tempo de moagem de aproximadamente 3 horas, os valores de $D_{\text {médio }}$ e $S_{\text {esp }}$ do LSCF e compósitos LSCFCGO estão bastante próximos aos valores das mesmas medidas para CGO e YSZ. Para a amostra LSCF, o diâmetro médio de partícula após moagem de 3 horas é de 0,49 $\mu \mathrm{m}$ e a área de superfície específica desses particulados é da ordem de $6,57 \mathrm{~m}^{2} / \mathrm{g}$. Para a realização destas medidas, todos os particulados foram submetidos a peneiramento em malha 200 Mesh. 
Tabela 5.3- Caracterização física dos materiais particulados.

\begin{tabular}{|c|c|c|c|c|c|c|c|}
\hline & & & & & & & \\
\hline & LSCF & LSCFCG031 & LSCFCG011 & LSCFCG013 & CGO & YSZ \\
\hline $\begin{array}{l}D_{\text {médio }}(\mu \mathrm{m}) \\
\text { sem moagem }\end{array}$ & & 64,32 & - & - & - & $\leq 0,5$ & $\leq 0,3$ \\
\hline \multirow{6}{*}{$\begin{array}{l}D_{\text {médio }}(\mu \mathrm{m}) \\
\text { com moagem }\end{array}$} & $1 \mathrm{~h}$ & 8,52 & - & - & - & - & - \\
\hline & $2 \mathrm{~h}$ & 1,51 & - & - & - & - & - \\
\hline & $3 h$ & 0,49 & 0,53 & 0,45 & 0,38 & - & - \\
\hline & $4 h$ & 0,52 & 0,60 & 0,51 & 0,48 & - & - \\
\hline & $5 h$ & 0,48 & 0,55 & 0,52 & 0,45 & - & - \\
\hline & $6 h$ & 0,72 & 0,61 & 0,60 & 0,56 & - & - \\
\hline $\begin{array}{l}\mathrm{S}_{\text {esp }}\left(\mathrm{m}^{2} / \mathrm{g}\right) \\
\text { sem moagem }\end{array}$ & & 2,09 & - & - & - & $5-8$ & $6-9$ \\
\hline \multirow{4}{*}{$\begin{array}{l}\mathrm{S}_{\text {esp }}\left(\mathrm{m}^{2} / \mathrm{g}\right) \\
\text { com moagem }\end{array}$} & $3 h$ & 6,57 & 5,22 & 6,83 & 7,61 & - & - \\
\hline & $4 \mathrm{~h}$ & 5,30 & 5,19 & 5,34 & 5,35 & - & - \\
\hline & $5 \mathrm{~h}$ & 6,42 & 5,79 & 5,26 & 6,74 & - & - \\
\hline & $6 \mathrm{~h}$ & 8,13 & 5,15 & 5,12 & 5,83 & - & - \\
\hline$\rho\left(\mathrm{g} / \mathrm{cm}^{3}\right)$ & & 5,99 & 6,16 & 6,52 & 6,89 & 7,22 & 5,90 \\
\hline
\end{tabular}

Estes resultados estão de acordo com trabalhos publicados ${ }^{(17 ; 18 ; 37 ; 49)}$ que mencionam as características que os materiais particulados necessitam (particulados com diâmetro médio menor ou igual a 0,60 $\mu \mathrm{m}$ e área superficial específica entre 4 e $12 \mathrm{~m}^{2} / \mathrm{g}$ ) para o preparo de suspensões cerâmicas contendo particulados uniformemente dispersos e para a obtenção de camadas micrométricas mais homogêneas sobre os substratos de CGO ou YSZ.

De acordo com a Tabela 5.3, os valores de diâmetros médios dos particulados de LSCF e LSCFCGO misturados por 3 horas em moinho atritor, estão dentro do intervalo de 0,4 a $0,6 \mu \mathrm{m}$, e na faixa de valores que se encontram os diâmetros médios dos materiais comercializados no mercado (Fuel Cell Materials $^{\circledR}$ ), para fabricação de cátodos para ITSOFCs.

Conforme as análises de determinação do diâmetro médio de partícula e área superficial específica, verifica-se que os particulados dos compósitos LSCFCGO11 e LSCFCGO13 apresentaram menor diâmetro médio de partícula e maior área superficial específica quando comparados aos particulados de LSCF e LSCFCGO31. Isso pode ser explicado em decorrência da fração de particulados de LSCF possuir diâmetro médio de partícula de cerca de $0,15 \mu \mathrm{m}$ em média maior do que a fração de particulados de CGO. Segundo Ding et al ${ }^{(121)}$, a medida que diminui o diâmetro médio de partícula, aumenta a reatividade química dos particulados, em decorrência do aumento de sua área superficial específica. 
Apesar dos particulados de CGO possuírem elevada área superficial específica, possui formato esférico que não é apropriado ${ }^{(29)}$ para funcionar como matéria-prima para a formação de camadas de cátodo compósito, pois é necessário modificar a forma das partículas para obter uma área de contato suficiente com o eletrólito sólido. Por esse motivo, o compósito foi preparado por mistura mecânica em moinho atritor entre as partículas de LSCF e CGO.

Os valores das áreas superficiais específicas obtidos pela técnica de adsorção gasosa (teoria de B.E.T.) dos particulados de LSCF e compósitos LSCFCGO estão na mesma ordem de grandeza dos particulados comerciais de CGO e YSZ. Estes resultados são comprovados pelos diâmetros médios das partículas, pois quanto menor seu tamanho, maior é a área superficial específica.

$\mathrm{Na}$ análise por picnometria com gás hélio, foram obtidas as massas específicas ou densidades reais $\left(\mathrm{em} \mathrm{g} / \mathrm{cm}^{3}\right.$ ) dos particulados de LSCF e LSCFCGO. As diferenças entre os valores das densidades reais entre os materiais são significativas, verifica-se um menor valor para o LSCF $\left(5,99 \mathrm{~g} / \mathrm{cm}^{3}\right)$ e valores um pouco maiores para os compósitos, à medida que se adiciona CGO, cuja densidade é de $7,22 \mathrm{~g} / \mathrm{cm}^{3}$.

O teor de carbono denominado de residual foi obtido pela técnica de cromatografia de absorção gasosa (Tabela 5.4) em decorrência dos compostos orgânicos presentes no ácido cítrico e etileno glicol, utilizados como reagentes na síntese do LSCF. Os valores foram obtidos após análise dos particulados de LSCF calcinados em $800,900,1000$ e $1100^{\circ} \mathrm{C}$ por 4 horas e para os compósitos que foram fabricados com particulados de LSCF calcinado a $800^{\circ} \mathrm{C}$ por 4 horas.

Tabela 5.4 - Carbono residual presente nos compostos LSCF.

\begin{tabular}{cccc}
\hline Composto & $\begin{array}{c}\text { Temperatura de } \\
\text { calcinação }(\stackrel{\circ}{ } \mathbf{C})\end{array}$ & $\begin{array}{c}\text { Teor de } \\
\text { carbono (\%) }\end{array}$ & $\begin{array}{c}\text { Desvio } \\
\text { padrão }\end{array}$ \\
\hline \multirow{2}{*}{ LSCF } & 800 & 0,4160 & \\
& 900 & 0,3600 & \\
LSCFCGO31 & 1000 & 0,1980 & \\
LSCFCGO11 & 1100 & 0,0053 & $\pm 0,0001$ \\
LSCFCGO13 & - & 0,3102 & \\
\hline
\end{tabular}


Os resultados de teor de carbono confirmaram que até a $1100^{\circ} \mathrm{C}$ de tratamento térmico (neste caso calcinação), quanto maior a temperatura de calcinação, menor foi a quantidade de carbono residual.

As porcentagens de carbono estão de acordo com o trabalho publicado por Baythoun e Sale ${ }^{(122)}$. Para a remoção do carbono residual no produto final, são necessárias temperaturas superiores a $1000^{\circ} \mathrm{C}$ por longos períodos, pois em temperaturas mais baixas de calcinação, observa-se a presença de carbono livre resultante da decomposição dos citratos durante a etapa de síntese.

Por MEV foi observada a morfologia dos aglomerados dos materiais particulados de estudo. A Figura 5.7 ilustra as micrografias dos particulados de LSCF após calcinação a $800^{\circ} \mathrm{C}$ e moagem por 3 horas (a) e dos materiais compósitos LSCFCGO após mistura em moinho atritor por 3 horas (b, c, d).

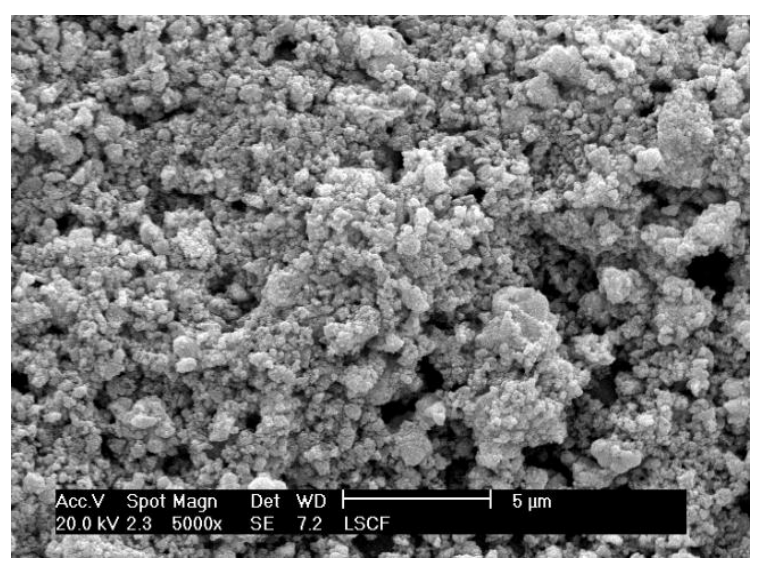

(a)

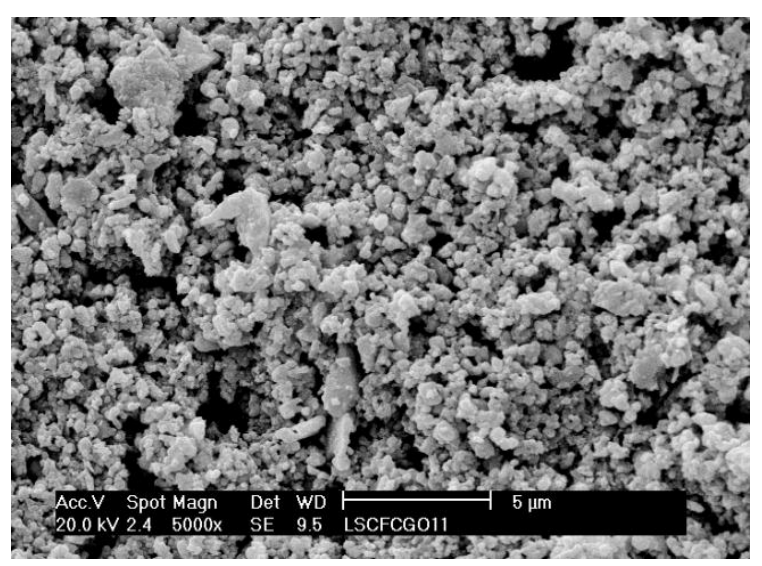

(c)

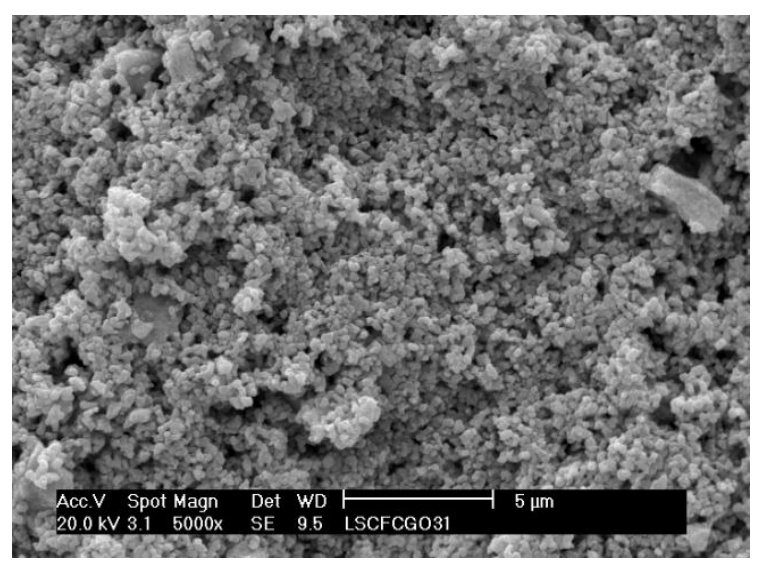

(b)

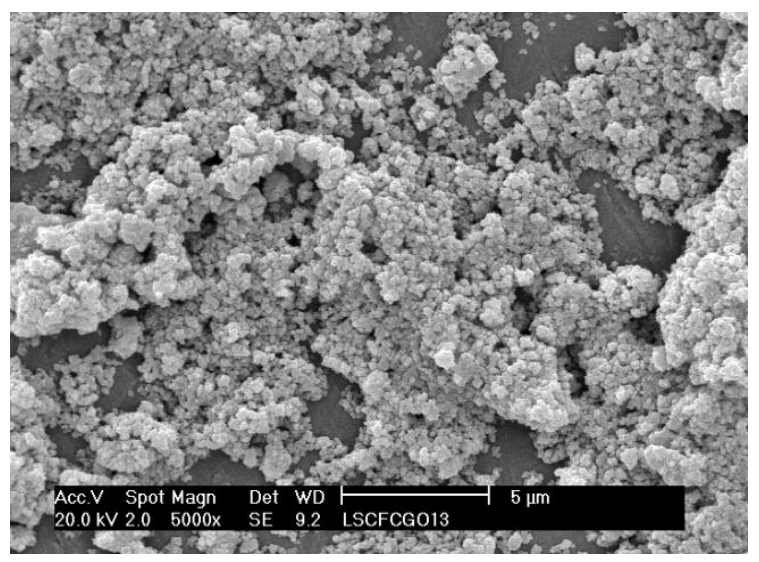

(d)

Figura 5.7 - Micrografias dos particulados de LSCF (a), LSCFCGO31 (b), LSCFCGO11 (c) e LSCFCGO13 (d). 
As micrografias dos compósitos referentes aos materiais particulados de CGO e YSZ são apresentadas na Figura 5.8, revelando a morfologia dos aglomerados constituídos de CGO (a) e YSZ (b), respectivamente.

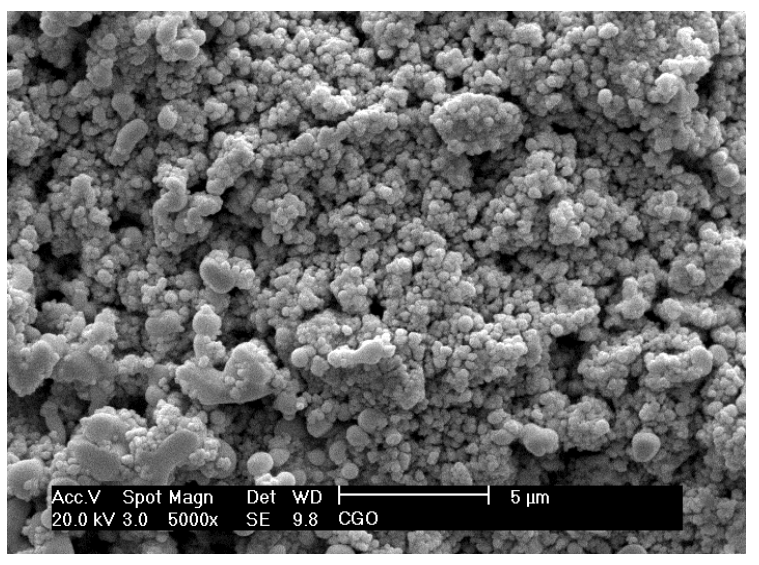

(a)

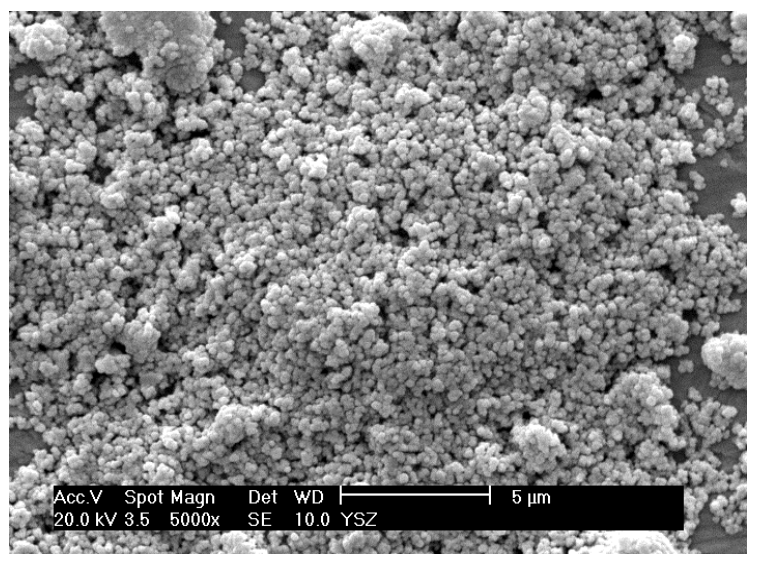

(b)

Figura 5.8 - Micrografias dos particulados de CGO (a) e YSZ (b) comerciais.

As micrografias obtidas para os particulados de LSCF (Figura 5.7a), compósitos LSCFCGO (Figuras 5.7b, 5.7c e 5.7d), CGO (Figura 5.8a) e YSZ (Figura 5.8b) confirmaram particulados na forma de aglomerados homogêneos e que os tamanhos desses aglomerados são, em sua maioria, inferiores a $1 \mu \mathrm{m}$.

Os resultados estão de acordo com os trabalhos de Gaudon et al ${ }^{(123)} \mathrm{e}$ Kakade et al ${ }^{(124)}$, que sintetizaram particulados para eletrodos e eletrólitos de SOFCs pelas técnicas sol-gel e combustão, respectivamente.

As morfologias observadas nas micrografias são semelhantes para os particulados de LSCF e LSCFCGO moídos e peneirados, e estão de acordo com os resultados de tamanho médio de partículas e área superficial específica.

\subsection{Caracterização das cerâmicas}

Para definição das condições de sinterização necessárias para a montagem das células unitárias, realizou-se primeiramente um estudo das cerâmicas obtidas após as conformações dos particulados. 
As curvas representativas da análise de dilatometria (Figura 5.9) foram realizada em pastilhas cerâmicas "a verde" das amostras de LSCF e CGO para a verificação da retração linear em função da temperatura com condição de aquecimento de $5^{\circ} \mathrm{C} / \mathrm{min}$ até $1350^{\circ} \mathrm{C}$ em atmosfera de ar sintético.

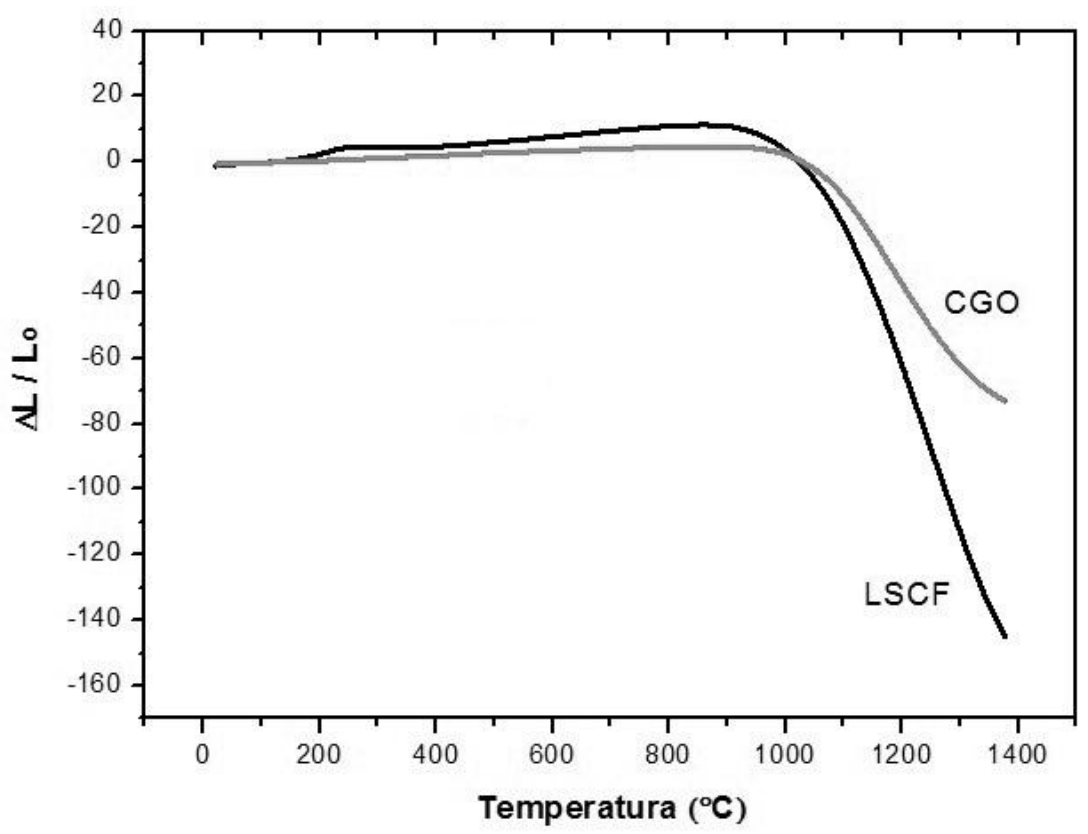

Figura 5.9 - Retração linear das cerâmicas de LSCF e CGO.

Analisando a Figura 5.9, verifica-se o início da retração do LSCF a aproximadamente a $950^{\circ} \mathrm{C}$ e do $\mathrm{CGO}$ a $1050^{\circ} \mathrm{C}$. Tais resultados indicaram que a sinterização dos compósitos LSCFCGO inicia entre 900 e $1000^{\circ} \mathrm{C}$. De acordo com a Figura 5.10, a taxa máxima de retração linear do LSCF ocorre a aproximadamente $1250^{\circ} \mathrm{C}$, e do CGO, a $1180^{\circ} \mathrm{C}$.

Em ambas as curvas, não foram possíveis a visualização da densificação máxima dos materiais, pois a temperatura de operação máxima utilizada no dilatômetro foi de $1350^{\circ} \mathrm{C}$.

De acordo com o resultado de dilatometria, os substratos de CGO devem ser sinterizados acima de $1200^{\circ} \mathrm{C}$, para o aumento da densificação, e acima da máxima taxa de retração linear. Como os eletrólitos devem ser o mais denso possível, em função da condução de íons, temperaturas de sinterização acima de $1400^{\circ} \mathrm{C}$ são comumente utilizadas ${ }^{(38 ; 49 ; 125 ; 126)}$. 


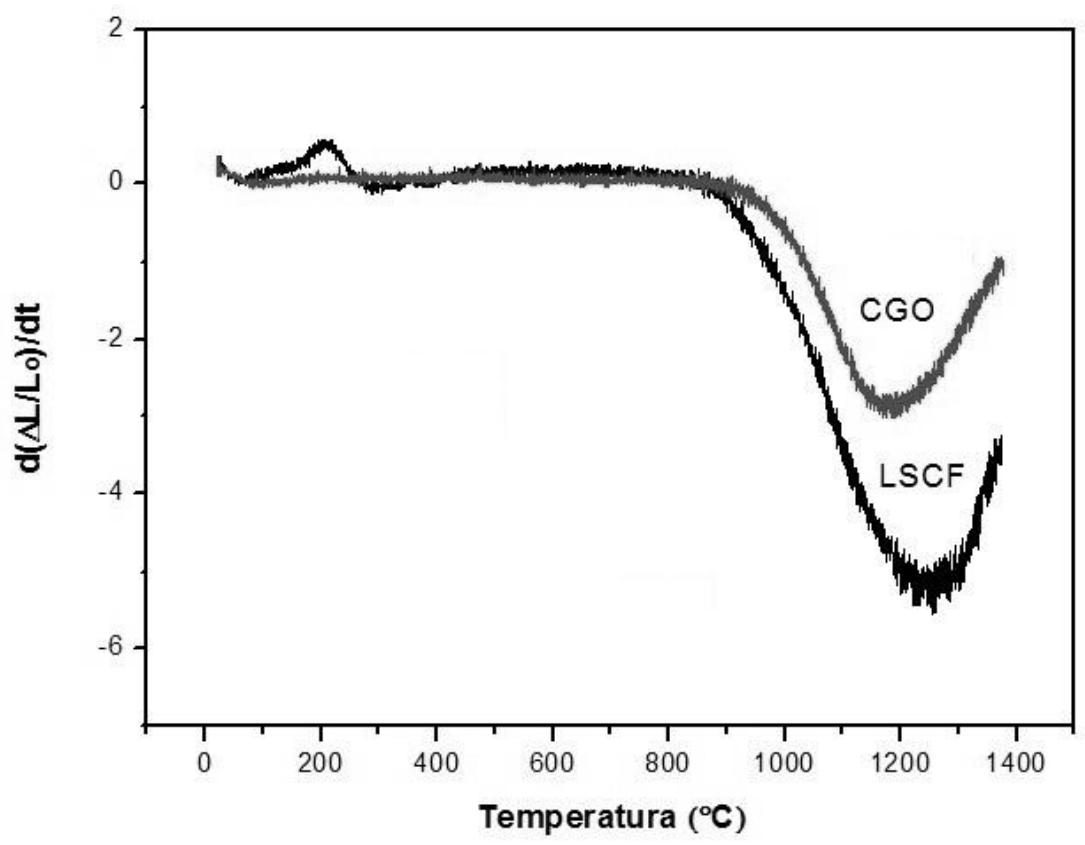

Figura 5.10 - Taxa de retração linear das cerâmicas de LSCF e CGO.

Os resultados comprovaram que para o LSCF e para os compósitos de LSCFCGO, a temperatura de sinterização deve ser inferior a $1200^{\circ} \mathrm{C}$, para a obtenção de cátodos sinterizados com porosidade em torno de 25 a 35\% a fim de permitir a permeabilidade do gás oxidante no interior de todo o componente.

Em todas as amostras preparadas para a sinterização, foram pesadas e anotadas as suas massas secas ( $\mathrm{g}$ ) e medidos os diâmetros ( $\mathrm{mm}$ ) e espessuras (mm), para os cálculos da densidade geométrica dos corpos não sinterizados (denominados "a verde"). Pela Tabela 5.5, verifica-se os valores médios das densidades geométricas antes da sinterização e das densidades teóricas do LSCF (calculado por Rietveld), CGO e YSZ (obtidas nas fichas comerciais).

Tabela 5.5- Valores das densidades geométricas a "verde" e teórica.

\begin{tabular}{ccc}
\hline Amostra & $\begin{array}{c}\text { Densidade Geométrica } \\
\mathbf{a} \text { “verde" }\left(\mathbf{g} / \mathbf{c m}^{\mathbf{3}}\right)\end{array}$ & $\boldsymbol{\rho}_{\mathbf{t}}\left(\mathbf{g} / \mathbf{c m}^{\mathbf{3}}\right)$ \\
\hline LSCF & 2,79 & 6,01 \\
LSCFCGO31 & 3,22 & - \\
LSCFCGO11 & 3,52 & - \\
LSCFCGO13 & 3,90 & - \\
CGO & 4,29 & 7,22 \\
YSZ & 2,77 & 5,90 \\
\hline
\end{tabular}


A densidade teórica da amostra sintetizada de LSCF é $6,01 \mathrm{~g} / \mathrm{cm}^{3}$ e foi calculada pelo método de Rietveld e comparada com os parâmetros de rede disponíveis nos bancos de dados JCPDS de difração de raios $\mathrm{X}$.

As amostras em forma de pastilhas cilíndricas foram sinterizadas a entre 900 e $1500^{\circ} \mathrm{C}$ por 1 hora e a 1150 ou $1250^{\circ} \mathrm{C}$ por 1 e 2 horas. As temperaturas de 1000 a $1300^{\circ} \mathrm{C}$ foram adotadas de acordo com os resultados da análise de dilatometria, pois estão na faixa de maiores retrações lineares, ou seja, na faixa em que está ocorrendo a sinterização. A temperatura de $900^{\circ} \mathrm{C}$ foi adotada somente para comparação quanto aos valores de densidade $\mathrm{e}$ porosidade, pois nesta temperatura, a sinterização ainda se encontra em estágio primário. Por fim, as temperaturas de 1400 e $1500^{\circ} \mathrm{C}$ estão na região de sinterização avançada, conseguindo corpos cerâmicos densos.

Em decorrência do comentado acima e da função distinta dos diferentes materiais estudados, as cerâmicas de LSCF foram sinterizadas entre entre 900 e $1400^{\circ} \mathrm{C}$, as cerâmicas de LSCFCGO foram sinterizadas entre 900 e $1100^{\circ} \mathrm{C}$ e as cerâmicas de CGO ou YSZ foram sinterizadas entre 1200 e $1500^{\circ} \mathrm{C}$. Todas as sinterizações foram realizadas com um patamar de 1 hora nas temperaturas mencionadas acima.

Todas as amostras sinterizadas foram pesadas e anotadas suas massas secas $(\mathrm{g})$ e medidos os diâmetros $(\mathrm{mm})$ e espessuras $(\mathrm{mm})$ para 0 cálculo da densidade geométrica das pastilhas (Tabela 5.6).

Tabela 5.6- Valores das densidades geométricas $\left(\mathrm{g} / \mathrm{cm}^{3}\right)$ dos sinterizados.

\begin{tabular}{ccccccc}
\hline Temperatura (ㅇ) & LSCF & LSCFCGO31 & LSCFCG011 & LSCFCG013 & CGO & YSZ \\
\hline 900 & 3,39 & 3,32 & 4,05 & 4,64 & 4,45 & - \\
1000 & 3,82 & 3,95 & 4,53 & 5,15 & 5,34 & - \\
1050 & 3,95 & - & - & - & - & - \\
1100 & 4,86 & 4,79 & 5,34 & 5,86 & 5,78 & - \\
1200 & 5,83 & - & - & - & 6,67 & 4,30 \\
1250 & - & - & - & - & 6,74 & - \\
1300 & 5,86 & - & - & - & 6,77 & 5,56 \\
1400 & 5,98 & - & - & - & 6,81 & 5,64 \\
1500 & - & - & - & - & 6,98 & 5,82 \\
\hline
\end{tabular}


De acordo com os resultados das densidades das amostras não sinterizadas e sinterizadas, observou-se que, à medida que a temperatura aumentou, ocorreu o aumento nos valores das densidades geométricas.

Após a etapa de sinterização, foram medidas a massa úmida (g) e a imersa $(\mathrm{g})$, de todas as amostras, com o objetivo de calcular a densidade aparente (hidrostática) obtida pelo princípio de Arquimedes (Tabela 5.7).

Tabela 5.7- Valores das densidades aparentes $\left(\mathrm{g} / \mathrm{cm}^{3}\right)$ dos sinterizados.

\begin{tabular}{ccccccc}
\hline Temperatura (ㅇ) & LSCF & LSCFCGO31 & LSCFCG011 & LSCFCGO13 & CGO & YSZ \\
\hline 900 & 3,13 & 3,32 & 4,38 & 4,78 & 4,57 & - \\
1000 & 3,42 & 3,95 & 4,56 & 5,64 & 4,95 & - \\
1050 & 3,64 & - & - & - & - & - \\
1100 & 4,03 & 4,22 & 4,69 & 5,86 & 5,02 & - \\
1200 & 4,87 & - & - & - & 5,80 & 4,85 \\
1250 & - & - & - & - & 6,07 & - \\
1300 & 5,38 & - & - & - & 6,16 & 5,16 \\
1400 & 5,62 & - & - & - & 6,22 & 5,29 \\
1500 & - & - & - & - & 6,34 & 5,32 \\
\hline
\end{tabular}

De acordo com os resultados obtidos das densidades das amostras após sinterização e princípio de Arquimedes, observou-se que, à medida que a temperatura aumentou, ocorreu o aumento nos valores das densidades.

A partir dos valores de densidades (aparente e real) para as amostras de LSCF e LSCFCGO e das densidades (aparente e teórica) para as amostras de CGO e YSZ, foram calculadas as porosidades (expressas em \%) correspondentes de cada material nas diferentes temperaturas de sinterização (Tabela 5.8).

Tabela 5.8 - Porosidades (\%) das cerâmicas sinterizadas.

\begin{tabular}{ccccccc}
\hline Temperatura ( ${ }^{\circ}$ C) & LSCF & LSCFCGO31 & LSCFCG011 & LSCFCGO13 & CGO & YSZ \\
\hline 900 & 47,92 & 46,10 & 32,82 & 30,62 & 36,70 & - \\
1000 & 43,09 & 35,88 & 30,06 & 18,14 & 31,44 & - \\
1050 & 39,43 & - & - & - & - & - \\
1100 & 32,94 & 31,49 & 28,07 & 14,95 & 30,47 & - \\
1200 & 19,47 & - & - & - & 19,67 & 17,80 \\
1250 & - & - & - & - & 15,93 & - \\
1300 & 10,48 & - & - & - & 13,30 & 12,54 \\
1400 & 6,49 & - & - & - & 9,83 & 8,64 \\
1500 & - & - & - & - & 5,26 & 3,90 \\
\hline
\end{tabular}


Os valores encontrados estão muito próximos do esperado, mas significativamente abaixo dos valores reais, devido à presença de porosidade fechada que não pode ser medida pelo princípio de Arquimedes.

Entretanto, verificou-se que os valores de porosidades estão de acordo com a literatura ${ }^{(18 ; 37)}$. As amostras cerâmicas de LSCF necessitam de porosidade de entre 35 e 40\% para exercer com eficiência a função de cátodo da ITSOFC. De acordo com os resultados, é possível obter porosidade de aproximadamente $39 \%$ com uma sinterização a $1050^{\circ} \mathrm{C}$ por 1 hora e de quase $33 \%$ com uma sinterização de $1100^{\circ} \mathrm{C}$ também por 1 hora.

As amostras dos compósitos possuíram porosidades menores a medida que foi aumentando a quantidade de CGO em sua composição. A amostra de CGO pode ser sinterizada entre 1400 e $1500^{\circ} \mathrm{C}$, para possuir uma porosidade abaixo de $10 \%$ e exercer a função de eletrólito ${ }^{(37 ; 99)}$. A amostra de YSZ possui, quando sinterizada a $1500^{\circ} \mathrm{C}$ por 1 hora, porosidade abaixo de $5 \%$.

Os difratogramas de raios $X$ para as amostras de LSCF sinterizadas entre 900 e $1200^{\circ} \mathrm{C}$ são apresentados na Figura 5.11 e para os materiais compósitos constituídos da mistura LSCFCGO e sinterizados entre 1000 e $1100^{\circ} \mathrm{C}$ são apresentados na Figura 5.12 (a), (b) e (c) para as amostras LSCFCGO31 (a), LSCFCGO11 (b) e LSCFCGO13 (c), respectivamente.

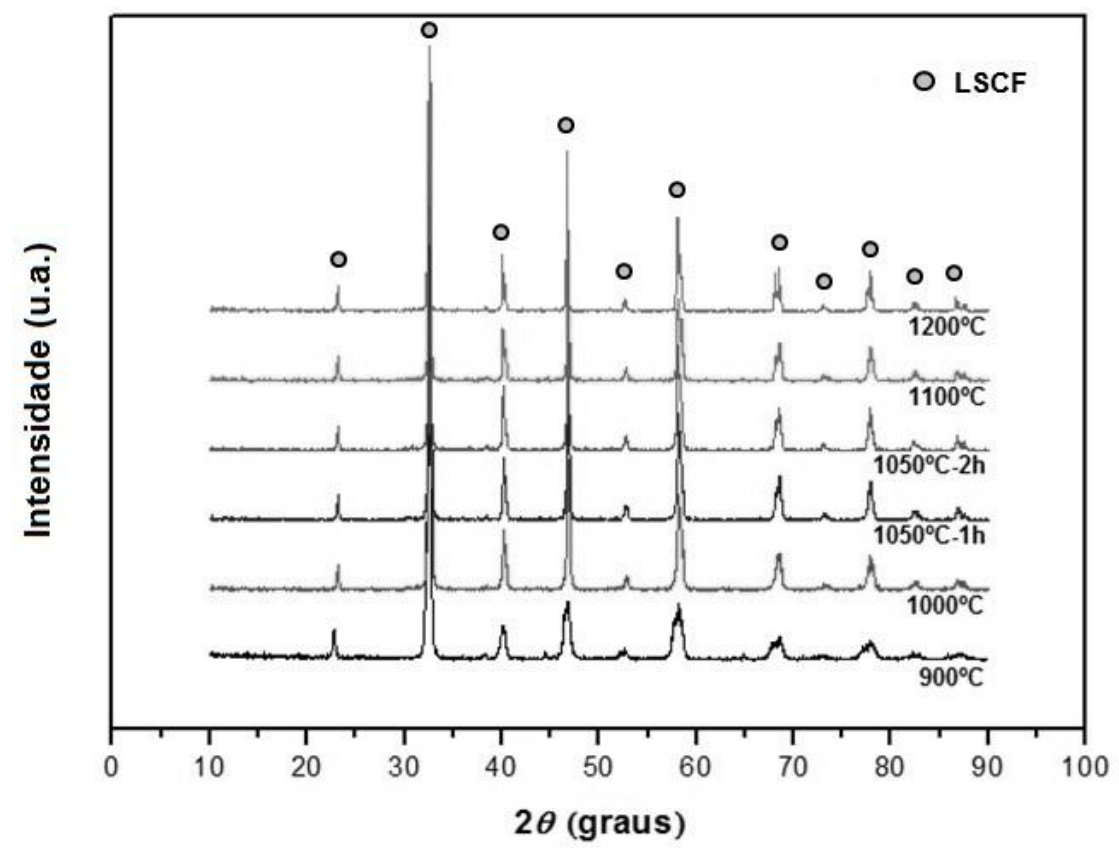

Figura 5.11 - DRX das amostras sinterizadas de LSCF. 


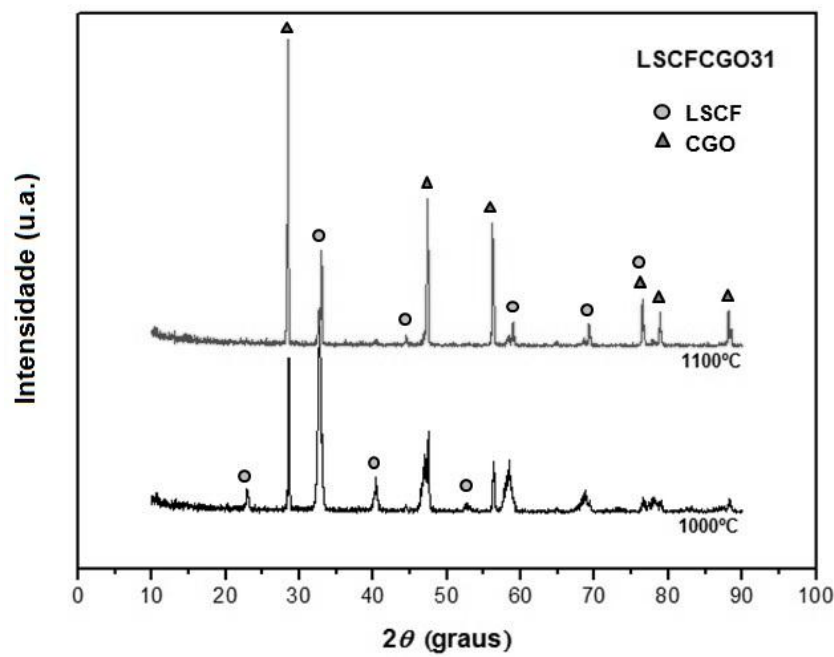

(a)

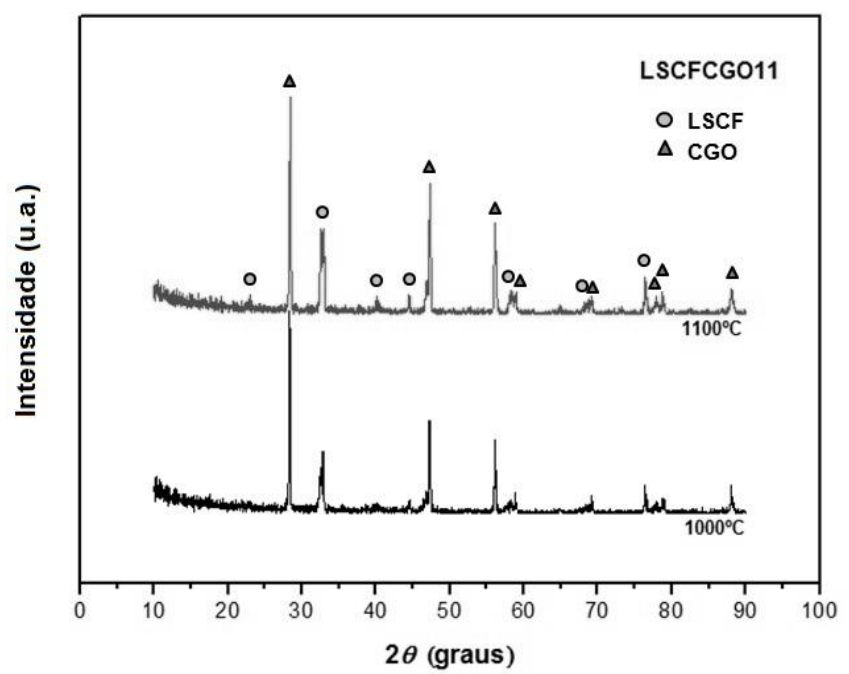

(b)

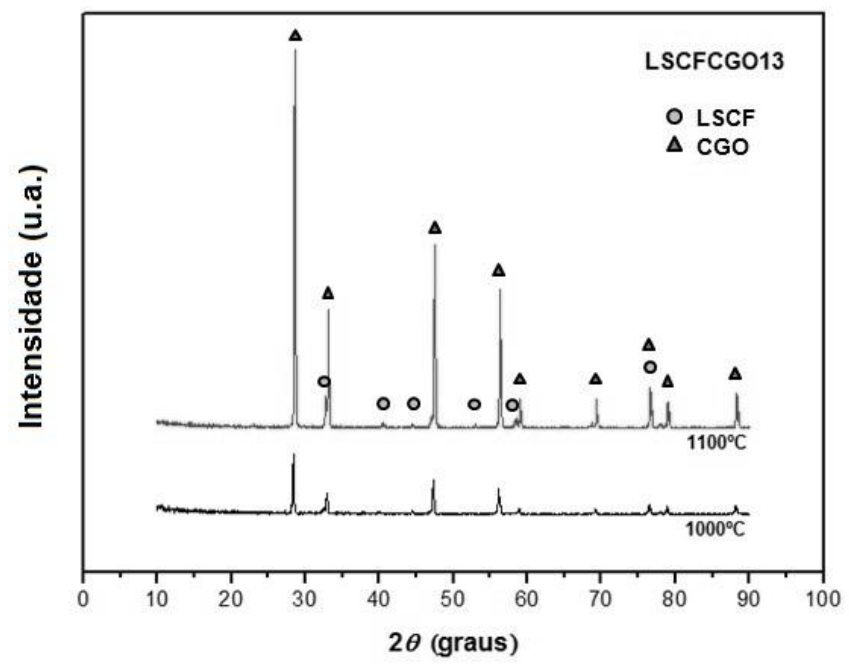

(c)

Figura 5.12 - DRX do LSCFCGO31(a), LSCFCGO11(b) e LSCFCGO13(c). 
A caracterização por DRX para as cerâmicas de LSCF (Figura 5.11) comprovou que, a partir de uma sinterização a $1050^{\circ} \mathrm{C}$ por 1 hora, não ocorreu modificação nos difratogramas e formou-se a estrutura cristalina ortorrômbica, como analisado para os particulados do mesmo material na Figura 5.3.

Os resultados encontrados na Figura 5.12 (a) confirmam que para a obtenção do compósito LSCFCGO31 é necessária uma sinterização de $110^{\circ} \mathrm{C}$ por uma hora, pois a $1050^{\circ} \mathrm{C}$ não se formou a estrutura cristalina mista entre LSCF e CGO. As Figuras 5.12 (b e c) indicam também que para garantir a formação dos compósitos, é necessária uma sinterização de $1100^{\circ} \mathrm{C}$ por pelo menos uma hora. Com base nestes resultados, verificou-se que é possível sinterizar os compósitos na mesma temperatura do cátodo constituído somente de LSCF e obtendo-se um material de mais fácil aderência com o CGO, pois com a sinterização conjunta, aumenta-se o número de contatos na região da TBP.

A caracterização por DRX das cerâmicas de CGO (Figura 5.13) comprovou que, a partir de uma sinterização a $1300^{\circ} \mathrm{C}$ por 1 hora, não ocorreram modificações significativas nos difratogramas e formou-se a estrutura fluorita, como analisado para os particulados do mesmo material na Figura 5.6.

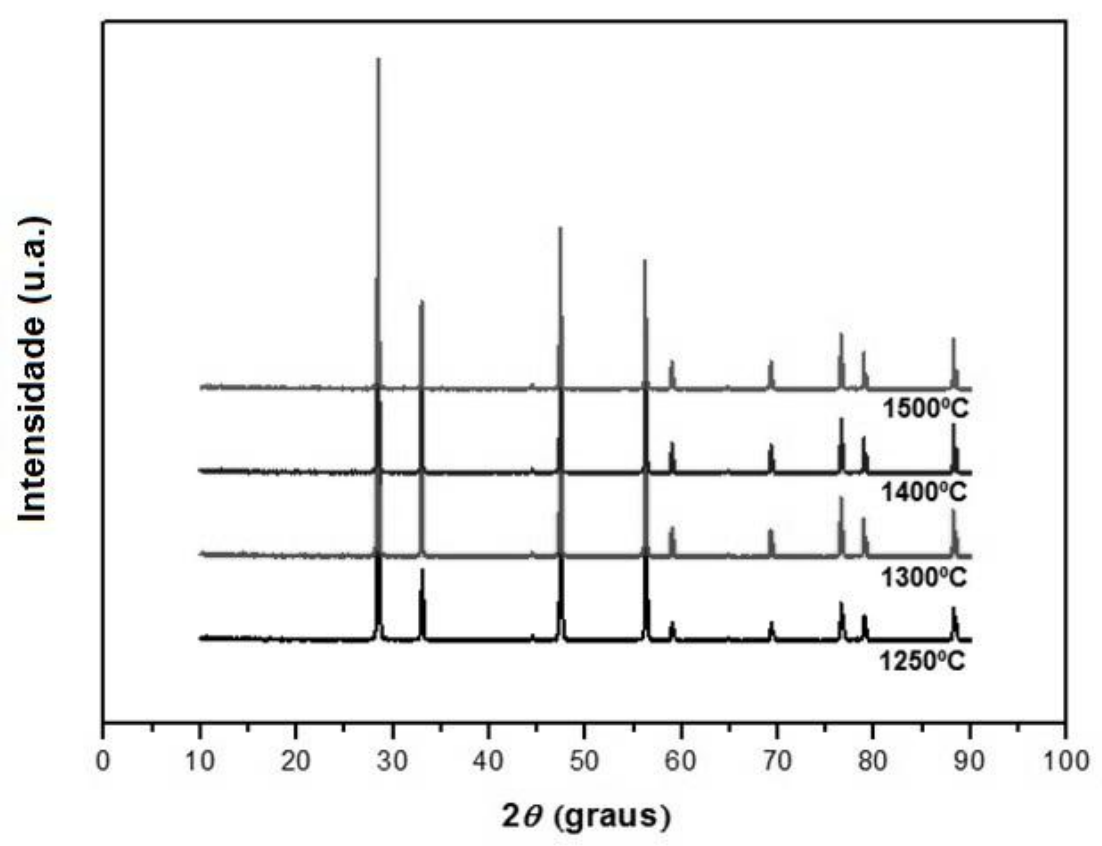

Figura 5.13 - DRX das amostras sinterizadas de CGO. 
Por MEV-EDS observaram-se as superfícies fraturadas das amostras de LSCF sinterizadas, além da identificação quantitativa dos elementos químicos presentes em cada uma. As micrografias estão ordenadas de acordo com a temperatura de sinterização utilizada: LSCF11 sinterizada a 1100ㄷ (Figura 5.14), LSCF12 sinterizada a $1200^{\circ} \mathrm{C}$ (Figura 5.15), LSCF13 sinterizada a $1300^{\circ} \mathrm{C}$ (Figura 5.16) e LSCF14 sinterizada a $1400^{\circ} \mathrm{C}$ (Figura 5.17). Essas amostras foram sinterizadas por 1 hora, nas respectivas temperaturas.
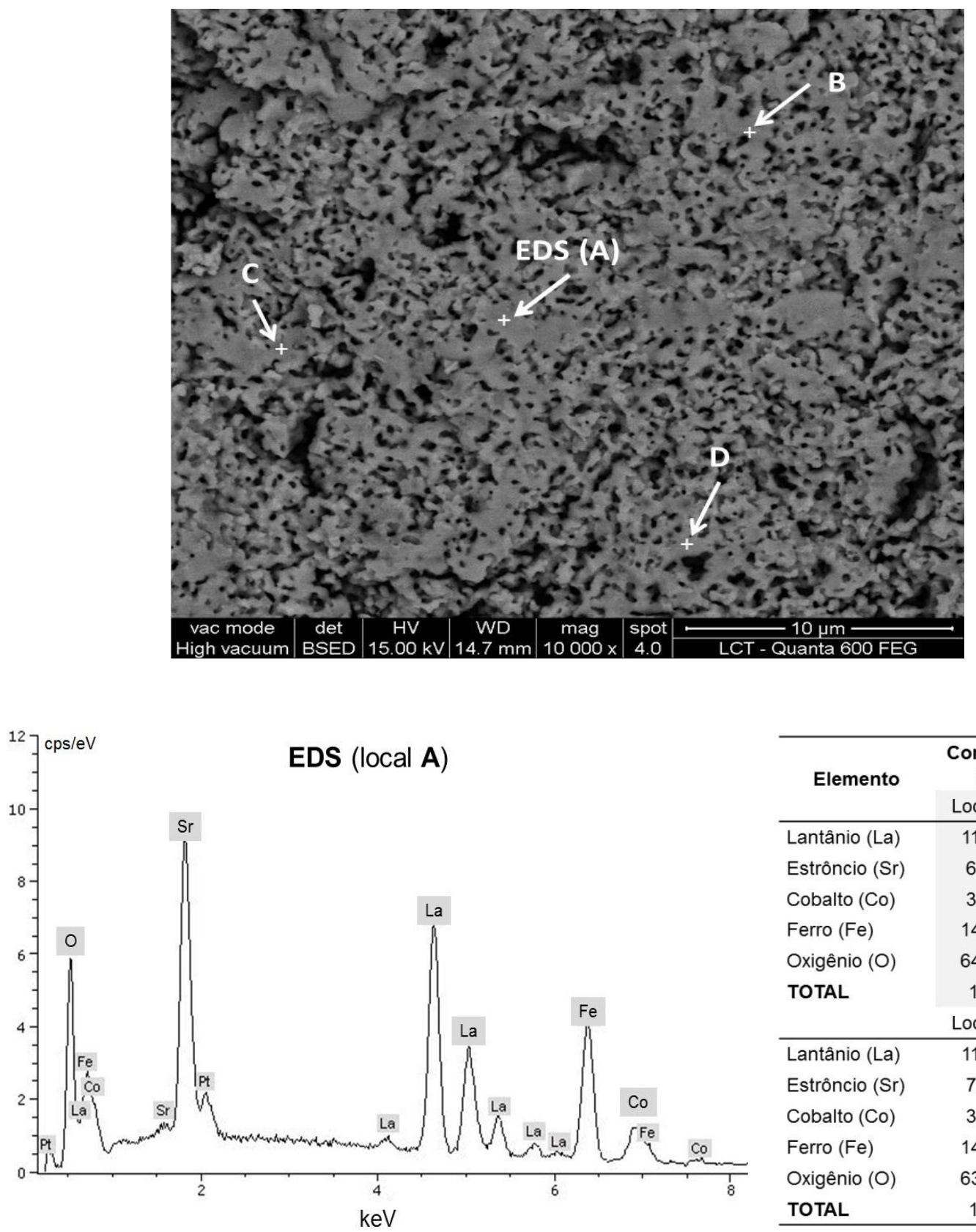

\begin{tabular}{lcc}
\hline Elemento & \multicolumn{2}{c}{$\begin{array}{c}\text { Composição local } \\
\text { (\% atômica) }\end{array}$} \\
& Local A & Local B \\
\hline Lantânio (La) & 11,23 & 8,30 \\
Estrôncio (Sr) & 6,97 & 3,80 \\
Cobalto (Co) & 3,47 & 2,43 \\
Ferro (Fe) & 14,25 & 8,19 \\
Oxigênio (O) & 64,08 & 77,28 \\
TOTAL & 100 & 100 \\
& Local C & Local D \\
\hline Lantânio (La) & 11,48 & 12,98 \\
Estrôncio (Sr) & 7,13 & 8,06 \\
Cobalto (Co) & 3,55 & 4,02 \\
Ferro (Fe) & 14,64 & 16,57 \\
Oxigênio (O) & 63,20 & 58,37 \\
TOTAL & 100 & 100 \\
\hline
\end{tabular}

Figura 5.14 - Micrografia da cerâmica de LSCF11 com identificação quantitativa dos elementos químicos e composições atômicas por EDS. 
Analisando a micrografia da superfície fraturada, referente a amostra LSCF11 (Figura 5.14), verifica-se a presença de porosidade acentuada e distribuída homogeneamente por toda a região observada. A grande quantidade de porosidade indica uma sinterização em estágio inicial, confirmando que a maior parte se classifica como porosidade aberta, ou seja, poros interconectados até a superfície de fratura.
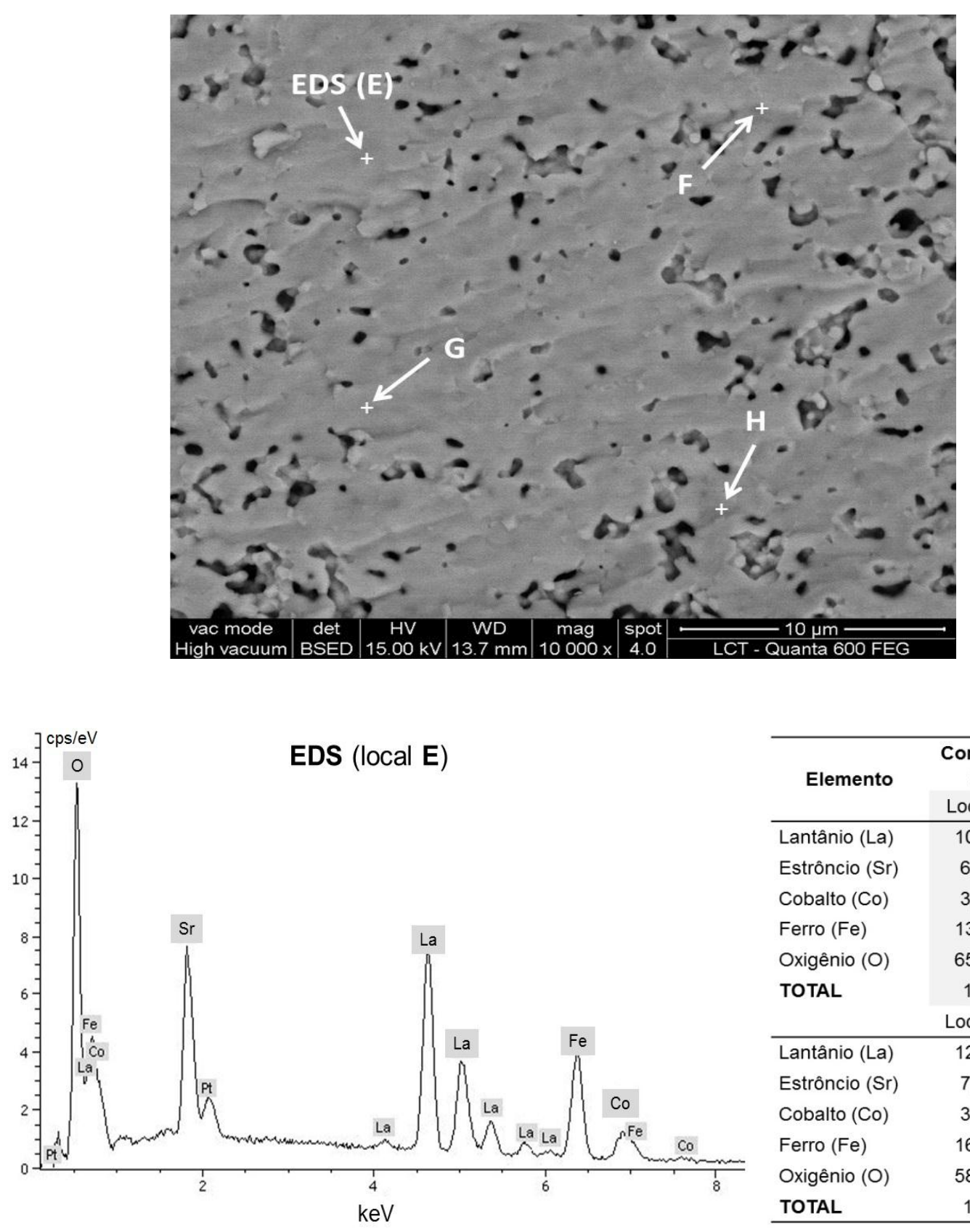

\begin{tabular}{lcc}
\hline \multicolumn{1}{c}{ Elemento } & \multicolumn{2}{c}{$\begin{array}{c}\text { Composição local } \\
\text { (\% atômica) }\end{array}$} \\
& Local E & Local F \\
\hline Lantânio (La) & 10,73 & 13,23 \\
Estrôncio (Sr) & 6,64 & 8,22 \\
Cobalto (Co) & 3,32 & 4,09 \\
Ferro (Fe) & 13,68 & 16,29 \\
Oxigênio (O) & 65,63 & 58,17 \\
TOTAL & 100 & 100 \\
& Local G & Local H \\
\hline Lantânio (La) & 12,86 & 11,61 \\
Estrôncio (Sr) & 7,98 & 7,20 \\
Cobalto (Co) & 3,97 & 3,59 \\
Ferro (Fe) & 16,41 & 14,81 \\
Oxigênio (O) & 58,78 & 62,79 \\
TOTAL & 100 & 100 \\
\hline
\end{tabular}

Figura 5.15 - Micrografia da cerâmica de LSCF12 com identificação quantitativa dos elementos químicos e composições atômicas por EDS. 
A micrografia da superfície fraturada, referente a amostra LSCF12 (Figura 5.15), apresenta porosidade menos acentuada (confirmando os cálculos da Tabela 5.8) quando comparada com o LSCF11, mas também distribuída homogeneamente por toda a região observada. Neste caso, a sinterização avançou para o sentido de fechamento de poros, diminuição da quantidade de poros e aumento da densidade do material.
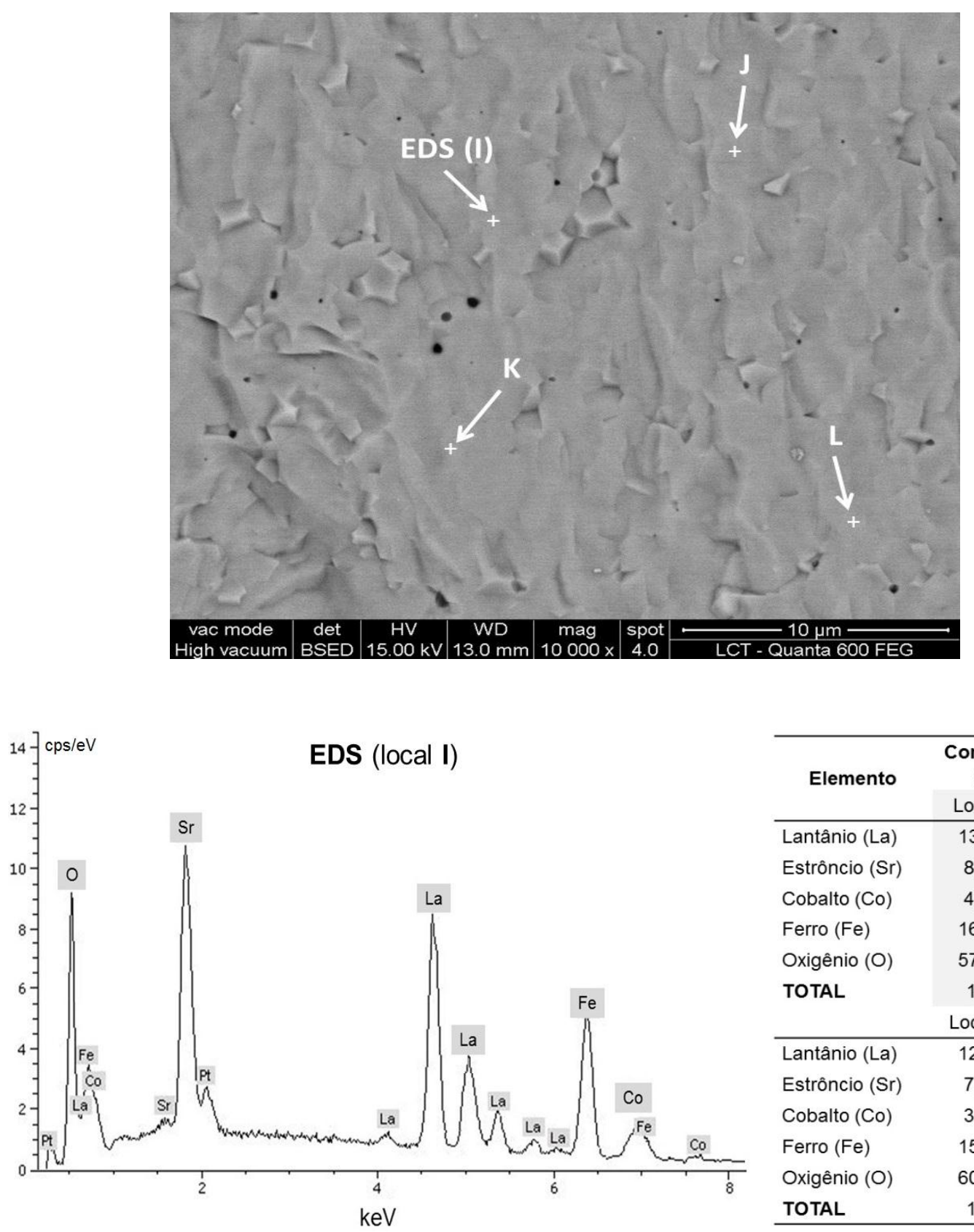

\begin{tabular}{lcc}
\hline \multicolumn{1}{c}{ Elemento } & \multicolumn{2}{c}{$\begin{array}{c}\text { Composição local } \\
\text { (\% atômica) }\end{array}$} \\
& Local I & Local J \\
\hline Lantânio (La) & 13,12 & 12,75 \\
Estrôncio (Sr) & 8,14 & 7,90 \\
Cobalto (Co) & 4,05 & 3,94 \\
Ferro (Fe) & 16,73 & 16,25 \\
Oxigênio (O) & 57,96 & 59,16 \\
TOTAL & 100 & 100 \\
& Local K & Local L \\
\hline Lantânio (La) & 12,35 & 12,49 \\
Estrôncio (Sr) & 7,67 & 7,75 \\
Cobalto (Co) & 3,81 & 3,86 \\
Ferro (Fe) & 15,77 & 15,93 \\
Oxigênio (O) & 60,40 & 59,97 \\
TOTAL & 100 & 100 \\
\hline
\end{tabular}

Figura 5.16 - Micrografia da cerâmica de LSCF13 com identificação quantitativa dos elementos químicos e composições atômicas por EDS. 
Para a micrografia da superfície de fratura, referente a amostra LSCF13 (Figura 5.16), verifica-se pouca porosidade quando comparada com as anteriores (Figuras 5.14 e 5.15), além de poros com menor dimensão e morfologia se aproximando da forma esférica, confirmando o avanço de estágio da sinterização. Neste caso, a sinterização seguiu para o sentido de fechamento completo de poros e aumento da densidade do material.
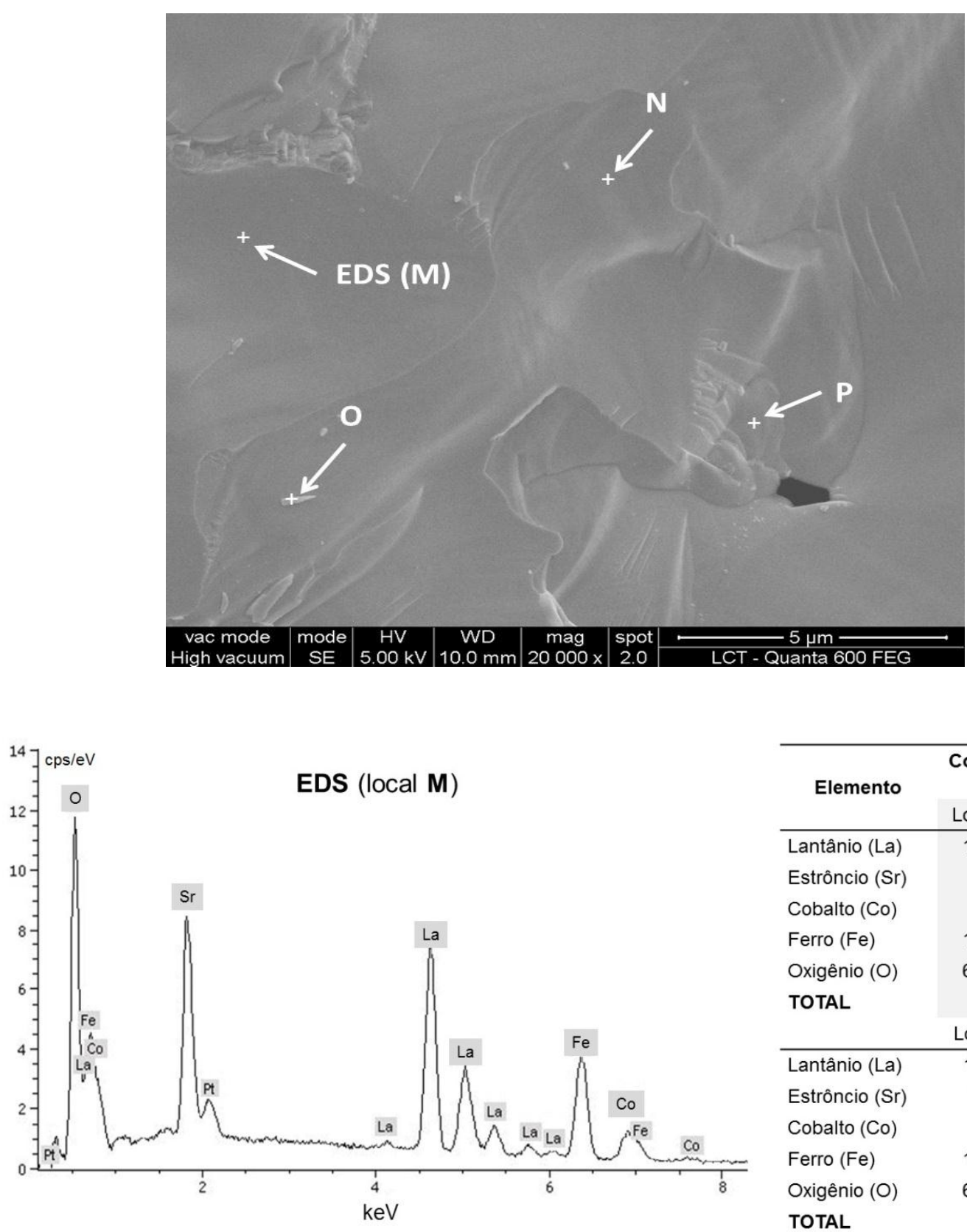

\begin{tabular}{lcc}
\hline \multirow{1}{*}{ Elemento } & \multicolumn{2}{c}{$\begin{array}{c}\text { Composição local } \\
(\% \text { atômica })\end{array}$} \\
& Local M & Local N \\
\hline Lantânio (La) & 12,46 & 12,36 \\
Estrôncio (Sr) & 7,73 & 7,66 \\
Cobalto (Co) & 3,85 & 3,82 \\
Ferro (Fe) & 15,89 & 15,76 \\
Oxigênio (O) & 60,07 & 60,40 \\
TOTAL & 100 & 100 \\
& Local O & Local P \\
\hline Lantânio (La) & 11,55 & 12,24 \\
Estrôncio (Sr) & 7,24 & 7,59 \\
Cobalto (Co) & 3,56 & 3,78 \\
Ferro (Fe) & 14,72 & 15,61 \\
Oxigênio (O) & 62,93 & 60,78 \\
TOTAL & 100 & 100 \\
\hline
\end{tabular}

Figura 5.17 - Micrografia da cerâmica de LSCF14 com identificação quantitativa dos elementos químicos e composições atômicas por EDS. 
Finalmente, para a micrografia da superfície de fratura referente a amostra LSCF14 (apresentada na Figura 5.17), verifica-se uma superfície de fratura bastante densa e com a presença de um poro isolado e remanescente da sinterização. Neste caso, a sinterização resultou em um material muito denso, mas ainda contendo uma pequena fração de porosidade (porosidade fechada).

Em decorrência disso e da necessidade de fabricação de cátodos com porosidade suficiente (entre 30 e 40\%) para a passagem do gás oxigênio até a interface entre o cátodo e o eletrólito, os materiais utilizados como cátodos são sinterizados atualmente entre 1050 e no máximo $1200^{\circ} \mathrm{C}$ por 1 ou 2 horas.

Comparando os resultados referentes às amostras de LSCF, com relação à identificação quantitativa dos elementos químicos presentes em cada uma, verificou-se que as proporções entre cada elemento químico não variaram de forma significativa entre as amostras analisadas. Em todos os pontos (composições locais) demarcados entre as Figuras 5.14 e 5.17, verificou-se que o lantânio variou 4,93\% entre 1100 e $1400^{\circ} \mathrm{C}$. Nesta faixa de temperatura, o estrôncio varia $4,42 \%$, o cobalto $1,66 \%$, o ferro $8,54 \%$ e o oxigênio $6,12 \%$. Todas as variações percentuais são expressas em \% atômicas.

Com relação a cada elemento químico constituinte do LSCF e suas diferentes temperaturas de sinterizações, a Tabela 5.9 contém os valores estatísticos de cada elemento quanto a variação com relação a cada temperatura de sinterização, além das variações médias $(\bar{X})$ e respectivos desvios padrões $(\boldsymbol{\sigma})$.

De acordo com a Tabela 5.9, verifica-se que não ocorrera variações percentuais (\% atômica) consideradas significativas, pela análise por energia dispersiva, que possa prejudicar o desempenho eletroquímico das amostras.

Os resultados comprovaram a homogeneidade das amostras de LSCF sinterizadas entre 1100 e $1400^{\circ} \mathrm{C}$ por 1 hora. Verificou-se também que, no geral, a densificação diminuiu a variação percentual atômica dos elementos analisados. Esse fenômeno pode ser explicado em decorrência da presença de porosidade (fechada ou aberta) dificultar consideravelmente a homogeneização dos elementos químicos na estrutura interna de cada material. 
Tabela 5.9 - Variações de composição, médias e desvios padrões das amostras de LSCF sinterizadas a 1100, 1200, 1300 e $1400^{\circ} \mathrm{C}$ por 1 hora.

\begin{tabular}{|c|c|c|c|c|}
\hline \multirow{2}{*}{ Elemento } & \multirow{2}{*}{$\mathrm{T}\left({ }^{\circ} \mathrm{C}\right)$ sinterização } & \multicolumn{3}{|c|}{ Composição local (\% atômica) } \\
\hline & & Variação & $\bar{X}$ & $\bar{\sigma}$ \\
\hline \multirow{4}{*}{ Lantânio (La) } & 1100 & 4,68 & \multirow{4}{*}{2,21} & \multirow{4}{*}{1,58} \\
\hline & 1200 & 2,50 & & \\
\hline & 1300 & 0,77 & & \\
\hline & 1400 & 0,91 & & \\
\hline \multirow{4}{*}{ Estrôncio (Sr) } & 1100 & 4,26 & \multirow{4}{*}{1,70} & \multirow{4}{*}{1,54} \\
\hline & 1200 & 1,58 & & \\
\hline & 1300 & 0,47 & & \\
\hline & 1400 & 0,49 & & \\
\hline \multirow{4}{*}{ Cobalto (Co) } & 1100 & 1,59 & \multirow{4}{*}{0,72} & \multirow{4}{*}{0,54} \\
\hline & 1200 & 0,77 & & \\
\hline & 1300 & 0,24 & & \\
\hline & 1400 & 0,29 & & \\
\hline \multirow{4}{*}{ Ferro (Fe) } & 1100 & 8,38 & \multirow{4}{*}{3,09} & \multirow{4}{*}{3,18} \\
\hline & 1200 & 2,73 & & \\
\hline & 1300 & 0,96 & & \\
\hline & 1400 & 0,28 & & \\
\hline \multirow{4}{*}{ Oxigênio (O) } & 1100 & 5,71 & \multirow{4}{*}{3,97} & \multirow{4}{*}{2,79} \\
\hline & 1200 & 7,46 & & \\
\hline & 1300 & 2,44 & & \\
\hline & 1400 & 0,28 & & \\
\hline
\end{tabular}

Em seguida, observam-se as superfícies fraturadas das amostras de LSCFCGO sinterizadas, além da identificação quantitativa de todos os elementos químicos presentes em cada um dos compósitos. Neste caso, as micrografias estão ordenadas de acordo com a proporção de LSCF e CGO na constituição de cada material compósito: LSCFCGO31 (Figuras 5.18 e 5.19), LSCFCGO11 (Figuras 5.20 e 5.21) e LSCFCGO13 (Figuras 5.22 e 5.23). Entretanto, dentro de cada proporção, as amostras também estão ordenadas pela temperatura de sinterização utilizada. Cada amostra foi sinterizada a 1100 e 1200드 por 1 hora. 

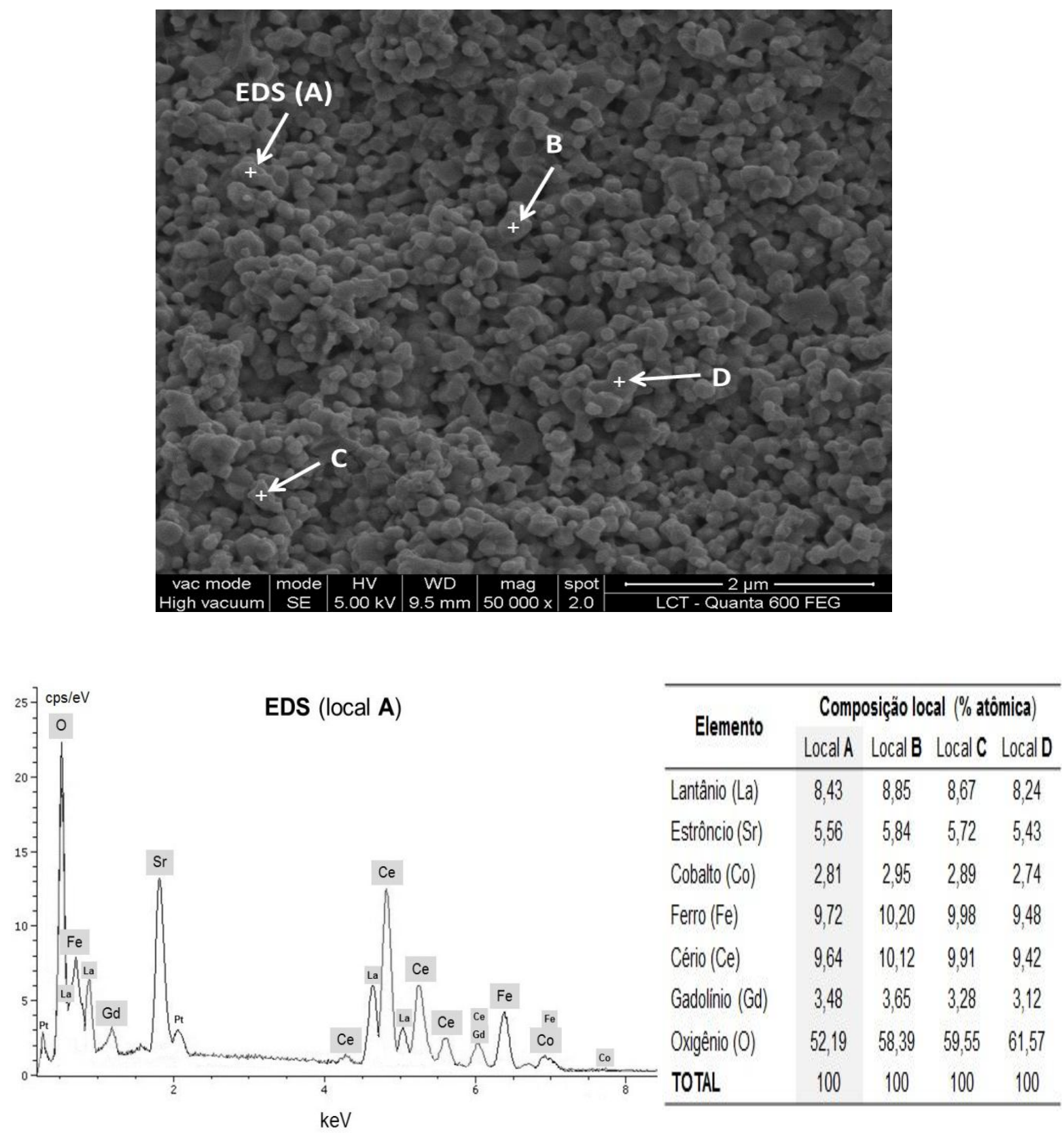

Figura 5.18 - Micrografia da cerâmica de LSCFCGO3111 com identificação quantitativa dos elementos químicos e composições atômicas por EDS.

Analisando a micrografia da superfície fraturada, referente a amostra LSCFCGO3111 (figura anterior), verifica-se a presença de porosidade acentuada e distribuída homogeneamente por toda a região observada. A grande quantidade de porosidade indicou uma sinterização em estágio inicial, confirmando que a maior parte se classifica como porosidade aberta, ou seja, poros interconectados até a superfície de fratura. 
Comparando os resultados das amostras de LSCFCGO3111, com relação a identificação quantitativa dos elementos químicos, verificou-se que as proporções entre cada elemento não variaram de forma significativa entre as diversas regiões analisadas. Em todos os pontos, determinou-se que o lantânio variou $0,61 \%$ (\% atômica), o estrôncio $0,41 \%$, o cobalto 0,21\%, o ferro $0,72 \%$, o cério $0,64 \%$, o gadolínio $0,53 \%$ e o oxigênio $9,38 \%$.
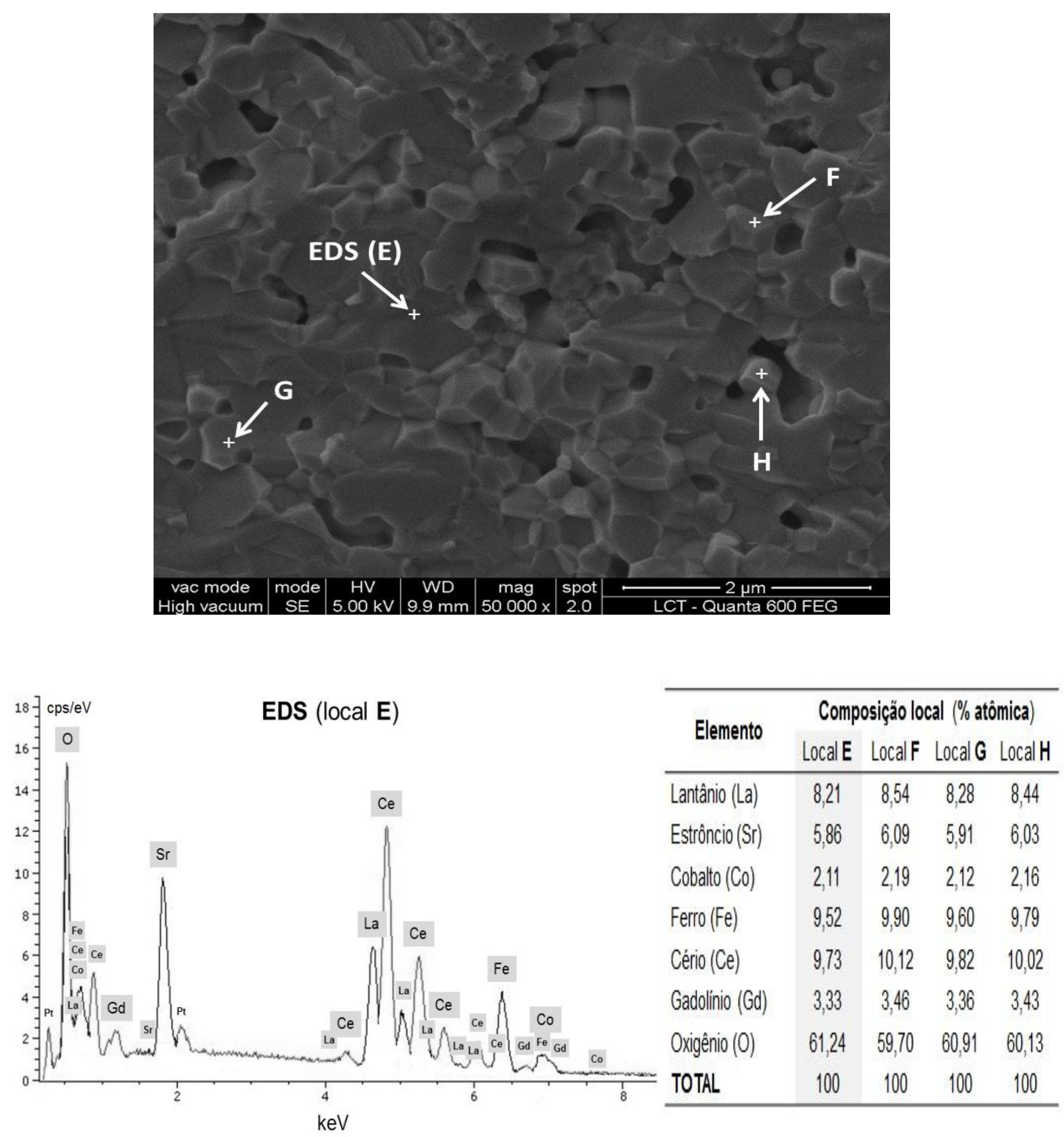

Figura 5.19- Micrografia da cerâmica de LSCFCGO3112 com identificação quantitativa dos elementos químicos e composições atômicas por EDS. 
Verificando as amostras do compósito LSCFCGO3112, também com relação a identificação quantitativa dos elementos químicos presentes, verificouse que as proporções entre cada elemento não variaram de forma significativa. Em todos os pontos, determinou-se que o lantânio variou 0,33\% (\% atômica), o estrôncio $0,23 \%$, o cobalto $0,08 \%$, o ferro $0,38 \%$, o cério $0,39 \%$, o gadolínio $0,13 \%$ e o oxigênio $1,54 \%$.
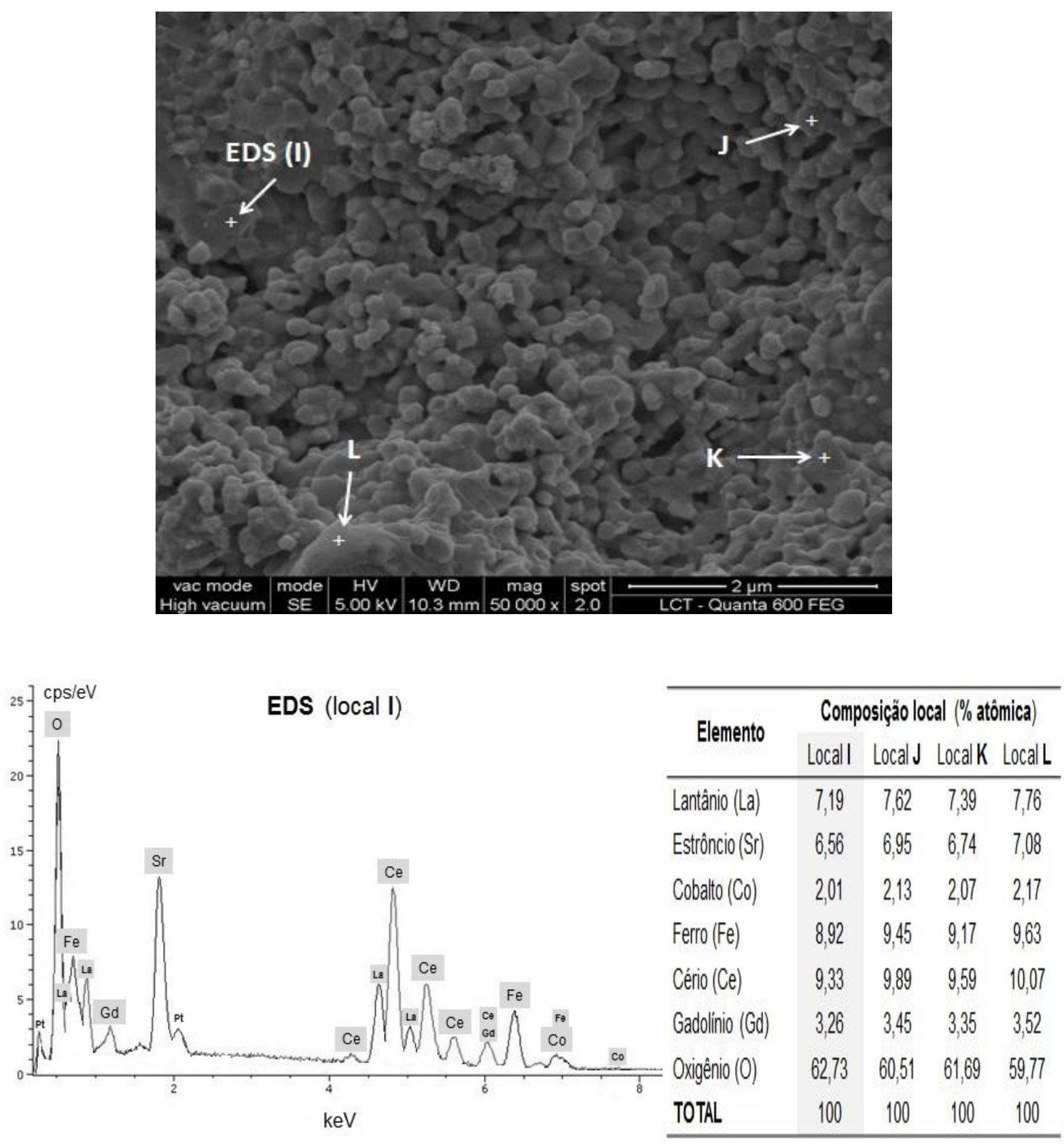

Figura 5.20 - Micrografia da cerâmica de LSCFCGO1111 com identificação quantitativa dos elementos químicos e composições atômicas por EDS. 
Analisando a micrografia da superfície fraturada, referente a amostra LSCFCGO1111, verifica-se a presença de porosidade acentuada e distribuída homogeneamente por toda a região observada. A grande quantidade de porosidade indica uma sinterização em estágio inicial, confirmando que a maior parte se classifica como porosidade aberta.
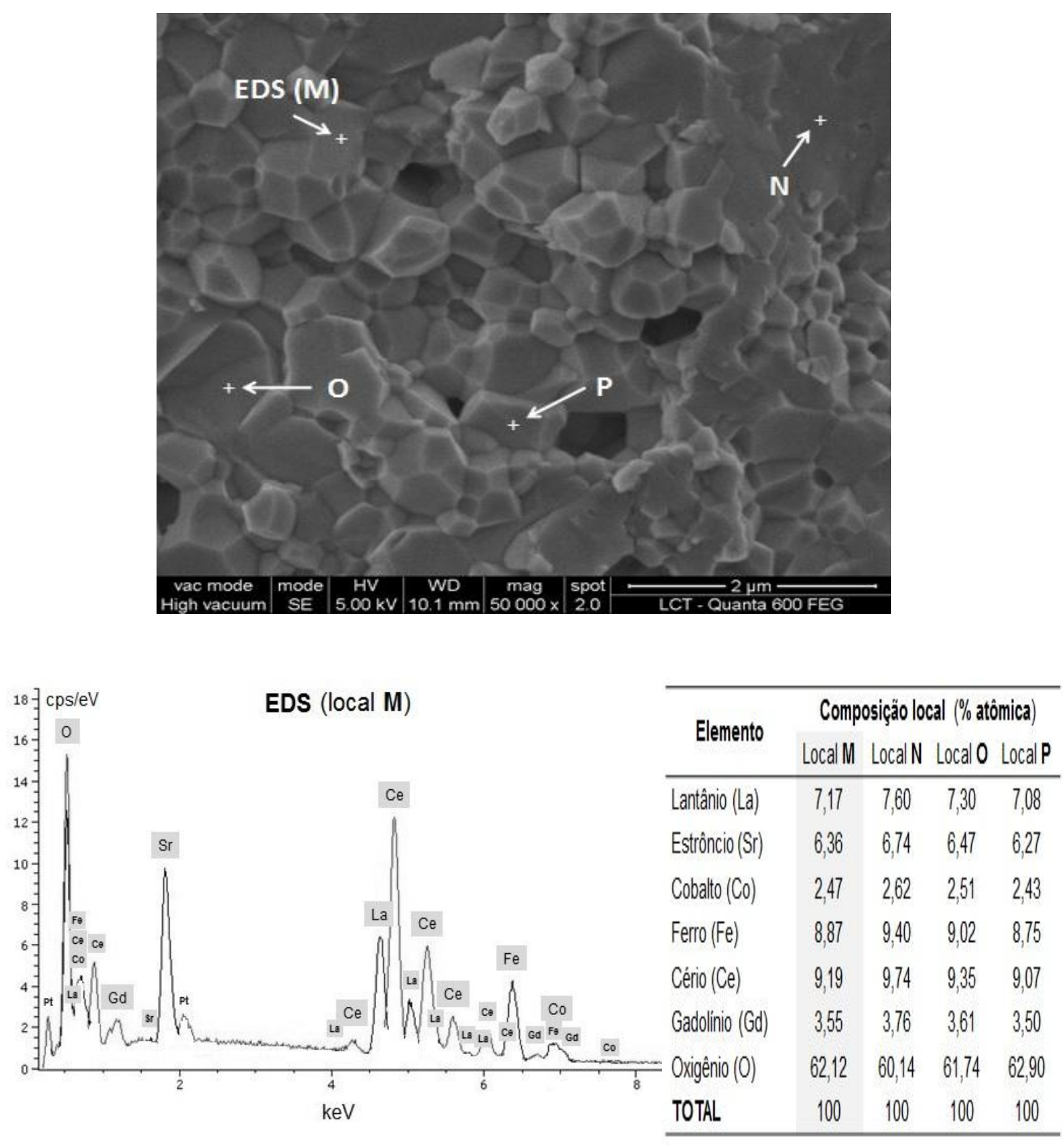

Figura 5.21 - Micrografia da cerâmica de LSCFCGO1112 com identificação quantitativa dos elementos químicos e composições atômicas por EDS. 
Comparando os resultados da amostra de LSCFCG01112, com relação a identificação quantitativa dos elementos químicos, verificou-se que as proporções entre cada elemento não variaram significativamente. Nos pontos demarcados da Figura 5.21, determinou-se que o lantânio varia 0,52\% (em \% atômica), o estrôncio $0,47 \%$, o cobalto $0,19 \%$, o ferro $0,65 \%$, o cério $0,67 \%$, o gadolínio $0,26 \%$ e o oxigênio $2,76 \%$.
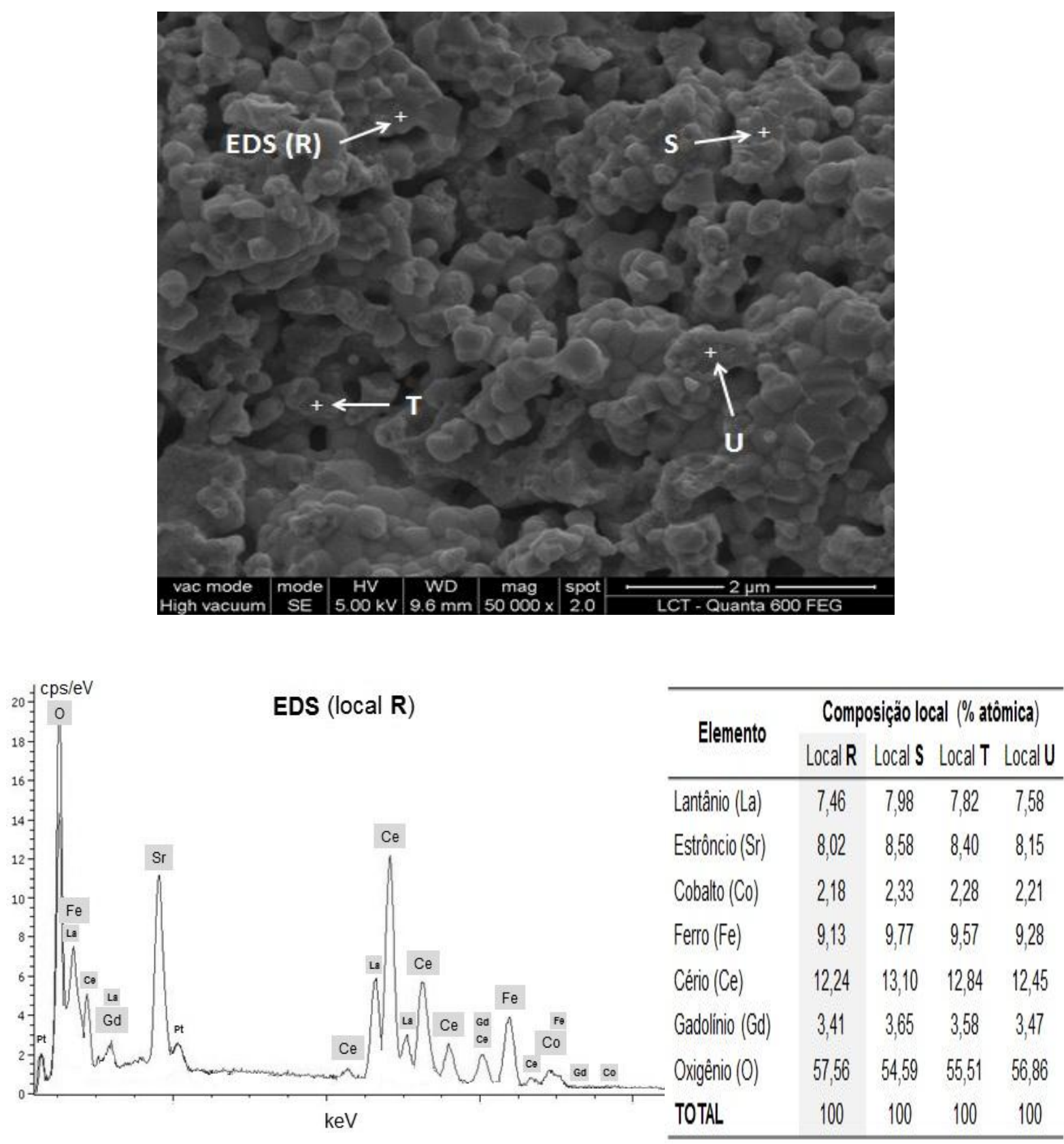

Figura 5.22 - Micrografia da cerâmica de LSCFCG01311 com identificação quantitativa dos elementos químicos e composições atômicas por EDS. 
Em seguida, analisando a micrografia da superfície fraturada, referente a amostra LSCFCGO1311 (Figura 5.22), verifica-se a presença de porosidade por toda a região observada. Essa porosidade indicou uma sinterização também em estágio inicial, confirmando que a maior parte se classifica como porosidade aberta, ou seja, poros interconectados até a superfície de fratura.
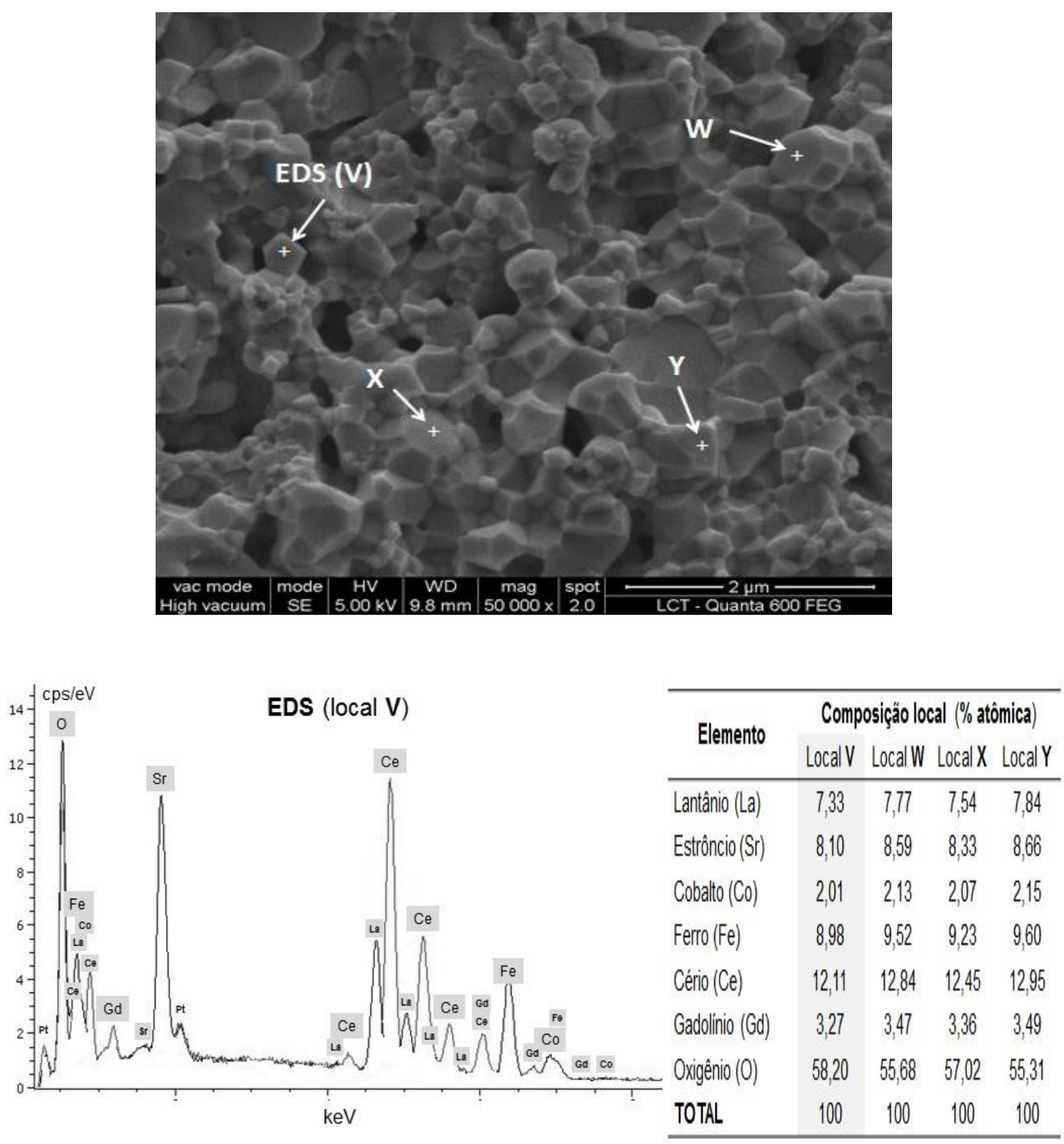

Figura 5.23 - Micrografia da cerâmica de LSCFCG01312 com identificação quantitativa dos elementos químicos e composições atômicas por EDS. 
Em todos os pontos da Figura 5.23, determinou-se que o lantânio varia 0,51\%, o estrôncio 0,56\%, o cobalto $0,14 \%$, o ferro $0,62 \%$, o cério $0,84 \%$, o gadolínio $0,22 \%$ e o oxigênio $2,89 \%$. Em todos os casos analisados, as percentagens são expressas em \% atômica.

Finalmente, realizou-se a análise para as cerâmicas dos corpos cerâmicos constituídos somente de CGO (Figuras 5.24 e 5.25) ou YSZ (Figura 5.26). Como estas amostras necessitam ser densas, as condições de sinterizações estudadas envolvem temperaturas de 1300 e $1400^{\circ} \mathrm{C}$ para a CGO e $1500^{\circ} \mathrm{C}$ para a YSZ. Em todos os casos, o patamar de sinterização foi de 1 hora.
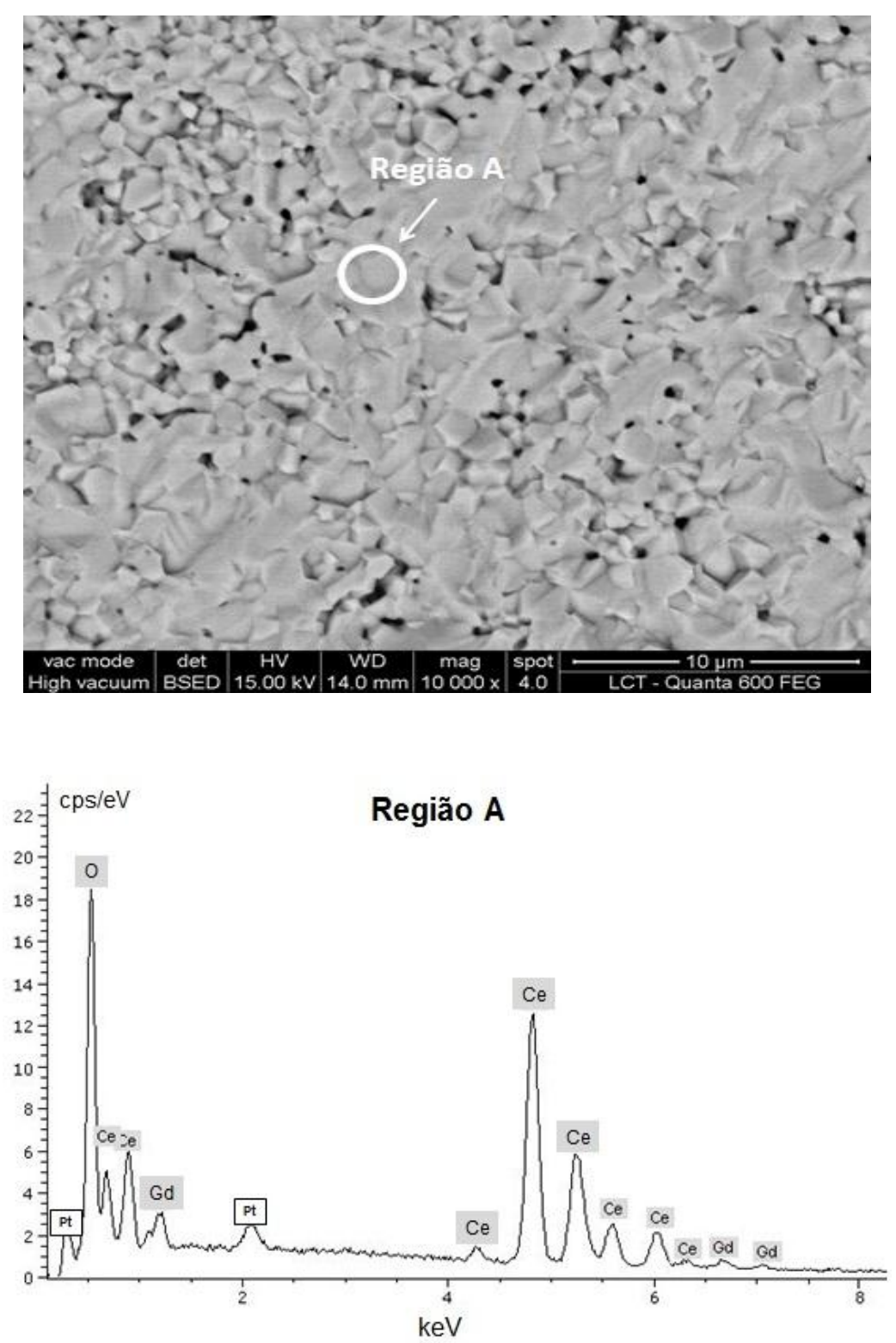

Figura 5.24 - Micrografia de CGO13 com identificação por EDS. 
Os resultados da amostra CGO13 (CGO sinterizada a $1300^{\circ} \mathrm{C}$ por 1 hora), mostraram que existe uma considerável quantidade de poros localizados por toda a região fraturada.
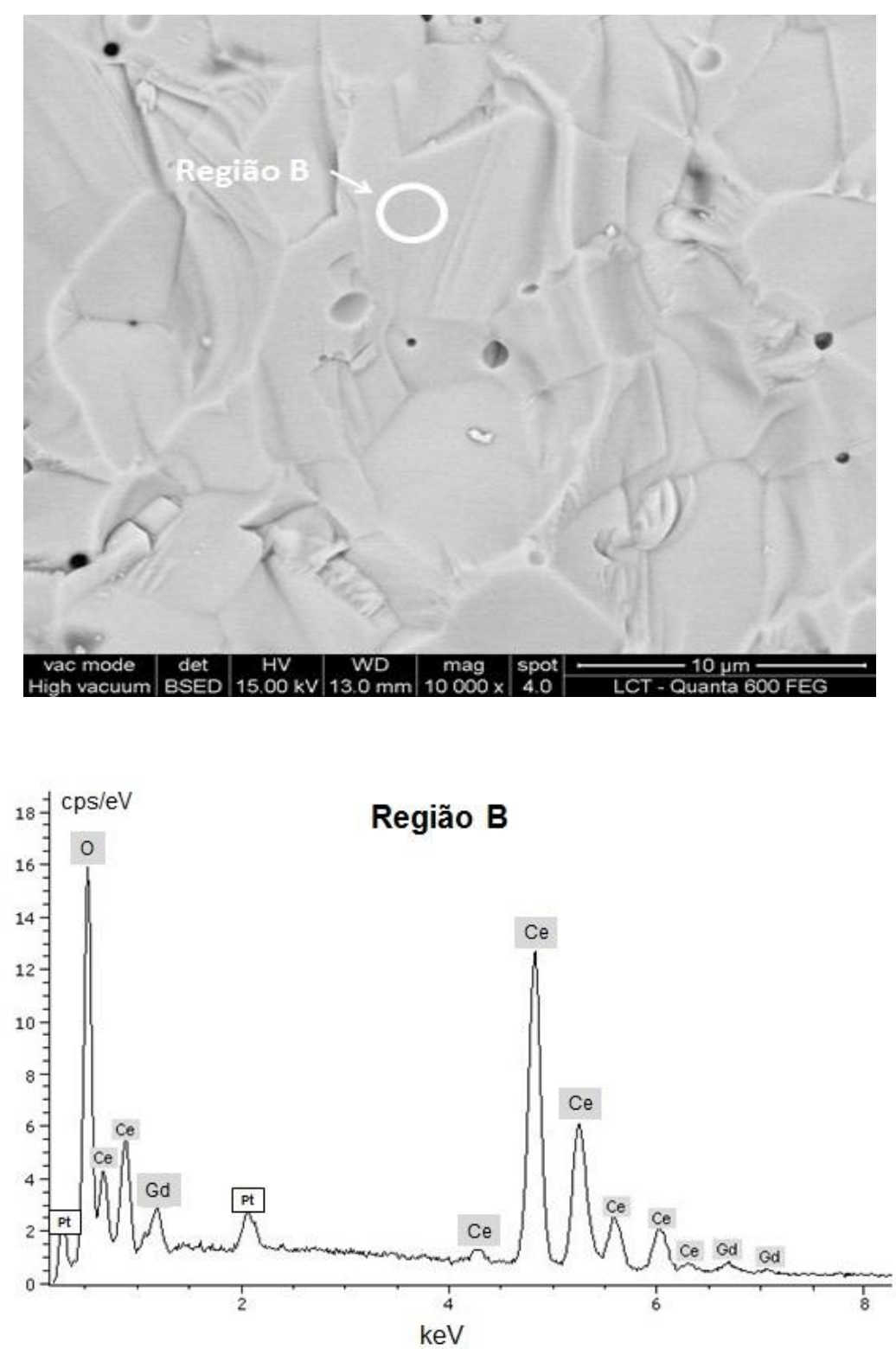

Figura 5.25 - Micrografia de CGO14 com identificação por EDS.

Comparando a cerâmica CGO14 (CGO sinterizada a 1400C por 1 hora) com a CGO13, observa-se que uma sinterização a $1400^{\circ} \mathrm{C}$ por 1 hora diminui significativamente a porosidade do material, tornando o mesmo mais denso e aplicável como componente eletrólito. 
Finalmente, realizou-se a análise para a cerâmica constituída somente de YSZ (Figura 5.26). Como esta amostra necessita ser densa, a condição de sinterização estudada envolveu a temperatura de $1500^{\circ} \mathrm{C}$ por 1 hora.
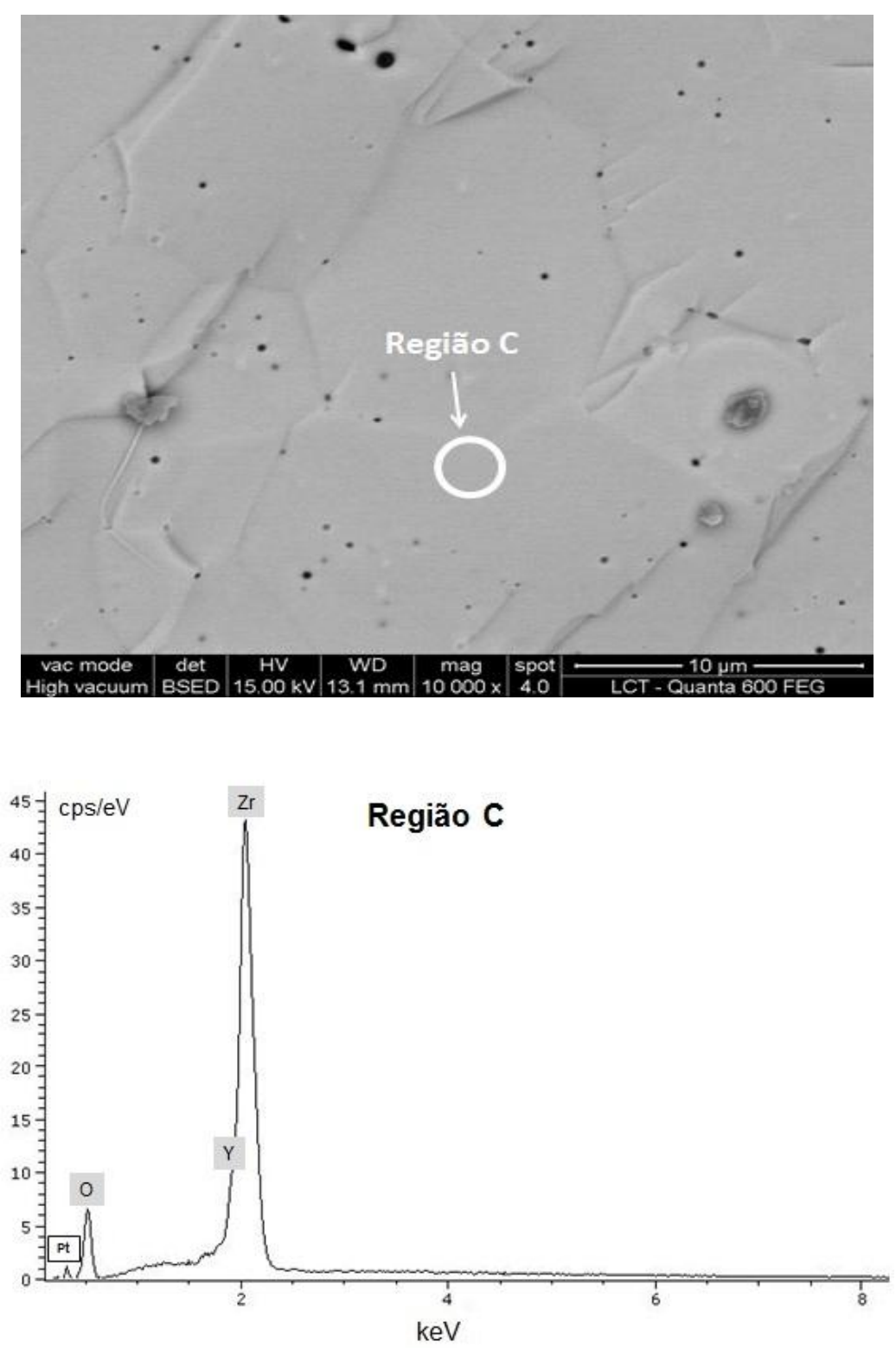

Figura 5.26 - Micrografia de YSZ com identificação por EDS.

Comparando os resultados da Figura $5.26 \mathrm{com}$ a amostra de CGO14 (Figura 5.25), determinou-se que as amostras são bastante densas, estando de acordo com os resultados de porosidade (Tabela 5.8), mas apresentam uma pequena fração de poros pequenos e arredondados para ambas as amostras. 
De acordo com os resultados encontrados e, comparando os materiais compósitos da série LSCFCGO com o LSCF, confirmou-se que as amostras sinterizadas a $1100^{\circ} \mathrm{C}$ possuem porosidade homogeneamente distribuída por toda sua superfície de fratura, sendo adequados para teste como cátodo na ITSOFC.

Os espectros de EDS apresentados nas Figuras 5.14 até 5.17 confirmam a identificação dos elementos químicos lantânio (La), estrôncio (Sr), cobalto (Co) e ferro (Fe) que constituem o óxido misto LSCF. As regiões em que foram realizadas as contagens estão demarcadas em todas as micrografias.

$\mathrm{Na}$ Figura 5.18, verifica-se a superfície de fratura do compósito LSCFCGO3111, que apresenta maior quantidade (em massa) de LSCF em relação ao CGO. Esta superfície revela a presença de bastante porosidade distribuída por toda a região analisada. O mesmo não ocorre com as Figuras 5.20 e 5.21, para LSCFCG01111 e LSCFCGO1311, respectivamente. A medida que se aumentou a quantidade de CGO, diminuiu significativamente a porosidade nas amostras sinterizadas a $1100^{\circ} \mathrm{C}$ por 1 hora. $\mathrm{O}$ mesmo ocorreu para as amostras sinterizadas a $1200^{\circ} \mathrm{C}$ por 1 hora.

As superfícies de fraturas das cerâmicas de CGO sinterizadas a $1300^{\circ} \mathrm{C}$ (Figura 5.24) e $1400^{\circ} \mathrm{C}$ (Figura 5.25) por 1 hora, além da cerâmica de YSZ, sinterizada a $1500^{\circ} \mathrm{C}$ por 1 hora (Figura 5.26), apresentaram superfícies bem densas com pouca presença de porosidade para sinterizações acima de $1300^{\circ} \mathrm{C}$. Em todos os casos foram identificados os elementos químicos constituintes nas superfícies fraturadas.

Os espectros de EDS apresentados nas Figuras 5.24 e 5.25 confirmam a identificação dos elementos químicos cério $(\mathrm{Ce})$ e gadolínio $(\mathrm{Gd})$ para as amostras de CGO e o espectro da Figura 5.26 confirma a identificação dos elementos químicos ítrio $(\mathrm{Y})$ e zircônio $(\mathrm{Zr})$ para a amostra de $\mathrm{YSZ}$. As regiões em que foram realizadas as contagens estão demarcadas nas micrografias.

De acordo com os resultados de MEV-EDS, foram selecionadas algumas amostras de LSCF, LSCFCGO, CGO e YSZ para a observação das superfícies por MEV das amostras lixadas, polidas e atacadas termicamente por 30 minutos (Figuras 5.27 a 5.32), para a revelação dos contornos de grãos.

As temperaturas de tratamento térmico foram $50^{\circ} \mathrm{C}$ inferiores com relação as respectivas temperaturas de sinterização de cada material, com a finalidade de revelar os contornos de grãos. 


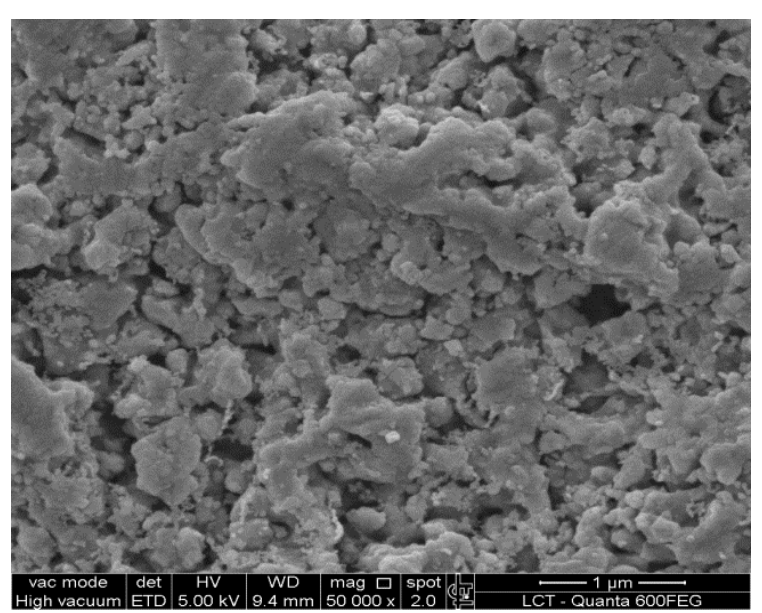

(A)

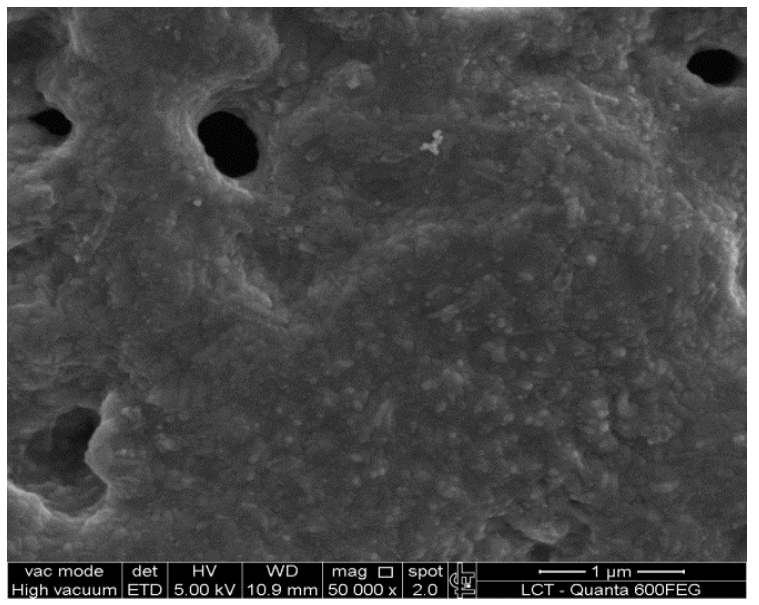

(C)

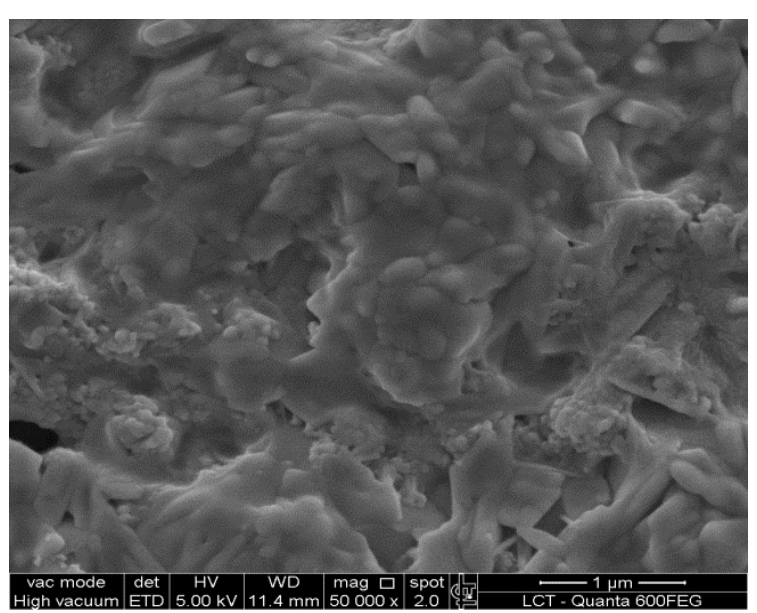

(B)

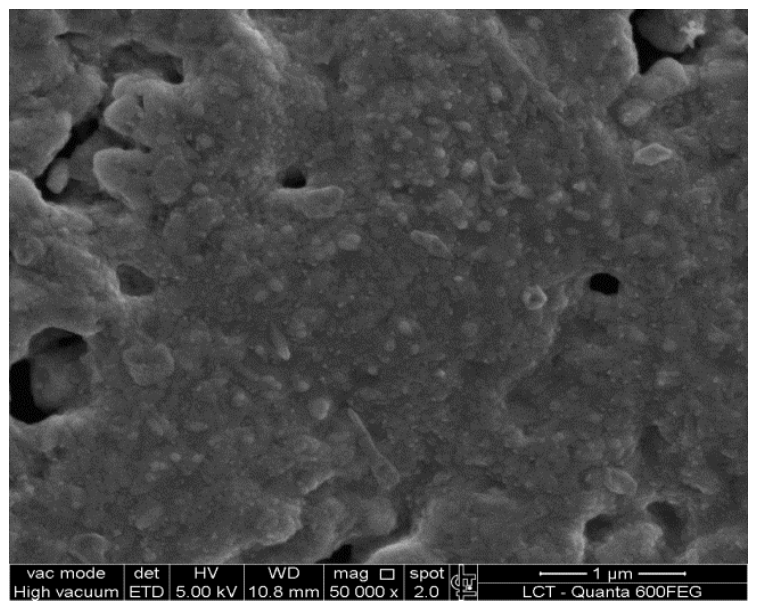

(D)

Figura 5.27 - Micrografias das superfícies fraturadas, polidas e atacadas termicamente para as amostras de LSCF sinterizadas a $900^{\circ} \mathrm{C}$ por 1 hora $(\mathbf{A})$, $1000^{\circ} \mathrm{C}$ por 1 hora $(\mathbf{B}), 1050^{\circ} \mathrm{C}$ por 1 hora $(\mathbf{C})$ e $1050^{\circ} \mathrm{C}$ por 2 horas (D).

Os resultados indicaram que, nas amostras de LSCF sinterizadas entre 900 e $1050^{\circ} \mathrm{C}$ por uma hora e sinterizada a $1050^{\circ} \mathrm{C}$ por duas horas, os grãos aparecem discretamente e, consequentemente, os grãos e contornos de grãos não foram revelados. As micrografias revelam que nas amostras de LSCF sinterizadas nestas condições há nítida presença de poros.

Como a microestrutura não se definiu durante a sinterização a $900^{\circ} \mathrm{C}$ por 1 hora (A), que se refere a amostra atacada termicamente a $850^{\circ} \mathrm{C}$ por 30 minutos, não ocorre a revelação dos contornos de grão do material, apresentando somente uma alta quantidade de poros espalhados por toda a superfície.

O LSCF sinterizado entre 900 e $1050^{\circ} \mathrm{C}$ não revelou seus grãos após as etapas de lixamento, polimento e ataque térmico. 


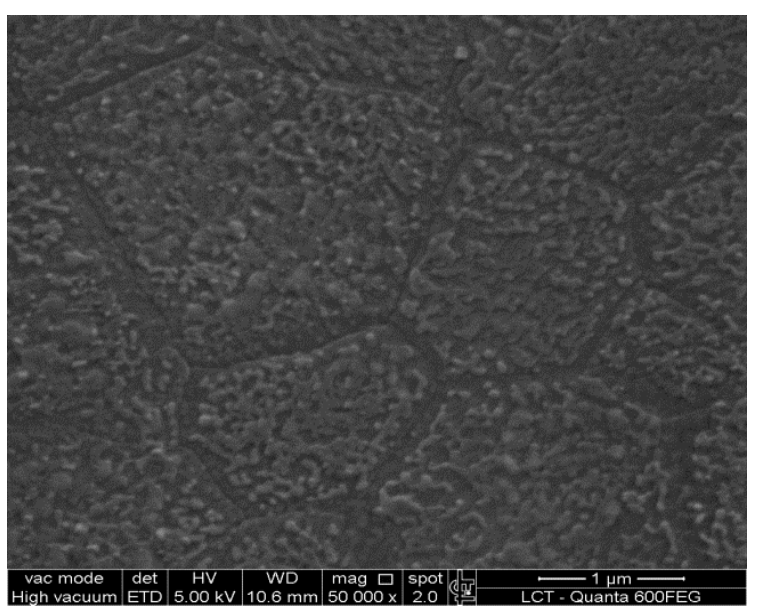

(E)

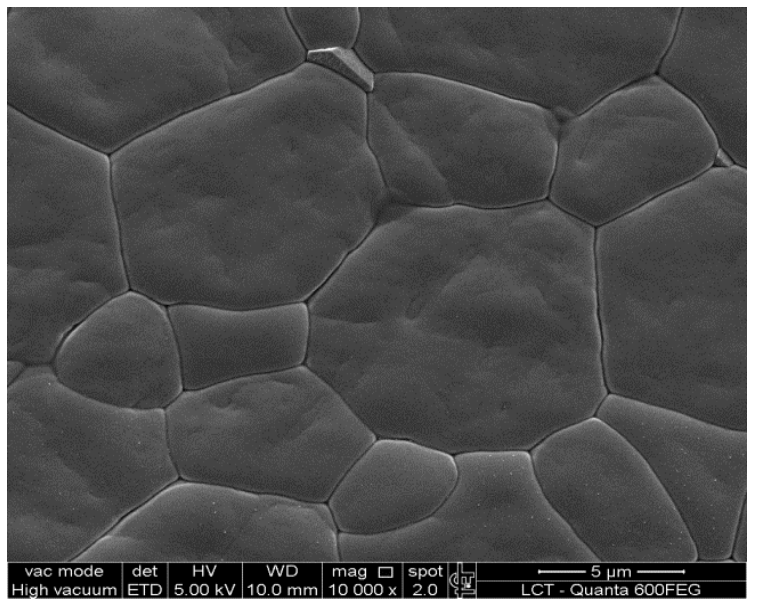

(G)

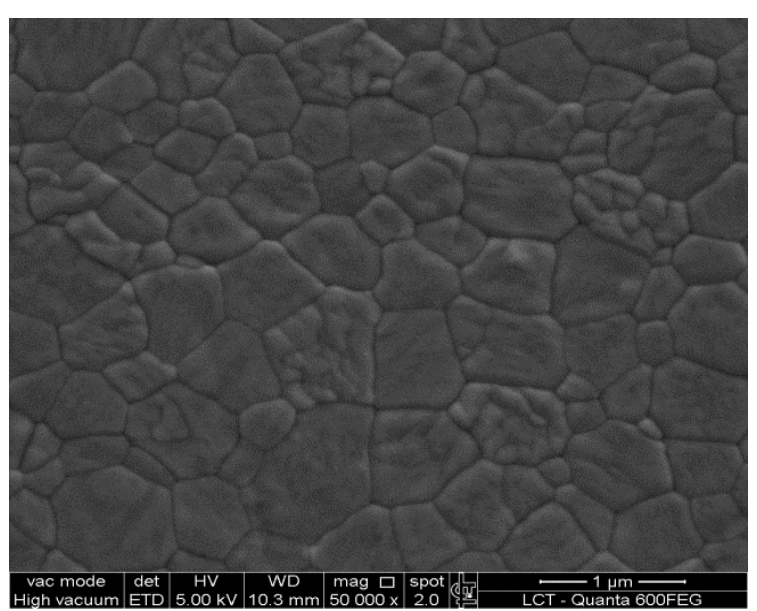

(F)

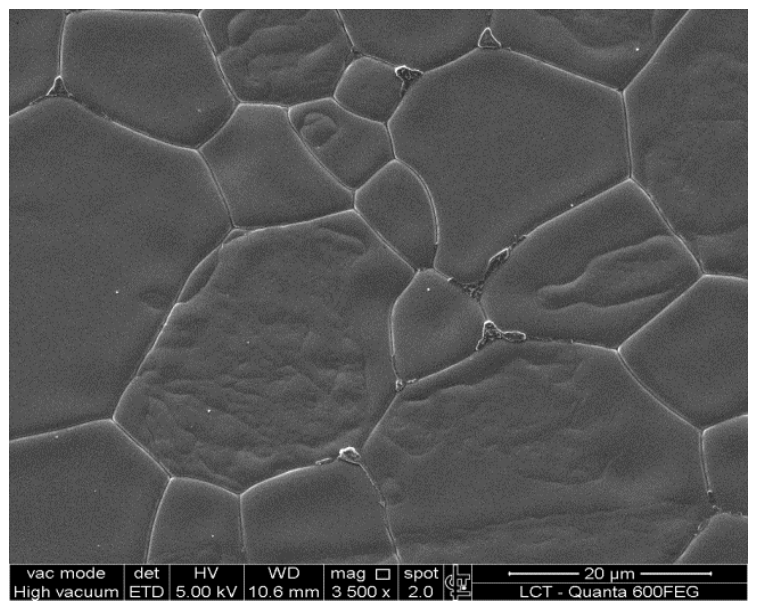

(H)

Figura 5.28 - Micrografias das superfícies fraturadas, polidas e atacadas termicamente para as amostras de LSCF sinterizadas a $1100^{\circ} \mathrm{C}$ por 1 hora $(\mathbf{E})$, $1200^{\circ} \mathrm{C}$ por 1 hora $(\mathbf{F}), 1300^{\circ} \mathrm{C}$ por 1 hora $(\mathbf{G})$ e $1400^{\circ} \mathrm{C}$ por 1 hora $(\mathbf{H})$.

As micrografias da Figura 5.28 confirmam o aparecimento de contornos de grãos nas amostras de LSCF, sinterizadas entre 1200 e $1400^{\circ} \mathrm{C}$ por 1 hora.

As micrografias comprovam que as amostras de LSCF sinterizadas nestas condições apresentaram baixa quantidade de poros, em decorrência da sinterização. Com base nestes resultados, pode-se verificar que para o material exercer a função de cátodo de uma ITSOFC, é necessária uma sinterização de aproximadamente $1100^{\circ} \mathrm{C}$ por 1 hora, pois nessa temperatura, existe a presença de porosidade associada a microestrutura contendo grãos e contornos de grãos.

Tais resultados demonstram que as amostra sinterizada a $1100^{\circ} \mathrm{C}$ possui uma microestrutura ainda em formação (Figura 5.28) e com presença de porosidade em toda sua superfície (Figura 5.14). 
Entretanto, a amostra apresenta vestígios do início da formação de grãos e contornos de grãos, indicando que terá densidade e crescimento dos grãos em sinterizações acima de $1100^{\circ} \mathrm{C}$, como é comprovado pelas demais micrografias (F, G e H) das amostras sinterizadas entre 1200 e $1400^{\circ} \mathrm{C}$.

As amostras de CGO lixadas, polidas e atacadas termicamente por 30 minutos (Figuras 5.29 e 5.30) são apresentadas em seguida.

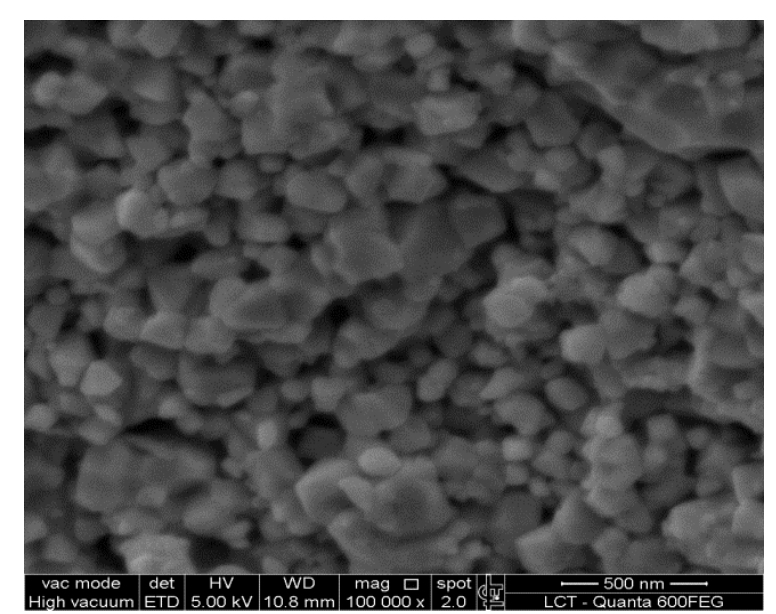

(A)

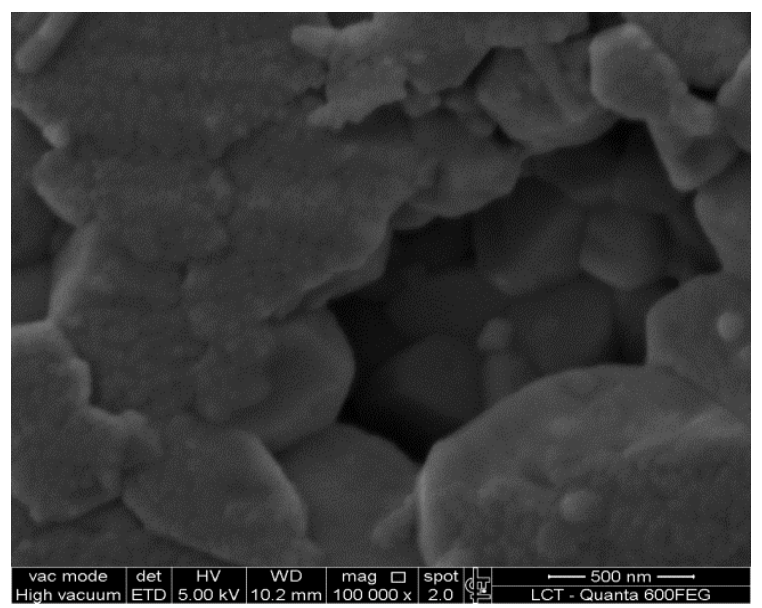

(C)

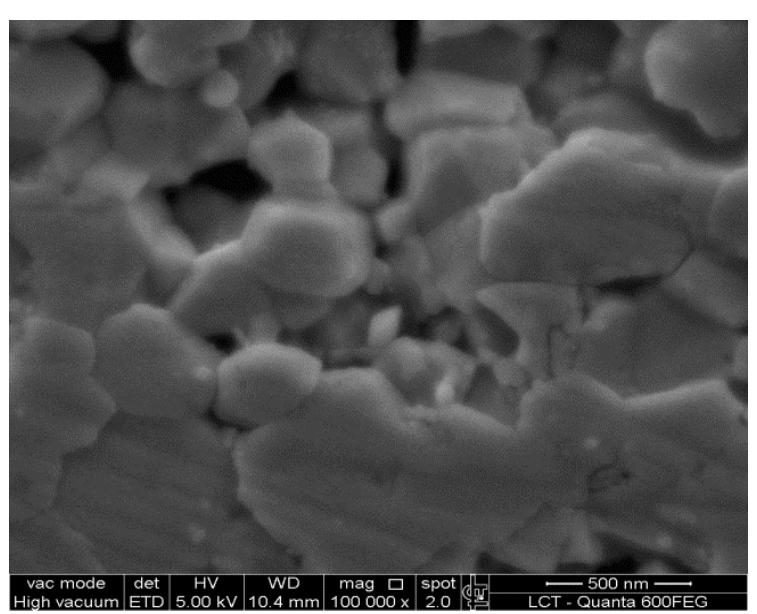

(B)

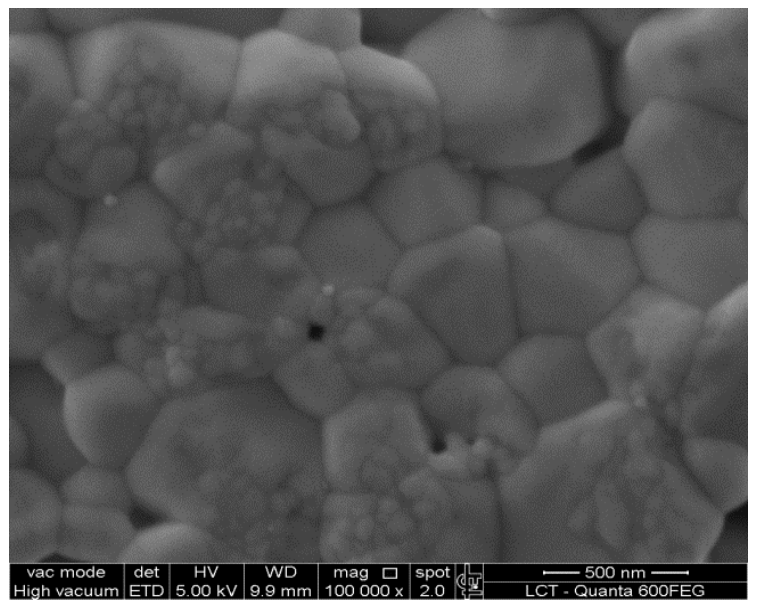

(D)

Figura 5.29 - Micrografias das superfícies fraturadas, polidas e atacadas termicamente para as amostras de CGO sinterizadas a $1000^{\circ} \mathrm{C}$ por 1 hora $(\mathbf{A})$, $1100^{\circ} \mathrm{C}$ por 1 hora $(\mathbf{B}), 1200^{\circ} \mathrm{C}$ por 1 hora $(\mathbf{C})$ e $1250^{\circ} \mathrm{C}$ por 1 hora (D).

Os resultados indicaram que nas amostras de CGO sinterizadas até $1250^{\circ} \mathrm{C}$, existe presença porosidade acentuada, não sendo adequadas para a função de eletrólito sólido das ITSOFCs. 


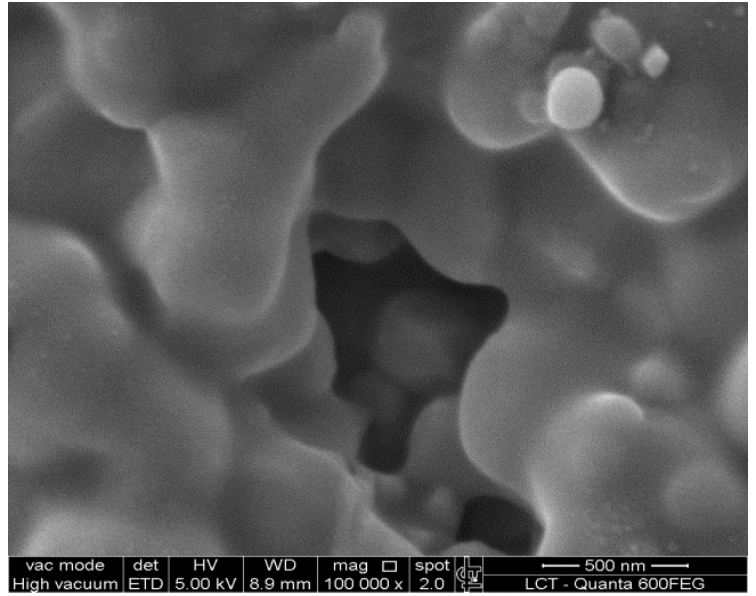

(E)

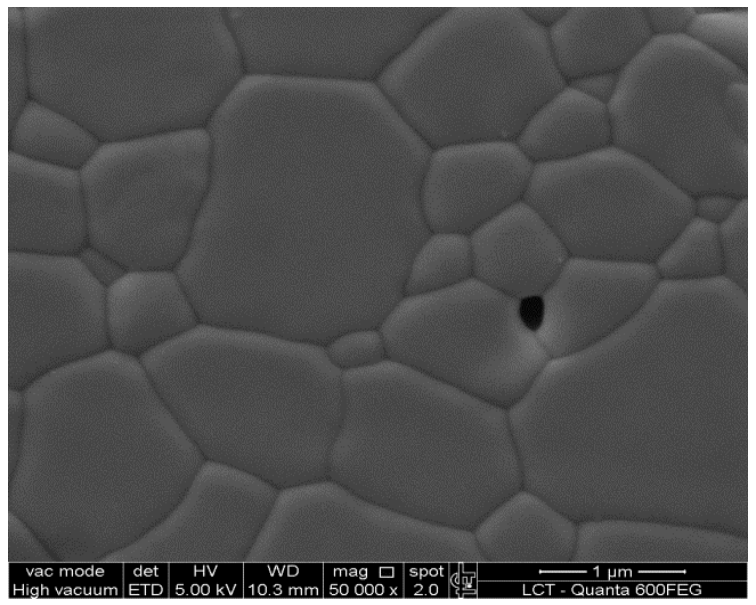

(G)

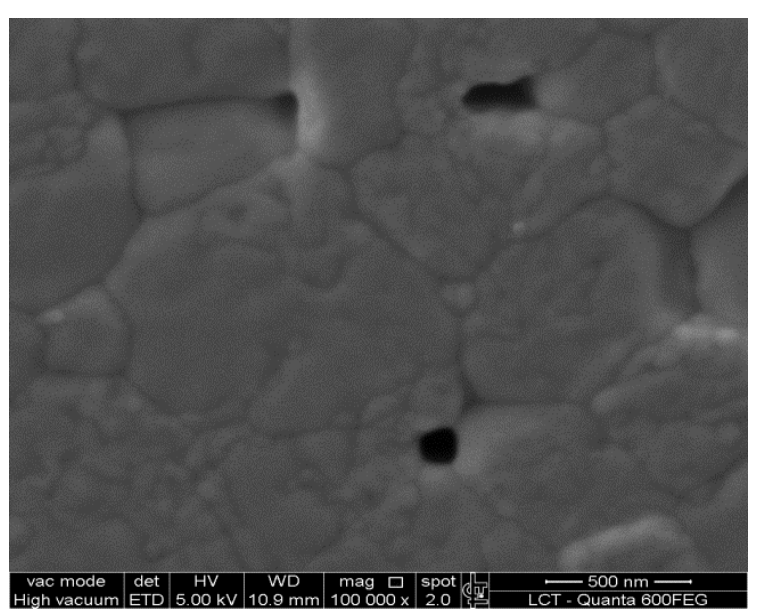

(F)

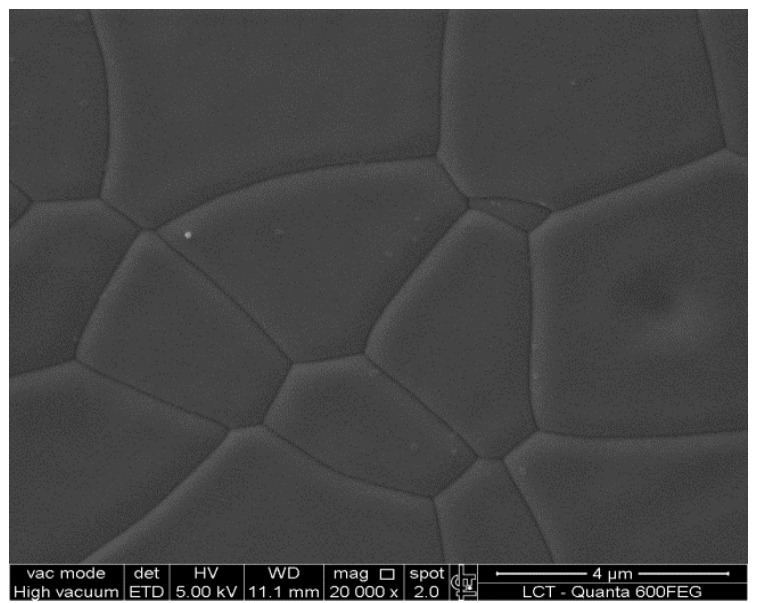

(H)

Figura 5.30 - Micrografias das superfícies fraturadas, polidas e atacadas termicamente para as amostras de CGO sinterizadas a $1250^{\circ} \mathrm{C}$ por 2 horas (E), $1300^{\circ} \mathrm{C}$ por 1 hora $(\mathbf{F}), 1400^{\circ} \mathrm{C}$ por 1 hora $(\mathbf{G})$ e $1500^{\circ} \mathrm{C}$ por 1 hora $(\mathbf{H})$.

Os resultados indicam que nas amostras de CGO sinterizadas entre 1400 e $1500^{\circ} \mathrm{C}$, os grãos aparecem claramente e, consequentemente, a sua microestrutura está totalmente bem definida.

As micrografias indicam que, as amostras de CGO sinterizadas nestas condições, apresentam baixa quantidade de poros e grãos bem definidos, para as cerâmicas sinterizadas a 1400 e $1500^{\circ} \mathrm{C}$.

Com base nestes resultados, confirmou-se que para o material exercer a função de eletrólito, é necessária uma sinterização de pelo menos $1400^{\circ} \mathrm{C}$.

Em seguida são reveladas as micrografias (Figura 5.31) das amostras lixadas, polidas e atacadas termicamente dos compósitos de LSCFCGO (LSCFCGO31, LSCFCG011 e LSCFCGO13) sinterizados entre 1100 e 1200ㄷ. 


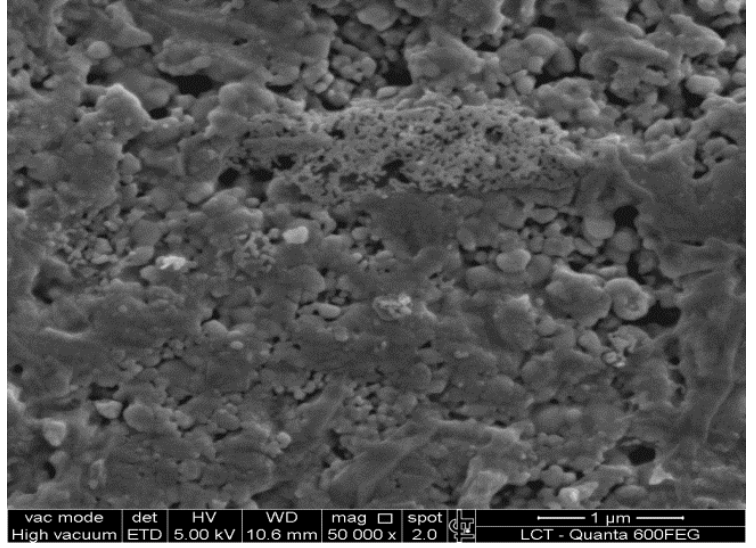

(A)

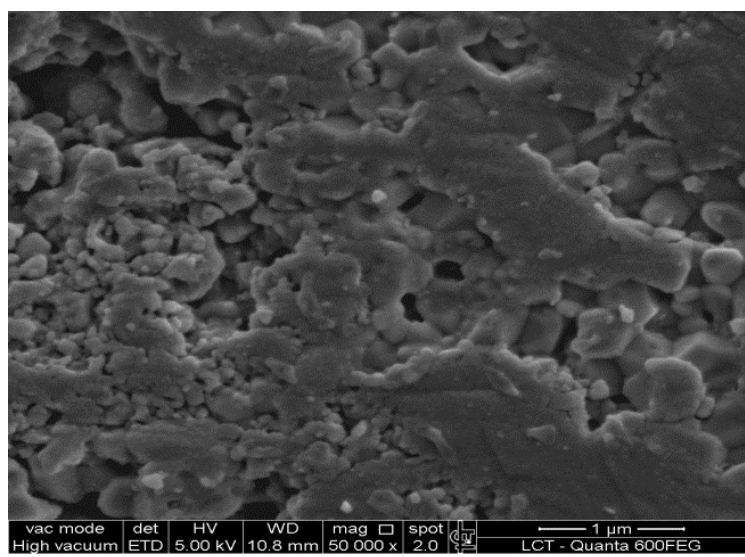

(C)

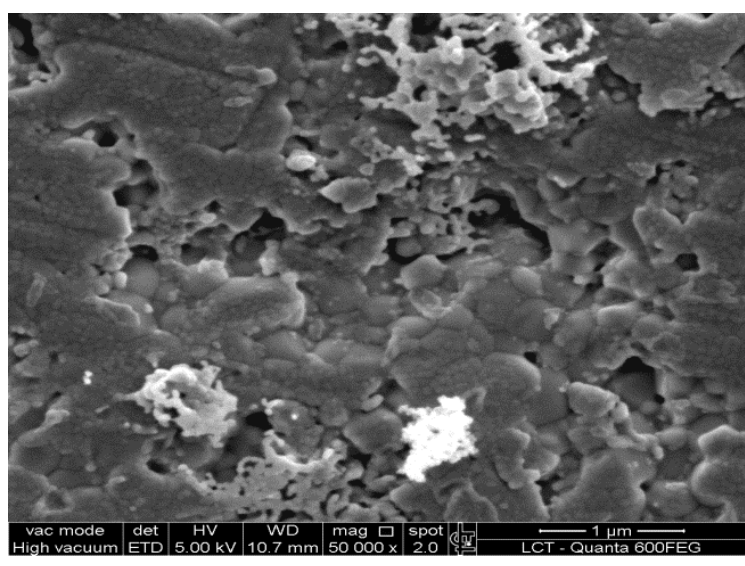

(E)

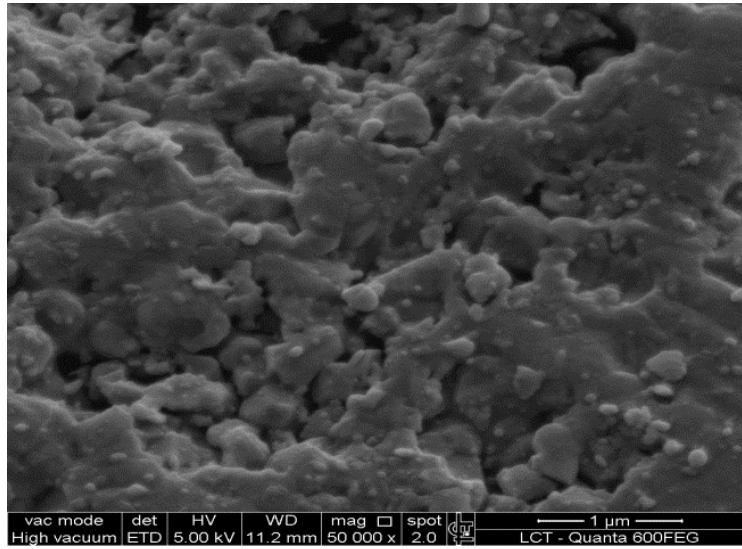

(B)

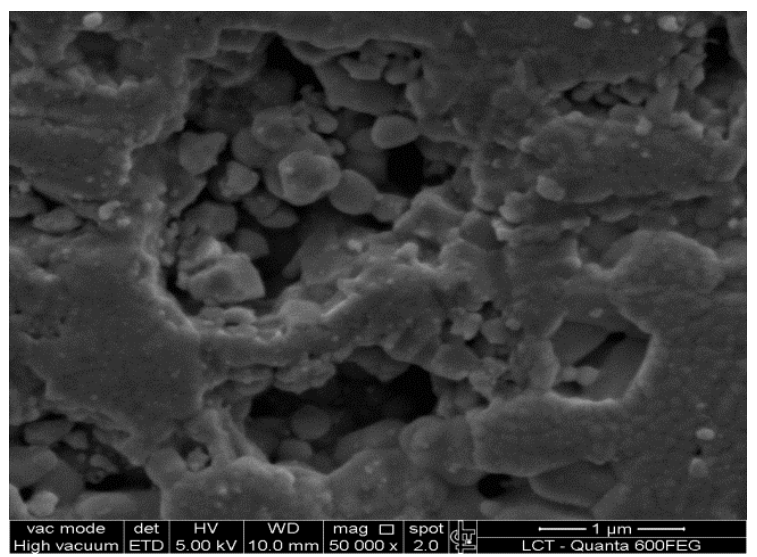

(D)

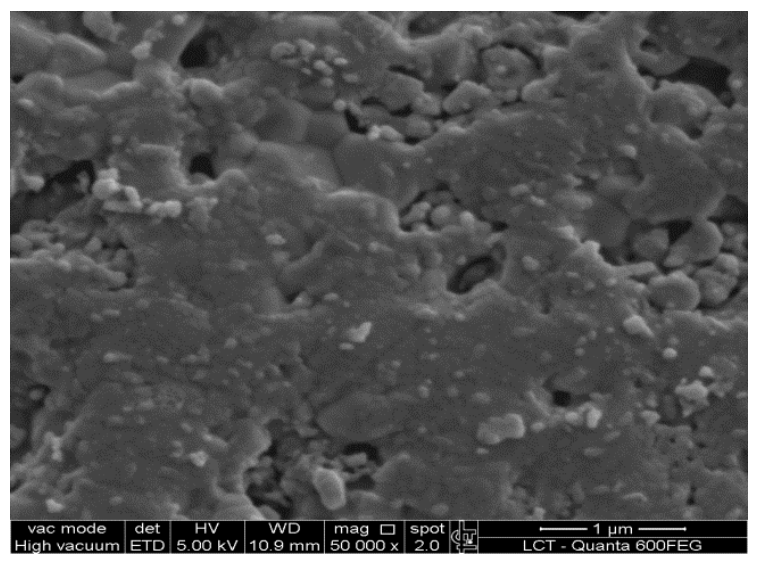

(F)

Figura 5.31 - Micrografias das superfícies fraturadas, polidas e atacadas termicamente para as amostras de LSCFCGO31 (A e B), LSCFCGO11 (C e D) e LSCFCGO13 (E e F), sinterizadas a $1100^{\circ} \mathrm{C}$ por 1 hora $(\mathbf{A}, \mathbf{C}$ e $\mathbf{E})$ e a $1200^{\circ} \mathrm{C}$ por 1 hora (B, D e F).

Os resultados indicam que as amostras LSCFCGO sinterizadas a 1100 ou $1200^{\circ} \mathrm{C}$ são adequadas como cátodo compósito contendo porosidade significativa e distribuída em toda sua superfície. 
Entretanto, como os melhores resultados de porosidade e micrografia para as amostras de LSCF foram obtidos com sinterização a $1100^{\circ} \mathrm{C}$ por 1 hora, foram definidos os compósitos da série LSCFCGO que possuem a mesma temperatura de sinterização do LSCF.

Esta padronização foi importante para a deposição das diferentes camadas de LSCFCGO e LSCF sobre os substratos de CGO ou YSZ, pois a mesma temperatura de sinterização resultou em uma microestrutura parecida entre o cátodo compósito e o cátodo, além de uma distribuição de porosidade mais homogênea e formação de uma maior TBP.

Com o objetivo de evitar problemas de aderência entre os filmes finos, os substratos foram lixados, com a finalidade formar uma superfície com ranhuras, facilitando a aderência dos compósitos LSCFCGO sobre o a CGO.

O mesmo procedimento foi realizado para a deposição de camadas micrométricas no substrato e YSZ. A única diferença é que, neste caso, foi depositada primeiro uma camada de CGO sobre YSZ, para depois, depositar as camadas de LSCFCGO e LSCF.

Por fim, foram reveladas as micrografias (Figura 5.32) das amostras lixadas, polidas e atacadas termicamente das cerâmicas de YSZ sinterizadas entre 1200 e $1500^{\circ} \mathrm{C}$.

Os resultados indicaram que nas amostras de YSZ sinterizadas entre 1400 e $1500^{\circ} \mathrm{C}$, os grãos e contornos de grãos aparecem mais claramente e, consequentemente, a sua densificação está desenvolvida.

As micrografias também indicaram que as amostras de YSZ sinterizadas nestas condições apresentam baixa quantidade de poros. Com base nestes resultados, confirmou-se que para o material exercer a função de eletrólito de uma ITSOFC, foi necessária uma sinterização de pelo menos $1400^{\circ} \mathrm{C}$.

Tais resultados demonstram que as amostras sinterizadas entre $1400 \mathrm{e}$ $1500^{\circ} \mathrm{C}$ possuem os melhores resultados, sendo que a distribuição dos contornos de grãos está distribuída de uma forma menos homogênea para ambas as amostras que possuem sua densificação em desenvolvimento. Em decorrência disso e devido ao processo de sinterização do material, que ocorre em temperaturas elevadas e também ao ataque térmico (choque térmico), ocasionando crescimento de grãos. 


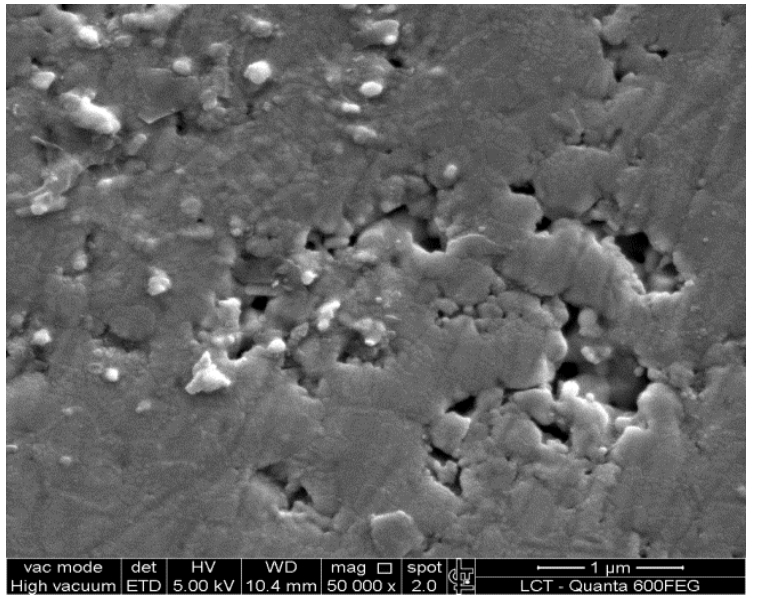

(A)

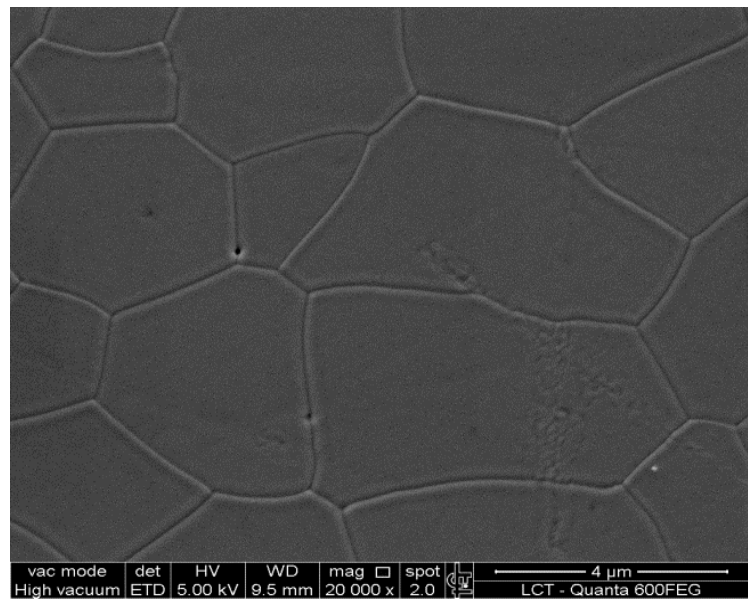

(C)

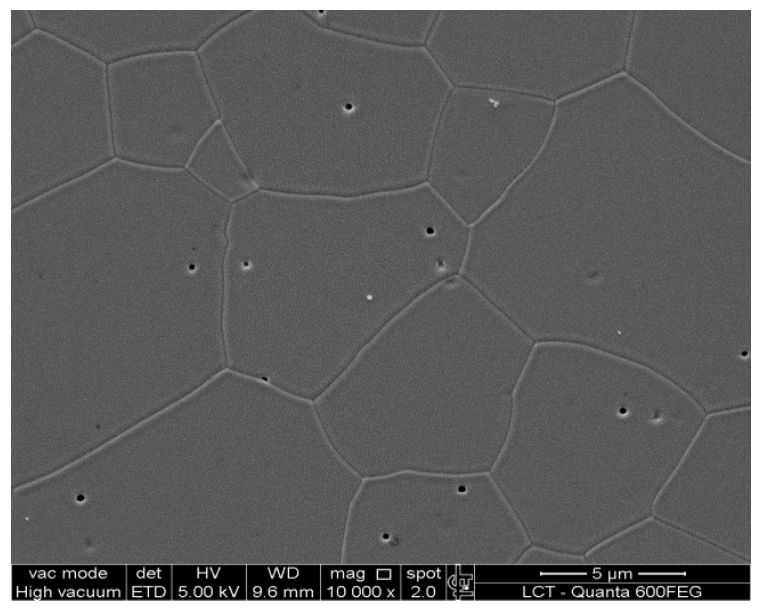

(E)

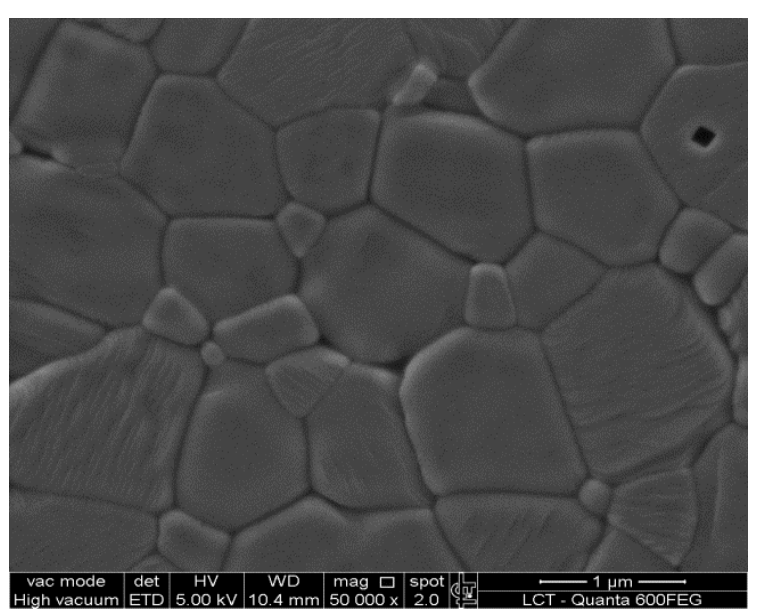

(B)

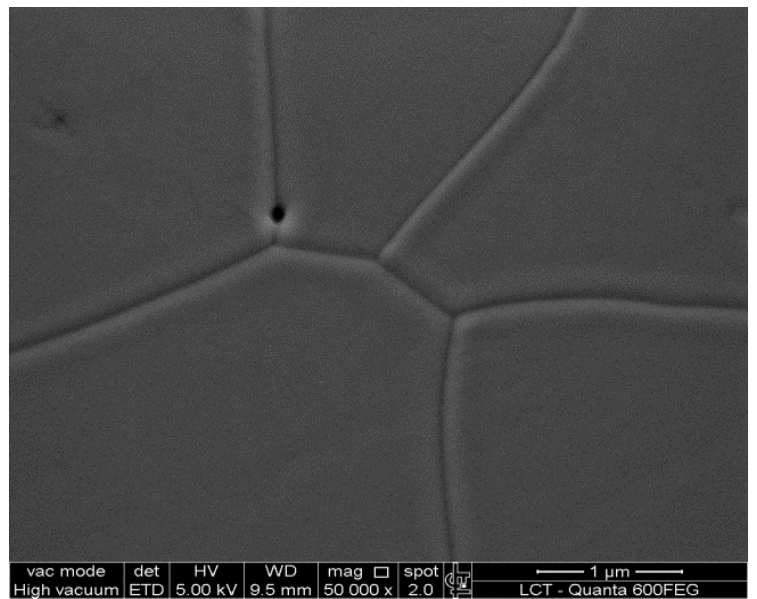

(D)

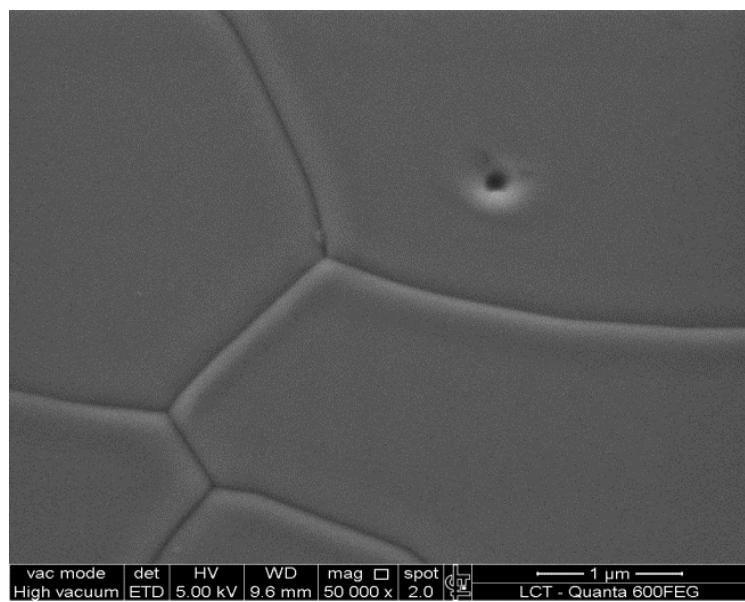

(F)

Figura 5.32 - Micrografias das superfícies fraturadas, polidas e atacadas termicamente para as amostras de YSZ sinterizadas a $1200^{\circ} \mathrm{C}$ por 1 hora $(\mathbf{A})$, $1300^{\circ} \mathrm{C}$ por 1 hora $(\mathbf{B}), 1400^{\circ} \mathrm{C}$ por 1 hora $(\mathbf{C}$ e $\mathbf{D})$ e $1500^{\circ} \mathrm{C}$ por 1 hora $(\mathbf{E}$ e $\mathbf{F})$. 
No início dos ataques térmicos, foram realizados ataques térmicos de 20 minutos nas mesmas condições; entretanto, os resultados não foram satisfatórios, pois os grãos e contornos de grãos não foram revelados nas imagens para a grande maioria das amostras.

Apesar da heterogeneidade quanto ao tamanho dos grãos, foi possível mensurar de uma forma razoável, o tamanho estimado dos grãos das amostras sinterizadas. Observou-se que o tamanho médio dos grãos para as amostras de LSCF sinterizada a $1100^{\circ} \mathrm{C}$ está entre 0,5 e $2 \mu \mathrm{m}$. De acordo com a literatura, o tamanho de grão influencia de forma significativa nos resultados de condutividade elétrica, sendo que para conseguir resultados considerados adequados para a aplicação como cátodo de uma ITSOFC, os tamanhos médios de grãos devem ser inferiores a aproximadamente $5 \mu \mathrm{m}{ }^{(37)}$.

\subsection{Caracterização das suspensões cerâmicas}

Com o objetivo de obter condições de dispersões adequadas e obter suspensões estáveis de LSCF, LSCFCGO e CGO, verificou-se o comportamento superficial dos particulados de LSCF e CGO e sua mobilidade eletroforética por medidas de análise de Potencial Zeta em função do potencial de hidrogênio iônico, conhecido como pH (Figura 5.33). Uma combinação dos mecanismos eletrostáticos e estéricos (denominado de estabilização eletroestérica) foram utilizados para a estabilização.

O procedimento consiste em adicionar álcool etílico aos particulados de LSCF ou CGO, numa razão de cinco partes de álcool para uma parte de LSCF, em um béquer, seguido de homogeneização da suspensão utilizando um agitador mecânico. Todas as suspensões foram homogeneizadas utilizando ultrassom seguido de dispersão em agitador mecânico por aproximadamente 30 segundos.

De acordo com a Figura 5.33, os pontos isoelétricos dos particulados de CGO e LSCF possuem um pH de, respectivamente, 6,50 e 10,20. Comparando-se as curvas, confirma-se que a única região possível, para associar esses dois materiais em uma única suspensão, garantindo que ambos estejam dispersos, é em um valor de $\mathrm{pH}$ abaixo de 5,80. Isso ocorre pois ambos apresentam valores de potencial superiores a $20 \mathrm{mV}$, sendo adequados a produção de suspensões ${ }^{(84)}$. 


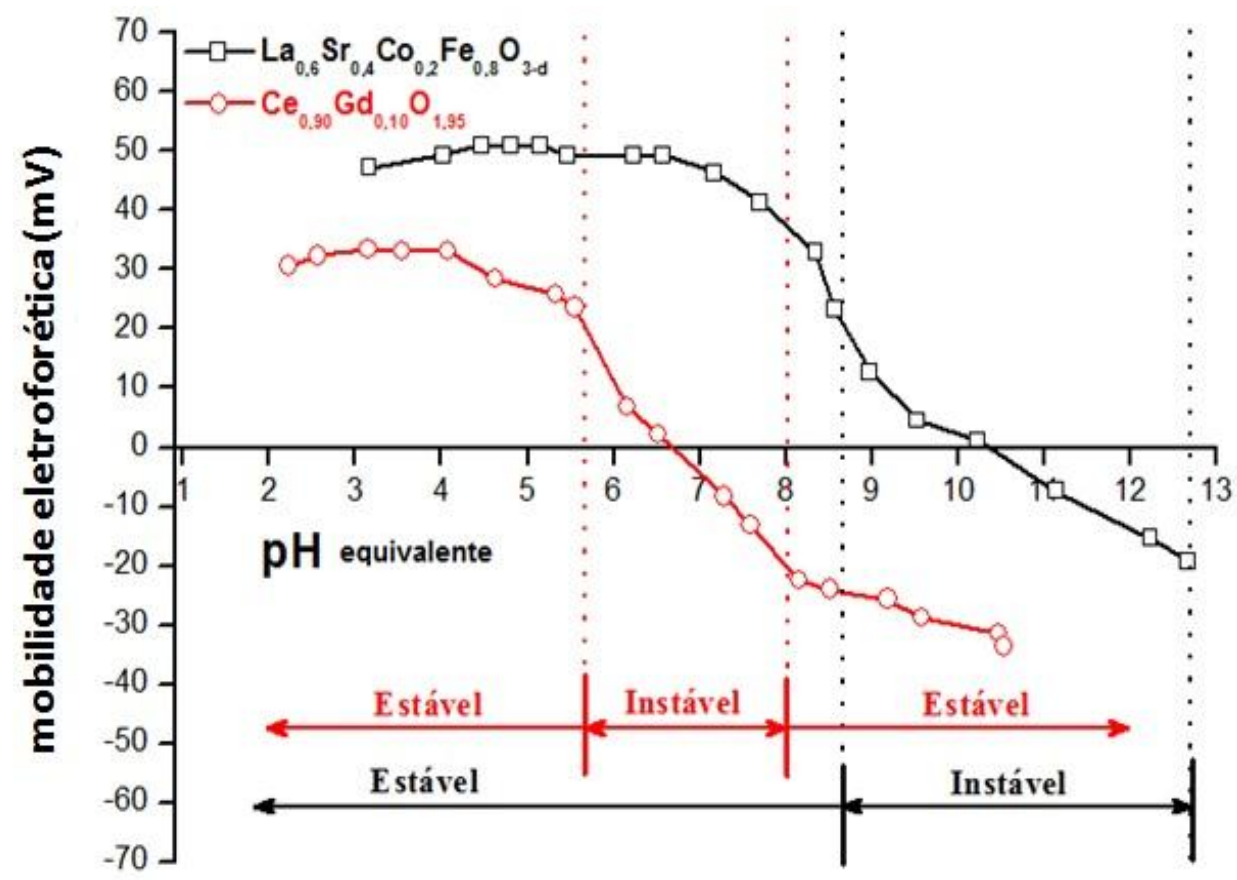

Figura 5.33 - Mobilidade eletroforética das dispersões de LSCF e CGO.

Em valores de $\mathrm{pH}$ superiores a 5,80 existe a possibilidade de ocorrer a interação ou mesmo a decantação destes materiais, uma vez que estão na região de instabilidade (valores de potencial inferiores a $20 \mathrm{mV}$ ) entre os dois, ou mesmo, na região onde eles apresentam valores opostos de carga.

A carga superficial mais elevada para a partícula de LSCF em álcool etílico foi de aproximadamente $50 \mathrm{mV}$ em um intervalo de $\mathrm{pH}$ equivalente $(\mathrm{pH}$ mensurado em solução alcoólica) entre 4 e 6 . Para o de CGO, a carga superficial está em torno de $35 \mathrm{mV}$ em um intervalo de $\mathrm{pH}$ equivalente entre 3 e 5.

Os dois materiais possuem uma carga de superfície em suas partículas com características muito semelhantes. O comportamento desses materiais apresenta alto potencial na superfície de suas partículas em meio ácido, o que facilita a preparação e estabilização de dispersões dos compósitos LSCFCGO em um intervalo entre $\mathrm{pH}$ equivalente abaixo de 5,80 na presença de álcool etílico.

O dispersante foi escolhido de acordo com a literatura técnica ${ }^{37 ; 101)}$ para este tipo de processo de conformação envolvendo suspensões orgânicas. A quantidade considerada adequada, em porcentagem em massa, referente ao dispersante polietilenoimina (PEI), foi determinada pela técnica de decantação, variando a concentração entre 1 e $5 \%$ (em massa), com relação à quantidade total de particulados presentes na suspensão. 
O experimento foi inicialmente realizado nas suspensões de LSCF e posteriormente na série LSCFCGO e CGO. As suspensões contendo diferentes concentrações de PEI foram mantidas em repouso por um período de até 24 horas em $\mathrm{pH}$ igual a 5 . Uma estabilidade entre 6 e 8 horas foi suficiente para a deposição dos filmes micrométricos no substrato, pois as etapas de deposições de cada camada não excederam 2 horas. Com essas condições e fixando 0 tempo de decantação, definiu-se que a seleção da suspensão que possuiu a concentração de PEI mais adequada foi função da amostra que apresentou maior estabilidade entre suas partículas dispersas no meio orgânico (álcool etílico).

Com o resultado do teste inicial para os particulados de LSCF, verificou-se que a presença do dispersante PEI não foi perceptível ao olho humano como está de acordo com o experimento por decantação (Figura 5.34). As suspensões que foram observadas por 6, 12 e 24 horas apresentaram praticamente o mesmo comportamento com ou sem a presença de $1 \%$ de PEI, pois a maioria dos particulados se mantiveram dispersos.

Após 6 horas

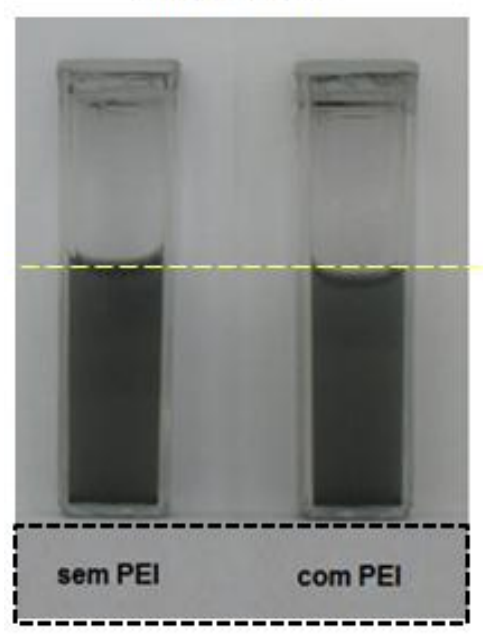

Após 12 horas

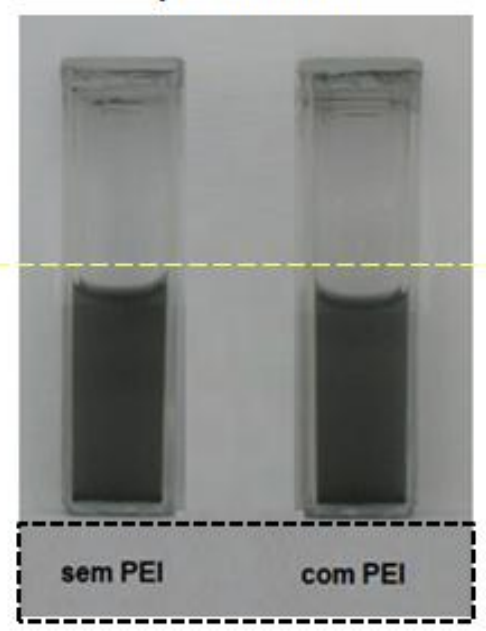

Após 24 horas

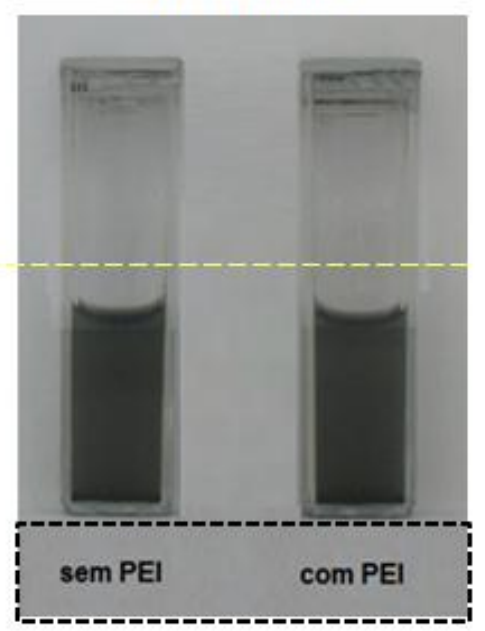

Figura 5.34 - Estabilidades das suspensões de LSCF sem e com adição de $1 \%$ de PEl em função do tempo de decantação.

Entretanto, percebeu-se que a adição de pelo menos 1\% (em massa) de PEI ocasionou um maior tempo de decantação das partículas. O resultado preliminar comprovou que o solvente, álcool etílico, e o dispersante, PEI, são estabilizaram as partículas de LSCF por um período relativamente longo (até 24 horas) e suficiente para a deposição dos filmes com uso de aerógrafo. 
Com o objetivo de minimizar os custos envolvidos na etapa de processamento, optou-se em desconsiderar adições superiores a $1 \%$ do dispersante PEI para a preparação de suspensões de LSCF.

Realizou-se o mesmo teste para os particulados de LSCFCGO e, verificou-se um comportamento similar se comparado com as suspensões de LSCF. Entretanto, a ausência do dispersante não cria condições de estabilização, mas na presença de $1 \%$ em massa de $\mathrm{PEI}$, os particulados das três suspensões (LSCFCGO31, LSCFCGO11 e LSCFCGO13) se mantiveram dispersos homogeneamente. As suspensões que foram observadas por 6, 12 e 24 horas apresentaram um comportamento similar com a presença do dispersante PEI, pois os particulados se mantiveram dispersos por até 12 horas.

Para o teste referente aos particulados de CGO (Figura 5.35), verificouse que a presença do PEI também influencia no experimento por decantação, pois as suspensões que foram observadas por até 24 horas, apresentaram um comportamento de estabilidade somente com a presença de $1 \%$ (em massa) de PEI (Figura 5.35 C), para os particulados se manterem dispersos.

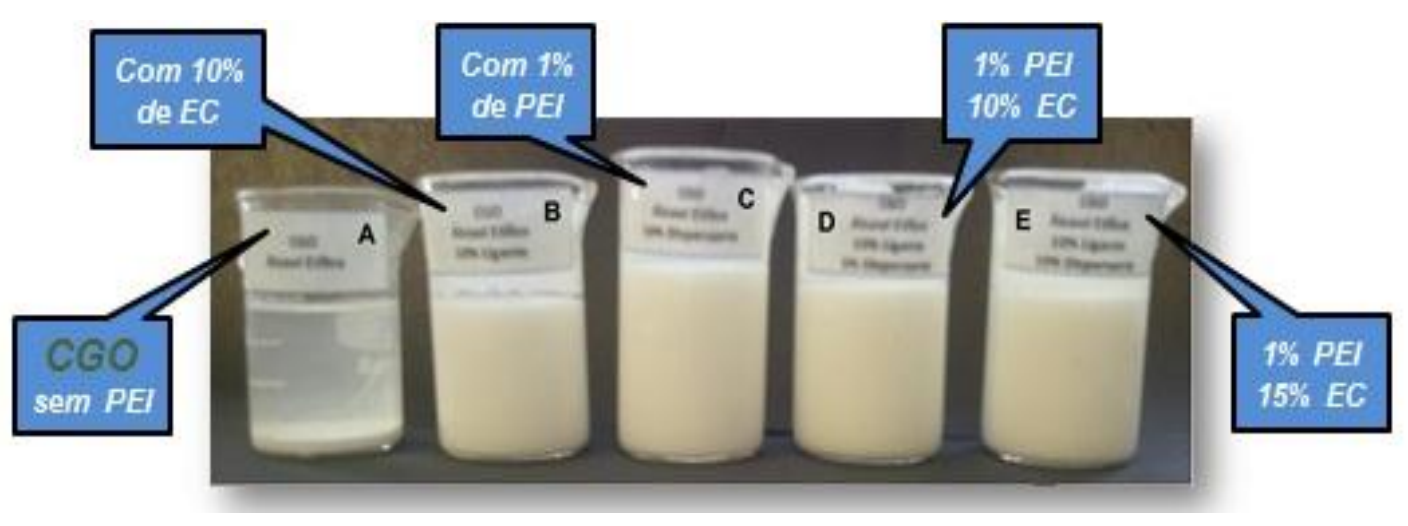

Figura 5.35 - Estabilidades das suspensões de CGO sem (A) e com adição de $1 \%$ de PEI (C), em função da decantação.

$\mathrm{Na}$ Figura 5.35, verificou-se as suspensões contendo particulados de CGO sem a adição (A) e com a adição (C) de 1\% (em massa) de PEl, além do comportamento da suspensão quando se adiciona $10 \%$, também em massa, de etilcelulose (EC), que possui a função de ligante (Figura 5.35, imagem B). 
Em seguida, foram produzidas suspensões de CGO envolvendo dispersante e ligante simultaneamente (Figura $5.35 \mathrm{D}$ e E) e comparou-se os efeitos quando ambos estão adicionados em conjunto. A imagem $D$ representa a suspensão de CGO com adição de 1\% de dispersante PEI e 10\% de ligante EC, enquanto que a imagem $E$ representa a suspensão com adição de $1 \%$ de dispersante PEI e $15 \%$ de ligante EC. Comparando todas as imagens, verifica-se que apenas $1 \%$ de PEI é suficiente para estabilizar a suspensão. Entretanto, a utilização de $10 \%$ de EC é importante para o processo de sinterização. Todas as porcentagens envolvidas são expressas em \% em massa total.

Essa concentração de EC foi estabelecida com base nos dados da literatura técnica ${ }^{(37 ; 101)}$, pois a concentração de $10 \%$ em massa foi suficiente para evitar trincas durante a secagem e sinterização. Foram avaliadas suspensões sem a presença de EC e com 10, 15 ou $20 \%$ em relação à massa dos particulados; sendo que, nas deposições das suspensões sem o ligante, ocorreu o aparecimento de pequenas trincas nas camadas formadas após a secagem e, consequentemente, prejudicou sua sinterização. Nas suspensões com $10 \%$ ou mais de ligante, não ocorreram aparecimentos de trincas tanto na secagem das camadas depositadas como na etapa de sinterização, não sendo necessário adicioná-lo em quantidades superiores a $10 \%$ para evitar descolamento das camadas durante e após o processo de sinterização.

Em decorrência dos resultados e com o objetivo de evitar o aparecimento de trincas na secagem e sinterização dos filmes micrométricos, utilizava 10\% em massa de ligante EC na preparação de todas as suspensões.

Para a determinação da quantidade mais adequada de particulados (quantidade de sólidos), foram preparadas suspensões variando a concentração de LSCF a 5, 10, 15 e 20\% em massa. As suspensões de LSCF foram padronizadas com $1,0 \%$ de $\mathrm{PEI}$ e $10 \%$ de EC em álcool etílico.

A suspensão com $10 \%$ de concentração de sólidos foi considerada a mais adequada, pois a com apenas $5 \%$ de concentração, apresentou um filme com espessura mais fina (para o mesmo número de deposições para formação do filme micrométrico) de LSCF, como pode ser observado por microscopia eletrônica de varredura da seção transversal das camadas de LSCF (Figura 5.36). 


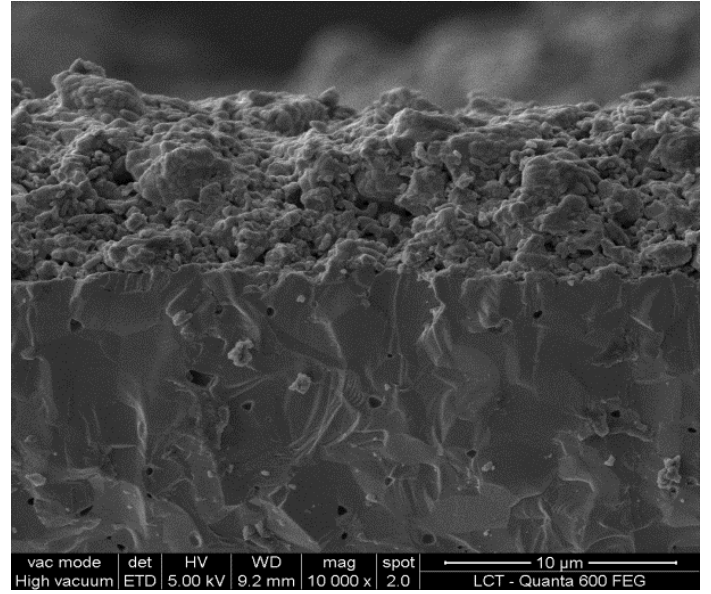

(a)

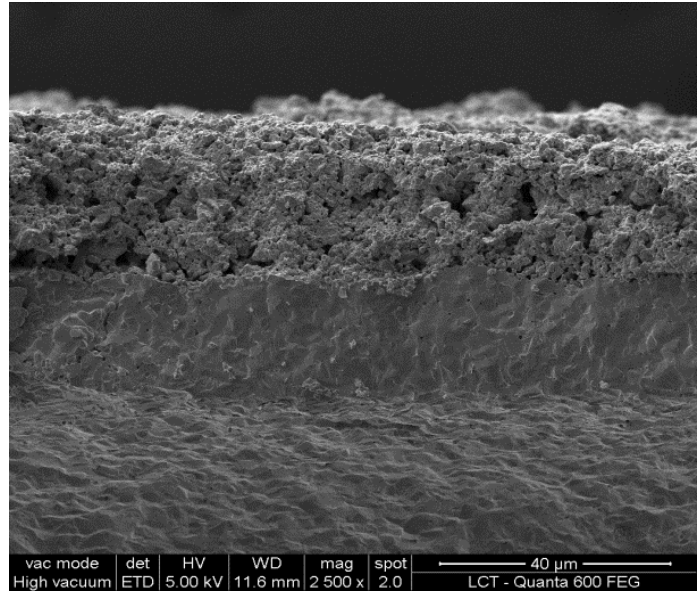

(b)

Figura 5.36 - Micrografias dos filmes de LSCF preparados com suspensões orgânicas a 5\% (a) e 10\% (b) de concentração de sólidos.

Para as suspensões com 15 ou 20\% de concentração de sólidos, não foi possível finalizar a aplicação de todos os filmes, pois durante a aplicação, ocorreu entupimento do bocal do aerógrafo, impossibilitando a escolha desta concentração para obter a espessura pretendida.

As suspensões de LSCF foram otimizadas para o estudo das meiacélulas cátodo/eletrólito com a composição de 10\% de concentração de sólidos, $1 \%$ de PEI, $10 \%$ de EC e álcool etílico. Em seguida, as suspensões dos compósitos LSCFCGO (LSCFCGO13, LSCFCGO11 e LSCFCGO31) e também a suspensão de CGO foram otimizadas com as mesmas concentrações do LSCF.

Para a preparação das suspensões, os valores de porcentagem de concentração de sólidos foram em relação ao solvente álcool etílico e as porcentagens de $\mathrm{PEI}$ e EC foram em relação à concentração de sólidos.

As suspensões orgânicas de LSCF e LSCFCG011 foram caracterizadas quanto à viscosidade e ao comportamento reológico. Nestas análises, as suspensões foram avaliadas com relação à técnica de conformação (aerografia) a ser aplicada para a formação dos filmes micrométricos.

A Figura 5.37 ilustra as curvas de viscosidades em função da taxa de cisalhamento para suspensões de LSCF e LSCFCGO11 contendo concentração a $10 \%$ em massa de sólidos com $10 \%$ em massa de ligante etilcelulose sobre 0 total de particulados presentes na suspensão. 


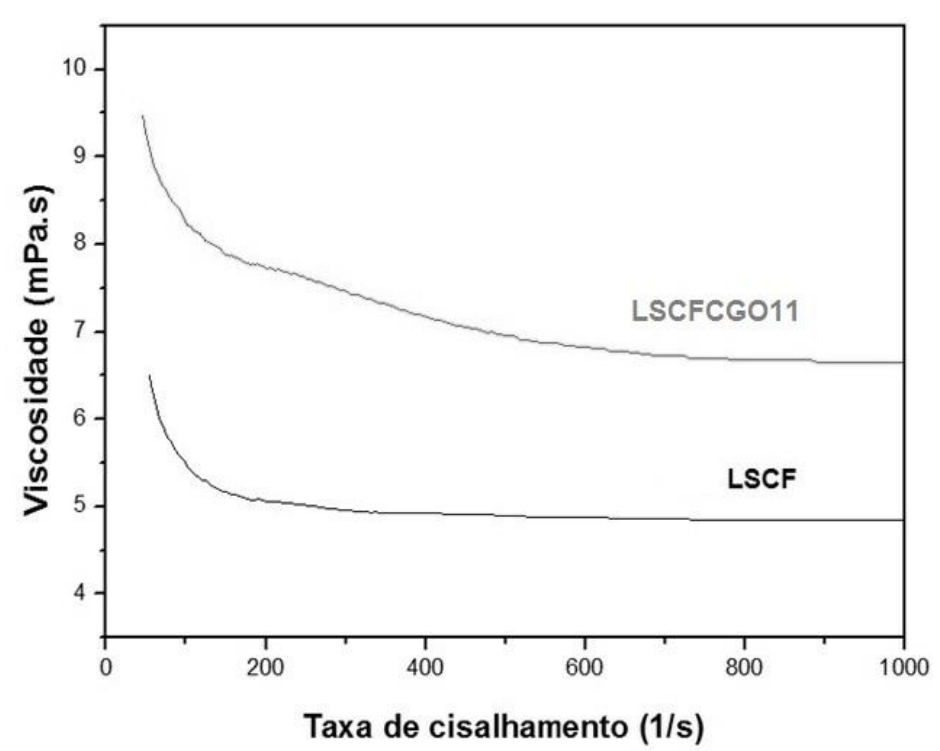

Figura 5.37 - Curvas de viscosidades das suspensões de LSCF e LSCFCGO11.

A curva de viscosidade do LSCF apresentou valores inferiores quando comparados com a do LSCFCGO11. Ambas as suspensões apresentaram decréscimos nos valores de viscosidade com o aumento da taxa de cisalhamento. Os compósitos (LSCFCGO) possuem a mistura de dois óxidos (LSCF e CGO) distintos, com densidades diferentes, auxiliando no aumento da viscosidade, com o aumento da taxa de cisalhamento. A Figura 5.38 ilustra as curvas de fluxos para as suspensões de LSCF e LSCFCGO11.

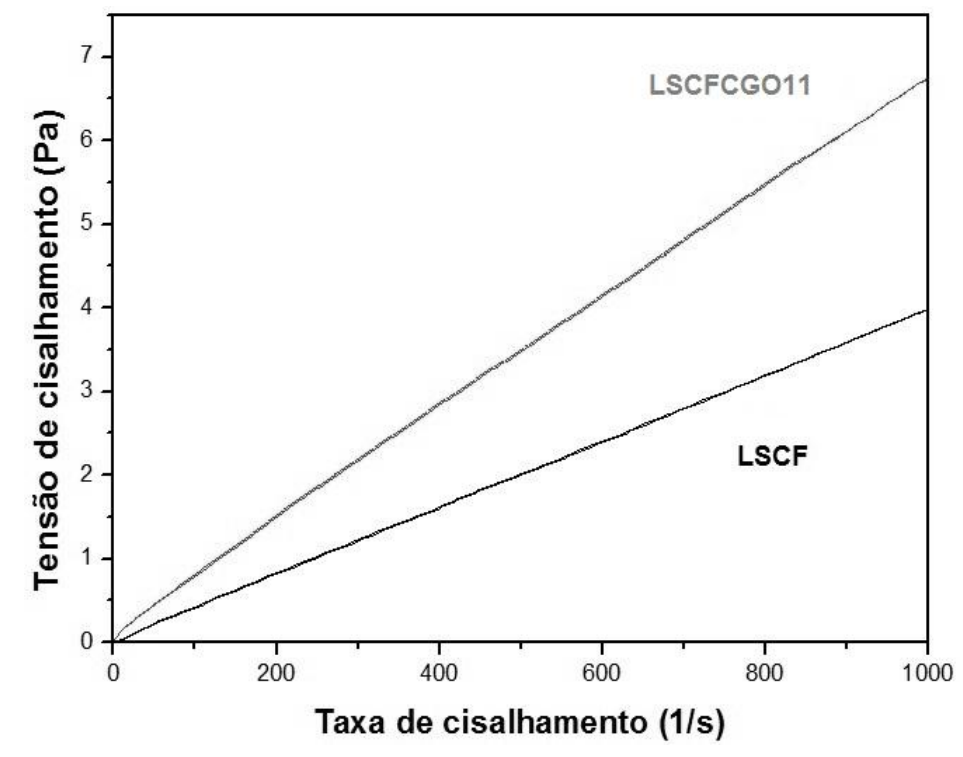

Figura 5.38 - Curvas de fluxo para as suspensões de LSCF e LSCFCGO. 
As curvas apresentam um comportamento reológico conhecido como pseudoplasticidade, pois é caracterizado por uma diminuição da viscosidade do fluido com o aumento da taxa e/ou a tensão de cisalhamento.

As suspensões de LSCF e LSCFCGO11 se apresentaram adequadas para serem aplicadas utilizando aerógrafo, pois é aconselhável utilizar viscosidade menor que $10 \mathrm{mPa}^{*} \mathrm{~s}$, ou seja, alta taxa de cisalhamento para materiais cerâmicos depositados por spray ${ }^{(37)}$.

\subsection{Caracterização das células unitárias}

Após a parte de caracterização dos materiais particulados, dos mesmos em forma de cerâmicas consolidadas, das suspensões cerâmicas envolvendo o LSCF, os compósitos da série LSCFCGO e também de CGO, foi realizado o processamento cerâmico para a montagem das células unitárias, visando caracterizações físicas e eletroquímicas.

As superfícies dos filmes de LSCF, compósitos LSCFCGO e CGO sobre os substratos de CGO ou YSZ, além da seção transversal dos filmes que constituem a célula unitária LSCF-LSCFCGO-CGO-YSZ, são reveladas nas diferentes imagens da Figura 5.39.

Analisando as imagens da Figura 5.39, pode-se observar pastilhas cilíndricas representando uma célula unitária, sendo que a imagem $\mathbf{A}$ refere-se ao filme micrométrico de LSCF sobre o substrato de CGO; a imagem $\mathbf{B}$ refere-se ao filme micrométrico de LSCFCGO sobre o substrato de CGO; a imagem $\mathbf{C}$ referese ao filme de LSCF sobre o filme de LSCFCGO sobre o substrato de CGO; a imagem $\mathbf{D}$ refere-se somente ao substrato de CGO; a imagem $\mathbf{E}$ refere-se ao filme de LSCF sobre filme de LSCFCGO sobre filme de CGO sobre o substrato de YSZ; a imagem $\mathbf{F}$ refere-se somente ao substrato de YSZ e, por fim, a imagem $\mathbf{G}$ refere-se a uma seção transversal da célula LSCF-LSCFCGO-CGO-YSZ ainda sem a presença do ânodo padrão constituído de um filme de platina.

Cada imagem tem o objetivo de mostrar as diferentes camadas que constituem a célula unitária do lado do cátodo LSCF até o eletrólito de YSZ. 


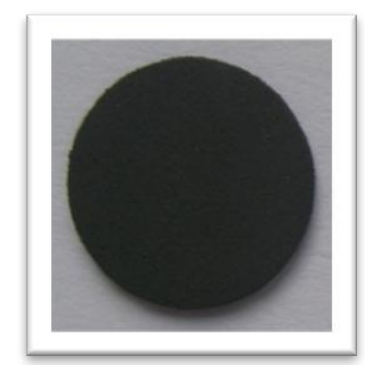

(A)

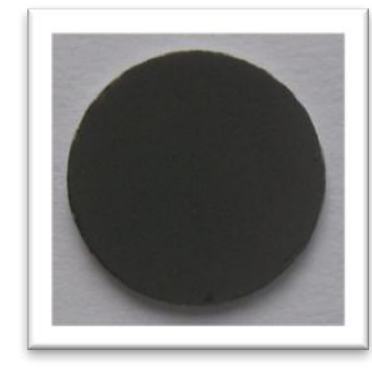

$(\mathrm{E})$

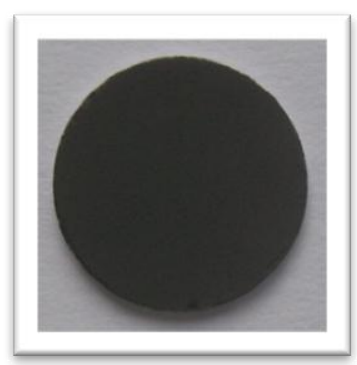

(B)

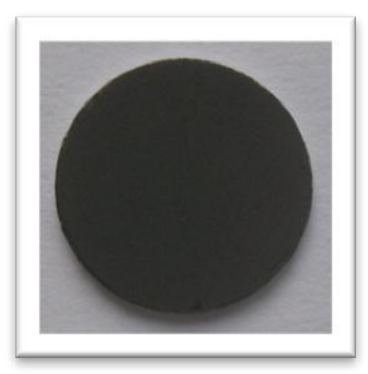

(C)

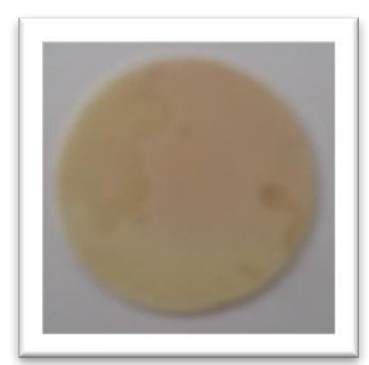

(D)

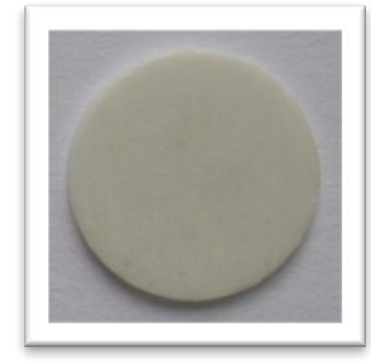

$(\mathbf{F})$

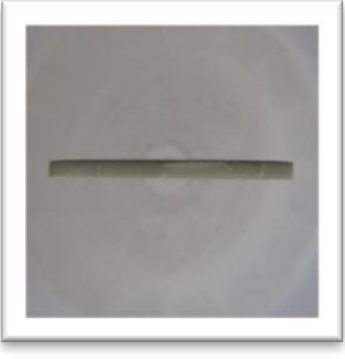

(G)

Figura 5.39- Superfícies dos filmes: LSCF (A), LSCFCGO (B), LSCF-LSCFCGO (C), substrato de CGO (D), LSCF-LSCFCGO-CGO (E), substrato de YSZ (F) e seção transversal da meia-célula LSCF-LSCFCGO-CGO-YSZ (G).

O substrato de CGO conformado por prensagem uniaxial e os filmes micrométricos dos compósitos LSCFCGO (meia-célula LSCFCGO - CGO) e LSCF (meia-célula LSCF - LSCFCGO - CGO), conformados por wet powder spraying deposition, foram caracterizados por microscopia eletrônica de varredura.

As micrografias da Figura 5.40 revelam as seções transversais das pastilhas sinterizadas e fraturadas contendo filmes micrométricos de LSCFCGO13 (A), LSCFCGO11+LSCFCGO13 (B), LSCFCGO31+LSCFCGO11+LSCFCGO13 (C) e LSCF+LSCFCGO31+LSCFCGO11+LSCFCGO13 (D) sobre o substrato denso do eletrólito sólido de CGO. Verificou-se que o substrato CGO é bastante denso e que as camadas micrométricas de LSCF e LSCFCGO possuem porosidade $(>30 \%)$ e com boa aderência no substrato. As morfologias dos filmes cerâmicos estão de acordo com dados da literatura ${ }^{(70)}$.

O filme possui uma espessura de aproximadamente $5 \mu \mathrm{m}$ para o compósito LSCFCGO31; $15 \mu \mathrm{m}$ para os compósitos LSCFCG011+LSCFCGO13 (A); $20 \mu \mathrm{m}$ para os compósitos LSCFCGO31+LSCFCGO11+LSCFCGO13 (B) e pouco mais de $30 \mu \mathrm{m}$ para a meia-célula (C). 


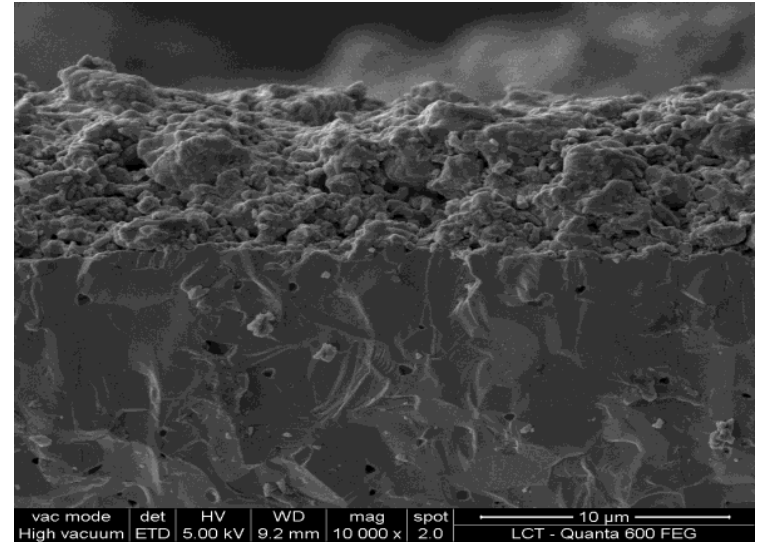

(A)

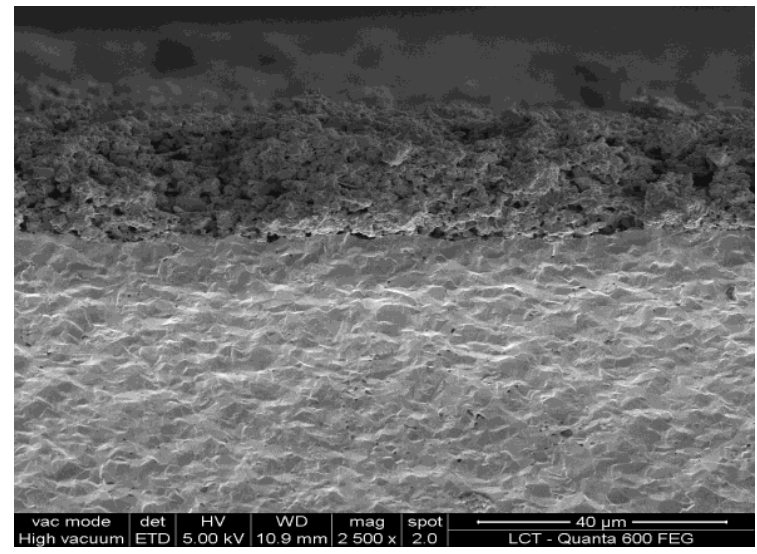

(C)

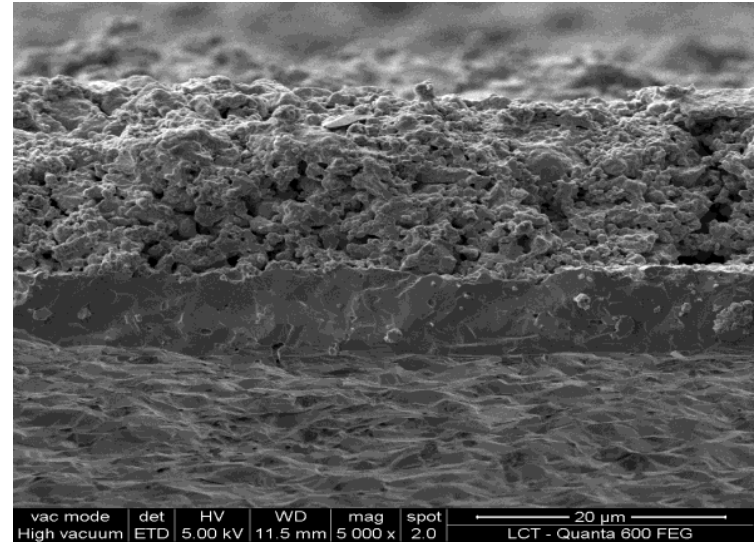

(B)

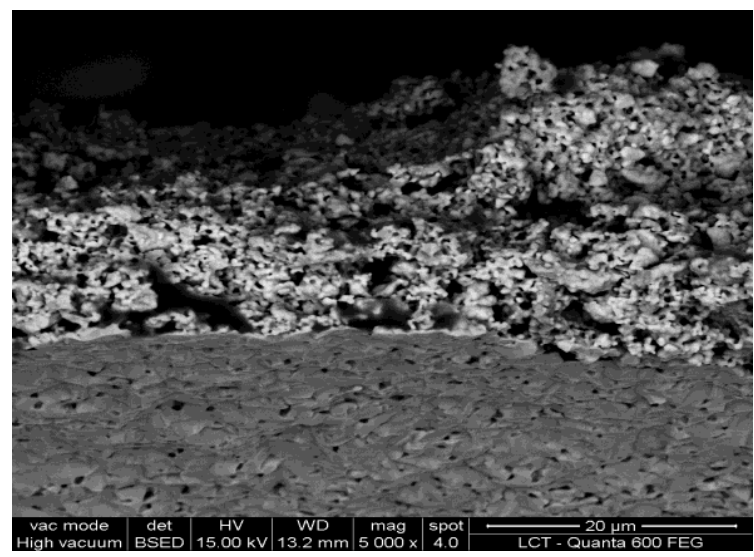

(D)

Figura 5.40 -Micrografias dos filmes micrométricos sobre substrato de CGO.

Segundo a literatura ${ }^{(92,96,98,101)}$, para conseguir uma espessura entre 30 e $40 \mu \mathrm{m}$, geralmente necessita-se de várias camadas da ordem de 3 a $5 \mu \mathrm{m}$ cada.

Para conseguir as espessuras desejadas, para os filmes de LSCFCGO, foram depositadas 3 camadas (uma para cada compósito, sendo cada camada constituída de três deposições), enquanto que para o filme de LSCF foram depositadas 12 camadas. Cada camada foi conformada realizando a deposição em quatro diferentes direções (como explicado no subcapítulo 4.3.4) com etapas intermediárias de secagem por 5 minutos ao ar. Após a deposição das camadas, os corpos de prova foram submetidos a sinterização a $1100^{\circ} \mathrm{C}$ por 1 hora.

De acordo com as micrografias, verifica-se que o uso do aerógrafo é adequado para produção de camadas micrométricas no substrato do eletrólito sólido, pois possui boa aderência com o substrato de CGO. Todas as micrografias evidenciam os diferentes aspectos morfológicos do substrato denso de CGO e das camadas porosas de LSCFCGO (A, B e C) e LSCF sobre LSCFCGO (D). 


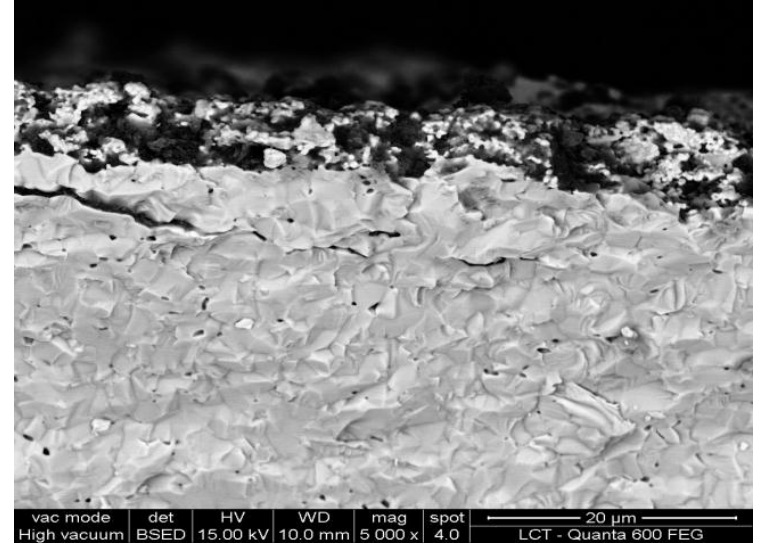

(A)

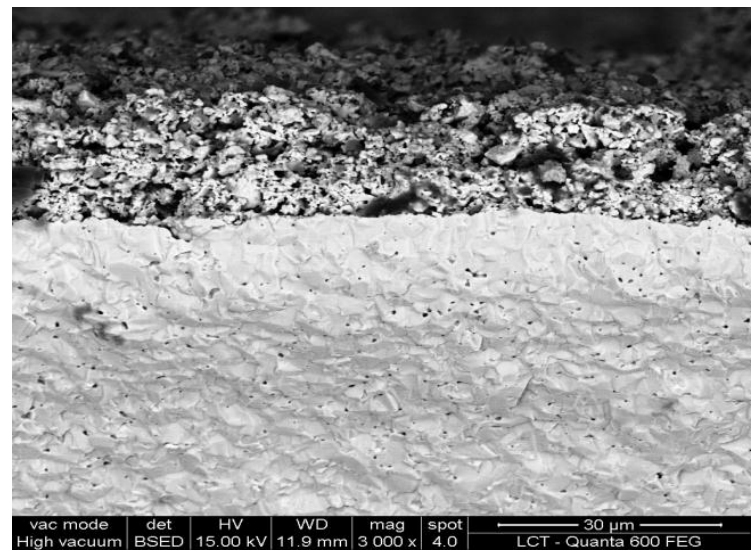

(C)

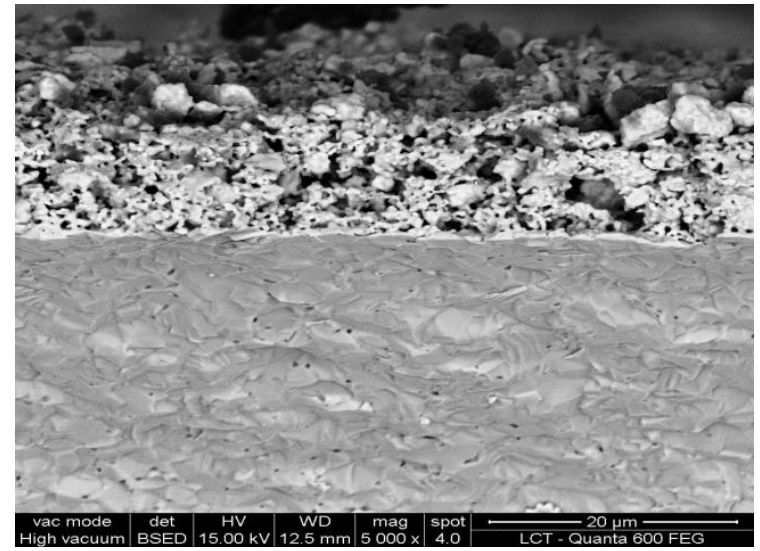

(B)

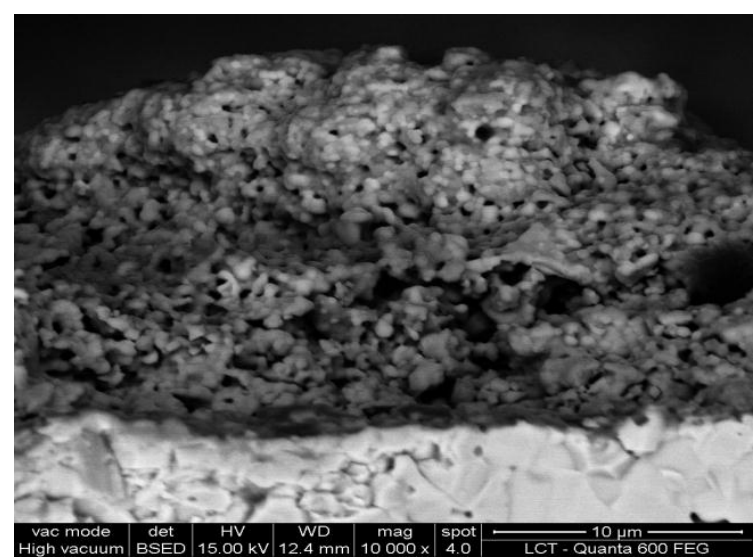

(D)

Figura 5.41 - Micrografias das seções transversais dos filmes sobre substrato de CGO utilizando feixe de elétrons retroespalhados.

Para os substratos de CGO e YSZ sinterizados antes da deposição dos filmes de LSCF, LSCFCGO (ou LSCF-CGO) e CGO, a densidade aparente foi analisada pelo método hidrostático. O valor das densificações da CGO e YSZ foi calculado por meio da razão da densidade hidrostática pela densidade teórica, apresentando um valor de 95,30\% para CGO e $98,20 \%$ para YSZ.

Em seguida, analisou-se por MEV-EDS, a seção transversal das meias-células fraturadas para a confirmação das espessuras e elementos constituintes nos filmes micrométricos de LSCFCGO sobre substrato de CGO (Figura 5.42) e também dos filmes micrométricos de LSCF e LSCFCGO sobre substrato de CGO (Figura 5.43). 

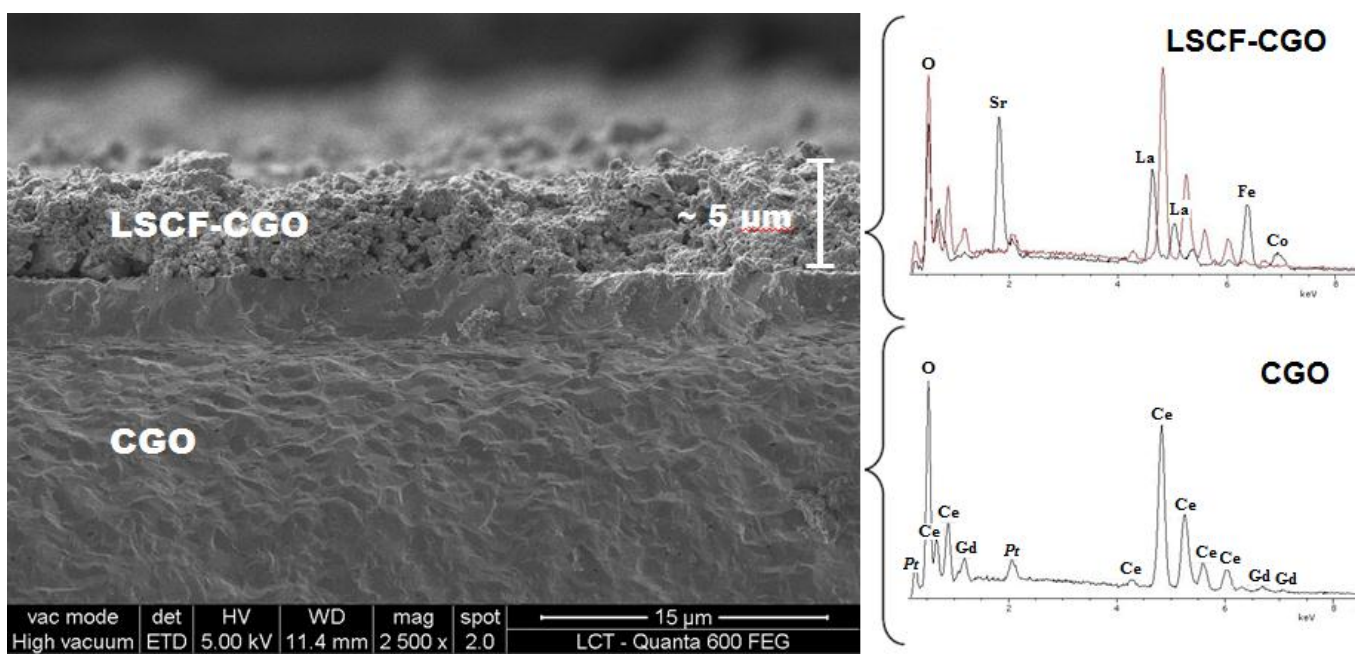

Figura 5.42 - Micrografia da seção transversal da meia célula constituída de filme LSCFCGO sobre substrato CGO.

A análise qualitativa das meia-células permitiu verificar que o substrato de CGO observado por MEV foi denso o suficiente para ser usado como eletrólito sólido e os filmes micrométricos de LSCF e LSCFCGO possuía espessuras e porosidades adequadas, além de boa aderência com o eletrólito. As morfologias dos filmes de LSCF e LSCFCGO foram semelhantes quando comparadas com a literatura técnica ${ }^{(103)}$, cujos filmes foram conformados pela técnica de serigrafia.

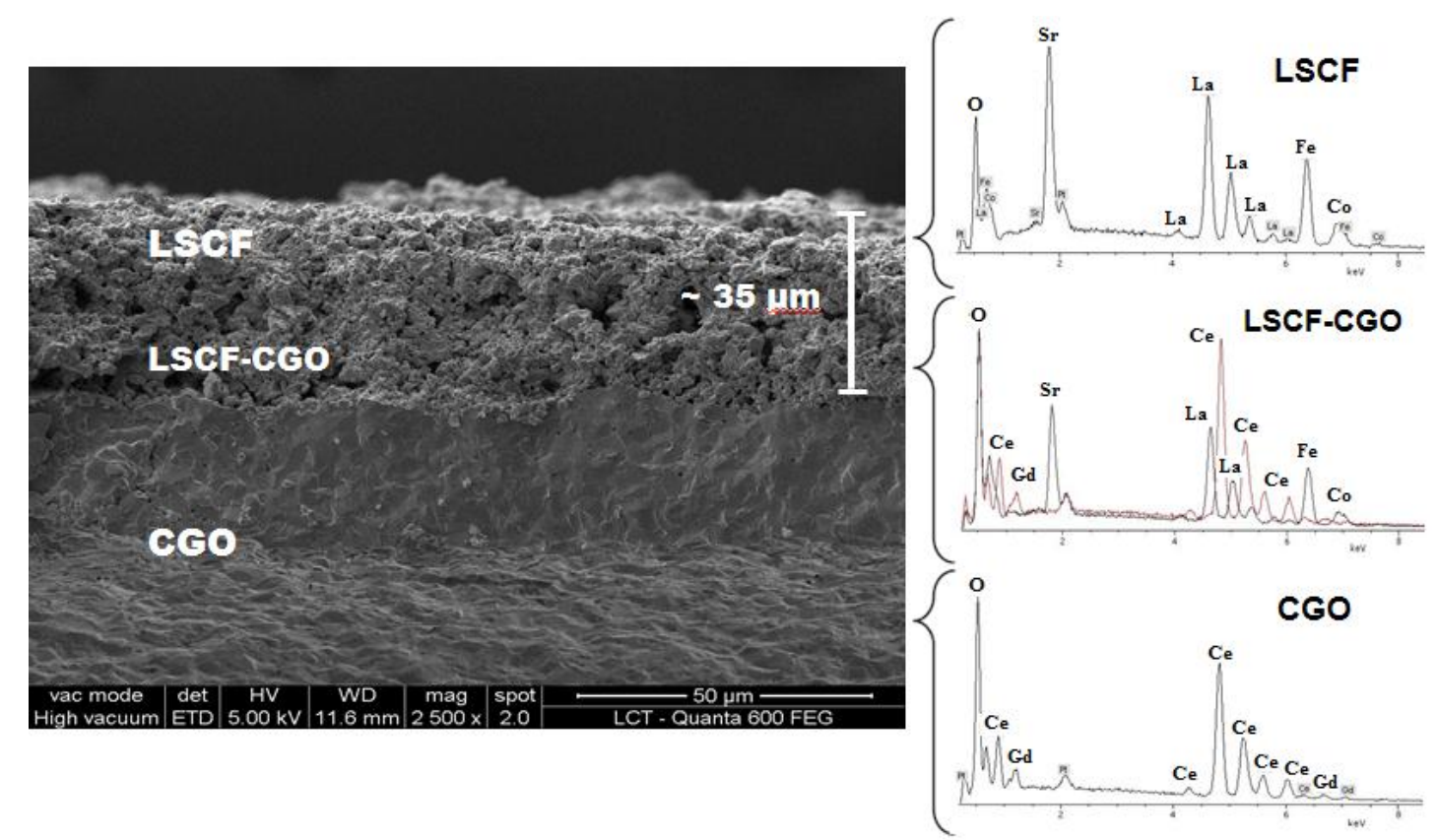

Figura 5.43 - Micrografia da seção transversal da meia célula constituída de filmes LSCF e LSCFCGO sobre substrato CGO. 
Por EDS, verificou-se que os picos característicos dos filmes micrométricos de LSCF e LSCFCGO e do substrato de CGO, possuíam somente os elementos químicos característicos de cada material.

Com relação à espessura das camadas e analisando as imagens obtidas por MEV, podemos estimar uma espessura de aproximadamente $5 \mu \mathrm{m}$ (Figura 5.42) para a camada do compósito LSCFCGO e 35 um (Figura 5.43) para a camada de LSCF. Para a formação do LSCFCGO, foram depositadas 3 camadas, enquanto que para o LSCF foram depositadas 12 camadas. Cada uma dessas camadas foi formada realizando a deposição em estágios intermediários e alternando com secagem ao ar por 5 minutos.

Para finalizar esta parte de estudo, analisou-se também por MEV-EDS, a seção transversal das meias-células fraturadas para a confirmação das espessuras e elementos constituintes nas camadas de LSCFCGO e CGO sobre substrato de YSZ (Figura 5.44) e também das camadas de LSCF, LSCFCGO e CGO sobre substrato de YSZ (Figura 5.45). É importante destacar que para todos os espectros de EDS analisados, foram identificados somente os elementos químicos característicos de cada material.

A análise qualitativa desta metade da célula unitária permitiu verificar que o substrato de YSZ, observado por MEV, é bastante denso para ser utilizado como eletrólito sólido e, as camadas de LSCF, LSCFCGO e CGO possuíam espessuras e porosidades adequadas, além de boa aderência com o eletrólito.

A morfologia dos filmes é semelhante quando comparada com a literatura técnica ${ }^{(104)} \mathrm{e}$, por EDS, verificou-se também que os picos característicos das fases de LSCF, LSCFCGO e CGO, além do substrato de YSZ, possuíam os elementos químicos característicos de cada material, sendo que não houve contaminação na camada LSCF mais LSCFCGO pela CGO e também não foi encontrada contaminação na camada de CGO por LSCF ou YSZ.

Analisando as imagens obtidas por MEV, estimou-se uma espessura de aproximadamente $10 \mu \mathrm{m}$ (Figura 5.44) para a camada de CGO e de $35 \mu \mathrm{m}$ (Figura 5.45) para a camada contendo LSCF mais LSCFCGO.

Para a formação do CGO, foram depositadas 3 camadas e para a formação do LSCFCGO, foram depositadas 3 camadas (uma de cada cátodo compósito), enquanto que para o LSCF, foram depositadas 12 camadas. Cada camada foi formada da mesma forma que a célula unitária anterior. 


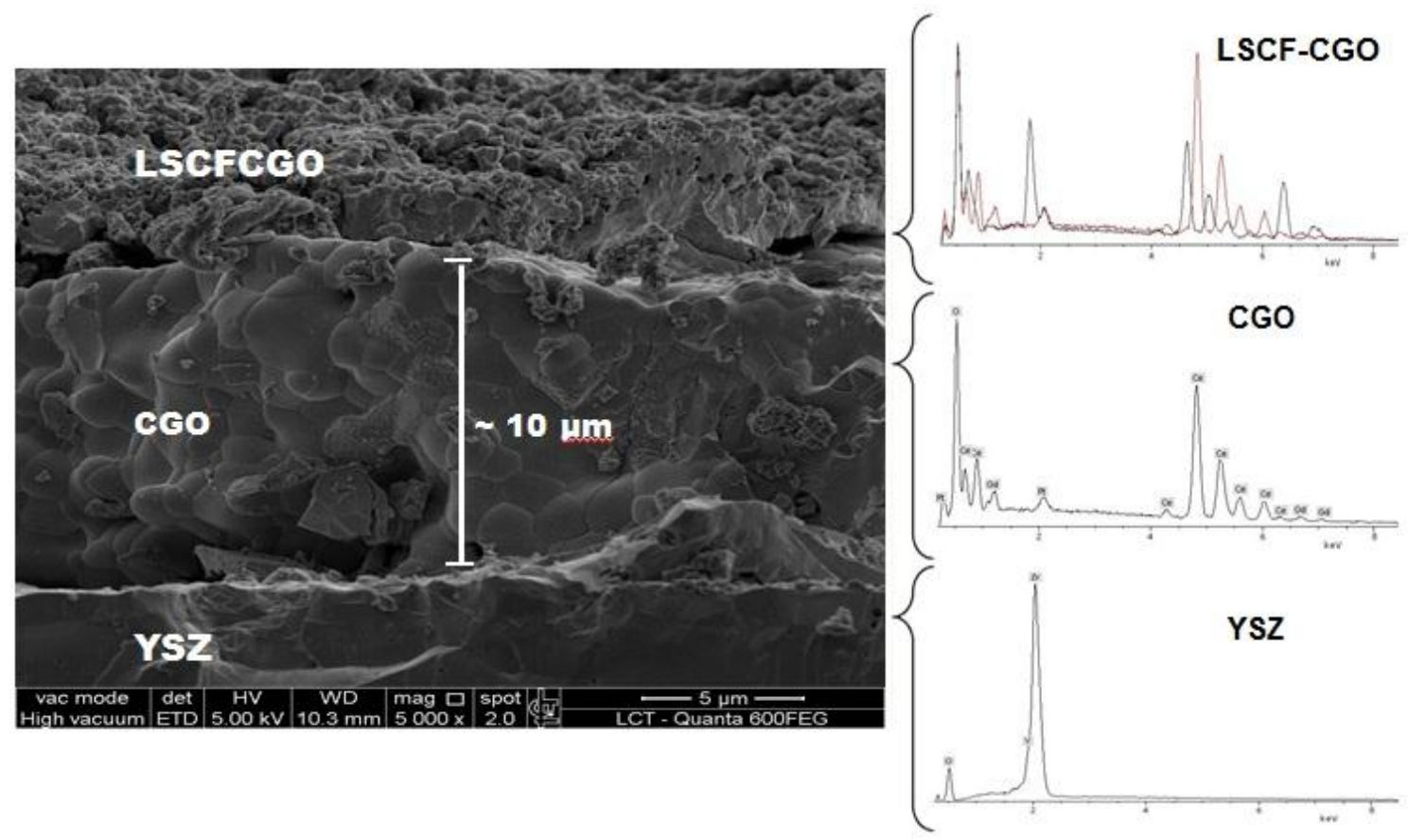

Figura 5.44 - Micrografia da seção transversal da meia célula constituída de filmes LSCGCGO e CGO sobre substrato YSZ.
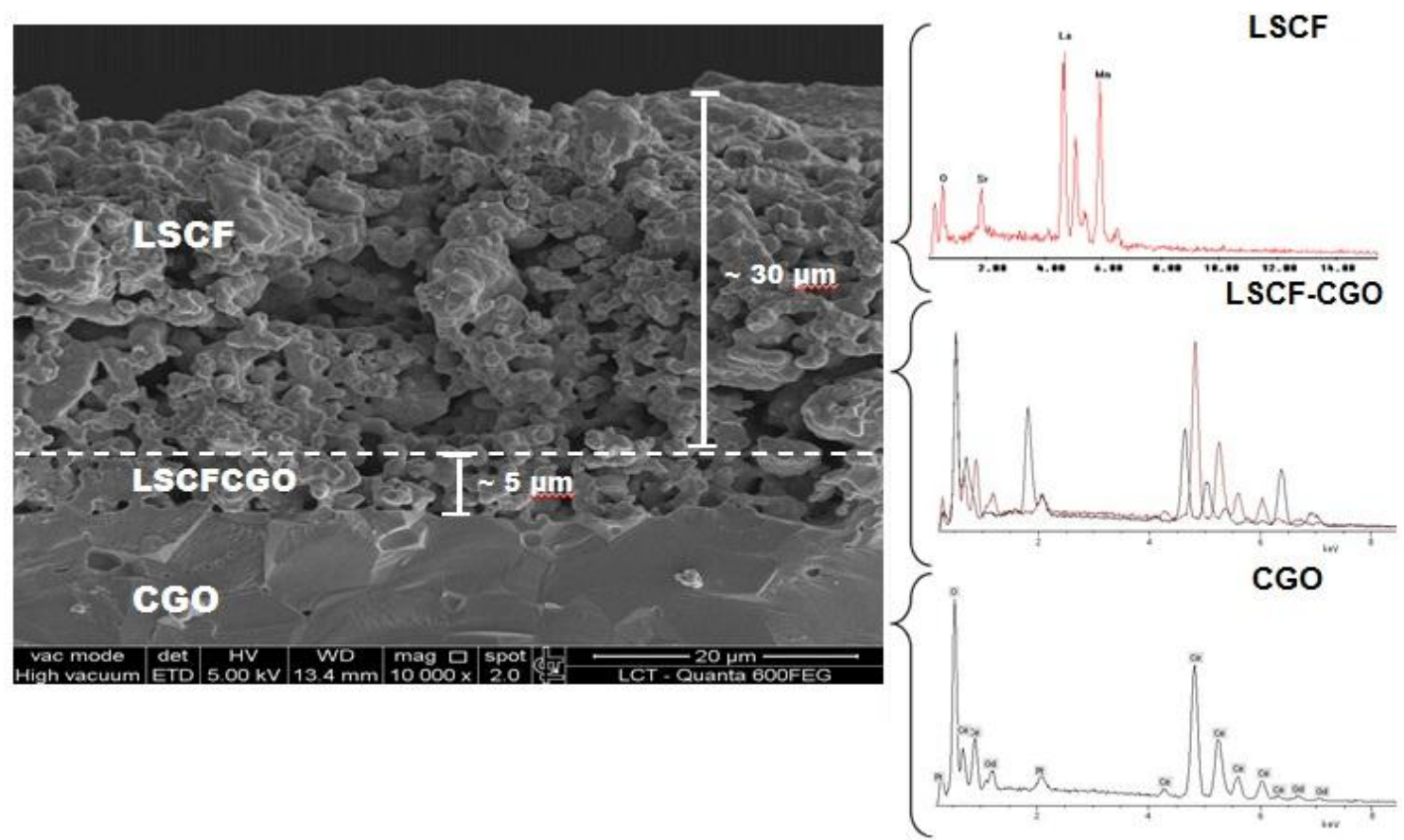

Figura 5.45 - Micrografia da seção transversal da meia célula constituída de filmes LSCF, LSCFCGO e CGO sobre substrato YSZ. 


\subsection{Caracterização eletroquímica das meia-células}

As caracterizações eletroquímicas das meia-células propostas no trabalho foram realizadas após preparação dos contatos elétricos (em ambos os lados) seguido de tratamento térmico a $900^{\circ} \mathrm{C}$ por 1 hora em forno $L I N D B E R G$, modelo BLUE M. O desempenho dos cátodos LSCF e LSCFCGO foi interpretado e comparado com dados da literatura e com curvas de polarização e de impedância eletroquímica para os seguintes sistemas:

Sistemas: $\mathrm{H}_{2(\mathrm{~g})} \mid$ ânodo | eletrólito | cátodo $\mid \mathrm{O}_{2(\mathrm{~g})}$.

Sistema A: $\mathrm{H}_{2(\mathrm{~g})} \mid \mathrm{Pt}$ | CGO | LSCFCGO e LSCF | $\mathrm{O}_{2(\mathrm{~g})}$

Sistema B: $\mathrm{H}_{2(\mathrm{~g})}|\mathrm{Pt}|$ YSZ e CGO | LSCFCGO e LSCF $\mid \mathrm{O}_{2(\mathrm{~g})}$.

Onde:

$\mathrm{H}_{2(g)}=$ gás hidrogênio sendo alimentado no ânodo de Pt.;

$\mathrm{Pt}$ = ânodo padrão de platina;

CGO e YSZ = eletrólitos;

LSCFCGO = cátodo compósito (camada intermediária);

LSCF = cátodo;

$\mathrm{O}_{2(\mathrm{~g})}=$ oxigênio sendo alimentado no ânodo de LSCF.

As medidas foram realizadas nas temperaturas de 500, 550, 600, $650 \mathrm{e}$ $700^{\circ} \mathrm{C}$, que representam as temperaturas atuais para a operação de uma ITSOFC, alimentada normalmente com ar sintético. Nesta etapa, os eletrólitos possuem espessura de aproximadamente $0,40 \mathrm{~mm}$ (após a retificação).

O desempenho eletroquímico do cátodo LSCF juntamente com o cátodo compósito LSCFCGO foi interpretado por meio das curvas de polarização corrigidas com queda ôhmica; ou seja, os componentes resistivos (resistências do eletrólito, eletrodo, interfaces e contatos elétricos) não foram considerados neste ensaio de caracterização eletroquímica, principalmente para proporcionar informações mais específicas sobre a influência das outras polarizações decorrente do próprio eletrodo. 
Normalmente a cinética de operação, em baixas densidades de corrente, é determinada principalmente pela polarização por ativação, pela atividade da reação em altas densidades de corrente e pela polarização por concentração, devido à insuficiência das espécies reagentes nos eletrodos.

Para a obtenção das curvas corrigidas, os valores dos Resistores $\left(R_{i}\right)$ foram identificados e relacionados aos componentes resistivos, nas medidas de impedância, para os mesmos potenciais medidos na curva de polarização. Com isso, os valores obtidos experimentalmente foram ajustados à curva do circuito elétrico equivalente (Figura 5.46) e assim, identificados para cada potencial ${ }^{(33)}$.

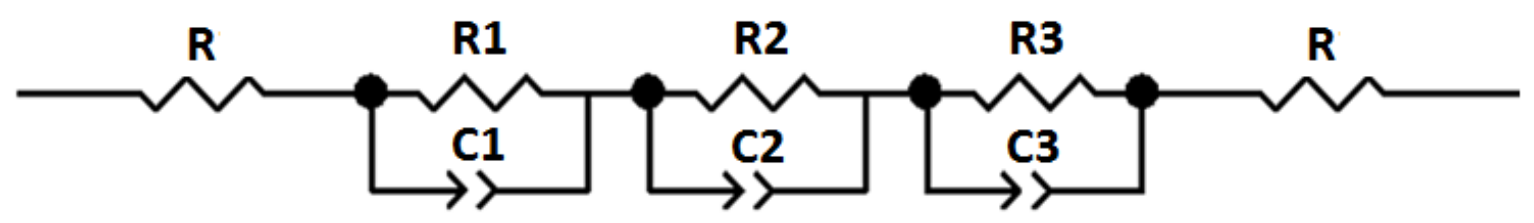

Figura 5.46 - Circuito equivalente para a caracterização elétrica por impedância.

Onde:

$\mathrm{R}=$ Resistor;

$\mathrm{C}=$ Capacitor.

A escolha do circuito elétrico representado na Figura 5.46, se deve a um melhor ajuste dos dados experimentais das curvas de impedância eletroquímica, apresentando um erro percentual médio de mais ou menos $2 \%$ para os valores de $\mathrm{R}_{\mathrm{i}}$. Para todas as amostras, a área analisada é de aproximadamente $1,50 \mathrm{~cm}^{2}$.

As curvas de polarização (Figuras 5.47 e 5.48) com correção de queda ôhmica para as duas células unitárias analisadas (sistema $\mathbf{A}$ e sistema $\mathbf{B}$ ) foram representadas no gráfico, envolvendo as grandezas potencial $(V)$ e potência $\left(\mathrm{mW} / \mathrm{cm}^{2}\right)$ em função da grandeza densidade de corrente $\left(\mathrm{mA} / \mathrm{cm}^{2}\right)$, no intervalo de temperaturas que abrange $500^{\circ} \mathrm{C}$ até o máximo de $650^{\circ} \mathrm{C}$. 


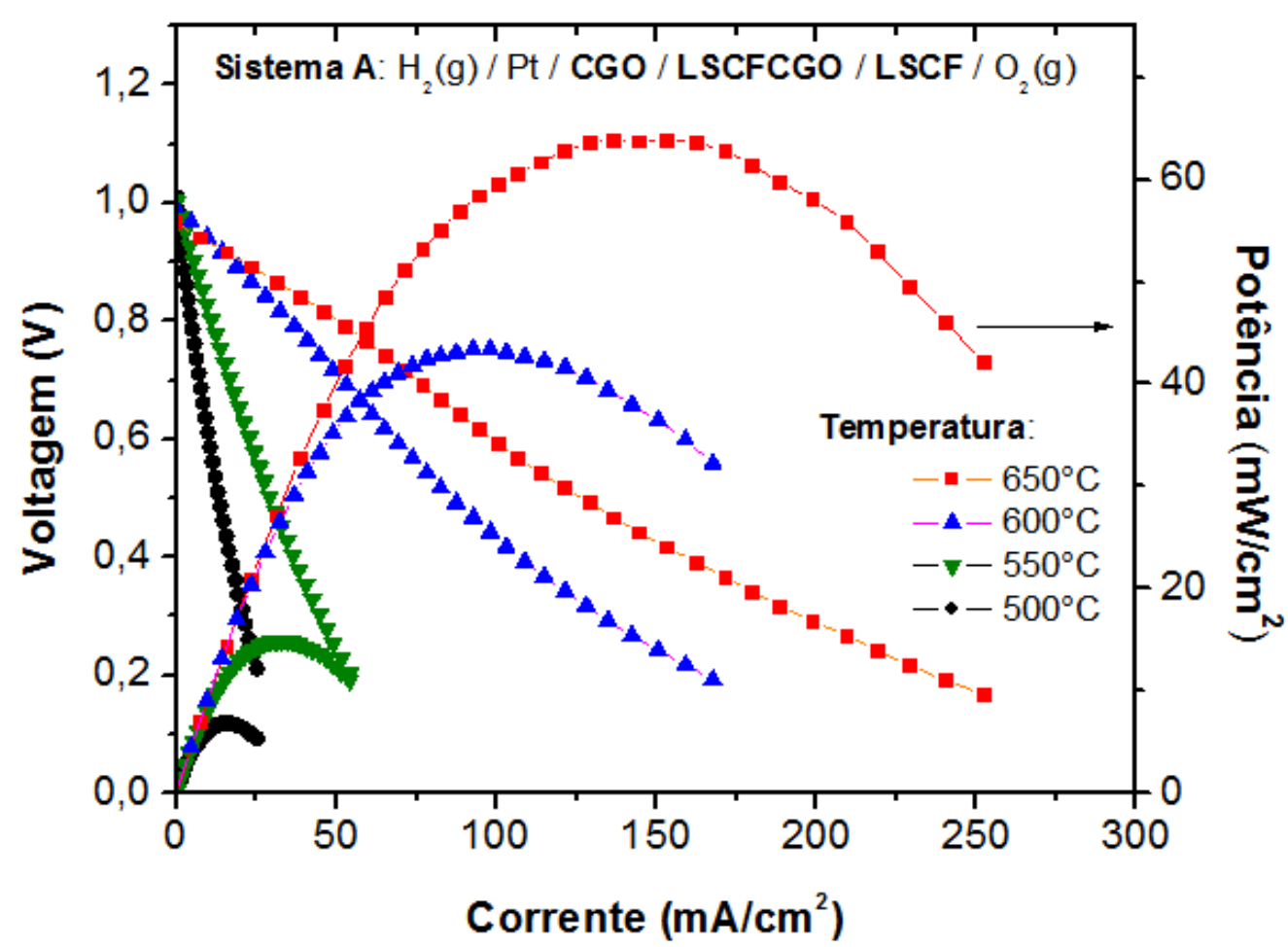

Figura 5.47 - Curvas de polarização do sistema A.

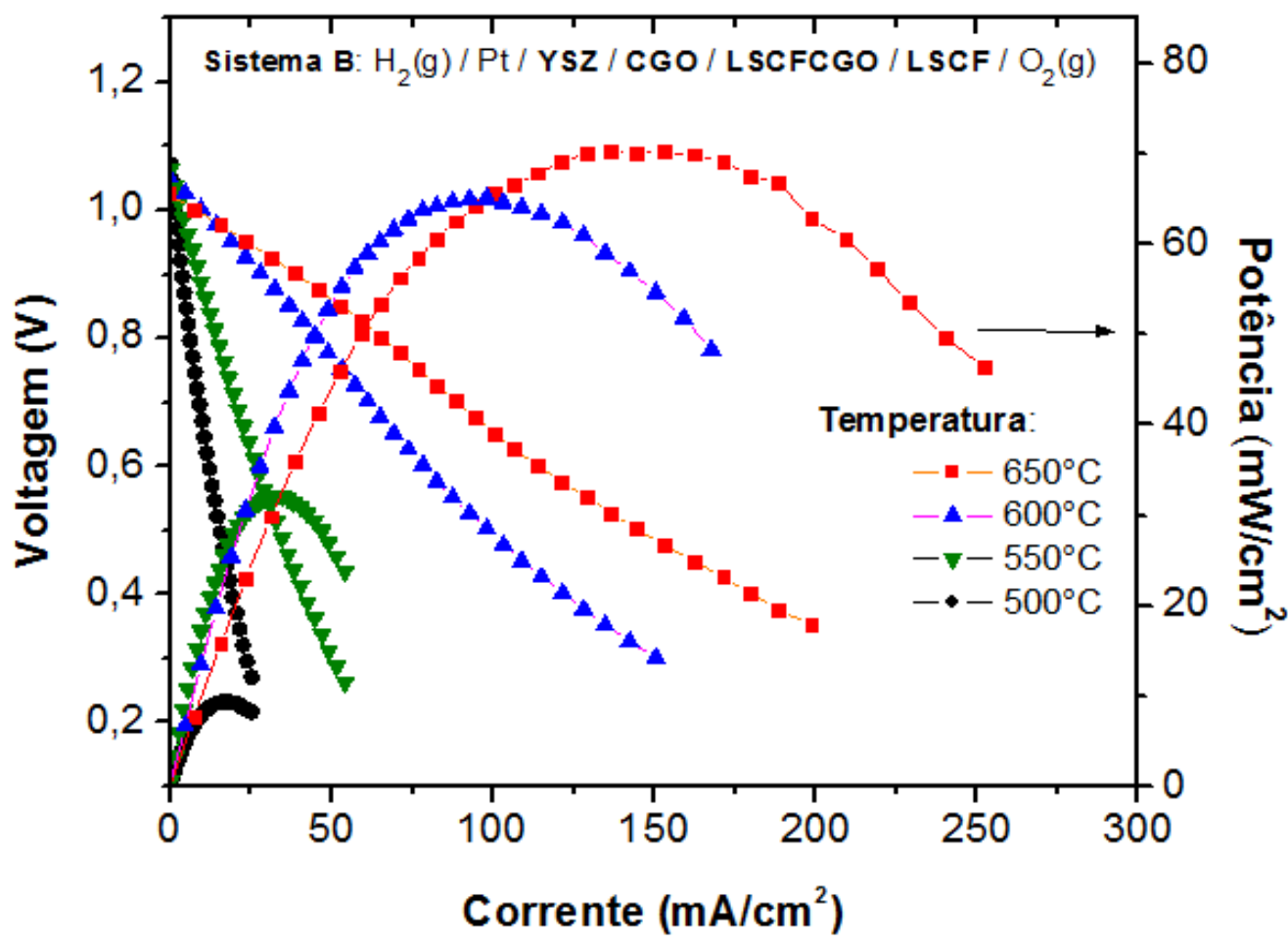

Figura 5.48 - Curvas de polarização do sistema B. 
As curvas de polarização do sistema $\mathrm{A}$ apresentam uma diferença significativa após a correção de queda ôhmica, indicando que as resistências correspondentes à polarização, ocasionadas pela queda ôhmica, não foram consideradas. Observa-se nas Figuras 5.47 e 5.48 que para um determinado valor de potencial, a densidade de corrente é maior para as células unitárias que operam entre 600 e $650^{\circ} \mathrm{C}$.

Nas Figuras 5.49 e 5.50 são apresentados os diagramas de impedância eletroquímica, obtidos até $750^{\circ} \mathrm{C}$, utilizando-se ânodos de platina e cátodos de LSCF, sinterizados a $1100^{\circ} \mathrm{C}$ por $1 \mathrm{~h}$. Analisando as Figuras mencionadas, verificaram-se curvas que possuem a característica de dois diferentes semicírculos. O semicírculo de frequências mais elevadas (normalmente com frequências superiores a $10^{5} \mathrm{~Hz}$ ) está relacionado com as contribuições dos grãos das amostras para sua resistividade elétrica total, e o semicírculo de frequências mais baixas (inferiores a $10^{5} \mathrm{~Hz}$ ) estão relacionados com as contribuições dos contornos de grãos das amostras para a mesma resistividade elétrica. $O$ valor da resistividade elétrica total é determinado pela interseção, em mais baixa frequência, do semicírculo relativo ao contorno grão e o eixo das abscissas no diagrama de impedância ${ }^{(127)}$.

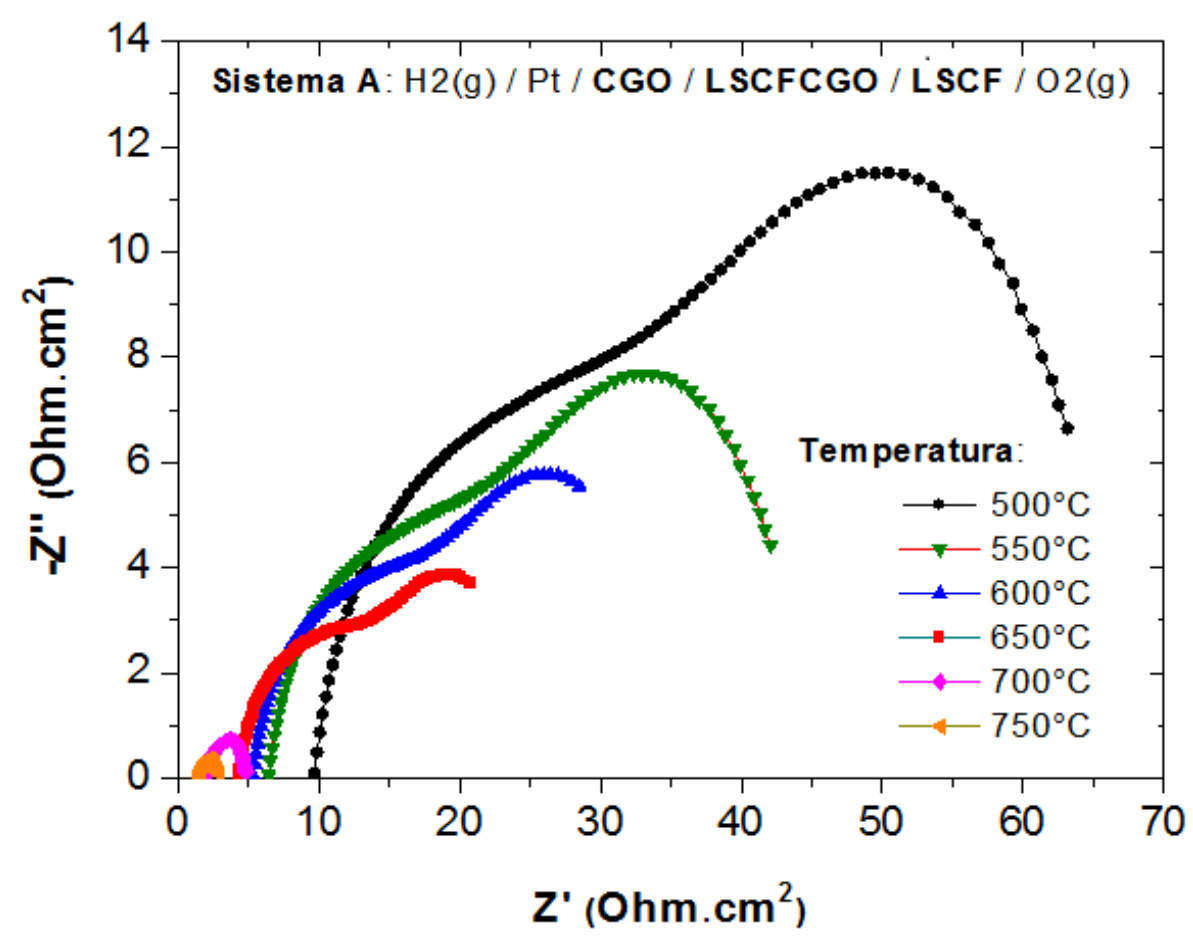

Figura 5.49 - Impedância eletroquímica do sistema A. 


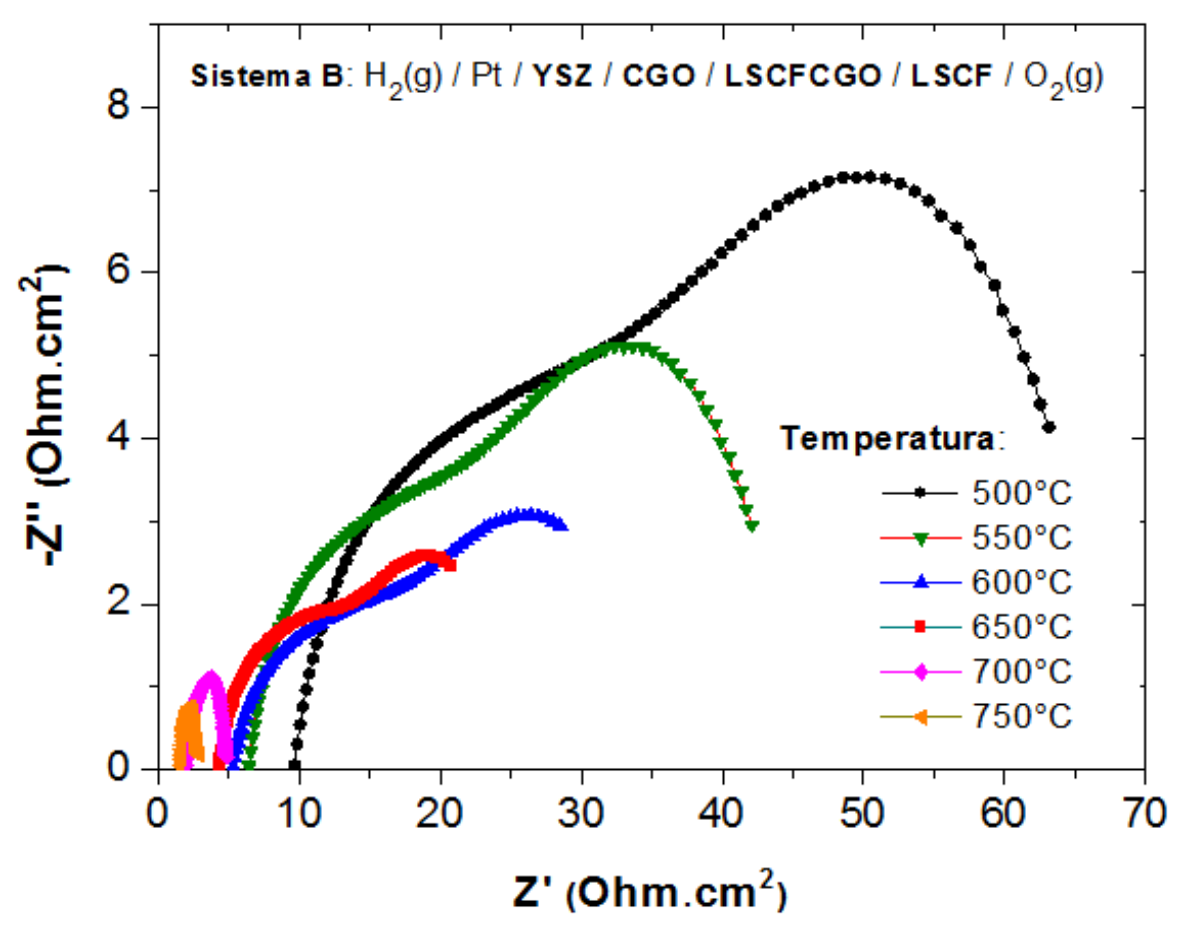

Figura 5.50 - Impedância eletroquímica do sistema B.

Analisando os pontos que se assemelham a semicírculos, podemos observar que dois arcos de semicírculo podem ser ajustados e relacionados com dois circuitos R/C ligados em série ${ }^{(127)}$. Esses arcos estão relacionados com os diferentes processos que determinam a resistência de polarização dos eletrodos (cátodo e ânodo) em uma célula a combustível típica. A cinética do cátodo LSCF+LSCFCGO indica que com uma densidade de corrente abaixo de aproximadamente $150 \mathrm{~mA} / \mathrm{cm}^{2}$, o potencial desvia significativamente em relação ao potencial de circuito aberto, favorecendo a RRO na região da TBP.

De acordo com os resultados nos dois sistemas, verificou-se que o compósito LSCFCGO possui funcionalidade e auxilia significativamente 0 transporte de cargas na interface do cátodo com o eletrólito, melhorando os processos de transferências de cargas do eletrodo. Este desempenho se deve ao cátodo compósito LSCFCGO, que aumentou a região da TPB.

NIELSEN, J. et al. ${ }^{(69)}$, demonstraram que a polarização pode ser diminuída aumentando a condutividade iônica do eletrólito ou introduzindo camadas micrométricas de condutores mistos entre um eletrólito e o eletrodo. 
Em outro trabalho, SAHU, A.K. et al. ${ }^{(128)}$, o eletrodo confeccionado com a adição de YSZ ao LSM melhorou a condutividade, diminuindo a polarização do material, além de evitar a formação da fase resistiva composta de zirconato de lantânio e conhecida pela sigla LZO.

A porosidade foi distribuída mais homogeneamente no filme micrométrico composto pelo compósito LSCFCGO sobre LSCF, quando comparado ao filme constituído apenas de LSCF. Essa é uma característica importante, a qual contribui para a diminuição da polarização por concentração.

Nas curvas de polarizações a $600^{\circ} \mathrm{C}$, podemos observar que com uma diferença de potencial de aproximadamente $0,40 \mathrm{~V}$, o cátodo LSCF+LSCFCGO apresentou uma densidade de corrente da ordem de $100 \mathrm{~mA} / \mathrm{cm}^{2}$, para o sistema A; e de $25 \mathrm{~mA} / \mathrm{cm}^{2}$, para o sistema B. Comparando os resultados, confirmou-se um aumento de $25 \%$ quando se utilizou como eletrólito principal, o YSZ.

Nas curvas de polarizações a $650^{\circ} \mathrm{C}$, podemos observar que, com um potencial de aproximadamente $0,40 \mathrm{~V}$, o cátodo LSCF+LSCFCGO apresentou uma densidade de corrente da ordem de $160 \mathrm{~mA} / \mathrm{cm}^{2}$, para o sistema $A$; e da ordem de $175 \mathrm{~mA} / \mathrm{cm}^{2}$, para o sistema B. Determinou-se um aumento de $8,57 \%$ quando se utilizou novamente a YSZ como eletrólito principal e confirmando que o cátodo compósito é necessário para um melhor desempenho do cátodo.

Após os ajustes das curvas de impedância eletroquímica no intervalo de potencial de pouco mais de $0 \Omega . \mathrm{cm}^{2}$ até $65 \Omega . \mathrm{cm}^{2}$, foram obtidos valores de resistência correspondente às temperatura de 600 e $650^{\circ} \mathrm{C}$.

Para o sistema $A$, o cátodo LSCF+LSCFCGO possui uma resistência de aproximadamente $6,00 \Omega \cdot \mathrm{cm}^{2}$ a $600^{\circ} \mathrm{C}$ e de cerca de $3,25 \Omega . \mathrm{cm}^{2}$ a $650^{\circ} \mathrm{C}$; enquanto que para o sistema $B$, a resistência é de aproximadamente $4,00 \Omega . \mathrm{cm}^{2}$ a $600^{\circ} \mathrm{C}$ e de cerca de $2,50 \Omega . \mathrm{cm}^{2}$. Com este resultado, verificou-se que a reação de redução do oxigênio foi mais eficiente no sistema $B$, pois ocorreram diminuições das resistências a 600 e $650^{\circ} \mathrm{C}$, em decorrência da utilização do eletrólito de CGO depositado sobre o eletrólito suporte de YSZ. 


\section{CONCLUSÕES}

Os particulados de LSCF podem ser sintetizados pela técnica dos citratos e os particulados de LSCFCGO por mistura mecânica de sólidos, com a formação de fase única de estrutura cristalina ortorrômbica (LSCF) e cúbica (CGO), e com composições reais aproximadas às composições nominais, confirmadas por Fluorescência raios $X(F R X)$ de por Difração de raios $X(D R X)$ com o refinamento pelo método de Rietveld.

As condições de calcinação adotadas em diferentes temperaturas $(700$, 800,900 e $1000^{\circ} \mathrm{C}$ ) para os particulados de LSCF foram adequadas para remoção do carbono residual de forma gradativa, ou seja, maior a temperatura de calcinação, menor o teor de carbono no material. A temperatura de $800^{\circ} \mathrm{C}$ por 4 horas foi suficiente para sintetizar o LSCF sem a formação de fases secundárias.

As micrografias dos particulados de LSCF e LSCFCGO revelaram partículas na forma de aglomerados, com os tamanhos inferiores a $1 \mu \mathrm{m}$. Tais resultados foram confirmados com os obtidos para os diâmetros médios das partículas e áreas superficiais específicas e estão de acordo com o tamanho dos particulados comerciais e que foram adequados para a preparação de suspensões estáveis com a presença de pouco dispersante.

O preparo das suspensões de LSCF, dos compósitos LSCFCGO e CGO foi adequado para conformação de filmes finos por wet powder spraying, sobre substrato de CGO ou YSZ conformados por prensagem uniaxial e isostática, retificados para diminuição da espessura e lixados para a introdução de ranhuras visando auxílio para fixação dos filmes em suas superfícies. Para a preparação das suspensões, utilizou-se 1\% (em massa) de polietilenoimina (PEI) e 10\% (em massa) de etilcelulose (EC) com relação ao teor de sólidos presentes na suspensão a base de álcool etílico.

Pela técnica utilizada, foi possível preparar suspensões estáveis por até 24 horas, conseguindo espessuras da ordem de micrômetros para a deposição dos filmes por meio de um processo considerado de baixo custo.

A porosidade para os filmes de LSCF e LSCFCGO foi de aproximadamente $29 \%$ e $22 \%$, respectivamente, e a densificação para os substratos foi de $96,8 \%$ para CGO e $98,3 \%$ para YSZ, sendo interessante para aplicação na ITSOFC. 
As espessuras de até $40 \mu \mathrm{m}$ para os filmes do cátodo LSCF mais cátodo compósito LSCFCGO (espessura total) são adequadas com o objetivo de facilitar a difusão do oxigênio e sua reação de redução.

Por FRX verificou-se a formação dos particulados de LSCF e do compósito LSCFCGO, confirmando uma estequiométrica real muito próxima da nominal. Os elementos químicos presentes nas meia-células e suas composições (em \% atômica) foram confirmados por EDS.

A micrografia da superfície de fratura polida e tratada termicamente revelou tamanhos de grãos maiores para o filme LSCF do que para o filme do compósito LSCFCGO. Com este resultado, confirmou-se a importância do cátodo compósito para a diminuição das resistências elétricas, devido a um menor tamanho de grão associado a uma maior quantidade de contornos de grãos, contribuindo para melhorar significativamente as respostas elétricas do material.

As curvas de polarizações a $600^{\circ} \mathrm{C}$ revelaram um potencial de $0,40 \mathrm{~V}$ para o cátodo LSCF+LSCFCGO, possuindo uma densidade de corrente da ordem de $100 \mathrm{~mA} / \mathrm{cm}^{2}$, para o sistema A (sistema contendo o eletrólito de CGO); e da ordem de $125 \mathrm{~mA} / \mathrm{cm}^{2}$, para o sistema B (sistema contendo o eletrólito de CGO + YSZ). Comparando os resultados, determinou-se um aumento de $25 \%$ quando se utilizou o LSCFCGO com eletrólito de CGO depositado sobre YSZ.

As curvas de impedância eletroquímica revelaram que para o sistema A, o cátodo LSCF+LSCFCGO possui uma resistência elétrica de aproximadamente $6,00 \Omega . \mathrm{cm}^{2}$ a $600^{\circ} \mathrm{C}$ e de cerca de $3,25 \Omega . \mathrm{cm}^{2}$ a $650^{\circ} \mathrm{C}$ enquanto que para o sistema $B$, a resistência foi de aproximadamente $4,00 \Omega . \mathrm{cm}^{2}$ a $600^{\circ} \mathrm{C}$ e de cerca de $2,50 \Omega \mathrm{cm}^{2}$ para $650^{\circ} \mathrm{C}$. As respostas elétricas revelaram que a utilização do cátodo compósito LSCFCGO foi essencial para uma melhora na densidade de corrente, em função do aumento da região TBP. A utilização da YSZ como eletrólito principal, contendo um filme micrométrico de CGO, resultou em um aumento significativo nos valores de densidade de corrente e diminuição nas resistências, se comparado ao eletrólito somente composto de CGO

A conformação por wet powder spraying é uma técnica relativamente simples e que mostrou ser possível fabricar filmes micrométricos porosos de LSCF e LSCFCGO aderentes sobre substratos densos de CGO ou YSZ, para a utilização em células unitárias nas ITSOFCs. 


\section{SUGESTÕES PARA TRABALHOS FUTUROS}

A partir dos resultados obtidos nesta Tese, são sugeridos como temas relevantes para trabalhos futuros:

- Estudar o processamento e caracterização da célula unitária com foco no ânodo pela mesma técnica utilizada neste trabalho para um posterior estudo de células unitárias (cátodo/eletrólito/ânodo);

- Caracterizar eletricamente as células unitárias, otimizando as propriedades microestruturais para uma melhor condutividade elétrica;

- Caracterizar eletricamente as células simulando diferentes condições de operação entre 450 e $650^{\circ} \mathrm{C}$;

- Estudar as propriedades mecânicas das células unitárias, fundamentalmente na engenharia do empilhamento das células a combustível de óxido sólido.

- Estudar a configuração cilíndrica para a célula unitária da ITSOFC. 


\section{REFERÊNCIAS BIBLIOGRÁFICAS}

1. RIFKIN, J. A economia do hidrogênio. São Paulo: M. Books do Brasil Ltda, 2003.

2. KORDESCH, K.; SIMADER, G. Fuel Cells and their applications. New York: VHC, 1996.

3. ADALBÓ, R. Célula combustível a hidrogênio: fonte de energia da nova era. São Paulo: Artiliber Editora Ltda, 2004.

4. EG\&G Technical Services, Parsons, Inc. Science Applications Corporation Fuel cell handbook. Washington: U.S. Department of Energy: 2004.

5. LINARDI, M. Introdução à tecnologia de células a combustível. São Paulo: Artliber Editora Ltda, 2010.

6. MINH, N. Q. Solid oxide fuel cell technology - Features and applications. Solid State Ion., v. 174, n. 1-4, p. 271-277, 2004.

7. RING, T. A. Fundamentals of ceramic powder processing and synthesis. San Diego (California): Academic Press, 1996.

8. BOCH, P.; NIÈPCE, J.-C. Ceramic materials: processes, properties and applications. London, UK: ISTE Ltd., 2007.

9. MINH, N. Q. Solid oxide fuel cells for power generation and hydrogen production. J. Korean Ceram. Soc., v. 47, n. 1, p. 1-7, 2010.

10. SINGHAL, S. C. Solid oxide fuel cells: Status, challenges and opportunities. Ind. Ceram., v. 28, n. 1, p. 53-59, 2008.

11. MINH, N. Q.; SINGHAL, S. C.; WILLIAMS, M. C. Solid oxide fuel cells: Development activities, trends and technological challenges. ECS Transactions, p. 211-219, 2009.

12. SINGHAL, S. C. Advances in solid oxide fuel cell technology. Solid State Ion., v. 135, n. 1-4, p. 305-313, 2000.

13. WANG, S. et al. High temperature properties of $\mathrm{La}_{0.6} \mathrm{Sr}_{0.4} \mathrm{Co}_{0.8} \mathrm{Fe}_{0.2} \mathrm{O}_{3-\delta}$ phase structure and electrical conductivity. Solid State Ion., v. 159, n. 1-2, p. 71-78, 2003.

14. QIU, L. et al. $\mathrm{Ln}_{1-\mathrm{x}} \mathrm{Sr}_{x} \mathrm{Co}_{1-y} \mathrm{Fe}_{y} \mathrm{O}_{3-\delta}(\mathrm{Ln}=\mathrm{Pr}, \mathrm{Nd}, \mathrm{Gd} ; \mathrm{x}=0.2,0.3)$ for the electrodes of solid oxide fuel cells. Solid State Ion., v. 158, n. 1-2, p. 55-65, 2003. 
15. CHATZICHRISTODOULOU, C. et al. Oxygen Permeation in Thin, Dense $\mathrm{Ce}_{(0.9)} \mathrm{Gd}_{(0.1)} \mathrm{O}_{(1.95 \text {-delta) }}$ Membranes II. Experimental Determination. J. Electrochem. Soc., v. 158, n. 5, p. F73-F83, 2011.

16. CHANG, H.-C. et al. A ceria layer as diffusion barrier between LAMOX and lanthanum strontium cobalt ferrite along with the impedance analysis. Solid State Ion., v. 180, n. 4-5, p. 412-417, Apr 272009.

17. WANG, S. et al. Performance of a $\mathrm{La}_{0.6} \mathrm{Sr}_{0.4} \mathrm{Co}_{0.8} \mathrm{Fe}_{0.2} \mathrm{O}_{3}-\mathrm{Ce}_{0.8} \mathrm{Gd}_{0.2} \mathrm{O}_{1.9}-\mathrm{Ag}$ cathode for ceria electrolyte SOFCs. Solid State Ion., v. 146, n. 3-4, p. 203210, 2002.

18. LEE, S. et al. LSCF-SDC core-shell high-performance durable composite cathode. J. Power Sources, v. 195, n. 1, p. 118-123, 2010.

19. YASHIRO, N.; USUI, T.; KIKUTA, K. Application of a thin intermediate cathode layer prepared by inkjet printing for SOFCs. J. Eur. Ceram. Soc., v. 30, n. 10, p. 2093-2098, 2010.

20. PECHINI, M. P. Method of preparing lead and alkaline-earth titanates and niobates and coating method using the same to form capacitors. United States Patent Office no 3.330.697, Massachusetts, USA, 1967.

21. LESSING, P. A. Mixed-cation oxide powders via polymeric precursors. Am. Ceram. Soc. Bull., v. 68, n. 5, p. 1002-1007, 1989.

22. TIETZ, F. et al. Evaluation of commercial nickel oxide powders for components in solid oxide fuel cells. J. Eur. Ceram. Soc., v. 20, n. 8, p. 1023-1034, 2000.

23. VARGAS, R. A. et al. Síntese e caracterização dos pós de $\mathrm{Nd}_{1-x} \mathrm{Sr}_{x} \mathrm{MnO}_{3}$ e $\mathrm{La}_{1-x} \mathrm{Sr}_{x} \mathrm{Co}_{1-y} \mathrm{FeyO}_{3}$. Rio de Janeiro: Matéria (UFRJ). 12: 8-21 p. 2007.

24. PARK, Y. M.; KIM, J. H.; KIM, H. In situ sinterable cathode with nanocrystalline $\mathrm{La}_{0.6} \mathrm{Sr}_{0.4} \mathrm{Co}_{0.2} \mathrm{Fe}_{0.8} \mathrm{O}_{3-\delta}$ for solid oxide fuel cells. Int. J. Hydrogen Energ., v. 36, n. 9, p. 5617-5623, 2011.

25. LU, Z. et al. Extended reaction zone of $\mathrm{La}_{(0.6)} \mathrm{Sr}_{(0.4)} \mathrm{Co}_{(0.2)} \mathrm{Fe}_{(0.8)} \mathrm{O}_{(3)}$ cathode for solid oxide fuel cell. J. Power Sources, v. 198, p. 90-94, Jan 152012.

26. MINH, N. Recent advances in solid oxide fuel cell technology. Am. Ceram. Soc. Bull., v. 82, n. 7, 2003.

27. SINGH, P.; MINH, N. Q. Solid oxide fuel cells: Technology status. Int. J. Appl. Ceram. Tec., v. 1, n. 1, p. 5-15, 2004. 
28. FU, C. J. et al. A promising Ni-Fe bimetallic anode for intermediatetemperature SOFC based on Gd-doped ceria electrolyte. Int. J. Hydrogen Energ., v. 36, n. 21, p. 13727-13734, 2011.

29. GHOUSE, M. et al. Preparation of $\mathrm{La}_{(0.6)} \mathrm{Sr}_{(0.4)} \mathrm{Co}_{(0.2)} \mathrm{Fe}_{(0.8)} \mathrm{O}_{(3)}$ nanoceramic cathode powders for solid oxide fuel cell (SOFC) application. Int. J. Hydrogen Energ., v. 35, n. 17, p. 9411-9419, Sep 2010.

30. TUCKER, M. C.; CHENG, L.; DEJONGHE, L. C. Selection of cathode contact materials for solid oxide fuel cells. J. Power Sources, v. 196, n. 20, p. 8313-8322, 2011.

31. ROUTBORT, J. L. et al. Deformation of perovskite electronic ceramics - a review. Solid State Ion., v. 129, n. 1-4, p. 53-62, 2000.

32. FLORIO, D. Z. et al. Materiais cerâmicos para células a combustível: Cerâmica. 50:275-290 p. 2004.

33. TICIANELLI, E. A.; GONZALEZ, E. R. Eletroquímica. São Paulo: Edusp Editora da Universidade de São Paulo, 2005.

34. BAUMANN, F. S. et al. Impedance spectroscopic study on well-defined $(\mathrm{La}, \mathrm{Sr})(\mathrm{Co}, \mathrm{Fe}) \mathrm{O}_{3}$-delta model electrodes. Solid State Ion., v. 177, n. 11-12, p. 1071-1081, Apr 2006.

35. FRAY, D.; VARGA, Á.; TAN, J. C. Types of fuel cells. Disponível em: < http://www.doitpoms.ac.uk/tiplib/fuel-cells/types.php >. Acesso em: 6 jun. 2011.

36. SETZ, L. F. G. Processamento coloidal de cromito de lantânio. Instituto de Pesquisas Energéticas e Nucleares, IPEN-CNEN/SP, Universidade de São Paulo (USP), Tese de Doutorado, São Paulo, 2009.

37. CHIBA, R. Síntese, processamento e caracterização de meia células de óxido sólido catodo/eletrólito de manganito de lantânio dopado com estrôncio/zircônia estabilizada com ítria. Instituto de Pesquisas Energéticas e Nucleares, IPEN-CNEN/SP, Universidade de São Paulo (USP), Tese de Doutorado, São Paulo, 2010.

38. SINGHAL, S. C.; KENDALL, K. High-temperature Solid Oxide Fuel Cells: Fundamentals, Design and Applications. Elsevier, 2003.

39. FAN, B.; YAN, J.; SHI, W. A high performance solid oxide fuel cells operating at intermediate temperature with a modified interface between cathode and electrolyte. J. Eur. Ceram. Soc., v. 30, n. 8, p. 1803-1808, Jun 2010. 
40. MICHAEL C, T. Progress in metal-supported solid oxide fuel cells: A review. J. Power Sources, v. 195, n. 15, p. 4570-4582, 2010.

41. LENG, Y.; CHAN, S. H.; LIU, Q. Development of LSCF-GDC composite cathodes for low-temperature solid oxide fuel cells with thin film GDC electrolyte. Int. J. Hydrogen Energ., v. 33, n. 14, p. 3808-3817, 2008.

42. ENDLER-SCHUCK, C. et al. Nanoscale Gd-Doped CeO(2) Buffer Layer for a High Performance Solid Oxide Fuel Cell. J. Fuel Cell Sci. Tech., v. 8, n. 4, Aug 2011.

43. GONG, Y. et al. Low temperature deposited $(\mathrm{Ce}, \mathrm{Gd}) \mathrm{O}_{(2-\mathrm{x})}$ interlayer for $\mathrm{La}_{(0.6)} \mathrm{Sr}_{(0.4)} \mathrm{Co}_{(0.2)} \mathrm{Fe}_{(0.8)} \mathrm{O}_{(3)}$ cathode based solid oxide fuel cell. J. Power Sources, v. 196, n. 5, p. 2768-2772, Mar 12011.

44. CHEN, Y. et al. Development and Fabrication of a New Concept Planartubular Solid Oxide Fuel Cell (PT-SOFC). Fuel Cells, v. 11, n. 3, p. 451-458, Jun 2011.

45. BEBELIS, S. et al. Electrochemical characterization of perovskite-based SOFC cathodes. J. Appl. Electrochem., v. 37, n. 1, p. 15-20, Jan 2007.

46. GHOSH, S.; DASGUPTA, S. Synthesis, characterization and properties of nanocrystalline perovskite cathode materials. Mater. Sci-Poland, v. 28, n. 2, p. 427-438, 2010.

47. GONG, W. Q.; GOPALAN, S.; PAL, U. B. Materials system for intermediate-temperature (600-800 degrees C) SOFCs based on doped lanthanum-gallate electrolyte. J. Electrochem. Soc., v. 152, n. 9, p. A1890A1895, 2005.

48. WANG, S. F. et al. Effects of bi-layer La0.6Sr0.4Co0.2Fe 0.8O3-ס-based cathodes on characteristics of intermediate temperature solid oxide fuel cells. J. Power Sources, v. 196, n. 3, p. 977-987, 2011.

49. SEO, E. S. M., et al. Influence of the starting materials on performance of high temperature oxide fuel cells devices. São Carlos: Mater. Res. v. 7, n. 1, p. 215-220, 2004.

50. ATHANASIOU, C. et al. Methane Activation on a $\mathrm{La}_{(0.6)} \mathrm{Sr}_{(0.4)} \mathrm{Co}_{(0.8)} \mathrm{Fe}_{(0.2)} \mathrm{O}_{(3)}$ Perovsksite; Catalytic and Electrocatalytic Results. Ionics, v. 3, n. 1-2, p. 128-133, Jan 1997.

51. ZYDORCZAK, B.; WU, Z.; LI, K. Fabrication of ultrathin $\mathrm{La}_{0.6} \mathrm{Sr}_{0.4} \mathrm{Co}_{0.2} \mathrm{Fe}_{0.8} \mathrm{O}_{3-\delta}$ hollow fibre membranes for oxygen permeation. Chem. Eng. Sci., v. 64, n. 21, p. 4383-4388, 2009. 
52. TAHERI, Z. et al. Oxygen permeation and oxidative coupling of methane in membrane reactor: A new facile synthesis method for selective perovskite catalyst. J. Mol. Catal. A-Chem., v. 286, n. 1-2, p. 79-86, 2008.

53. TAN, X. et al. Oxygen permeation behavior of La0.6Sr0.4Co0.8Fe0.2O3 hollow fibre membranes with highly concentrated $\mathrm{CO} 2$ exposure. J. Membrane Sci., v. 389, p. 216-222, 2012.

54. GUPTA, R. K. et al. Mechanical, electrical and micro-structural properties of $\mathrm{La}_{(0.6)} \mathrm{Sr}_{(0.4)} \mathrm{Co}_{(0.2)} \mathrm{Fe}_{(0.8)} \mathrm{O}_{(3)}$ perovskite-based ceramic foams. J. Phys. $D$ Appl. Phys., v. 41, n. 3, Feb 72008.

55. CAMPBELL, A. B.; FERRALL, J. F.; MINH, N. Q. Solid Oxide Fuel Cell Power System. IECON Proceedings (Industrial Electronics Conference). Roanoke, VA, p. 1580-1584, 2003.

56. SHAO, Z.; ZHOU, W.; ZHU, Z. Advanced synthesis of materials for intermediate-temperature solid oxide fuel cells. Prog. Mater. Sci., v. 57, n. 4, May 2012.

57. SAKITO, Y. et al. Silver infiltrated La0.6Sr0.4Co0.2Fe0.8O3 cathodes for intermediate temperature solid oxide fuel cells. J. Power Sources, v. 182, n. 2, p. 476-481, 2008.

58. ARDIGO, M. R. et al. Interface reactivity study between $\mathrm{La}(0 \mathrm{6}) \mathrm{Sr}(0 \mathrm{4}) \mathrm{Co}(0$ 2) $\mathrm{Fe}(0$ 8)O(3-delta) (LSCF) cathode material and metallic interconnect for fuel cell. J. Power Sources, v. 196, n. 4, p. 2037-2045, Feb 2011.

59. MINH, N. Q. Ceramic fuel cells. J. Am. Ceram. Soc., v. 76, n. 3, p. 563-588, 1993.

60. GIL, V.; TARTAJ, J.; MOURE, C. Chemical and thermomechanical compatibility between neodymium manganites and electrolytes based on ceria. J. Eur. Ceram. Soc., v. 29, n. 9, p. 1763-1770, 2009.

61. SPOOREN, J.; WALTON, R. I. Hydrothermal synthesis of the perovskite manganites $\mathrm{Pr}_{0.5} \mathrm{Sr}_{0.5} \mathrm{MnO}_{3}$ and $\mathrm{Nd}_{0.5} \mathrm{Sr}_{0.5} \mathrm{MnO}_{3}$ and alkali-earth manganese oxides $\mathrm{CaMn}_{2} \mathrm{O}_{4}, 4 \mathrm{H}-\mathrm{SrMnO}_{3}$, and $2 \mathrm{H}-\mathrm{BaMnO}_{3}$. J. Solid State Chem., v. 178, n. 5, p. 1683-1691, 2005.

62. ZAWADZKI, M.; TRAWCZYŃSKI, J. Synthesis, characterization and catalytic performance of LSCF perovskite for VOC combustion. Catal. Today, v. 176, n. 1, p. 449-452, 2011.

63. LIU, Y. et al. Fabrication and characterization of a co-fired $\mathrm{La}_{0.6} \mathrm{Sr}_{0.4} \mathrm{Co}_{0.2} \mathrm{Fe}_{0.8} \mathrm{O}_{3-\delta}$ cathode-supported $\mathrm{Ce}_{0.9} \mathrm{Gd}_{0.1} \mathrm{O}_{1.95}$ thin-film for ITSOFCs. J. Power Sources, v. 164, n. 1, p. 56-64, 2007. 
64. DUTTA, A.; MUKHOPADHYAY, J.; BASU, R. N. Combustion synthesis and characterization of LSCF-based materials as cathode of intermediate temperature solid oxide fuel cells. J. Eur. Ceram. Soc., v. 29, n. 10, p. 20032011, Jul 2009.

65. LAZAR, D. R. R. Avaliação da influência de elementos de terras raras pesadas na microestrutura e nas propriedades mecânicas e elétricas de cerâmicas de zircônia-ítria. Instituto de Pesquisas Energéticas e Nucleares, IPEN-CNEN/SP, Universidade de São Paulo (USP), Tese de Doutorado, São Paulo, 2002.

66. NESARAJ, A. S. Recent developments in solid oxide fuel cell technology A review. J. Sci. Indust. Res., v. 69, n. 3, p. 169-176, 2010.

67. BENTZEN, J. J. et al. Chromium Poisoning of LSM/YSZ and LSCF/CGO Composite Cathodes. Fuel Cells, v. 9, n. 6, p. 823-832, Dec 2009.

68. WANG, Y. D.; LÜ, Z.; WEI, B. High temperature electrical relaxation study of $\mathrm{La}_{0.6} \mathrm{Sr}_{0.4} \mathrm{Co}_{0.2} \mathrm{Fe}_{0.8} \mathrm{O}_{3-\delta}-\mathrm{Ce}_{0.9} \mathrm{Gd}_{0.1} \mathrm{O}_{1.95}$ composite. J. Inorg. Mater., v. 25, n. 6, p. 635-640, 2010.

69. NIELSEN, J.; JACOBSEN, T.; WANDEL, M. Impedance of porous IT-SOFC LSCF:CGO composite cathodes. Electrochim. Acta, v. 56, n. 23, p. 79637974, 2011.

70. ESQUIROL, A.; KILNER, J.; BRANDON, N. Oxygen transport in $\mathrm{La}_{0.6} \mathrm{Sr}_{0.4} \mathrm{Co}_{0.2} \mathrm{Fe}_{0.8} \mathrm{O}_{3 \text {-delta }} / \mathrm{Ce}_{0.8} \mathrm{Ge}_{0.2} \mathrm{O}_{2-x}$ composite cathode for IT-SOFCs. Solid State Ion., v. 175, n. 1-4, p. 63-67, Nov 302004.

71. SIMRICK, N. J. et al. An investigation of the oxygen reduction reaction mechanism of $\mathrm{La}_{0.6} \mathrm{Sr}_{0.4} \mathrm{CO}_{0.2} \mathrm{Fe}_{0.8} \mathrm{O}_{3}$ using patterned thin films. Solid State Ion., v. 206, p. 7-16, 2012.

72. KIROS, Y.; LIU, X. R.; ZHU, B. Cost-effective Perovskite for Intermediate Temperature Solid Oxide Fuel Cells (ITSOFC). J. New Mat. Electr. Sys., v. 4, n. 4, p. 253-258, 2001.

73. CHEN, M. J. et al. Study of pr-doped ceria-based electrolytes for ITSOFC. ECS Transactions, p. 2245-2252, 2007.

74. USSUI, V. Preparação e caracterização de cerâmicas de ZrO2-Y2O3-TiO2 para aplicações em células a combustível do tipo óxido sólido. 2003. Instituto de Pesquisas Energéticas e Nucleares, IPEN-CNEN/SP, Universidade de São Paulo (USP), Tese de Doutorado, São Paulo, 2003.

75. M, B.-R. Interface chemistry in LSM-YSZ composite SOFC cathodes. Solid State Ion., v. 177, n. 19-25, p. 2195-2200, 2006. 
76. SONG, H. S. et al. Compositional influence of LSM-YSZ composite cathodes on improved performance and durability of solid oxide fuel cells. J. Power Sources, v. 187, n. 1, p. 25-31, 2009.

77. SAMSON NESARAJ, A.; AMI RAJ, I.; PATTABIRAMAN, R. Synthesis and characterization of $\mathrm{LaCoO} 3$ based cathode and its chemical compatibility with $\mathrm{CeO} 2$ based electrolytes for intermediate temperature solid oxide fuel cell (ITSOFC). Indian J. Chem. Tech., v. 14, n. 2, p. 154-160, 2007.

78. LENG, Y.; CHAN, S. H.; LIU, Q. Development of LSCF-GDC composite cathodes for low-temperature solid oxide fuel cells with thin film GDC electrolyte. Int. J. Hydrogen Energ., v. 33, n. 14, p. 3808-3817, 2008.

79. GOSTOVIC, D. et al. Three-dimensional reconstruction of porous LSCF cathodes. Electrochem. Solid St. , v. 10, n. 12, p. B214-B217, 2007.

80. NIELSEN, J.; JACOBSEN, T. SOFC cathode/YSZ - Non-stationary TPB effects. Solid State Ion., v. 179, n. 27-32, p. 1314-1319, 2008.

81. GOUVEIA, D. S. Obtenção de pós nanométricos de hidroxiapatita sintetizados com magnésio utilizando ultra-som. Instituto de Pesquisas Energéticas e Nucleares, IPEN-CNEN/SP, Universidade de São Paulo (USP), Tese de Doutorado, São Paulo, 2008.

82. REED, J. S. Principles of ceramics processing. New York: John Wiley \& Sons, 1995.

83. OLIVEIRA, I. R. et al. Dispersão e Empacotamento de Partículas. $1^{\circ}$ Ed. Associação Brasileira de Cerâmica, 2009.

84. BOTELLA, R. M. Reologia de suspensiones cerámicas. Madrid: Consejo Superior de Investigaciones Científicas, 2005.

85. SCHRAMM, G. Reologia e reometria: fundamentos teóricos e práticos. Artiliber Editora Ltda., 2006.

86. Colloidal Ceramic Procesing Of Nano-, Micro-, And Macro-Particulate Systems. Symposium Held At The 105th Annual Meeting Of The American Ceramic Society. Tennessee: American Ceramic Society, p. 148, 2006.

87. KANG, S.-J., L. Sintering: densification, grain growth and microstructure. Oxford: Elsevier, 2004.

88. RICHERSON, D. Modern Ceramic Engineering, properties, processing and use in design. $2^{\circ}$ Ed. Marcel Dekker, 1992. 
89. FUNAHASHI, Y. et al. Microstructure control of cathode Matrices for the cube-type SOFC bundles. In: BANSAL, N. P. (Ed.). Ceram. Eng. Sci. Proc., v.28, p.195-202, 2008.

90. BECKEL, D. et al. LSCF Thin Film Cathodes Deposited by Spray Pyrolysis for Micro-SOFC. Solid Oxide Fuel Cells 10, v.7, p.1139-1145, 2007.

91. DARBANDI, A. J.; HAHN, H. Nanoparticulate cathode thin films with high electrochemical activity for low temperature SOFC applications. Solid State Ion., v. 180, n. 26-27, p. 1379-1387, Oct 192009.

92. BECKEL, D. et al. Spray pyrolysis of $\mathrm{La}_{0.6} \mathrm{Sr}_{0.4} \mathrm{Co}_{0.2} \mathrm{Fe}_{0.8} \mathrm{O}_{3}$-delta thin film cathodes. J. Electroceram., v. 16, n. 3, p. 221-228, May 2006.

93. LIANG, F. et al. High performance solid oxide fuel cells with electrocatalytically enhanced ( $\mathrm{La}, \mathrm{Sr}) \mathrm{MnO} 3$ cathodes: Electrochem. Commun. 11: 1048-1051 p. 2009.

94. HOLTAPPELS, P.; BAGGER, C. Fabrication and performance of advanced multi-layer SOFC cathodes. J. Eur. Ceram. Soc., v. 22, n. 1, p. 41-48, 2002.

95. LEE, S. et al. Interlayer-free nanostructured $\mathrm{La}_{0.58} \mathrm{Sr}_{0.4} \mathrm{Co}_{0.2} \mathrm{Fe}_{0.8} \mathrm{O}_{3-\delta}$ cathode on scandium stabilized zirconia electrolyte for intermediatetemperature solid oxide fuel cells. J. Power Sources, v. 187, n. 1, p. 74-79, 2009.

96. BAE, J.-M.; STEELE, B. C. H. Properties of $\mathrm{La}_{0.6} \mathrm{Sr}_{0.4} \mathrm{Co}_{0.2} \mathrm{Fe}_{0.8} \mathrm{O}_{3-\delta}$ (LSCF) double layer cathodes on gadolinium-doped cerium oxide (CGO) electrolytes: Role of $\mathrm{SiO}_{2}$. Solid State Ion., v. 106, n. 3-4, p. 247-253, 1998.

97. BAQUE, L.; SERQUIS, A. Microstructural characterization of $\mathrm{La}_{0.4} \mathrm{Sr}_{0.6} \mathrm{Co}_{0.8} \mathrm{Fe}_{0.2} \mathrm{O}_{3 \text {-delta }}$ films deposited by dip coating. Applied Surface Science, v. 254, n. 1, p. 213-218, Oct 312007.

98. BEBELIS, S. et al. Cyclic voltammetry of $\mathrm{La}_{(0.78)} \mathrm{Sr}_{(0.2)} \mathrm{FeO}_{(3-\text { delta) }}$ and $\mathrm{La}_{(0.78)} \mathrm{Sr}_{(0.2)} \mathrm{Co}_{(0.2)} \mathrm{Fe}_{(0.8)} \mathrm{O}_{(3-\text { delta) }}$ electrodes interfaced to CGO/YSZ. Solid State Ion., v. 179, n. 21-26, p. 1080-1084, Sep 152008.

99. MARINHA, D.; DESSEMOND, L.; DJURADO, E. Electrochemical investigation of oxygen reduction reaction on $\mathrm{La}_{(0.6)} \mathrm{Sr}_{(0.4)} \mathrm{Co}_{(0.2)} \mathrm{Fe}_{(0.8)} \mathrm{O}_{(3-\text { delta) }}$ cathodes deposited by Electrostatic Spray Deposition. J. Power Sources, v. 197, p. 80-87, Jan 12012.

100. Advances in Solid Oxide Fuel Cells VII - A Collection of Papers Presented at the 35th International Conference on Advanced Ceramics and Composites, ICACC. Ceramic Engineering and Science Proceedings, 2011. 
101. SCHÜLLER, E.; VABEN, R.; STOVER, D. Thin electrolyte for SOFC via wet powder spraying (WPS): Adv. Eng. Mater. v. 4, 2002.

102. JIN, H. et al. Synthesis and conductivity of cerium oxide nanoparticles. Mater. Lett., v. 64, n. 11, p. 1254-1256, 2010.

103. NOMURA, H. et al. Fabrication of YSZ electrolyte using electrostatic spray deposition (ESD):I - A comprehensive parametric study. J. Appl. Electrochem., v. 35, n. 1, p. 61-67, 2005.

104. VARGAS, R. A. Síntese e caracterização de manganito de neodímio dopado com estrôncio utilizado como catodo em células a combustível de óxido sólido de temperatura intermediária. Instituto de Pesquisas Energéticas e Nucleares, IPEN-CNEN/SP, Universidade de São Paulo, Dissertação de Mestrado, São Paulo, 2007.

105. PRADO, T. C. et al. Metrologia aplicada nas análises de carbono e enxofre em aços de interesse nuclear. Curitiba: III Congresso Latino Americano de Metrologia, 2002.

106. EWING, G. W. Métodos instrumentais de análise química. São Paulo: Edgard Blucher. 1ํㅡd., 1972.

107. ALLEN, T. Particle size measurement. London: Chapman \& Hall, 1968.

108. Corporation., B. I. Instrunction Manual for BI-MAS - ZetaPlus, 1995.

109. BRUNAUER, S.; EMMETT, P. H.; TELLER, E. Adsorption of gases in multimolecular layers: J. Am. Chem. Soc. v. 60, p. 309-319, 1938.

110. WEBB, P. A.; ORR, C. Analytical methods in fine particle technology. USA: Micromeritics Instrument Corporation, 1997.

111. ALLEN, T. Surface area and pore size determination, particle size measurement. London: Chapman \& Hall. ํㅡ. Ed., 1997.

112. RICCI, D. R.; AMBRÓZIO FILHO, F. Caracterização de pós utilizando-se métodos de determinação de tamanho médio de partículas. Cerâmica. v. 30, p. 337-346, 1984.

113. Instruction Manual Multivolume Pycnometer Micromeritics 1305, 1987.

114. GOLDSTEIN, J. I. Scanning electron microscopy and $x$-ray microanalysis. $2^{\circ}$ Ed. New York: Plenum Press, 1992.

115. KESTENBACH, H. J.; TRD. BOTTA FILHO, W. J. Microscopia eletrônica: Transmissão e Varredura. São Paulo: ABM, 1989. 
116. CULLITY, B. D. Elements of x-ray diffraction. $2^{\circ}$ Ed. Massachusetts: Addison-Wesley Publishing Company, 1978.

117. CORRÊA, H. P. S. Análise do $\mathrm{LaCrO}_{3}$ dopados com Sr e Co, preparado via reação de combustão, utilizando difração de raios $X$ com aplicação do método de Rietveld. Universidade Estadual Paulista (UNESP), Tese de Doutorado, Araraquara, 2007.

118. ACCHAR, W. Materiais cerâmicos - caracterização e aplicações. Natal: Universidade Federal do Rio Grande do Norte (UFRN), 2006.

119. MACDONALD, J. R.; BARSOUKOV, E. Impedance Spectroscopy - theory, experiment, and applications. New Jersey: Wiley Interscience, 2005.

120. FANCIO, E. Aplicação do método de Rietveld para análise quantitativa das fases dos polimorfos da zircônia por difração de raios $X$. Instituto de Pesquisas Energéticas e Nucleares, IPEN-CNEN/SP, Universidade de São Paulo (USP), Tese de Doutorado, São Paulo, 1999.

121. DING, J. et al. Slip casting combined with colloidal spray coating in fabrication of tubular anode-supported solid oxide fuel cells. J. Eur. Ceram. Soc., v. 28, n. 16, p. 3113-3117, 2008.

122. BAYTHOUN, M. S. G.; SALE, F. R. Production of strontium-substituted lanthanum manganite perovskite powder by the amorphous citrate techinique: J. Mater. Sci. v. 17, p. 2757-2769, 1982.

123. GAUDON, M. et al. Preparation and characterization of $\mathrm{La}_{1-\mathrm{x}} \mathrm{Sr}_{x} \mathrm{MnO}_{3-\delta}$ $(0 \leqslant x \leqslant 0.6)$ powder by sol-gel processing. Solid State Sci., v. 4, n. 1, p. 125133, 2002.

124. KAKADE, M. B.; RAMANATHAN, S.; DAS, D. Gel-combustion, characterization and processing of porous Ni-YSZ cermet for anodes of solid oxide fuel cells (SOFCs). Ceram. Int., v. 37, n. 1, p. 195-200, 2011.

125. DRUCE, J. W. Mixed conducting CGO-LSCF Composites for Oxygen Separation in Oxyfuelled Carbon Capture and Storgage Systems. Thesis (Ph.D.) Imperial College, London, 2010.

126. BOUKAMP, B. A. et al. The impedance of thin dense oxide cathodes. Solid State Ion., v. 192, n. 1, p. 404-408, 2011.

127. SAHU, A. K.; GHOSH, A.; SURI, A. K. Characterization of porous lanthanum strountium manganite (LSM) and development of ytria stabilized zirconia (YSZ) coating: Ceram. Int. v. 35, p. 803-811, 2009. 